
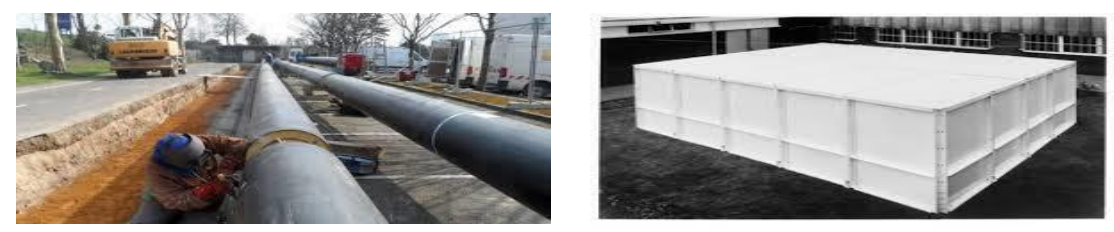

UNIVERSITAT POLITÈCNICA DE VALÈNCIA

HYDRAULIC ENGINEERING AND ENVIRONMENT DEPARTMENT

PhD PROGRAM IN WATER ENGINEERING AND ENVIRONMENT

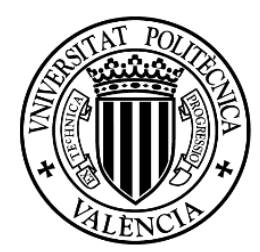

PhD THESIS

Urban drainage network rehabilitation considering storm tank installation and pipe substitution

AUTHOR

ULRICH AURÈLE NGAMALIEU NENGOUE

DIRECTORS

Dr. PEDRO L. IGLESIAS REY

Dr. F. JAVIER MARTÍNEZ SOLANO

September 2019, Valencia, Spain. 


\section{Dedication}

This PhD thesis is dedicated to these special people for me:

Touatcheu Nengoue Victorine

Ndoma Nouagay Doris

Tchamatou Ngamalieu Angela Yovana 


\section{Acknowledgments}

The present PhD thesis has been achieved by the guidance of Dr. Pedro Luis Iglesias and Dr. Francisco Javier Martínez. I would like to thank them for their academic and administrative support during the development of this PhD thesis.

I would like to thank Dr. Daniel Mora Melia for his academic and logistic support during the achievement of this $P h D$ thesis.

I would like to thank my mother Mrs. Touatcheu Nengoue Victorine for her psychologic and financial support for the achievement of this PhD thesis

I would like to thank my fiancée Ms. Doris Ndoma Nouagay for her unconditional support during all the difficult moments i passed through during the development of this PhD thesis.

I would like to thank my daughter Ms. Tchamatou Ngamalieu Angela Yovana for her support during the development of this PhD Thesis. She motivated me to keep going on and always had the funny words to energize me. 
I would like to thank all my family for the advices provided to achieve this PhD Thesis.

I would like to thank Mr. Michel Nouagay and his wife Mrs. Colette Djoupe for their advices and financial support for the achievement of this PhD thesis.

I would like to thank Dr. Stéphanie Signe Mamba, Dr. Amilkar Ilaya Ayza and his wife Wanda for their advices, financial and logistical support for the achievement of this PhD thesis.

I would like to thank Ms. Sandrine Armel Ngaha Ngaha, Ms. Ngueda Christelle and Mrs. Ginette Maguelouk Moffo for their support during the development of this PhD thesis.

I would like also to thank all my friends for their support and motivation during the development of this PhD thesis. Particularly Dr. B. Tchawou, Eric, Nelson, Franklin, Patrick, Erico, Patrice, Falzon, Olivia, Doriane, Gaëlle, Ariane, Maria, Oscar and Sylvaire.

I would like to thank the family Fansi for the advices and the support provided for the achievement of this PhD thesis. Particularly, Papa Tagni and Myriam.

I would like to thank Mr. Jesus Cervera Capella and Mr. Jean Paul Dzokou Newo for their support during the achievement of this PhD thesis.

I would like to thank Mrs. Tapita Ngwaka Eboa, Mr. Sébastien Enoga and Mrs. Edwige Sengo for their support during the development of this PhD thesis.

I would like to thank INGENIOUSWARE GmbH and the Manager Dr. Idel Montalvo Arango for the opportunity offered to spend three months of internship

iv 


\section{Abstract}

Drainage networks rehabilitation is one of the fundamental process that managers and responsible need to implement to adapt defective networks to climate change and urbanization adverse effects. In the literature, pipes substitution or storm tanks (STs) installation are the two scenarios presented by authors. In this thesis, a third scenario proposed combine pipes substitution and STs installation for drainage networks rehabilitation. Results of several simulations on various networks showed that the combine use of pipes substitution and STs installation in drainage networks rehabilitation provides better results than separation of the two rehabilitation scenarios. Unfortunately, such rehabilitation methodologies are computationally time consumers. They need much time to provide acceptable solutions which are often caught up in local minima.

The aim of this thesis is to propose a drainage networks rehabilitation methodology based on the combine use of pipes substitution and STs installation. The methodology considers search space reduction (SSR) technique. The adopted strategy combines in a structured methodology four key options aiming at reducing the search space (SS) of the problem:

- Reduce the number of nodes in which STs could potentially be installed.

- Reduce the number of lines in which there could potentially be a change in diameter

- Reduce the discretization that is made of the section of each of the STs.

- Reduce the number of candidate diameters in the pipes.

Once the search space is reduced, the pseudo genetic algorithm (PGA) used in this thesis for single objective (SO) optimization can easily explore the search space in less time resulting in the obtention of better results. For the MO optimization, the NSGA- 
II can provide rapidly Pareto fronts for the different considered scenarios after the optimization process.

The general objective was divided in specific objectives detailed as follow:

- The first specific objective consists of formulate an optimization problem that verifies that rehabilitation considering STs installation and pipes substitution provides better results than any of the two strategies implemented separately.

- Adequately assess the cost functions used to form the objective functions constitutes the second specific objective. The different costs considered are: Investments costs and flood damage costs.

- The third specific objective is to develop a rehabilitation model considering STs installation and pipes substitution, based on PGA and the Storm Water management Model.

- Investment costs and flood damage costs could not be summed due to their types. Investment costs are reals while, flood damage costs depend on the rainfall probability. So, the fourth specific objective of this thesis is to propose a MOEA for drainage networks rehabilitation considering STs installation and pipes substitution.

- For SO and Multi-objective (MO) optimization, the computation time is elevated. It was also suspected that the objective solutions were caught up in local minima. The fifth objective is to propose an SSR methodology to solve this issue.

- The sixth specific objective consist of carry out a sensitivity analysis to verify the effects of the SSR on the final result of the optimization process. So, different population sizes and stop criteria values were selected and simulation for different configurations were performed.

- The seventh specific objective of this thesis is to propose a new rehabilitation methodology considering SSR technique for MO optimization.

For each specific objective presented in this thesis, an application to a drainage network has been made and the obtained results were satisfactory.

A simple network was used to apply the simple optimization methodology based on PGA algorithm.

A medium size network was used to apply the SO optimization, the MO optimization and the SSR methodology.

Finally, a large and mesh network was used to apply the MO optimization methodology considering SSR proposed in this thesis.

This thesis is endorsed with two communications to congress, two articles presented to journals indexed in the "Journal Citation Reports" database and one article presented to journal indexed in the "Directory of Open Access Journals".

As this is a $\mathrm{PhD}$ thesis dissertation based on a compendium of publications, more indepth information on the content discussed in the main body is available in the publications, which appear as Appendices I, II, III, IV and V. 


\section{Resumen}

La rehabilitación de las redes de drenaje es uno de los procesos fundamentales que los administradores y responsables de la gestión de redes de drenaje deben implementar para adaptar las redes defectuosas a los efectos adversos del cambio climático y la urbanización. Las soluciones tradicionales pasan por la sustitución de tuberías o la instalación de tanques de tormenta (TT). En esta tesis, el escenario propuesto combina la sustitución de tuberías y la instalación de TT para la rehabilitación de redes de drenaje. Los resultados de varias simulaciones en varias redes mostraron que el uso combinado de la sustitución de tuberías y la instalación de TT en la rehabilitación de redes de drenaje proporciona mejores resultados que la separación de los dos escenarios de rehabilitación. Tal metodología de rehabilitación necesita un tiempo de computación elevado para proporcionar soluciones aceptables que a menudo se encuentran atrapados en mínimos locales.

El objetivo de esta tesis es proponer una metodología que permita obtener mejores resultados durante la rehabilitación de redes de drenaje considerando el uso combinado de la sustitución de tuberías y la instalación de TT. La metodología debe considerar la reducción del espacio de búsqueda (SSR).

Cuatro opciones claves están combinadas para lograr reducir el espacio de búsqueda del problema. Estas opciones son:

- Reducir la cantidad de nudos en los que podrían instalarse los TT.

- Reducir el número de líneas en las que podría haber un cambio en el diámetro

- Reducir la discretización que se hace de la sección de cada uno de los TT.

- Reducir el número de diámetros candidatos en las tuberías. 
Una vez que se reduce el espacio de búsqueda, el algoritmo pseudo genético (APG) utilizado en esta tesis para la optimización mono-objetivo puede explorar más partes del espacio de búsqueda en menos tiempo. Lo que resulta es la obtención de mejores resultados. Por la optimización multiobjetivo, el NSGA-II utilizado puede proporcionar frentes de Pareto rápidamente para los diferentes escenarios considerados después del proceso de optimización. continuación:

El objetivo general se dividió en objetivos específicos que se detallan a

- El primer objetivo específico consiste en formular un problema de optimización que verifique que la rehabilitación teniendo en cuenta la instalación de los TT y la sustitución de las tuberías proporciona mejores resultados que cualquiera de las dos estrategias implementadas por separado.

- Evaluar adecuadamente las funciones de costes utilizadas para formar las funciones objetivo constituye el segundo objetivo específico. Los diferentes costes considerados son: costes de sustitución de tuberías, costes de instalación de TT y costes de daños por inundación.

- El tercer objetivo específico es desarrollar un modelo de rehabilitación considerando la instalación de TT y la sustitución de tuberías, basado en APG y el Modelo SWMM.

- Los costes de inversiones y los costes de daños por inundaciones no se pueden sumar debido a sus tipos. Los costes de inversiones son reales mientras que los costes de daños por inundaciones son futuribles, dependen de la probabilidad de ocurrencia de la lluvia. Por lo tanto, el cuarto objetivo específico de esta tesis es proponer un algoritmo multiobjetivo evolucionario para la rehabilitación de redes de drenaje considerando la instalación de TT y la sustitución de tuberías.

- Para la optimización de un mono objetivo y multiobjetivo, el tiempo de cálculo es elevado. También las soluciones objetivas estaban atrapadas en mínimos locales. El quinto objetivo es proponer una metodología de reducción del espacio de búsqueda (SSR) para resolver este problema.

- El sexto objetivo específico consiste en llevar a cabo un análisis de sensibilidad para verificar los efectos del SSR en el resultado final del proceso de optimización. Por lo tanto, se seleccionaron diferentes tamaños de población y valores de criterios de parada y se realizó la simulación para diferentes configuraciones.

- El séptimo objetivo específico de esta tesis es proponer una nueva metodología de rehabilitación considerando la técnica SSR para la optimización multiobjetivo.

Para cada objetivo específico presentado en esta tesis, se realizó una aplicación a varias redes de drenaje y los resultados obtenidos fueron satisfactorios. 
Una red simple fui utilizada para aplicar la metodología de optimización simple basada en el algoritmo PGA y la biblioteca de funciones de conexión con el modelo SWMM.

Una red de tamaño mediano se utilizó para aplicar la metodología SSR. También se ha utilizado para aplicar la metodología de optimización multiobjetivo presentada en esta tesis.

Finalmente, se usó una red mallada de gran tamaño para aplicar la metodología de optimización multiobjetivo que considera el SSR propuesta en esta tesis.

La presente tesis se avala con dos comunicaciones al congreso, dos artículos presentados a revistas indexadas en la base de datos "Journal Citation Reports" y un artículo presentado a revistas indexadas en el "Directory of Open Access Journals".

Dado que se trata de una tesis doctoral basada en un compendio de publicaciones, se ofrece información más detallada sobre el contenido analizado en el cuerpo principal en las publicaciones, que aparecen como Anexos I, II, III, IV y V. 


\section{Resum}

La rehabilitació de les xarxes de drenatge és un dels gestors de processos fonamentals i la necessitat responsable d'implementar per adaptar les xarxes defectuoses als efectes adversos del canvi climàtic i la urbanització. A la literatura, la installació de canonades o substitució de canonades són els dos escenaris presentats pels autors. En aquesta tesi, un tercer escenari proposa combinar la installació de canonades de substitució i tancs de tempesta (TT) per a la rehabilitació de xarxes de drenatge. Els resultats de diverses simulacions a diverses xarxes van mostrar que la combinació d'ús de canvis de substitució de canonades i TT a la rehabilitació de xarxes de drenatge proporciona millors resultats que la separació dels dos escenaris de rehabilitació. Desafortunadament, aquesta metodologia de rehabilitació requereix temps de càlcul elevat per proporcionar solucions acceptables que sovint es troben en mínim local.

L'objectiu d'aquesta tesi és proposar una metodologia que permeti reduir el temps de càlcul i obtenir millors resultats durant la rehabilitació de la xarxa de drenatge considerant l'ús combinat de la instal·lació dels TT de substitució de canonades.

L'estratègia adoptada combina, en una metodologia estructurada, quatre opcions clau per reduir l'espai de cerca del problema:

- Reduir el nombre de nodes en què podrien instal-lar-se els TT.

- Reduir el nombre de línies en què podria haver-hi un canvi de diàmetre

- Reduir la discretització que es fa de la secció de cadascun dels TT.

- Reduir la quantitat de diàmetres candidats à les canonades.

Un cop reduït l'espai de cerca, l'algorisme pseudo-genètic (PGA) que s'utilitza en aquesta tesi per a l'optimització d'un únic objectiu (SO) pot explorar fàcilment l'espai de cerca en menys temps, resultant en obtenir millors resultats. Per a l'optimització del 
MO, la NSGA-II pot proporcionar fronts de Pareto ràpidament per als diferents escenaris considerats després del procés d'optimització.

L'objectiu general es va a dividir en objectius específics detallats a continuació:

- El primer objectiu específic consisteix a formular un problema d'optimització que verifiqui que la rehabilitació considerant la instal-lació de TT i la seva substitució proporciona millors resultats que qualsevol de les dues estratègies implementades per separat.

- Valorar adequadament les funcions de cost que s'utilitzen per formar les funcions objectives, i constitueix el segon objectiu específic. Els diferents costes considerats són: Costes d'inversions i costes de danys a les inundacions.

- El tercer objectiu específic és desenvolupar un model de rehabilitació considerant la instal-lació de TT i la substitució de canonades, basant-se en el PGA i el model SWMM.

- Els costos d'inversions i els costos de danys per inundacions no es poden sumar a causa d'un tipus. Els costes d'inversions són reals mentre els costes d'anuncis per a les futures fonts del futur són dependents de la probabilitat d'obertura de la pluja. Per tant, el cos objectiu específic d'aquesta tesi és propiciar un algorisme multiobjetiu evolutiu per a la rehabilitació de la xarxa de navegació considerant la instal-lació de TT i la substitució de tuberies.

- Per a l'optimització d'un únic objectiu i multi-objectiu, el temps de càlcul s'eleva. També es va sospitar que les solucions objectives eren atrapades en els mínims locals. El cinquè objectiu és proposar una metodologia de la reducció de l'espai de cerca (SSR) per resoldre aquest problema

- El sisè objectiu específic consisteix a realitzar una anàlisi de sensibilitat per verificar els efectes de SSR sobre el resultat final del procés d'optimització. Per tant, es van seleccionar diferents grandàries de població i valors de criteris de parada i es van realitzar simulacions per a diferents configuracions.

- El setè objectiu específic d'aquesta tesi és proposar una nova metodologia de rehabilitació considerant la tècnica SSR per a l'optimització de multi-objectiu. Per a cada objectiu específic presentat en aquesta tesi, s'ha fet una aplicació a una xarxa de drenatge $\mathrm{i}$ els resultats obtinguts han estat satisfactoris.

S'ha utilitzat una xarxa senzilla per aplicar la metodologia d'optimització simple basada en l'algoritme PGA.

Es va utilitzar una xarxa de mida mitjana per aplicar l'optimització del SO, l'optimització del MO i la metodologia SSR.

Finalment, es va utilitzar una xarxa gran i de malla per aplicar la metodologia d'optimització de MO considerant la SSR proposada en aquesta tesi.

Aquesta tesi està avalada per dues comunicacions al congrés, dos articles presentats a revistes indexades a la base de dades "Journal Citation Reports" i un article presentat a la revista indexada al "Directory of Open Access Journals". 
Com que es tracta d'una tesi doctoral basada en un recull de publicacions, es pot trobar informació més detallada sobre els continguts tractats al cos principal a les publicacions, que apareixen com a Annexos I, II, III, IV i V. 


\section{Contents}

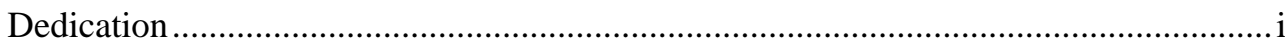

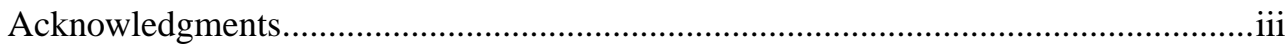

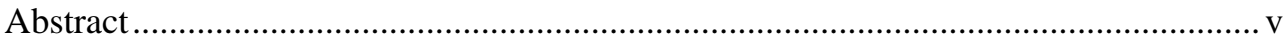

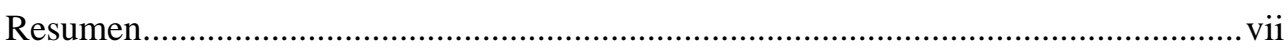

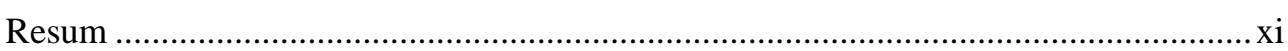

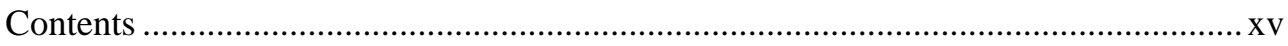

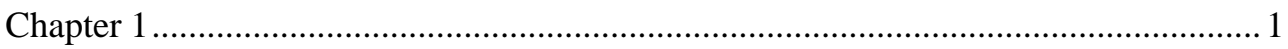

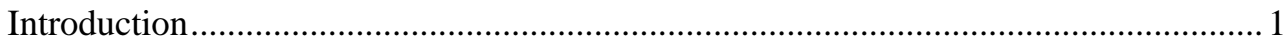

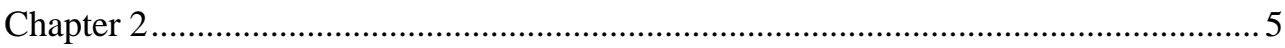

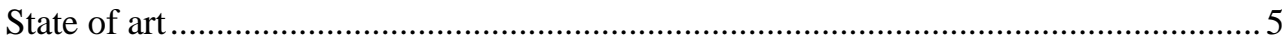

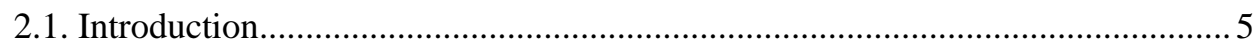

2.2. Drainage networks adaptation.................................................................. 6

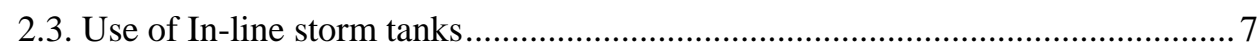

2.4. Single-objective rehabilitation ............................................................... 9

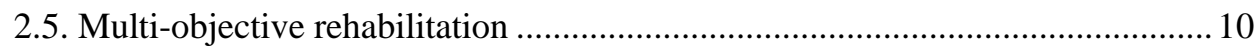

2.6. Search space reduction methodology ..................................................... 11 


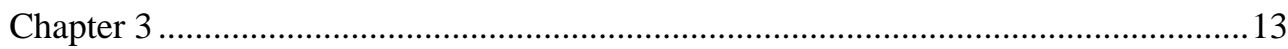

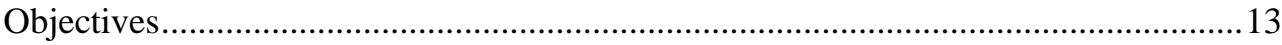

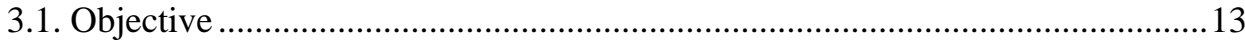

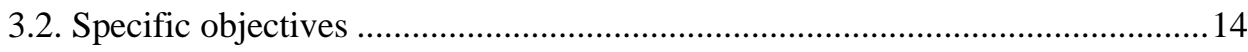

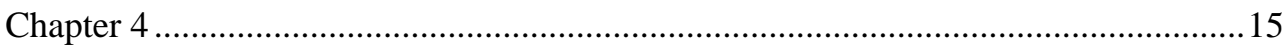

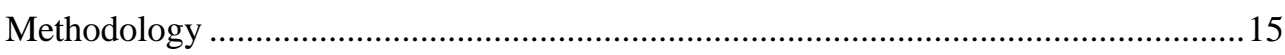

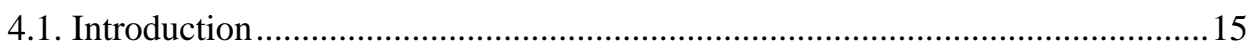

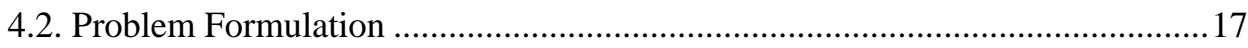

4.2.1. Decision Variables ................................................................................

4.2.2. Cost Functions …………………………………................................ 19

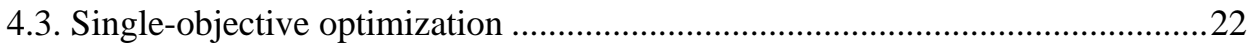

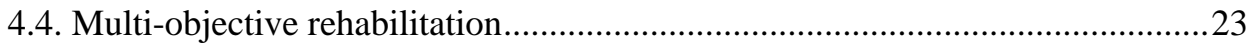

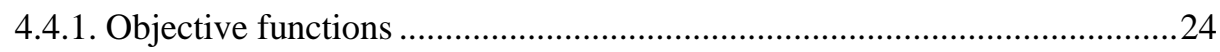

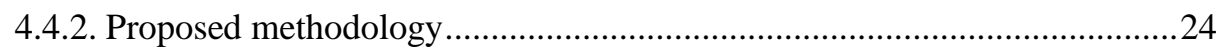

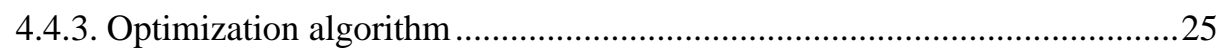

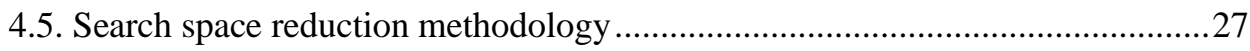

4.6. Methodology proposition for multi-objective optimization .............................. 31

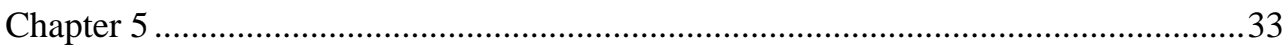

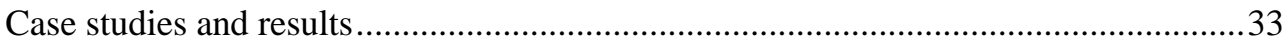

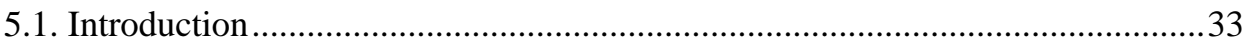

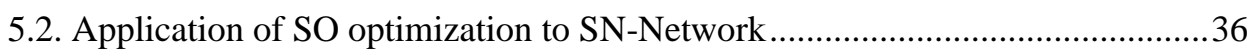

5.3. Application of SO optimization and SSR to E-Chicó. .........................................39

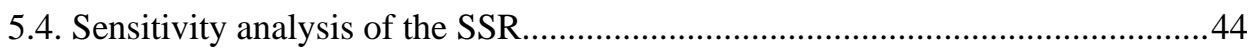

5.5. Application of MO optimization to E-Chicó.......................................................46

5.6. Application of the proposed methodology for $\mathrm{MO}$ optimization .........................48

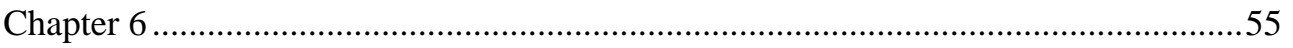

Conclusions and future developments....................................................................5 


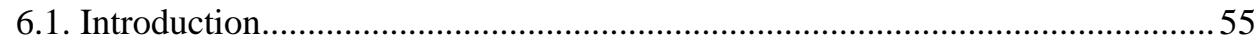

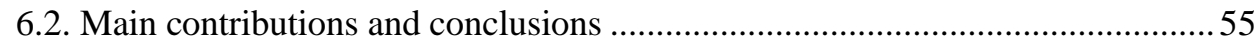

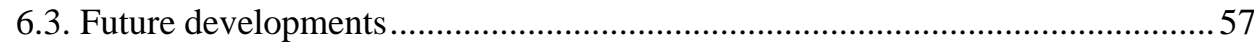

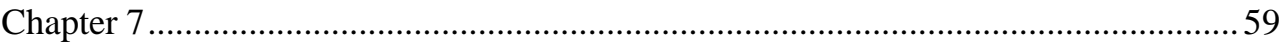

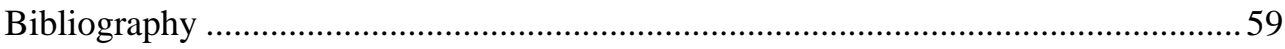

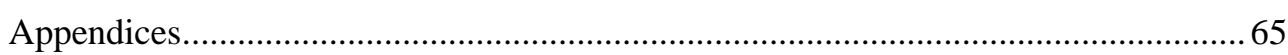

Rehabilitación de redes de drenaje mediante la combinación de tanques de retención y sustitución de conducciones

Desarrollo de una metodología para proyectos de rehabilitación de redes de drenaje pluvial bajo escenarios de cambio climático........................................................... 79

Urban drainage network rehabilitation considering storm tank installation and pipe substitution.

Multi-objective optimization for urban drainage or Sewer networks rehabilitation through pipes substitution and storm tanks installation

Urban drainage networks rehabilitation using multi-objective model and search space reduction methodology 


\section{Chapter 1}

\section{Introduction}

During the last decades, the number and frequency of extreme rainfalls increased considerably. All the parts of the world experienced changes with severe consequences. On one side, there are regions facing the acceleration of drought while on the other side, there are regions coping with flooding. In both cases there are consequences that seldom are fatal to people.

The location of these catastrophic events showed that they occurred in both developing countries, which are not equipped with drainage networks, and in developed countries where drainage networks exist but are insufficient. Among the factors causing these events, two of them stand out: climate change and urbanization. Another outstanding fact is the increase of urbanization in several cities and countries around the world. This process is based on the displacement of people to concentrate on some cities that end up creating the need to build more houses, streets and facilities for the population. The consequence of this growing urbanization is the reduction of soil infiltration capacity and the increase of the runoff volumes caused by the rainfall events. The combination of the two precedent facts (extreme rainfalls and the increase in urbanization and runoff) explains the increase of flooding in some parts of the world.

The mission of a drainage network is to transport the rainwater from the inflow point to the discharge point of the network, passing or not through a water treatment plant. Cities not equipped with drainage networks should build them in an optimal way considering the future variations of rainfall and runoff generated in urban land. On the 
contrary, those cities with drainage networks must improve or rehabilitate their systems to adapt them to the new conditions. Probably the existing networks were designed in a correct way, considering factors such as historical rainfall data, topography of the considered area and the available budget. However, changes in rainfall and runoff processes can cause problems in originally well-designed networks. Drainage networks are designed to work in free surface flow. However, the increase in runoff and water volume may cause them to operate under pressure. The extra water accumulates out of the network and forms floods.

In the literature, there are many studies [1-8] dealing with the adaptation to climate changes and adverse effects of urbanization. There are various methodologies to improve a deficient drainage network and increase its transportation capacity with less impact on the existing structure. The first methodology consists of redesigning the drainage network. This solution is not valid because of the total investment to be made. The second methodology consists of change only a part of the drainage network, i.e. to increase the concentration time and reduce the overflow at the wastewater treatment plant. Zhang et al. [9] proposed to renew some pipes. While, Ugarelli and Di Federico [10] calculated the economic balance between replacing damaged infrastructures or maintaining them for a certain period of time. These two methodologies can be considered as traditional methodologies. A third methodology consists of partially store the water to reduce the conductivity of the network and benefit from the actual capacity of the network. For instance, Sebti et al. [11] developed a model for the optimal selection and placement of structural measures. These structural measures are hydraulic assets used to increase the concentration time of water in the system. They considered four types of structural low impact development (LID) practices: retention pond, green roofs, infiltration tranches and vegetated depressions to minimize the total cost of LIDs. They limited the combined sewer overflow as a constraint.

In this thesis, the proposed methodology considers pipes substitution and storm tanks (STs) installation in some nodes of the network. Therefore, it is necessary to define a hydraulic model of the network on which the methodology will be applied. The SWMM toolkit [12] is used for the hydraulic analysis of the drainage network, while an integer coding genetic algorithm, also known as Pseudo Genetic Algorithm (PGA) [13] is used to optimize the objective function of the problem.

The problem is formulated as an optimization problem where the objective function is the cost associated to the installation of the elements in the network and the damages caused by flooding. Three scenarios are implemented based on the decision variables selected: scenario 1 considers pipes substitution. Scenario 2 considers storm STs installation. Finally, scenario 3 considers the combined use of pipes substitution and STs installation. The objective here is to compare the three scenarios in order to know if the combined use of pipes substitution and STs installation provides better results in terms of objective function values than the two options taken separately.

A single-objective (SO) optimization provides only a best solution for each simulation performed. The costs considered in the objective function are composed of two types of costs: investment and damage costs. Investment costs must be expended to 
adapt the drainage network. In other words, there are known independently of the rainfall event. On the other hand, flood damage costs are dependent on the rainfall probability. For this reason, both type of costs should not be summed. Therefore, a multi objective (MO) optimization algorithm is proposed to harmonize both types of costs and compute conflicting objectives between investment costs and flood damage costs. The MO optimization algorithm is a tool provided to drainage network managers that allows them to prevent floods or reduce them while improving their networks quality service based on their budgets or on their objectives.

Two conflictive objective functions are defined for the MO optimization. These objective functions are optimized for different scenarios. Pareto fronts are drawn to compare results of different scenarios. Pareto fronts also allow to verify if the combined use of pipes substitution and STs installation provides better results than the two strategies implemented separately.

Implementation of the defined scenarios in both single- and multi-objective optimization needs elevated computation time to provide results. These results are caught up in local minima due to the search space (SS) size. Therefore, a search space reduction (SSR) methodology is performed to reduce the problem size and provide to the optimization algorithm more exploration capacity.

The composition of the present thesis is detailed in the following lines. Chapter 2 summarizes the state of the art on the main aspects that mark the starting point of this work such as problems caused by extreme rainfall events, existing rehabilitation methodologies and SSR methodology. Once the state of the art has been analyzed, the main objective of the thesis and the specific objectives derived from the main one are presented in chapter 3.

The methodology proposed to achieve the main objective and the specific objectives of the thesis is presented in chapter 4. Each part of the methodology solves a precise problem encountered and lead to the proposition of a new methodology for drainage network rehabilitation. SO optimization, MO optimization and SSR methodology will be presented. Various case studies are presented for the validation of each part of the methodology in chapter 5. The first drainage network is used to validate the SO optimization methodology based on the PGA algorithm. The second drainage network is used to validate the SSR methodology and the NSGA-II [14] methodology, and the third drainage network is used to validate the proposed methodology in this thesis. All the results obtained by the application of each methodology to a specific drainage network are discussed. The contributions of this thesis to the state of art of drainage networks rehabilitation are presented in chapter 6 . The conclusions obtained after the application of the proposed methodology to various drainage networks are formulated. Some future developments are also presented in chapter 6.

This $\mathrm{PhD}$ thesis is presented under the process "Compendium of articles". In accordance with the Spanish regulation (Real Decreto 99/2011 28/01/2017), which regulates the official doctoral studies. Therefore, the five publications that support the development of this thesis are attached to the present memory: 
- Ngamalieu, U., Iglesias-Rey, P. L., Martinez-Solano, F. J., \& Saldarriaga, J. Rehabilitation of Drainage Networks through the Combination of Retention Tanks and Replacement of Pipelines. SSRN Electronic Journal 2017. http://doi.org/10.2139/ssrn.3113706. (Appendix I).

- Ngamalieu-Nengoue, Ulrich Aurèle; Iglesias-Rey, Pedro L.; Martinez-Solano, F. Javier; Saldarriaga-Valderrama, Juan G.; Mora-Melia, Daniel. Development of a Methodology for Drainage Networks Rehabilitation Projects under Climate Change Scenarios. 22nd International Congress on Project Management and Engineering Madrid, 11th - 13th July 2018. PP. 659 - 671. ISBN: 978-84-0905132-8. (Appendix II).

- Ngamalieu-Nengoue, U.A.; Iglesias-Rey, P.L.; Martínez-Solano, F.J.; MoraMeliá, D.; Saldarriaga Valderrama, J.G. Urban Drainage Network Rehabilitation Considering Storm Tank Installation and Pipe Substitution. Water 2019, vol. 11, no. 3, pp. 515. https://doi.org/10.3390/w11030515. (Appendix III).

- Ngamalieu-Nengoue, U.A.; Martínez-Solano, F.J.; Iglesias-Rey, P.L.; MoraMeliá, D. Multi-Objective Optimization for Urban Drainage or Sewer Networks Rehabilitation through Pipes Substitution and Storage tanks installation. Water 2019, vol. 11, no. 5, pp. 935. https://doi.org/10.3390/w11050935. (Appendix IV).

- Ngamalieu-Nengoue, U.A.; Iglesias-Rey, P.L.; Martínez-Solano, F.J. Urban Drainage Networks Rehabilitation using Multi-Objective Model and Search Space Reduction Methodology. Infrastructures 2019, vol. 4, no. 2, pp. 35. https://doi.org/10.3390/infrastructures4020035. (Appendix V). 


\section{Chapter 2}

\section{State of art}

\subsection{Introduction}

One of the main problems related to urban drainage systems are the frequent flooding events in urban areas. Mailhot and Duchesne [15] suggested that the probability of occurrence of intense rainfall will increase in a future because of greenhouse gas emissions. Gulizia and Camilloni [16] made a comparison among different global climate model applied to South America. These models showed that an increase of up to $36 \%$ in rainfall events is expected in that region. Climate change undoubtedly affects the intensity and frequency of meteorological phenomena, including a gradual increase in rainfall intensities in many cities throughout the world. This induces increased runoff flow, making systems initially well designed begin to fail. This was confirmed by Jeong et al. [2] who said that if a rainfall event is higher than infrastructure facilities capacity, their neighboring assets will be damaged, and this will provoke a flood. According to Quinn et al. [17], extreme events cause damages to public usage infrastructures. Not only infrastructures are damaged by extreme rainfalls, Ma et al. [18] studied flash flood effects and frequencies in China. They arrived to the conclusion that flash floods are still the main cause of deaths in flood disasters.

This situation is becoming alarming since it can be expected that urban drainage networks designed for past conditions will not function as effectively in the future as they do now [1]. Beside extreme rainfall events, urbanization can cause adverse effects 
such as the reduction of soils infiltration capacity. In order to have a better control over the systems and prevent the occurrence of urban flooding events, many mechanisms have been implemented to reduce runoff and increase the capacity of the system. Some of these mechanisms are detailed in the following sections.

\subsection{Drainage networks adaptation}

The aim of rehabilitation is to improve drainage network quality service and especially adapt it to new conditions imposed by extreme rainfalls. Thereby, several methods have been developed and applied for this purpose. On one hand, there are traditional engineering methods consisting in pipe replacement. On the other hand, there are modern techniques of engineering consisting in the installation in the network of hydraulic retention elements. The purpose is to increase the water time of concentration in the network or store it during peak flow in order to reintroduce that water when the rainfall is finished avoiding overflows on the receiving water bodies.

During years, several studies considering pipes replacement have been carried out to achieve optimal rehabilitation of defective drainage networks in order to prevent floods and environmental threats while minimizing the investment costs. Driessen et al. [19] defined five different complementary approaches to improve the resilience of hydraulic infrastructures: prevention, defense, mitigation, preparation and recovery. Among these strategies, the most traditional one is the flood defense, based on the idea of "keep water away from people". Abraham et al. [20] proposed an integrated management methodology considering Markovian probability-based models combined with deterministic models to predict structural failures of sewer networks. Based on these models, they proposed a priority rehabilitation plan based on the available budget. The methodology discretizes the network in small systems which are identified based on their structural characteristics. Although these methods are efficient, new methodologies are investigated in order to replace them.

During last decades, a new trend in drainage networks rehabilitation has been developed and implemented: the LID practices. De Paola et al. [4] implemented a decision support system on two cases studies using Storm Water Management Model (SWMM) [21] as hydraulic analysis tool and Harmony Search as optimization method. The aim of their study was the reduction of flooding volume while minimizing the investment costs. The proposed strategy of De Paola et al. started with territorial analysis in Geographical Information System (GIS). Then, a setting of the network was made and finally the optimization was performed. In the context of extreme rainfalls, the model proposed by De Paola et al. can select and implement adequate LID practices to reduce floods and ensure minimal investment. Martínez et al. [22] proposed a framework aiming to select and install a green infrastructure. Bio-retention cells, infiltration trenches, porous pavement and vegetation swales were the available options. The main objective of their study was urban runoff reduction, improvement of water quality while reducing investment costs. Gong et al. [23] studied the effects of various parameters on the green 
roof runoff retention capacity for several rainfall events and 10 extensive green roof modules. Their results showed that green roofs were effectives for rainfall events of low to moderate intensity and were affected negatively by extreme rainfall events. Mora et al. [24] also obtained results showing limits of LID practices use. So, there was a necessity to find a better hydraulic asset to overcome this problem. ST is the asset proposed to overcome the problem posed by LID practices.

\subsection{Use of In-line storm tanks}

STs are hydraulic elements that are installed in drainages networks to increase the concentration time of water in the system. In drainage network, STs are installed as In-line or as Off-line. An In-line ST is in serial with other elements of the network. An Off-line ST is built near of the network and is connected to the network by a conduit. Generally, control elements are used to regulate its functioning.

Investigations carried out on the use of STs in drainage networks showed that there are two approaches: studies without simulations and studies with simulations. Studies without simulations are studies where hydraulic simulations of the network behavior were not performed. While studies with simulations are studies supported by hydraulic simulations of the network behavior.

\subsubsection{Use of Storm tanks without hydraulic simulation of the network}

Howard [25] published one of the first works related to storm tanks where it is established that the effectiveness of the STs combined with Wastewater Treatment Plants to control runoff depends on STs and WTP's capacity as well as the duration and volume of the precipitation events they must control. The work of Howard also lays out the possibility of using computational tools for the analysis of these devices, but his work was focused on the usage of probabilistic methods based on precipitation data. Di Toro and Small [26] posited a statistical method based on a probabilistic characterization of both rainwater and runoff that predicts the behavior of the storm water control devices. The long-term behavior of a ST is determined based on its size, operation method and both runoff and precipitation statistical characteristics. Based on them, Di Toro and Small studied the filling, storage and emptying of the retaining structures; flow variations caused by storm water; and first flush's implications regarding water quality.

Early ST sizing methods were based on roughly simplified methods since simulation techniques require a high computational effort in terms of time and memory. Loganathan et al. [27] presented a simplified method that could estimate ST capacity considering previous storms. This method is based on exponential probability density functions for the main hydrological variables involved (runoff volumes, runoff duration, time between events). These functions are used to generate a new statistical distribution that can estimate WTP's capacity and retention volume for a given risk level. One of the 
main advantages of this method is that it permits us to determine the preliminary volume for an ST. With the same focus, Meredith et al. [28] developed a procedure based on all available historical data for the dimension of a runoff storage structure. The sizing process uses the water quality concept because all runoff must pass through the cleaning water process in the WTP. The method was tested in several industrial areas, but it was limited to small areas where rational methods could be applied.

Most of these studies were focused on the treatment of rainwater runoff before the water enters the network. Due to urban area space restrictions, alternative systems for the treatment of runoff water are needed. To cope with this objective, Takamatsu et al. [29] presented the design of a rainwater storage system as part of the complementary structure of road drainage. They developed a mathematical model based on the hydraulic principals to estimate the efficiency of the pollutant elimination. The main idea was to evaluate the efficiency of a rectangular runoff ST removing suspended solids. In order to validate the mathematical model, a scaled (1/5) network model was built, on which several tests were run to study the influence of different inflows, functioning frequency and pollutant concentrations. The temporal concentration of suspended solids at the exit and the efficiency of the conceptual model were compared. They concluded that there is a correlation between the detention time and the removal efficiency.

All the methods presented in this section did not use a hydraulic simulation of the network behavior. Therefore, in the next section some studies supported by hydraulic simulation of the network behavior are presented.

\subsubsection{Use of Storm tanks with hydraulic simulations of the network}

In the precedent section, some studies of STs implementation without hydraulic simulation were presented. In this section, some studies of STs implementation supported by the hydraulic simulation of the drainage network are presented.

De Martino et al. [30] proposed the usage of STs as structures controlling the impact of the first-rain contamination, which has the highest pollutant load. As the design of this system depends on a large number of parameters, they considered that the design is not completely defined because, they used only some of the required parameters. In order to study the influence that the rainwater might have, De Martino et al. made several simulations with different rainfall-time series in Campania (Italy). They obtained the pollution load removal rate allowing them to estimate the effectiveness and the capacity of STs to reduce pollution in receiving water. Butler and Schütze [31] developed a model (SYNOPSIS) consisting of a series of sub-models of the sewage network, the treatment plant and the behavior of the natural stream over which the evacuation of the system will be made. These sub-models, together with a developed control module, allow the development of water control strategies in order to minimize the impact on the water drainage. Fu et al. [32] extended the work of Butler and Schütze taking into account the optimal rehabilitation of urban wastewaters as a multi-objective problem. For this, they used the non-dominated sorting genetic algorithm (NSGA-II) [14] that allows obtaining Pareto fronts for several optimal solutions. 
Most of the previous works about the usage of STs are focused on the issue of maximizing the quality of poured water, not to control the potential overflows that may occur due to excessive rainwater. However, some studies have been carried out in order to show that STs can also reduce floods. One of the first studies that use STs with the rainwater variation due to climate change was done by Andrés-Domenech et al. [33]. Their study focused on the effects originating from changes in the rainfall regimes on the efficiency of the actual drainage systems. They arrived to the conclusion that the filtering effect operated by the urban catchment can mitigate the effects of climate variability on STs efficiency. Wang et al. [34] proposed a two-stage optimization framework to find an optimal scheme for STs using SWMM. As a result, the authors conclude that the use of STs not only reduces flooding, but also the total suspended solids. Cunha et al. [35] showed that the location, dimensions and flow control capabilities of storage tanks strongly affect their efficiency. In the work of Cunha et al., only STs were used as a strategy for flood reduction. Simulated Annealing was used as the optimization model. Tao et al. [36] combined SWMM and NGSA-II to calculate the size of decentralized STs. The objective of their study was to propose a methodology for STs design and planning. The methodology should achieve peak flow reduction, flood control and investment costs reduction. A similar work was made by Li et al. [37] combined SWMM and Non-dominated sorting Particle Swam Optimization for the optimal design of STs in a drainage network. They proposed a cost-effective methodology for drainage networks rehabilitation. The objective of their work was to minimize investments costs while reducing flooding risk.

It appears that use only STs is not the adequate solution. Therefore, it should be combined to pipes substitution. To obtain good solutions, it will be necessary to perform an optimization. This will be explained in next chapter.

\subsection{Single-objective rehabilitation}

A rehabilitation process can be addressed whether as single-objective or multiobjective optimization, based on the objectives to achieve. There are various optimization algorithms used to perform a SO optimization, such as Genetic Algorithm, Particles Swarm Optimization and many other. In this section some SO optimization works are presented. Reyna et al. [38] proposed some solutions to the challenges met in the process of finding new strategies for sewer networks rehabilitation methodologies allowing to maintain the cost-effectiveness. They presented in a state of art the available methodologies of drainage network optimal rehabilitation. For their part, Gaudio et al. [39] proposed a combined methodology for the hydraulic rehabilitation of urban drainage networks. Against the traditional statements of rational method, they concluded that not only intensities, but also rainfall volume conditioned the hydraulic design. Gaudio et al. combined observed rainfall data and synthetic hyetographs to deduce the hydraulic critical conditions in terms of overflow volumes rather than rainfall volumes. 
While Abraham et al. [20] proposed a methodology for drainage networks rehabilitation based on priority plan. Sebti et al. [40] proposed an optimization methodology for selection and placement of LID. They considered both infrequent and frequent rainfalls. The objective was to reduce the investment cost for adequate LID installation. Another work also considering installation of LID was carried out by Karamouz et al. [41]. They developed a methodology for drainage networks rehabilitation taking into account climate change effects. The objective of their methodology was the selection of adequate LID practice and reduction of investments. To achieve their objective, Karamouz et al. combined the Soil Water Assessment Tool (SWAT) and a Genetic Algorithm for the optimization of their solution. A case study was carried out by $\mathrm{Xu}$ et al. [42]. They proposed a rehabilitation methodology to improve the capacity of drainage networks in the city of Fuzhou, China. Their methodology considered climate change and adopted an installation of storage facilities and pump based on a certain period of time. All these single-objective optimization works aimed to reduce the investment costs.

There are other works whose objective was the improvement of the network. Ouellet and Duchesne [43] proposed a methodology for drainage network pipes rehabilitation. The methodology considered data of past replacement in the statistical modelling of their deterioration. Decisions were made on the base of aging of pipes and replacement probabilities of pipes.

SO optimization provides only a solution. In real world, problems encountered present conflictive objectives. Therefore, it is important to introduce MO optimization that can handle several objectives and propose a set of solutions.

\subsection{Multi-objective rehabilitation}

Optimization is necessary to obtain good results of simple or complex problems. MO optimization is one of the indicated options to implement. In practice, drainage networks rehabilitation sometimes presents conflicting objectives. The precedent sections of this state of art shown that there are various ways to plan the rehabilitation of drainage networks. There are also different objectives to achieve. To solve all these conflictive objectives, it is necessary to used MO optimization algorithms. There are various MO optimization algorithms. Deb [14] introduced the NSGA-II which was converted into the one of the most famous in MO problem optimization. Some interesting works implementing a multi-objective optimization methodology are presented. For the rehabilitation of drainage networks, Barreto et al. [44] proposed a MO optimization methodology. The main objective was help decision makers in the management of their networks. Conflicting interests such as rehabilitation costs, flood damage and risk were considered. Pareto fronts were drawn for investment costs against damage costs. They also made a comparison between NSGA-II and $\varepsilon$-MOEA. Some results of their comparison are: NSGA-II has higher performance when the population size is small. $\varepsilon-$ MOEA is less sensitive to the population size. The diversity of the set of solutions proposed by $\varepsilon-$ MOEA is not as good as that of NSGA-II. Results obtained by Barreto et 
al. suggest that NSGA-II is an effective algorithm for MO optimization. Vojinovic et al. [45] proposed a multi-objective approach for drainage network rehabilitation. Vojinovic et al. used SWMM to simulate the hydraulic behavior of the network. Latin Hypercube Sampling was used to sample statistical distribution and uncertainty while NSGA-II was applied to optimize their solutions. Lim et al. [46] presented a MO rehabilitation of a drainage network. Their approach considered the installation of detention facilities and the optimization of their locations and capacity by a multi-objective genetic algorithm. The aim was the total overflow reduction while minimizing the investment. Their methodology will be helpful for managers in the effective selection and installation of retention assets in drainage networks. They used total flow to characterize floods and they did not consider pipes substitution in their study.

Due to the complexity of drainage network, it is necessary to optimize the control to make it easy. Beraud et al. [47] proposed then a MO optimization of control strategies. This control should be implemented to achieve the operational objectives of drainage networks. For their study, Beraud et al. combined NSGA-II with the network simulation tools MOUSE and Infoworks CS. To prevent structural failures, Yazdi [48] proposed an optimal methodology for drainage networks rehabilitation and flooding mitigation, considering effects of unexpected structural failures during rainfall events. To achieve this, he connected SWMM to non-dominated sorting differential evolution (NSDE) to track the set of optimal solutions. Paredes et al. [49] developed a framework for urban drainage network systems assessment. They combined SWMM that allows to simulate the overload flow on nodes and NSGA-II to find a set of optimal solutions for the MO rehabilitation process. Pareto fronts were drawn for rehabilitation costs against flood risk costs for several rainfall return period. Yazdi et al. [50] proposed a MO rehabilitation methodology for urban drainage networks. They linked their optimizer named non-dominated sorting harmony search (NSHS) to SWMM that simulates overflow generated in network nodes. Rainfall uncertainties was investigated by Monte Carlo simulation. One of the major inconvenient of the $\mathrm{MO}$ optimization is that it needs elevated calculation time to find the set of optimal solutions.

MO optimization is one of the best options to rehabilitate drainage networks. However, due to the elevated number of decision variables (DVs), the vast SS and the elevated number of local minima, it is important to consider the reduction of the problem size. This could increase the exploration capacity of the optimization algorithm. In the next section SSR will be introduced.

\subsection{Search space reduction methodology}

A new challenge in the optimization of water resources management is the reduction of the computation time and the obtention of better results. To achieve this, the reduction of search space could help the optimization algorithm to find the optimal solution by providing it a better exploration capacity. There are not many studies in this 
field but, Maier et al. [51] presented the new challenges such as reduction of computation time and SSR and applied them to water resources management. While Sophocleous et al. [52] proposed the SSR to the leak localization in real water distribution. The SSR proposed considers 3 steps. They consider in the first step that leak only happen on pipes. So, they exclude all nodes not associated to pipes. In the second step, boundary conditions for leak-free scenario are imposed and resulting pressure at nodes are analyzed. Simulations are performed and the pressure residuals between a no-leak and leak scenario are determined for all possible leak nodes across all the simulation time steps. In the third step, the final search domain for detecting and localizing leaks is established. In this thesis an SSR methodology is proposed and will be detailed in chapter 4.

In both single- and multi-objective optimization the solution of the optimization problem requires an elevated number of DVs generating a large space of feasible and unfeasible solutions. This SS entails not only a big computational effort, but also may cause the method to fall at local minima, limiting the ability to find the best solution. A reduction in the size of the problem and, subsequently, in the size of the SS might help the convergence of the method.

In this thesis, the main objective is to propose an optimal rehabilitation methodology for drainage networks that considers SSR. This objective is presented in detail in the next chapter. 


\section{Chapter 3}

\section{Objectives}

\subsection{Objective}

Drainage networks are important infrastructures for the daily life of a city. Their main problem are the failures they experiment with time due to structural defections, climate change and urbanization adverse effects. Therefore, it is necessary to rehabilitate them to improve their quality service. Pipes substitution or STs installation are strategies proposed to improve drainage networks. However, the combine use of STs installation and pipes substitution is proposed in this thesis as a methodology to rehabilitate urban drainage networks. First results obtained as part of this thesis showed that the combine use of pipes substitution and STs installation for drainage networks rehabilitation gives better results, in term of objective function value than the separate use of pipes substitution or the installation of STs for the same operation. In term of computation time, the combine use of pipes substitution and STs installation takes much longer time to provide results. After a certain number of simulations, the objective function value reached a lower threshold. So, a question emerged and was: Is it possible to find a method allowing the rehabilitation of drainage networks combining the use of pipes substitution 
and STs installation using less computation time and providing a better value of objective function?

The main objective of this investigation work is the development of a new methodology for urban drainage networks rehabilitation. This methodology will consider STs installation and pipes substitution. It will be computationally improved by developing an SSR technique. This main objective is divided into the following specific objectives.

\subsection{Specific objectives}

The first specific objective consists of formulate an optimization problem that verifies that rehabilitation considering STs installation and pipes substitution provides better results than any of the two strategies implemented separately.

Adequately assess the cost functions used to form the objective functions constitutes the second specific objective. The different costs considered are: Pipes substitution investment costs, STs installation investment costs and flood damage costs.

The third specific objective is to develop a rehabilitation model considering STs installation and pipes substitution, based on PGA and SWMM.

The fourth specific objective of this thesis is to propose a MO optimization algorithm for drainage networks rehabilitation considering both STs installation and pipes substitution.

The fifth objective is to propose an SSR methodology to reduce the problem size. The SSR uses two strategies: The reduction of DVs and the reduction of variation range of this DVs.

The sixth specific objective consists in carry out a sensitivity analysis to verify the effects of the SSR on the final result of the optimization process. So, different population sizes and stopping criteria were selected and simulation for different configurations were performed.

The seventh specific objective of this thesis is to propose a new rehabilitation methodology considering SSR technique for MO optimization. 


\section{Chapter 4}

\section{Methodology}

\subsection{Introduction}

Drainage networks designed for cities throughout the world have the mission to evacuate water of rainfall. In the case of occurrence of extreme rainfall events, the capacity of the drainage network can be exceeded. The extra water accumulates out of the network and forms floods.

The insufficiency of drainage networks raises the question of actions that should be taken to improve the networks quality of service. Several strategies can be used to adapt drainage networks to increasing runoff volumes. In this thesis, pipes renewal and STs installation are the strategies adopted to improve insufficient drainage networks.

Some starting hypotheses established in this work are presented as follow:

- The drainage system models must go through a calibration process, since the analysis must be as accurate as possible. That is, the starting point of the process is a calibrated hydraulic model of the drainage network. Traditionally, this type of simulation is performed considering uniform flow. However, in this case, each configuration is analyzed using the dynamic wave model, because it provides a better representation of floods than the kinetic wave model or uniform model. 
- It is necessary to have a hydraulic model of the drainage network for the most unfavorable design rainfall.

- The hydraulic analysis can consume much time. Therefore, if it is possible, it is necessary to simplify the network model. The accuracy of the result must not be compromised. This simplification will highly reduce computational times for every hydraulic simulation.

- The STs are single chamber, in-line tanks without control devices. The invert elevations of the tanks are assumed to be the same as the one of nodes where they will be installed. The connection invert elevations of the STs are also assumed to be the same as the one of the nodes. This can be observed on Figure 1.

- The optimization problem will be addressed in monetary units. Thus, the first step would be to find the cost functions that characterize the value of hydraulic variables in monetary units. So, the functions that together form the optimization total cost problem are: pipes replacement cost, ST installation cost and total flood damage cost.

- In this work, floods are characterized by the maximum depth reached by water. Damages caused by flood are represented by flood damage cost.

From all described mathematical approaches, it seems heuristics approaches can give the best advantages for the process. Therefore, based on previous satisfactory experience [13], a PGA method was used.

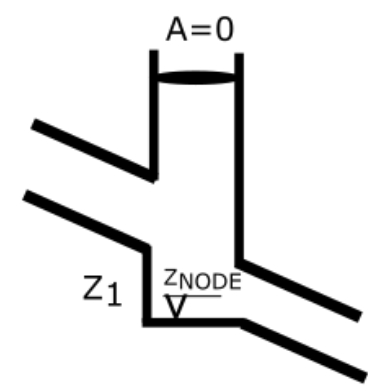

Manhole

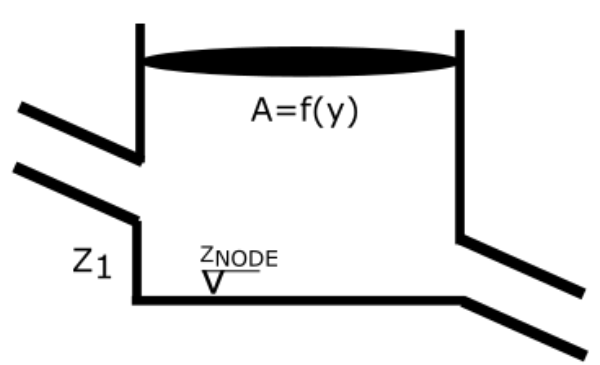

Storage Tank

Figure 1. Manhole and ST connection with pipes 


\subsection{Problem Formulation}

Networks rehabilitation aims to improve the networks and prepare them to the new challenges. In regard of the fact that extreme rainfalls can cause insufficiency to the network if no action is taken, it is important to properly select the rehabilitation strategy and the adequate optimization scenario to optimize the process. One hypothesis states that the process starts with the obtention of the calibrated model of the network. The numerical model of the network should replicate as accurately as possible the behavior of the network. Figure 2 represents the problem formulation of drainage network rehabilitation considering STs installation and pipes substitution.

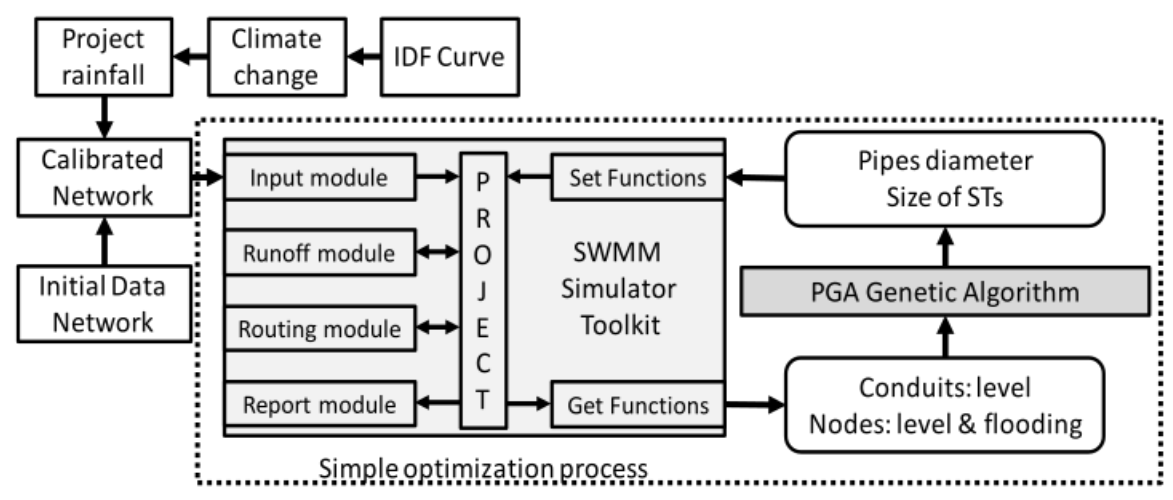

Figure 2. Flow chart of the optimization methodology based on the PGA algorithm and the toolkit of the SWMM model.

Once the calibration is complete, the network goes through a simple optimization process. SWMM is used to analyze the hydraulic behavior of the network for a set of DVs while the PGA uses data of pipe levels, node levels and the flooding in nodes to determine the optimal dimensions of the rehabilitated pipes and sizes of STs to install.

\subsubsection{Decision Variables}

The process of rehabilitation of a drainage network (Figure 2) involves modifying two types of DVs. In this case, pipe diameters and node storage capacity (The increase of nodes storage capacity is ensured by the installation of STs in the nodes).

Concerning variables related to pipe diameters, they seek to locate the best combination of sizes to obtain the minimum flooding. The optimization model analyzes the replacement of the pipes based on their transport capacity. The diameter may increase 
if the original pipe is insufficient to transport the flowing water or decrease if a hydraulic control device [53] should be installed to introduce the same head loss as the calculated pipe's diameter. Consequently, the DV is the size of the pipes, and can vary from 0 (not replace) to a maximum value set before beginning the optimization process. Obviously, if the result associated with a pipe is 0 , it is because it is not necessary to replace it for the correct operation of the network. The slopes and forms of pipes are maintained, since this thesis concerns rehabilitation. The Manning coefficient corresponds to the one of the new conduit to install. Then, for a better understanding of the optimization methodology, it is convenient to define some parameters related to the pipes. So, $N_{C}$ is the number of network conduits; $m$ is the number of feasible conduits selected to be replaced, varying between 1 and $N_{C}$; and $N D$ is the number of candidate diameters, between $N D_{0}$ and $N D_{\max }$.

Concerning variables related to node storage capacity, they seek the minimum volume of STs that reduce floods. The proposed methodology considers the possibility of installing an ST in each node of the network. This involves replacing an existing manhole with an underground ST. The land in which the rehabilitation of the drainage network is developed is mostly urban. Therefore, it is admitted that the depth of excavation is limited. Thus, the maximum depth of ST is what the manhole initially had, so the only parameter needed as DV is the ST cross section. Related to this, every node has a defined storage capacity related to its cross section and the model takes into account some nodes that could be modified into an ST. For this process, every node would have a DV representing the equivalent additional section corresponding to that of the STs in the case it would have been installed in the node location.

Again, the definition of some parameters related to the nodes is important for the understanding of the methodology. $N N$ is the number of network nodes and $n$ is the number of nodes selected to potentially install a ST, varying between 1 and $N N$. Each node in which an ST can be installed has the cross section $(S)$ as DV. Since a heuristic optimization model is used, it is necessary to perform a discretization of $S$. For this reason, a maximum value of the tank cross section $\left(S_{\max }=2000 \mathrm{~m}^{2}\right)$ is defined for each node. In this way, $N$ is the number of divisions in which $S_{\max }$ is divided. Therefore, $N$ determines the resolution of the section $\mathrm{S}$, varying between $N_{0}\left(N_{0}=10\right)$ and $N_{\max }$. $\left(N_{\max }=40\right)$. A simulation performed with the ST cross section divided into $N_{0}$ parts is faster than a simulation performed $N_{\max }$ divisions. So, to obtain better calculation times, the number of divisions of the ST cross section could be reduced.

The DV would vary between zero and a maximum value, predetermined before the optimization process and taking into account the restrictions of the urban geographical space of each node. If the nodes were not to be transformed into a ST, then the variable would have a value of 0 , meaning that, it is not adequate to install a ST on the specific node's location, maintaining thus the initial storage capacity of the node. In case the initial hydraulic model has any type of water deposit, the cross section of the deposit might be part of the optimization process.

For every node, whether it is regular or a storage node, its cross-section $\mathrm{S}$ would be expressed according to the following equation: 


$$
S=A_{S} \cdot Z^{B_{S}}+C_{S}
$$

In Equation (1), $A_{S}, B_{S}$ and $C_{S}$ are characteristic coefficients that adjust the tank's section to different expressions, and $z$ is the water level of the node. In the case of considering tanks of constant section, $A_{S}$ represents the cross section while the coefficients $B_{S}$ and $C_{S}$ are null. However, considering tanks with variable section does not imply a major difficulty in the problem implementation beyond choosing the right DVs.

As stated before, the size of the problem is a key aspect when trying to optimize real problems. In this thesis, the optimization algorithm takes into consideration both pipes and nodes. The maximum size of each rehabilitation scenario can be expressed by the following equation:

$$
P S_{\max }=N D_{\max }^{m} \cdot N_{\max }^{n}
$$

\subsubsection{Cost Functions}

As indicated in the hypotheses of the thesis, the objective function of the optimization problem is addressed in monetary units.

There are three cost functions used in this these:

- $\mathrm{C}_{1}$ : Pipes substitution cost function.

- $\mathrm{C}_{2}$ : STs installation cost function

- $\mathrm{C}_{3}$ : The flood damage cost function

The expressions of the cost functions are given by the following equations:

$$
\begin{gathered}
\mathrm{C}_{1}=\sum_{i=1}^{N_{C}} C_{C}\left(D_{i}\right) \cdot L_{i} \\
\mathrm{C}_{2}=\sum_{\mathrm{i}=1}^{N_{T}} C_{T}\left(V_{i}\right) \\
\mathrm{C}_{3}=\sum_{\mathrm{i}=1}^{N_{N}} C_{I}\left(y_{i}\right) \cdot A_{i}
\end{gathered}
$$


In Equation (3), $L_{i}$ represents the length of each conduit. While in Equation (5), $A_{i}$ represents the ponded area affected by flood for each flooding node.

These three cost functions are used to form the objective functions of the SO optimization and the MO optimization in this thesis. They convert hydraulic variable values into monetary units. Their description is presented in the following sections.

\subsubsection{Pipe substitution cost function}

During the rehabilitation process, some pipes are substituted by new ones because of structural defections, aging or insufficient transport capacity. This cost function represents their rehabilitation cost. It is derived from real data supplied by manufacturers. A mathematical formulation considering these data was carried out to express economically the cost of pipe substitution in euros per meter depending on the diameter of the pipe to be installed. This function was adjusted to Equation (6):

$$
\mathrm{C}_{C}\left(D_{i}\right)=A \cdot D_{i}+B \cdot D_{i}^{2}
$$

In Equation (6), $A$ and $B$ represent adjusts coefficients. Another possibility would be to use a table instead. This would suppose any difficulty to the methodology. However, the function has been chosen for simplicity without losing its precision.

\subsubsection{Storm tank installation cost function}

Depending on the calculated volume of a ST that can be installed on a node $\left(V_{i}\right)$, this cost function can be defined using real data supplied by manufacturers. Sizes of these tanks can be diverse. Their objective is to expand the storage capacity of the nodes or the STs originally installed in the network. The first term of the formulation represents the minimum costs relative to the construction $\left(C_{\min }\right)$ and the second term depends on the total volume through a coefficient $\left(C_{v a r}\right)$ and an exponent $(n)$. $C_{v a r}$ is obtained through the analysis of different tank's construction costs. The first term is fix while the second is variable:

$$
\mathrm{C}_{T}\left(V_{i}\right)=\mathrm{C}_{\text {min }}+\mathrm{C}_{v a r} \cdot V_{i}^{n}
$$

\subsubsection{Flood damage cost function}

In the literature, authors [35, 52 and 54] normally characterized floods as flooding volume and damage is not considered. According to Lee and Kim [55], flooding damage is different from flooding volume. They showed that some subareas can be immediately damaged by a certain amount of flooding while other subareas are not, 
confirming that flood damage depend on the land use. In the same way, $1 \mathrm{~m}^{3}$ of flooding will not affect equally $1 \mathrm{~m}^{2}$ and 1 ha. As flood damage costs represent the damages provoked by the flooding, Lee and Kim [55] represented flood damage costs in function of the depth reached by water. In this work, flood is considered as the highest depth reach by the water $(y)$ out of the network.

The ponded area $\left(A_{p}\right)$ related to each node is defined. Then, the highest depth reached by the water or the flood level can be obtained by dividing the flooding volume $\left(V_{f l}\right)$ by the ponded area $\left(A_{p}\right)$. In Equation (8), T represents the flooding duration and $\mathrm{t}$ represents any instant in the flooding duration.

$$
\begin{gathered}
V_{f l}=\sum_{t=0}^{T} Q_{o v} \cdot \Delta t \\
y=\frac{V_{f l}}{A_{P}}
\end{gathered}
$$

Once the flood level is defined, it can be used to determine the flood damage cost. It is also necessary to define $\mathrm{C}_{\max }$ that represents the maximum cost per square meter that a flooding might provoked. A generic form to obtain the flooding cost values depending on different land use is presented on Figure 3.

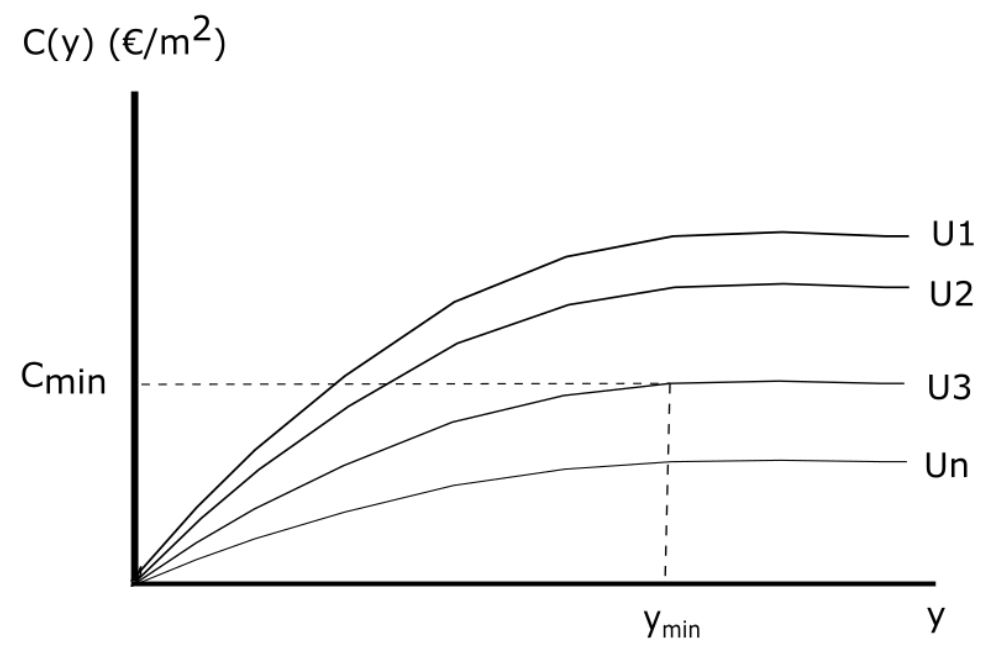

Figure 3. Flooding cost for different land uses

$U_{1}, \ldots, U_{n}$ represent the different land uses. $Y$ is the depth reached by water. In this thesis, the flooding cost has been studied in detail according to Colombian values 
and land uses [56]. These values are linked with the repair budget that the insurance companies or consortiums faced.

Based on all those data, a flood damage cost has been defined and proposed in this work. Its expression is given by Equation (10):

$$
\mathrm{C}_{I}\left(y_{i}\right)=\mathrm{C}_{\max } \cdot\left(1-e^{-k \cdot \frac{y_{i}}{y_{\max }}}\right)^{2}
$$

In Equation (10), for a certain depth $\left(y_{\max }\right)$, the damage is considered as irreparable and therefore, the function stops growing, and the cost will reach this maximum value. Coefficient $k$ is based on studies of damages caused by flooding processed for Columbia [56].

\subsection{Single-objective optimization}

The optimization process in the drainage network formulation problem consists of the minimization of a defined objective function describing the problem to solve. As cost functions are addressed in monetary units, they can be summed. These cost functions convert hydraulic variable values into monetary units. They represent:

- The investment cost related to the substitution of the pipes of the network.

- The investment cost linked to required volumes of STs to be installed in the nodes.

- The flood damage cost caused by the flooding level in various nodes of the network.

In order to give different weights, Lagrange multiplier $\lambda_{1}, \lambda_{2}$ and $\lambda_{3}$ might be used. The objective function for single-objective optimization is given by the following mathematical expression:

$$
F=\lambda_{1} C_{1}+\lambda_{2} C_{2}+\lambda_{3} C_{3}
$$

In Equation (11), the first term represents the rehabilitation or substitution cost of the $N_{C}$ considered pipes in the network. The second term represents the construction or expansion cost of volume $V_{i}$ of the $N_{T}$ STs installed in the drainage network. This cost concerns the existing STs which volume will be expanded, and the network nodes where new STs will be installed. The third term represents the total flood damage costs caused by the $N_{N}$ nodes in which a certain flooding volume $\left(V_{f l}\right)$ appears and water reach a highest depth $y_{i}$.

This optimization problem was solved using PGA [13] that has been previously used for other problems [57]. PGA needs the DV to be defined. As explained above, $m$ is the number of pipes whose diameters can change and $n$ are the possible locations of STs. The range of variations of these DVs must also be defined. The number of candidate diameters $N D$ varies between $N D_{0}$ and $N D_{\max }$. The resolution $N$ of the section $\mathrm{S}$ varies 
between $N_{0}$ and $N_{\max }$. The SO optimization algorithm can be schematically represented as in Figure 4.

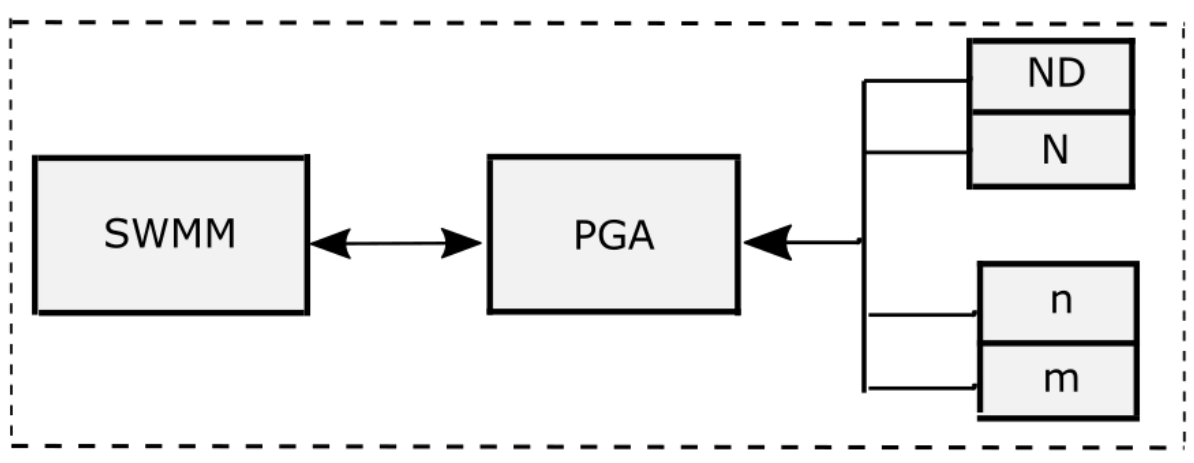

Optimization SWMM+PGA

Figure 4. Basic parameters of a single-objective optimization process considering PGA.

Figure 4 represents the optimization process using SWMM and PGA. This process is included in Figure 2. The basic parameters $N, N D, n$ and $m$ presented on Figure 4 can be modified. The algorithm will be used several times in this thesis.

Besides, PGA needs the genetic operators to be defined. These operators use the following parameters:

- Population size: $N_{\text {pop }}$

- Reproduction probability

- Mutation probability.

- Termination criterion: $N_{\text {gen }}$

For the SO optimization presented in this thesis, the following values of genetic operators were used: $N_{\text {pop }}=100$ and $N_{\text {gen }}=100$.

\subsection{Multi-objective rehabilitation}

For the SO optimization, three cost functions were summed to form an objective function. It is observed that cost functions have two types. Investment costs that can be obtained from manufacturers data and size of pipes and STs to install. And flood damage costs that depend on the rainfall event probability of occurrence. The difficulty to sum the two types of costs lies in the fact that the probability of occurrence of the rainfall event cannot be known in advance. Therefore, it is necessary to propose a MO optimization to solve this issue. 


\subsubsection{Objective functions}

The optimization process is based on the minimization of an objective function. In this case, two objectives are conflicting in the objective function proposed. On one hand, the investment costs; and, on the other hand, the flood damage costs. There is a hydraulic connection between the two types of costs. Investments imply increasing transport capacity of the network and, consequently, reducing floods. More investments reduce flood damage costs and vice versa.

The investment costs function $\left(F_{1}\right)$ and flood damage function $\left(F_{2}\right)$ corresponding to the $\mathrm{MO}$ optimization objective functions are represented by Equations (12) and (13).

$$
\begin{gathered}
F_{1}=\lambda_{1} C_{1}+\lambda_{2} C_{2} \\
F_{2}=\lambda_{3} C_{3}
\end{gathered}
$$

\subsubsection{Proposed methodology}

To relate both concepts, a mathematical model of the drainage network has been combined with a MO optimization algorithm. Let a solution be a set of corrective actions adopted for the network. For every proposed solution, the hydraulic solver calculates the behaviour of the network focusing in the presence of flood. Then, the fitness is calculated with both installation costs and flood damage costs. Finally, the optimization algorithm ranks every feasible solution to produce the next generation of solutions until the termination criterion is reached. The coupling between the optimization algorithm and the hydraulic model was made using a connection library as described in [12]. An outline of the process is shown on Figure 5. 


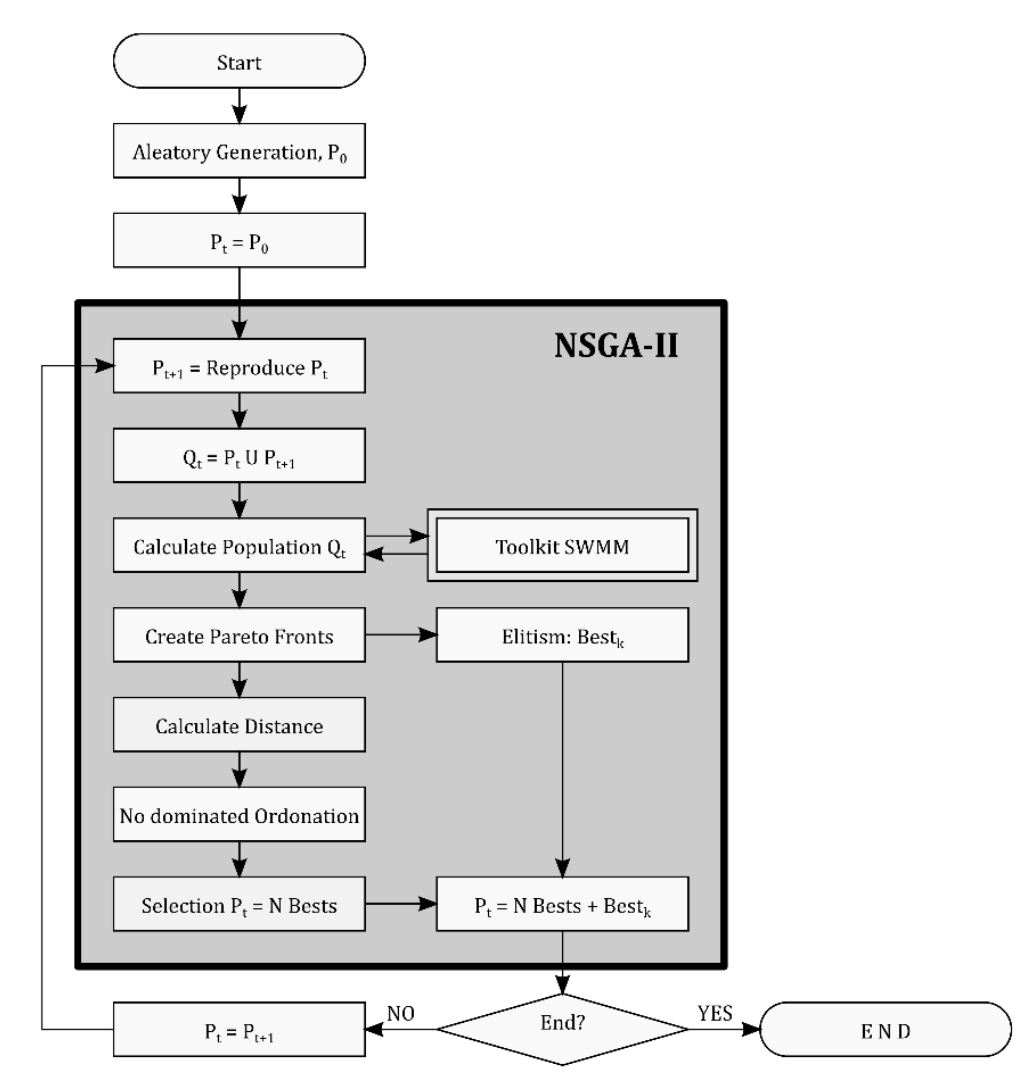

Figure 5. Flow chart of NSGA II performed in this thesis.

\subsubsection{Optimization algorithm}

In the problem presented above, two objective functions are conflicting. That is, the improvement of one may worsen the other. A solution is dominated if there is another solution that improves all its objective functions. A solution is non-dominated if there is no other solution that dominates it. The set of all non-dominated solutions is called a Pareto front. The Pareto front might be formed by a high number of non-dominated solutions. In this case, the NSGA-II algorithm will be used. NSGA-II was first introduced by Deb et al. [14]. This method adopts a fast non-dominated sorting approach to rank solutions through an implicit elitist selection method based on the concepts of Pareto dominance and crowding distance. In Pareto front, a set of optimal solutions is presented. The crowding distance of a solution for an objective is the average distance of its two neighbouring solutions. As an example, a two-objectives optimization problem 
will be used. After selecting the non-dominated solutions, the Pareto front can be represented as on Figure 6. The crowding distance for objective F1 and F2 can be calculated according to the following Equations (14) and (15) respectively.

$$
\begin{aligned}
& d_{1}(i)=F_{1}(i+1)-F_{1}(i-1) \\
& d_{2}(i)=F_{2}(i+1)-F_{2}(i-1)
\end{aligned}
$$

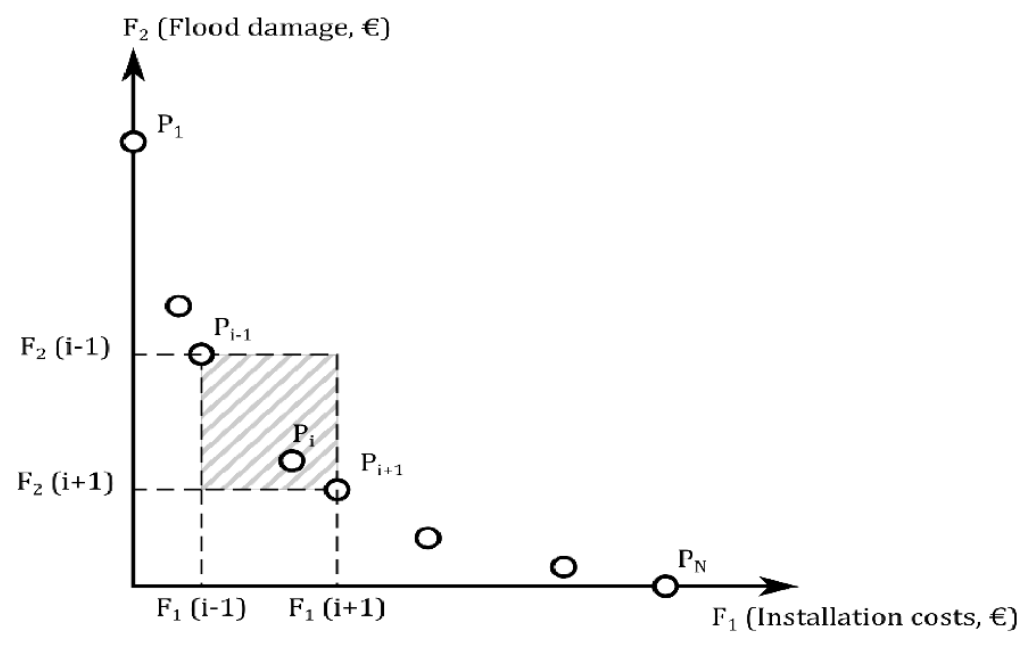

Figure 6. Main features of a Pareto front.

The crowding distance of the solution $i$ is calculated from the crowding distance of every objective, using different approaches:

Orthogonal distance:

$$
d(i)=\left|d_{1}(i)\right|+\left|d_{2}(i)\right|
$$

Euclidian distance:

$$
d(i)=\sqrt{d_{1}^{2}(i)+d_{2}^{2}(i)}
$$

Hyper-volume:

$$
d(i)=\left|d_{1}(i)-d_{2}(i)\right|
$$

In this thesis, the orthogonal distance was chosen. In a general form, for No objectives, it can be expressed as: 


$$
d(i)=\sum_{j=1}^{N O} d_{j}(i)
$$

Each objective function is used to calculate the crowding distance of a solution. They allow to calculate the distance on an axis between two boundary solutions with the lowest and the highest objective function value [58]. For the extreme values without neighbours on the two sides, maximal value of crowding distance will be used:

$$
d_{1}(1)=d_{1}(N)=F_{1}(N)-F_{1}(1)
$$

The crowding distance of a solution is an estimation of the density of solutions surrounding that solution.

Besides, an additional elitism aspect was added for this work. For every generation, the best individual in every objective was selected for the next generation. That is, according to Figure 6 , individuals $P_{1}$ and $P_{N}$ were selected for the next generation. Usually, the stopping criterion for $\mathrm{MO}$ algorithms is the number of simulations or generations. In this case, the evolution of the best values for every objective was also used as stopping criterion. If after a certain number of generations none of the values of the objectives $\left(\mathrm{F}_{2}\left(\mathrm{P}_{1}\right)\right.$ and $\left.\mathrm{F}_{1}\left(\mathrm{P}_{\mathrm{N}}\right)\right)$ were improved, the algorithm can stop. The two precedent stop criteria are used and should be fulfilled. Another measure for assessing the algorithm was the evolution of the crowding distance. It is desirable that solutions in a Pareto front were equally distributed. In this sense, the standard deviation of the crowding distance in the first Pareto front was also taken as a measure of the quality of the front. The smaller the standard deviation, the better the solution. On Figure 6, $\mathrm{P}_{\mathrm{i}}$ represents the non-dominated solution whose crowding distance is calculated. $\mathrm{P}_{\mathrm{i}+1}$ is its boundary solution with highest objective function value, while $\mathrm{P}_{\mathrm{i}-1}$ is its boundary solution with lowest objective function value.

\subsection{Search space reduction methodology}

For the three scenarios defined in the Chapter Introduction of this thesis, simulations were run for SO and MO. The following observations have been made: Due to the number of DV s considered, the SS was so large. The optimization algorithms PGA for SO and NSGA-II for MO had difficulties to entirely explore the search space (SS). Solutions obtained when these simulations were performed were caught up in local minima. In fact, there were various local minima that hinder the optimization algorithms to find good solutions. This supposed a problem to achieve optimal rehabilitation of drainage networks. However, there are some studies in the literature [51, 52] that proposed the SSR to reduce the problem size and achieve better results in water resources management. 
As a previous step, some algorithm tests were performed considering the full SS, i.e, all the nodes and lines of the network. According to protocol, several tests were carried out, in which it was appreciated that the SS is so large that the algorithm barely finds good solutions. The enormous number of local minima causes damages to the algorithm. A smaller SS allows the optimization algorithm to easily find minimum values.

A methodology was initially proposed for SO. This SSR is based on the run of various simulations of SO with a reduced SS. Additionally, this SSR will improve the solutions found by the PGA when the entire SS was used. According to Equation (2), the size of the problem might be reduced using two mechanisms:

a) Reduce the number of DVs:

- $\quad$ Reduce $n$

- $\quad$ Reduce $m$

b) Reduce the variation range of each DV:

- $\quad$ Reduce the discretization $N$.

- Reduce the number of candidate diameters $N D$.

These DVs and their variation range was early presented in Figure 4.

The two mechanisms to reduce the SS have been organized for SO optimization to propose an SSR methodology in two steps: Pre-locating STs and preselecting conduits. Figure 7 presents the Block diagram of the SSR methodology proposed in this thesis. 


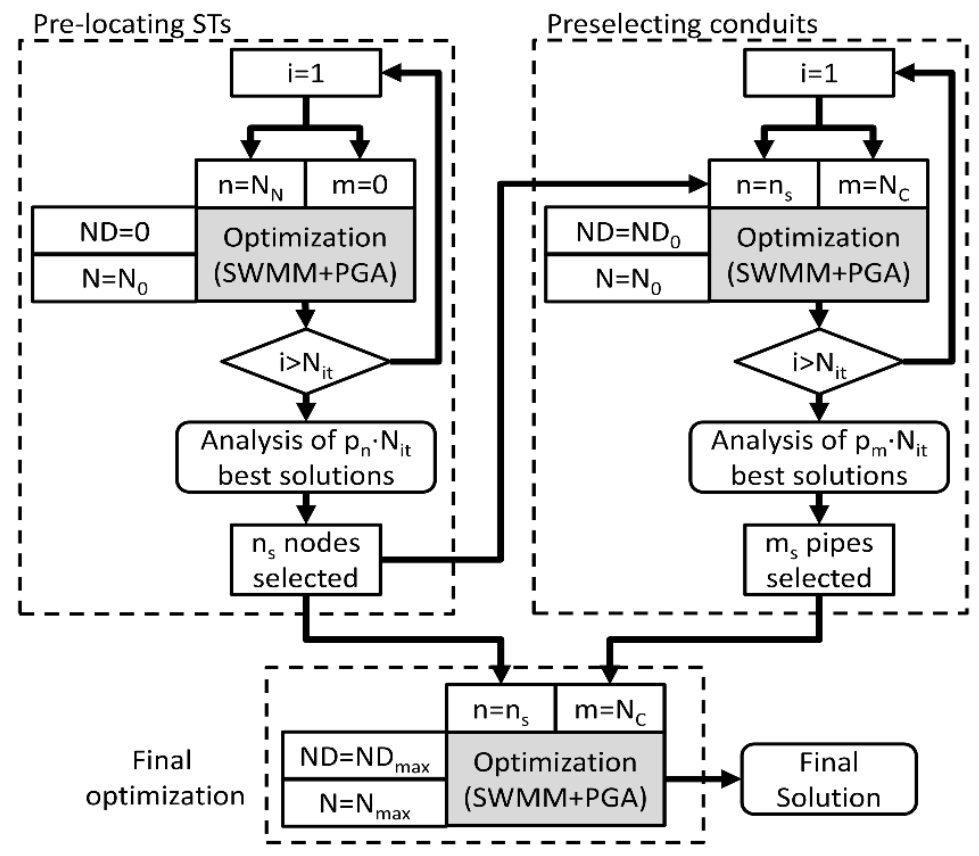

Figure 7. Block diagram of the SSR methodology.

\subsubsection{Pre-locating Storm Tanks}

There are some previous studies oriented to the pre-locating of STs [34]. In the study carried by Cunha et al. [34], tanks are tested only a priori, but it is not in itself a method of pre-location. The pre-location of Cunha et al. did not consider hydraulic analysis criteria. It only considered the preliminary study of the region. However, in this case the methodology described on Figure 7 is used as a basic tool to determine the possible locations of the STs. The first step of the methodology (pre-location of STs) is summarized on the left-hand side of Figure 7. Some runs $\left(N_{i t}\right)$ are performed with all the nodes of the network $\left(n=N_{N}\right)$, but without including the pipes in the optimization process $(m=0)$. Thus, $N_{i t}$ optimizations are made, considering only the cross section $(S)$ of the tanks as DVs and without modifying the diameters of the network. Since the objective is the reduction of the SS, the discretization of the cross sections of the tanks $(S)$ is carried out with a small number of divisions $\left(N=N_{0}\right)$. This coarse discretization of each section is carried out since the objective is not to calculate its exact value, but to determine in which nodes the installation of an ST is adequate. That is, the objective of this step is to select the nodes where STs could be installed in the rehabilitation of the network. 
In this step, the obtained solutions of initial trial runs are ranked according the value of the objective function. Each of these solutions contains a distribution of STs in the network and a dimensioning, even being approximate, of the ST size required in each node. However, the analysis is not focused on the size of the STs but on their location. Therefore, a percentage $p_{n}$ of the best simulations is selected. The analysis of these simulations allows identifying the nodes where an ST could be installed, and a list of $n_{s}$ possible locations is created. These nodes are selected because they are repeated as the location of an ST in all the $p_{n}$ selected solutions.

\subsubsection{Pre-selecting conduits of possible pipes substitution}

The objective of this second step is to reduce the number of pipes whose diameters can be modified. For that purpose, the $n_{s}$ selected nodes are combined with all the conduits of the network $\left(m=N_{C}\right)$ to perform new trial runs $\left(N_{i t}\right)$. STs are again discretized in $N=N_{O}$ divisions (its minimum value) and the number of candidate pipes diameters is a reduced range $\left(N D=N D_{0}\right)$. In this step, the aim is to find a pre-location of pipes to be substituted.

In a similar way to the previous step, the obtained solutions of trial runs are ranked from the best to the worst value of the objective function; and a percentage $p_{m}$ of the best solutions are selected. Analyzing these solutions, the list of $m_{s}$ pipes whose replacement is repeated in the $p_{m}$ best solutions is selected.

\subsubsection{Location and optimization of STs and pipes diameters}

The presented SSR methodology has been applied to SO for validation. So, a last step considering the results of the two previous steps was performed: the pre-location of the STs and the location of the pipes that could potentially be rehabilitated is added. A simulation is defined with the $n_{s}$ selected nodes and the $m_{s}$ selected lines. Although the number of DVs is smaller, the exploration of each of these variables must now be greater. Therefore, the STs are discretized to the maximum $\left(N=N_{\max }\right)$ and the list of candidate diameters for the conduits is also the largest $\left(N D=N D_{\max }\right)$. This final optimization determines the location and size of the STs to be installed and the diameters of the pipes to be rehabilitated.

In short, the SSR in a problem with continuous and discrete variables has been based on two aspects: the reduction of the number of DVs and the level of detail of each of the variables. During the first two stages the number of DVs is reduced by two analyzes with a lower level of exploration of each variable. In the final simulation, a smaller number of variables is used, but with a higher level of exploration. This combined use of the initial optimization algorithm allows obtaining better solutions to problems with many solutions and local minima. 


\subsection{Methodology proposition for multi-objective optimization}

Based on results obtained for the SSR methodology for SO optimization, a MO optimization methodology considering SSR has been proposed for urban drainage networks rehabilitation. The SSR methodology proposed for SO optimization could not be applied to MO optimization in the same way, due to the elevated calculation time. So, a new methodology has been proposed and the flow chart is presented on Figure 8.

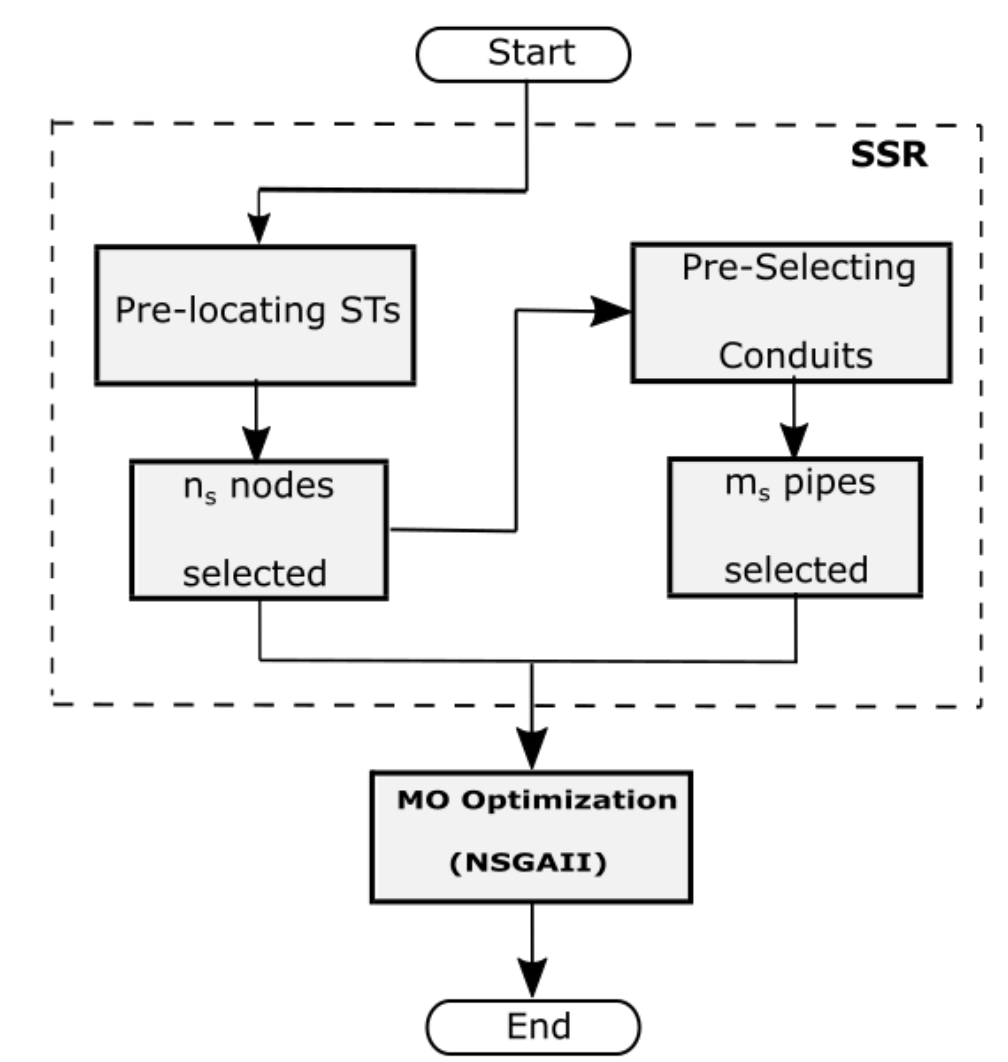

Figure 8. Flow Chart of MO optimization methodology considering SSR technique.

The proposed methodology is composed of two complementary parts that together form a complete drainage network optimal rehabilitation methodology. The first part is called SSR and the second part is the application of a multi-objective evolutionary algorithm that can be applied to any drainage network. 
In the first part of the methodology an SSR technique is applied to reduce the problem size. $N_{i t}$ simulations are run for a SO optimization of the network with the following configuration: $n=N_{N}, N=N_{0}, m=0$ and $N D=0$. As explained in the previous section.

The solutions of the $N_{i t}$ simulations are ranked in term of objective function values from the best to the worst value. Based on a probability $p_{n}$, the $n_{s}$ best solutions are selected. They correspond to the list of nodes where STs could be installed. This process is the pre-location of STs and is presented on the left-hand top of the Figure 8.

$N_{i t}$ simulations are also run for a SO optimization of the network with the following configuration: $n=n_{s}, N=N_{0}, m=N_{C}$ and $N D=N D_{0}$.

The solutions of the $N_{i t}$ simulations are ranked in term of objective function values from the best to the worst value. Based on a probability $p_{m}$, the $m_{s}$ best solutions are selected. They correspond to the list of lines where pipes could be substituted. This is the pre-selection of lines of possible pipes substitution and is presented on the righthand top of the Figure 8.

Once the list of $n_{s}$ nodes and $m_{s}$ is obtained, they form the new DVs of the MO optimization. The NSGA-II adopted in this part of the methodology include an additional elitism: the best individual in every objective is maintained in the population and is used in the next generation.

Two sopping criteria are adopted and should be satisfied: the number of generations and the improvement of the objective function after a certain number of generations. Solution are presented in form of Pareto fronts for investment costs against flood damage costs. 


\section{Chapter 5}

\section{Case studies and results}

\subsection{Introduction}

During the development of this thesis, each of the techniques presented in the chapter methodology was applied to different drainage networks to validate its functioning, effectiveness and robustness. Thus, three drainage networks were selected based on their characteristics.

The first network is a simple academic network presented by Mora-Meliá et al. [59]. This network here by named SN-network allowed to apply the SO optimization methodology based on Toolkit of SWMM model and PGA algorithm described on Figure 2 of the previous chapter. This network is simple but allows to validate the functioning of models and understand methodologically the functioning of each step of the model. This network was used as a test network for all the algorithms developed in this thesis. Data of the network (rainfall curves, cost functions, nodes, pipes diameters) can be found in the supplementary material of Appendix III.

The second network is a medium size network called E-chicó. It was used to apply the SO optimization, the MO optimization and the SSR methodology. E-chicó is a part of the drainage network of Bogotá city (Colombia). Data of characteristics of EChicó drainage network such as nodes, conduit diameters and sub-catchments are supplied in Appendices III and IV. 
Finally, the drainage network called Ayurá was used due to its large size and the fact it is a mesh network to apply the MO optimization considering SSR technique proposed in this thesis. Ayurá is a sub-catchment of the drainage network of Medellin city (Colombia). Data of the network (rainfall curves, cost functions, nodes, pipes diameters) can be found in the supplementary material of Appendix III.

In the papers published there are more results. However, here only one example will be presented for each step of the thesis because, this part is the memory of the thesis.

Five rehabilitation scenarios will be defined for the case studies presented in this thesis. The lasts two scenarios will be applied only on steps where SSR is considered. The five scenarios are:

- Scenario 1: Rehabilitation of the network considering all the conduits.

- Scenario 2: Rehabilitation of the network considering all the nodes as possible locations for STs.

- Scenario 3: Rehabilitation of the network considering all the conduits and all the nodes as possible locations for STs.

- Scenario 4: Rehabilitation of the network combining the possible installation of STs on the $n_{s}$ selected nodes and the $m_{s}$ conduits that can be substituted. for $p_{n}=10 \%$ and $p_{m}=10 \%$.

- Scenario 5: Rehabilitation of the network combining the possible installation of STs on the $n_{s}$ selected nodes and the $m_{s}$ conduits that can be substituted. for $p_{n}=10 \%$ and $p_{m}=5 \%$.

For all the cases, the same cost functions were used. The constant values needed to optimize the objective functions of Equations (11), (12) and (13) are presented in the following tables:

Table 1. Coefficients of pipes and storm tanks cost curves.

\begin{tabular}{ccccc}
\hline A & B & Cmin & Cvar & $\mathrm{n}$ \\
40.69 & 208.06 & 16923 & 318.4 & 0.65 \\
\hline
\end{tabular}

Table 1 presents the adjusting coefficients of pipe substitution cost function and STs installation cost function.

The full range of commercial diameter and corresponding substitution cost used in this thesis is presented on Table 2.

Table 2. Full range of commercial diameter used in the thesis $N D=N D_{\max }=25$.

\begin{tabular}{lcccccccc}
\hline $\mathrm{D}(\mathrm{mm})$ & 300 & 350 & 400 & 450 & 500 & 600 & 700 & 800 \\
$\mathrm{C}(€ / \mathrm{m})$ & 30.93 & 39.73 & 49.56 & 60.44 & 72.36 & 99.31 & 130.43 & 165.71 \\
\hline $\mathrm{D}(\mathrm{mm})$ & 900 & 1000 & 1100 & 1200 & 1300 & 1400 & 1500 & 1600 \\
$\mathrm{C}(€ / \mathrm{m})$ & 205.15 & 248.75 & 296.51 & 348.43 & 404.51 & 464.76 & 529.16 & 597.73 \\
\hline $\mathrm{D}(\mathrm{mm})$ & 1800 & 1900 & 2000 & 2200 & 2400 & 2600 & 2800 & 3000 \\
$\mathrm{C}(€ / \mathrm{m})$ & 747.35 & 828.4 & 913.61 & 1096.52 & 1296.07 & 1512.27 & 1745.11 & 1994.6 \\
\hline
\end{tabular}


The reduced range of commercial diameter and their corresponding substitution costs are presented in Table 3.

Table 3. Reduced diameter range $\left(N D=N D_{0}=10\right)$.

\begin{tabular}{rrrrrrrrrr}
\hline $\mathrm{D}(\mathrm{mm})$ & 300 & 400 & 600 & 800 & 1000 & 1200 & 1500 & 1800 & 2000 \\
$\mathrm{C}(€ / \mathrm{m})$ & 30.93 & 49.56 & 99.31 & 165.7 & 248.74 & 348.43 & 529.16 & 747.35 & 913.61 \\
\hline
\end{tabular}

It can be observed in tables 2 and 3 that there are only 24 values and 9 values respectively. The no action state is considered but not mentioned in the tables. So, there is a case when the diameter is not to be changed, the value associated is 0 . This was explained in the section 4.2.1.

A curve representing the flood cost by $\mathrm{m}^{2}$ of area in function of the flood level was obtained for 6 different social stratums, a commercial area and an industrial area. The curve is presented on Figure 9.

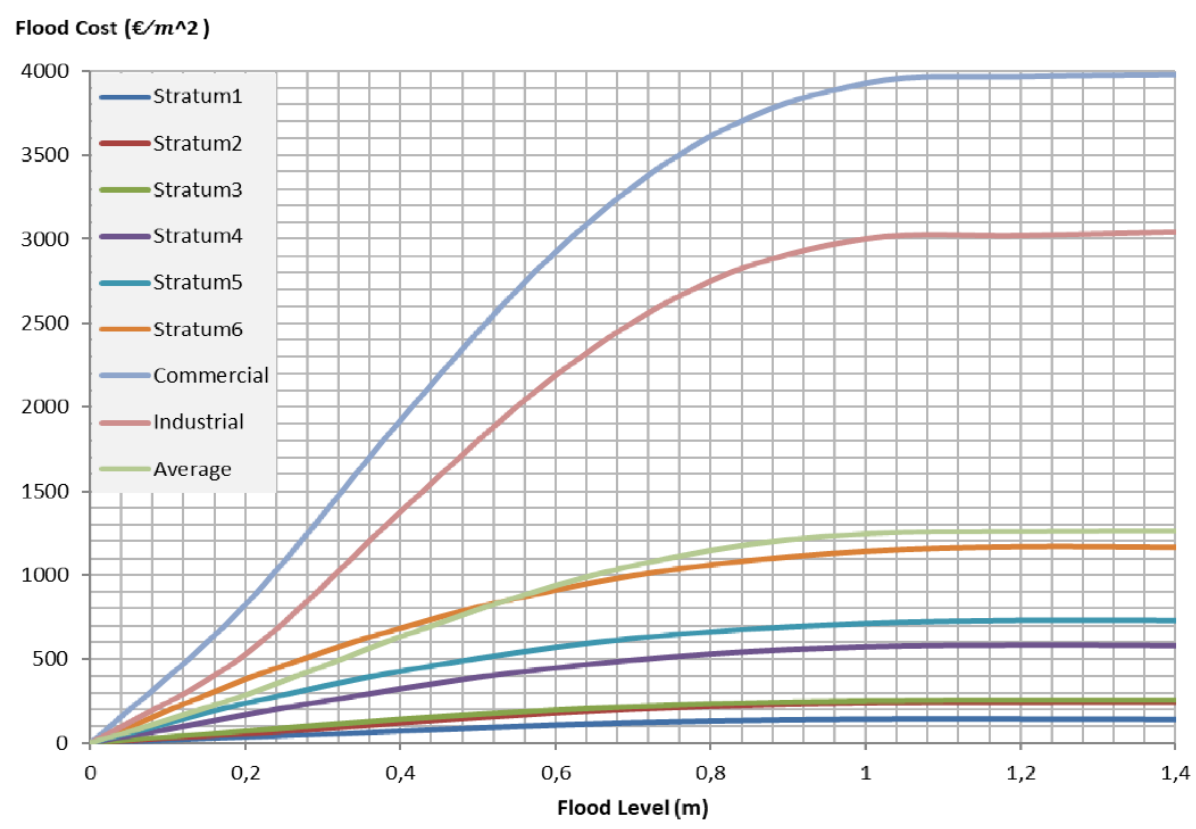

Figure 9. Flooding costs for different social Stratum linked to land uses.

Flood damage cost depends on land use. So, the values of $C_{\max }$ for different social stratum are presented in Table 4. 
Table 4. $C_{\text {max }}$ values for different social Stratum (Str) linked to land uses.

\begin{tabular}{cccccccccc}
\hline Land Use & Str. 1 & Str. 2 & Str. 3 & Str. 4 & Str. 5 & Str. 6 & Commercial & Industrial & Average \\
$C_{\max }\left(€ / \mathrm{m}^{2}\right)$ & 142 & 245 & 257 & 584 & 732 & 1168 & 3975 & 3041 & 1267 \\
\hline
\end{tabular}

A weighted average was performed and the following results were obtained: $C_{\max }=1268 € / \mathrm{m}^{2}, k=4.89$ and $y_{\max }=1.4 \mathrm{~m}$.

For PGA and NSGA-II, the cross-over probability is fixed at $80 \%$ and the mutation probability is equal to the inverse of DVs number as suggested by [58].

\subsection{Application of SO optimization to SN-Network}

The SN-network (Figure 10) is divided in 6 hydrological sub-catchments expanded over 18.24 ha. The network is composed of 6 circular conduits connecting 6 nodes. The total length of the network is $2400 \mathrm{~m}$. The network layout allows it to function by gravity and transport rainwater. The unevenness between the highest point and the lowest of the network is $4 \mathrm{~m}$.

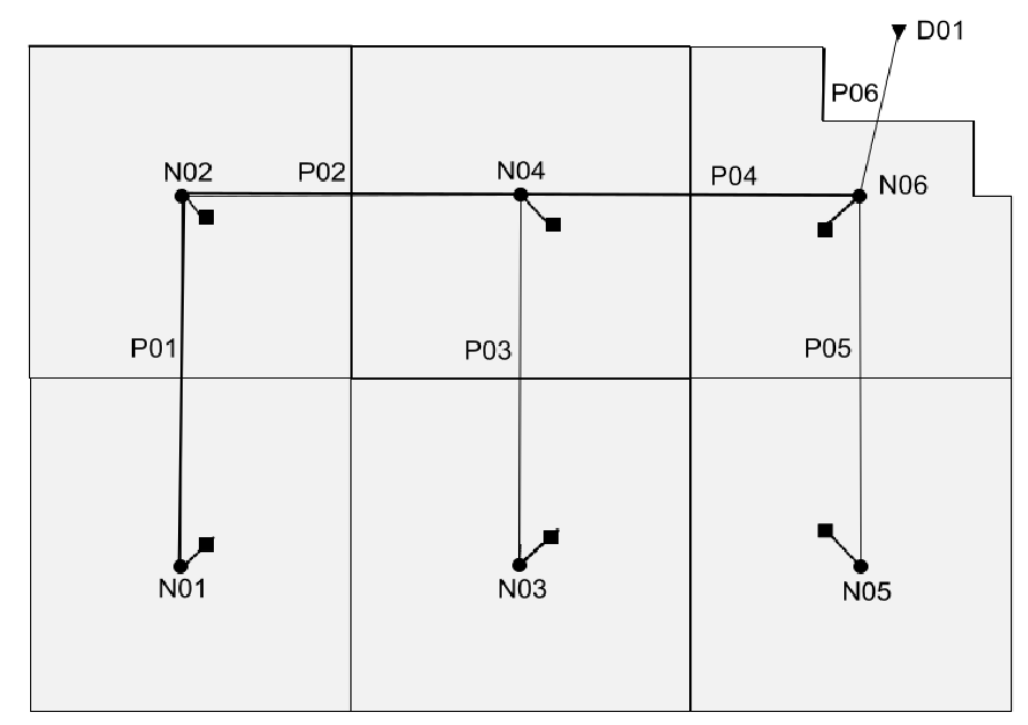

Figure 10. SN-network representation.

The diagnosis of the network and the evaluation of the possible solutions have been carried out using a project rain obtained by means of the alternating blocks method and the IDF curve. Figure 11 presents the project rain with a time interval of 10 minutes. 


\section{I $[\mathrm{mm} / \mathrm{h}]$}

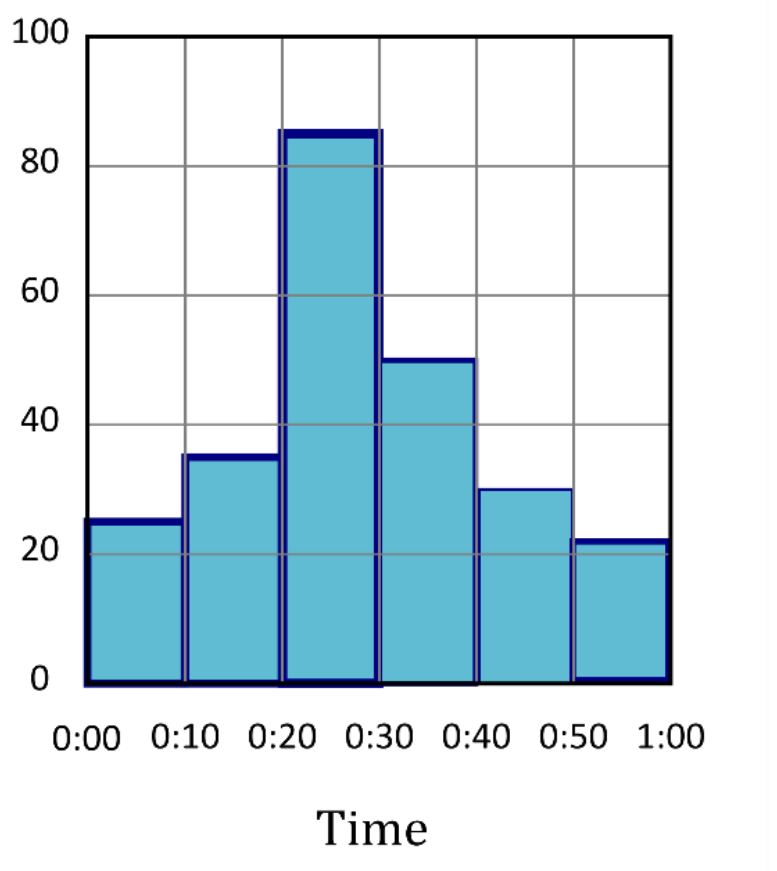

Figure 11. Project rainfall used in the case study.

A first simulation without any taken action showed the behavior of the network. In this preliminary analysis, the network presented a flooding total volume of $5765 \mathrm{~m}^{3}$, which represents $99.29 \%$ of the generated runoff $\left(5806 \mathrm{~m}^{3}\right)$. All the nodes of the network are flooding and 5 of the 6 pipes reached their maximal transportation capacity. In short, the preliminary analysis of the network shows that it is unable to drain the selected project rain. Therefore, the simple drainage network was considered adequate to apply the simple optimization process presented on Figure 1.

To improve the network, three different rehabilitation scenarios were performed depending on the selection of the DVs:

- Scenario 1: 6 conduits.

- Scenario 2: 6 STs.

- Scenario 3:6 STs and 6 conduits.

The results obtained after the application of the SO methodology to the SNnetwork are presented on Table 5. 
Table 5: Results summary of the simple network optimization process

\begin{tabular}{cccccccccc}
\hline \multirow{2}{*}{ Scenario } & \multicolumn{2}{c}{ No. DVs } & $\begin{array}{c}\text { Objective } \\
\text { Function }\end{array}$ & Costs of the objective function & $\begin{array}{c}\text { No. elements in } \\
\text { the solution }\end{array}$ & $\begin{array}{c}\text { Problem } \\
\text { size }\end{array}$ \\
& Nodes & Lines & Costs & Floods & STs & Pipes & STs & Pipes & \\
\hline 1 & 0 & 6 & 446,854 & 15,982 & 0 & $\begin{array}{c}430,87 \\
2\end{array}$ & 0 & 6 & $1 \cdot 10^{18}$ \\
2 & 6 & 0 & 263,601 & 3,719 & 259,881 & 0 & 6 & 0 & $2.4 \cdot 10^{8}$ \\
3 & 6 & 6 & 247,239 & 6,484 & 184,651 & 56,104 & 4 & 2 & $4 \cdot 10^{9}$ \\
\hline
\end{tabular}

The results of the optimization process allow to compare the effects of the different rehabilitation scenarios on the network. The results show that the combination of diameters changes and STs installation gives better results than the optimization of any of them separately in terms of the objective function values.

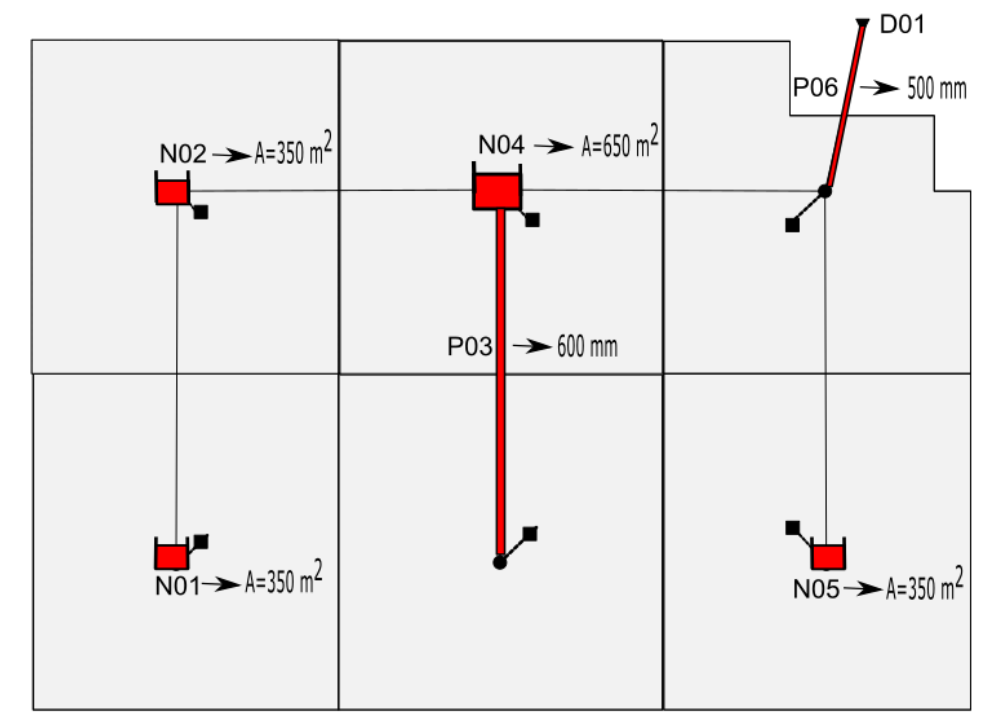

Figure 12. Representation of STs installed and pipes to replace according to scenario 3 results.

Figure 12 presents the location of the STs obtained in scenario 3, as well as their sizes. Additionally, the figure presents the lines that have been substituted and the size of the new conduits. It can be observed that P03 new diameter is $600 \mathrm{~mm}$ and P06 new diameter is $500 \mathrm{~mm}$. This can be explained by the fact that in the node N03 a ST is not installed to store the arriving runoff and therefore a bigger diameter is needed to transport 
the runoff. A ST is installed in node N04 and increases the concentration time downstream. Additionally, the slope of conduit P06 is favourable to the transport of runoff. This justify why diameter of P03 is bigger than diameter of P06.

\subsection{Application of SO optimization and SSR to E-Chicó.}

In the study of E-Chicó, a complete SO optimization is performed. Due to network SS size, the risk to be caught up in local minimal and not reach good solutions is elevated. So, the SSR is then analysed.

The part of the drainage network studied is generically known as E-Chicó district. E-Chicó (Figure 13) is divided into 35 hydrological sub-catchments expanded over a surface of 51 ha. The network is composed of 35 circulars conduits with diameters varying from 300 to $1400 \mathrm{~mm}$, and 35 connecting nodes. The total length of the network is around $5000 \mathrm{~m}$. The network works completely by gravity since the terrain profile is favourable to the drainage of rainwater. The level difference between the highest point and the lowest is $39.28 \mathrm{~m}$. Figure 13 shows E-Chicó drainage network. Data of characteristics of E-Chicó drainage network such as nodes, conduits and sub-catchment are supplied in Appendices III and IV.

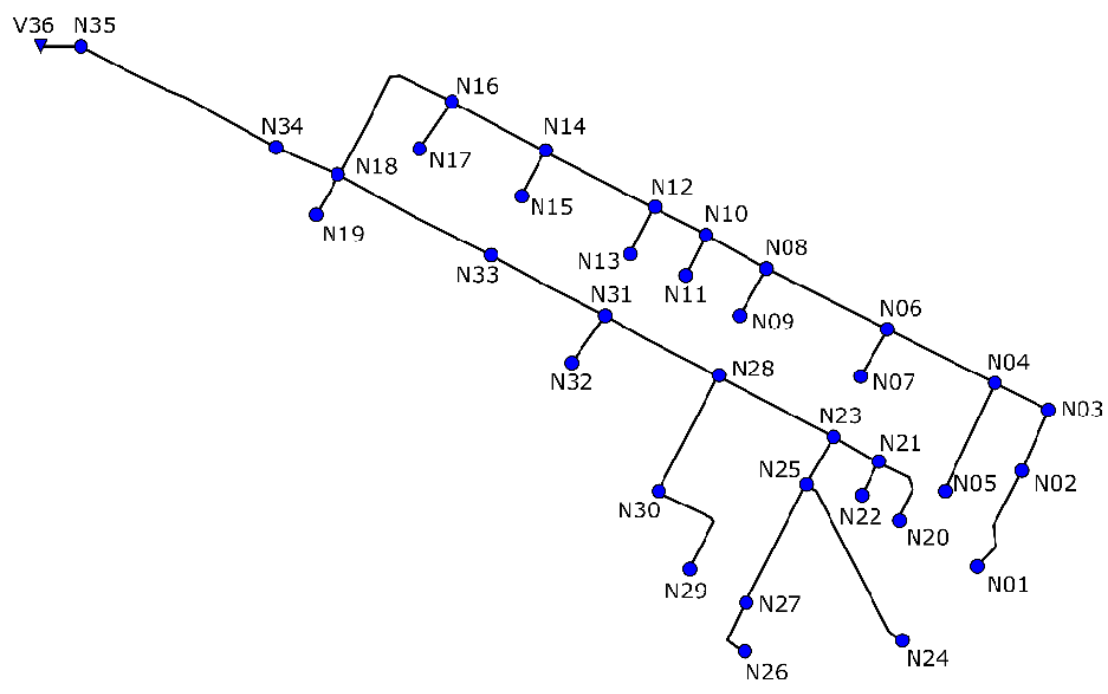

Figure 13. Representation of E-Chicó drainage network. 
For the analysis of the network, a design storm was used based on the IDF curve for a return period of ten years. Then, a design storm was calculated using the alternating block method with a time interval of 5 minutes and a minimum duration of 10 minutes. The design storm is presented in Figure 14.

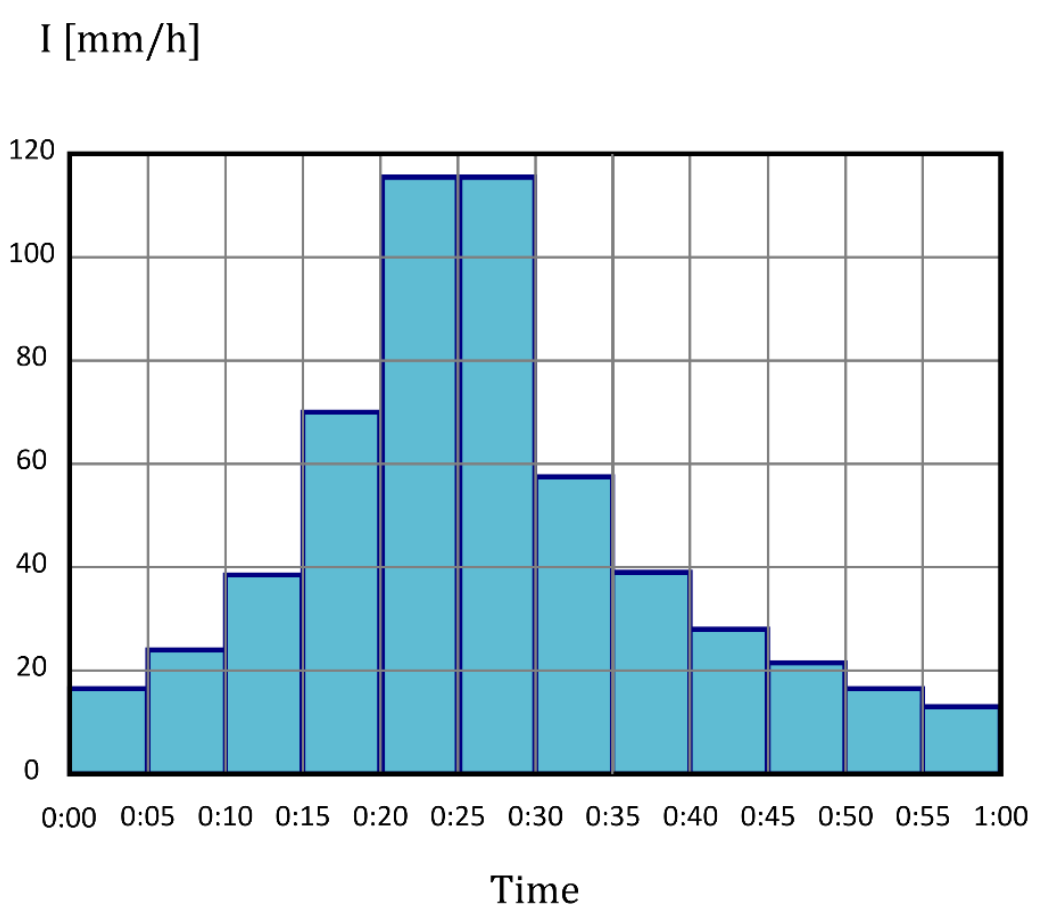

Figure 14. Project rainfall used in the application.

Five different rehabilitation scenarios were performed depending on the selection of DVs. Scenarios 4 and 5 were obtained after application of SSR to the complete network.

- Scenario 1: 35 conduits.

- Scenario 2: 35 STs.

- Scenario 3: 35 STs and 35 conduits

- Scenario 4: 15 STs and 15 conduits

- Scenario 5: 15 STs and 8 conduits

The results obtained from the optimization of the five scenarios considered are shown in Table 6. 
Table 6. Results summary of E-Chicó Optimization Process.

\begin{tabular}{|c|c|c|c|c|c|c|c|c|}
\hline \multirow[t]{2}{*}{ Scenario } & \multicolumn{2}{|c|}{ No. DVs } & \multirow{2}{*}{$\begin{array}{l}\text { Objective } \\
\text { Function }\end{array}$} & \multicolumn{3}{|c|}{ Terms in the objective function } & \multicolumn{2}{|c|}{$\begin{array}{l}\text { No. elements in the } \\
\text { solution }\end{array}$} \\
\hline & Nodes & Lines & & Floods & STs & Pipes & STs & Pipes \\
\hline 1 & 0 & 35 & 791,214 & 24,753 & 0 & 766,461 & 0 & 21 \\
\hline 2 & 35 & 0 & 273,455 & 5,392 & 268,063 & 0 & 6 & 0 \\
\hline 3 & 35 & 35 & 268,292 & 20,238 & 230,087 & 17,968 & 4 & 4 \\
\hline 4 & 15 & 15 & 245,547 & 8,353 & 213,133 & 24,061 & 4 & 5 \\
\hline 5 & 15 & 8 & 213,981 & 12,701 & 186,353 & 14,927 & 3 & 3 \\
\hline
\end{tabular}

Comparing the solutions that use joint rehabilitation of pipes and STs, it is observed that the reduction of the SS significantly improves the solutions. That is, prelocation of STs and pre-selection of conductions reduces the SS in an amount that allows a better exploration. Therefore, according to Table 6, the best solution is the one proposed by scenario 5, which considers the installation of $3 \mathrm{ST}$ s and the replacement of 3 pipelines. As it is observed, the SSR between scenario 3 and scenarios 4 and 5 it is of many orders of magnitude, which helps to explain the improvement in the solutions.

By reducing the number of DVs, it would have been expected worse solutions due to the reduction of degrees of liberty. But given the limitations of heuristics algorithms, this reduction permits a better exploration of a reduced SS. Additionally, this open the perspective to a iterative process.

The methodology used assesses the flood economically. Therefore, the solutions of scenarios 4 and 5 present the following flood costs: 8,353 $€$ and $12,701 €$ respectively. This represents $3.2 \%$ and $5.9 \%$ respectively. These flood costs correspond to nodes whose flooding level does not exceed $1.5 \mathrm{~cm}$. However, from the point of view of the function defined in Equation (10), any level of flooding has an associated cost.

Based on Equation (9), the flooding level of each flooding node has been calculated. The corresponding flood damage cost has been obtained for each node considering the Equation (10). Additionally, Tables 7 and 8 present the results of the flooding nodes for scenarios 4 and 5. As it can be seen, the flood damage cost is not zero. However, both flood volumes $\left(52.77\right.$ and $75.78 \mathrm{~m}^{3}$ ) and flood levels are very low. Therefore, from a practical point of view it can be considered that the solutions are acceptable. To differentiate the flooding level of solutions obtained and the depth $\left(y_{\max }\right)$ that is used to characterize the damage considered as irreparable the notation $y_{\max }$ is used. 
Table 7. Flooding results in scenario 4.

\begin{tabular}{ccccc}
\hline Node & Flood volume $\left(\mathrm{m}^{3}\right)$ & Flood area $\left(\mathrm{m}^{2}\right)$ & $\mathrm{y}_{\max }(\mathrm{m})$ & $\mathrm{C}(€)$ \\
\hline N10 & 3.77 & 700 & 0.013 & 307.94 \\
N32 & 12.96 & 1,500 & 0.010 & $1,680.29$ \\
N33 & 36.04 & 3,030 & 0.009 & $6,364.57$ \\
TOTAL & 52.77 & & & $8,352.80$ \\
\hline
\end{tabular}

Table 8. Flooding results in scenario 5.

\begin{tabular}{ccccc}
\hline Node & Flood volume $\left(\mathrm{m}^{3}\right)$ & Flood area $\left(\mathrm{m}^{2}\right)$ & $\mathrm{y}_{\operatorname{maxf}}(\mathrm{m})$ & $\mathrm{C}(€)$ \\
\hline N02 & 12.82 & 1,240 & 0.013 & $3,024.66$ \\
N03 & 10.82 & 1,080 & 0.010 & $1,619.42$ \\
N32 & 12.96 & 1,500 & 0.009 & $1,681.56$ \\
N33 & 36.08 & 3,030 & 0.012 & $6,775.01$ \\
TOTAL & 75.78 & & & $12,700.64$ \\
\hline
\end{tabular}

Figure 15 presents the location of the STs obtained in scenario 5, as well as their size. Also, the flooded nodes are represented (blue nodes). Additionally, the figure represents the lines that have been necessary to modify and the size of the new conduits. It should be noted that in the case of conduits P04 and P10, the solution obtained involves the installation of a diameter smaller than the original one. This clearly indicates the need to install in these sections a resistant element (a gate or an orifice) that introduces a head loss equivalent to the one that involves the installation of the new smaller diameter. In other words, some hydraulic control is advisable. 


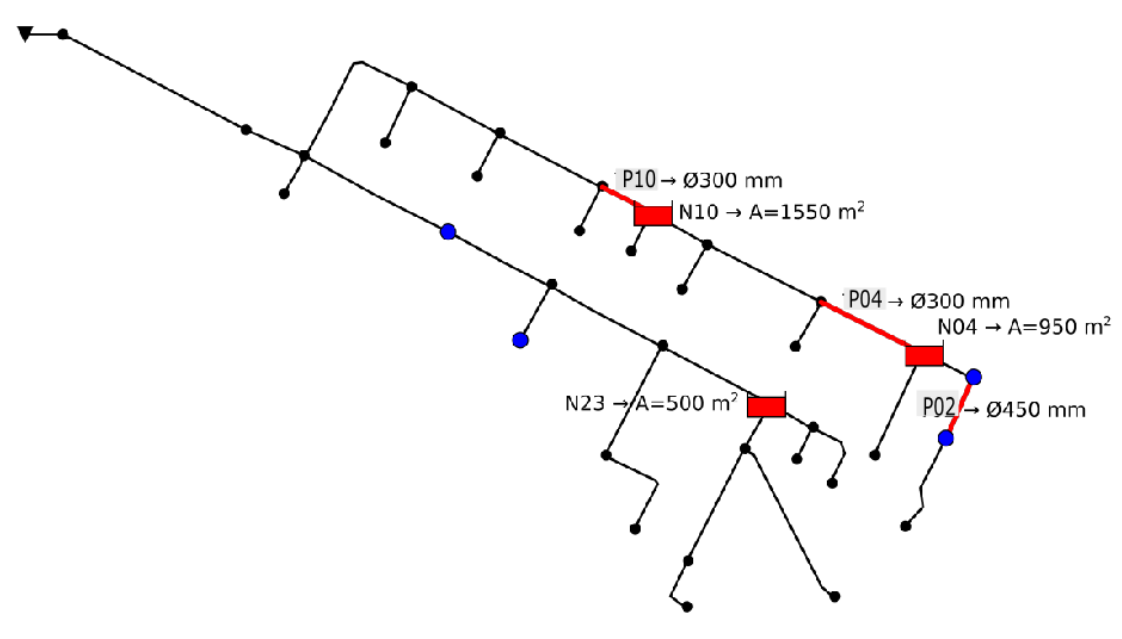

Figure 15. Representation of STs installed and pipes to replace according to scenario 5 results.

The reduction in the number of DVs allows a better exploration of the SS, which means the smaller the number of decision variables, the better the solution found. However, reducing the number of DVs entails another effect. Simulations performed with large numbers of DVs cause a large dispersion of solutions, while solutions obtained with fewer DVs offer a much narrower range of solutions. Thus, Figure 16 represents a comparison of the solution variability range offered in scenarios 3, 4 and 5 .

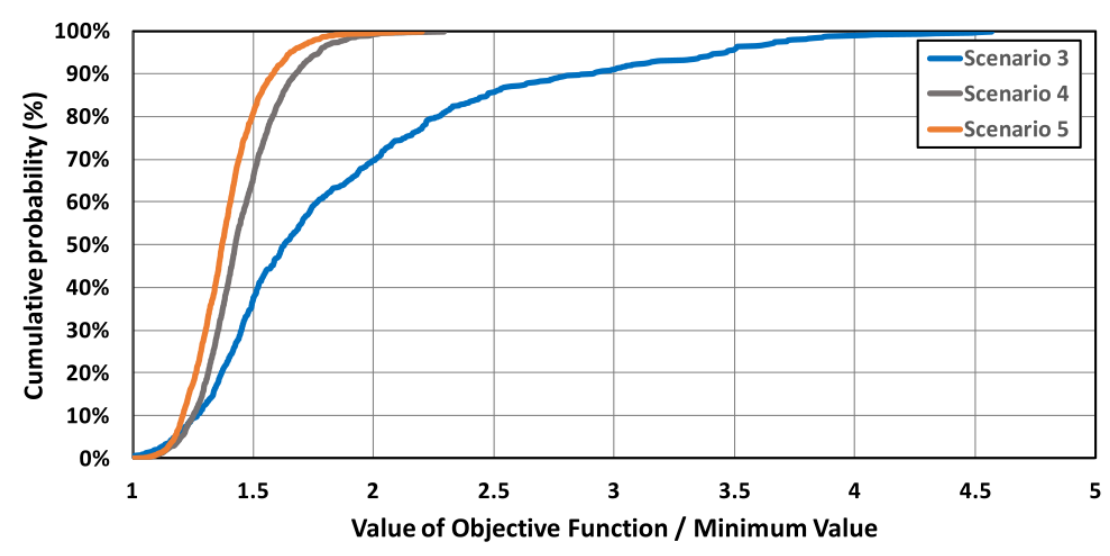

Figure 16. Comparison between the whole problem results and methodology application results. 
Figure 16 shows on the $\mathrm{X}$-axis the relation between the value of the objective function in a simulation and the minimum global value for this scenario. On the $\mathrm{Y}$-axis is represented the frequency of the different solutions obtained with respect to the minimum value obtained. That is, the more vertical the curve, the greater concentration of solutions. On the contrary, if the slope of the curve is smaller, it indicates that there is a greater dispersion of the solutions. These results were obtained after thousands of simulations of scenarios 3,4 and 5. To validate the SSR methodology, a sensitivity analysis was performed.

\subsection{Sensitivity analysis of the SSR}

The main uncertainty is whether the SSR methodology could affect the final solution. It must be borne in mind that STs pre-location and conduits pre-selection were performed using the PGA algorithm with a population size $N_{p o p}=100$ and a termination criterion $N_{g e n}=100$. In order to validate the process, a sensitivity analysis of the prelocation of STs and pre-selection of conduits has been carried out. The process of reducing the SS was repeated with different values of $N_{p o p}$ and $N_{g e n}$. The different values of the population size were $35,50,75,100$ and 300 elements, while the values used as finalization criteria were 50,100 and 150 generations without a change in the value of the objective function. The results obtained are shown in the following figures. In Figure 17 , the nodes that could potentially be a ST location are collected for each combination of values of $N_{p o p}$ and $N_{g e n}$. On the other hand, Figure 18 shows the lines potentially replaceable. In both cases, the node or line selected has been indicated with an $\mathrm{X}$ in the corresponding cell. 
Id of the nodes in which a storage structure is installed

\begin{tabular}{|c|c|c|c|c|c|c|c|c|c|c|c|c|c|c|c|c|c|c|c|c|c|c|c|c|c|c|c|c|c|c|c|c|}
\hline \multicolumn{3}{|c|}{$\mathrm{N}_{\text {pop }} \mathrm{N}_{\text {gen }} 1$} & 2 & 3 & \begin{tabular}{l|l}
45 \\
\end{tabular} & \begin{tabular}{l|l}
5 & 6 \\
\end{tabular} & \begin{tabular}{l|l}
67 \\
\end{tabular} & 7 & 8 8 & 9 & 10 & 11 & 12 & \begin{tabular}{l|l}
13 & 1 \\
\end{tabular} & \begin{tabular}{l|l}
14 & 1 \\
\end{tabular} & \begin{tabular}{l|l|}
5 & 1 \\
\end{tabular} & \begin{tabular}{l|l|}
66 & 17 \\
\end{tabular} & 18 & 19 & \begin{tabular}{l|l}
20 & 2 \\
\end{tabular} & 2122 & $\begin{array}{ll}223 \\
\end{array}$ & 242 & \begin{tabular}{|l|l|}
25 & 2 \\
\end{tabular} & \begin{tabular}{l|l}
6 & 27 \\
\end{tabular} & 28 & 293 & \begin{tabular}{l|l}
30 & 3 \\
\end{tabular} & 313 & \begin{tabular}{l|l}
2 & 3 \\
\end{tabular} & \begin{tabular}{l|l}
33 & 34 \\
\end{tabular} & 35 \\
\hline \multirow{3}{*}{35} & 50 & & $\mathbf{X}$ & $\mathbf{X}$ & \begin{tabular}{l|l}
$\mathrm{X}$ & $\lambda$
\end{tabular} & \begin{tabular}{l|l}
$X$ & $x$
\end{tabular} & \begin{tabular}{l|l}
$X$ & $\lambda$
\end{tabular} & $x$ & & $\mathrm{x}$ & $\mathrm{X}$ & $\mathbf{X}$ & $\mathbf{X}$ & & $X$ & & & $X$ & & & & $X$ & & & & & & $X$ & $\bar{x}$ & $\mathrm{X}$ & $X$ & \\
\hline & 100 & $x$ & $\mathbf{X}$ & $\mathbf{X}$ & $X$ & $x$ & \begin{tabular}{l|l}
$\mathrm{X}$ &
\end{tabular} & $\bar{X}$ & & $\mathbf{X}$ & $\mathrm{X}$ & $\mathbf{X}$ & $\mathbf{X}$ & & $X$ & & & $\mathbf{X}$ & & & & $X$ & & & & & & & $X$ & $\mathrm{X}$ & $\mathrm{X}$ & \\
\hline & 150 & $\mathrm{x}$ & $x$ & $\mathrm{X}$ & \begin{tabular}{l|l}
$x$ & $\lambda$ \\
\end{tabular} & \begin{tabular}{l|l}
$x$ & $x$ \\
\end{tabular} & \begin{tabular}{l|l}
$x$ & $\lambda$ \\
\end{tabular} & $x$ & & & $x$ & $\mathrm{X}$ & $x$ & & & & & $\mathrm{X}$ & & & & $\mathrm{X}$ & & & & & & & & \begin{tabular}{l|l}
$x$ & $x$ \\
\end{tabular} & \begin{tabular}{l|l}
$x$ & $x$ \\
\end{tabular} & \\
\hline \multirow{3}{*}{50} & 50 & $\mathrm{x}$ & $\mathbf{x}$ & $\mathrm{x}$ & \begin{tabular}{l|l}
$x$ & $\lambda$ \\
\end{tabular} & \begin{tabular}{l|l}
$x$ & $x$ \\
\end{tabular} & \begin{tabular}{l|l}
$x$ & $\lambda$ \\
\end{tabular} & $x$ & $X$ & & $X$ & $\mathbf{X}$ & $\mathrm{X}$ & $X$ & & $x$ & $X$ & $\mathrm{X}$ & & & & $x$ & & & & & & & & & \begin{tabular}{l|l}
$X$ & $x$ \\
\end{tabular} & \\
\hline & 100 & $\mathrm{x}$ & $\begin{array}{ll}x \\
\end{array}$ & $X$ & $X$ & $X$ & $X$ & $x$ & \begin{tabular}{l|l}
$\mathbf{x}$ & ) \\
\end{tabular} & $X$ & $X$ & $\mathrm{X}$ & $X$ & & & $X$ & $x$ & $\mathrm{X}$ & & & & $\mathrm{X}$ & & & & & & & & & $X$ & \\
\hline & 150 & & $\mathbf{X}$ & $\mathbf{X}$ & $\mathrm{X}$ & $X$ & \begin{tabular}{l|l}
$x$ & $\lambda$
\end{tabular} & $x$ & $\begin{array}{lll}X & \end{array}$ & $\mathbf{X}$ & $x$ & $\mathbf{X}$ & $\mathbf{X}$ & & & & & & & & & $X$ & & & & & & & & $\mathrm{X}$ & X & \\
\hline \multirow{3}{*}{75} & 50 & $x$ & $\mathrm{X}$ & & \begin{tabular}{l|l}
$x$ & $\lambda$ \\
\end{tabular} & \begin{tabular}{l|l}
$x$ & $x$ \\
\end{tabular} & $\bar{x}$ & $x$ & \begin{tabular}{l|l}
$x$ & ) \\
\end{tabular} & $\mathrm{X}$ & $x$ & $X$ & & $X$ & & & & $\mathrm{X}$ & & & & $X$ & & & & & & & & & \begin{tabular}{l|l}
$X$ & $x$ \\
\end{tabular} & \\
\hline & 100 & & $\mathrm{X}$ & & \begin{tabular}{l|l}
$x$ & $\lambda$ \\
\end{tabular} & \begin{tabular}{l|l}
$x$ & $x$ \\
\end{tabular} & $x>$ & $x$ & \begin{tabular}{l|l}
$x$ & 3 \\
\end{tabular} & $\mathbf{X}$ & $x$ & $X$ & & $X$ & & & & $\mathrm{X}$ & & & & $x$ & & & & & & & & \begin{tabular}{l|l}
$x$ & $\lambda$ \\
\end{tabular} & \begin{tabular}{l|l}
$X$ & $X$ \\
\end{tabular} & \\
\hline & 150 & $\mathrm{x}$ & $x$ & & \begin{tabular}{l|l}
$x$ & $\lambda$ \\
\end{tabular} & \begin{tabular}{l|l}
$x$ & $x$ \\
\end{tabular} & \begin{tabular}{l|l}
$\mathbf{X}$ & $\lambda$ \\
\end{tabular} & $x$ & \begin{tabular}{l|l}
$x$ & \\
\end{tabular} & $\mathbf{X}$ & $x$ & & & & & & & $\mathrm{x}$ & & & & $\mathrm{X}$ & & & & & & & & $x$ & $X$ & \\
\hline \multirow{3}{*}{100} & 50 & $x$ & $\mathbf{x}$ & \begin{tabular}{l|l}
$x$ & $\lambda$ \\
\end{tabular} & $X$ & $x$ & $x$ & $x$ & \begin{tabular}{l|l}
$x$ \\
\end{tabular} & $\mathrm{X}$ & $\mathrm{x}$ & $\mathbf{x}$ & & & $x$ & & & $\mathrm{X}$ & & & & $\mathrm{X}$ & & & & & & & & \begin{tabular}{l|l}
$x$ & $\lambda$ \\
\end{tabular} & \begin{tabular}{l|l}
$X$ & $x$ \\
\end{tabular} & \\
\hline & 100 & $\mathbf{x}$ & $\mathbf{X}$ & \begin{tabular}{l|l}
$\mathbf{X}$ & $\lambda$
\end{tabular} & $x$ & $X$ & \begin{tabular}{l|l}
$X$ & $\lambda$ \\
\end{tabular} & $x$ & $X$ & & $\mathbf{x}$ & $\mathbf{X}$ & & & $X$ & & & $\mathbf{X}$ & & & & $X$ & & & & & & & & $\begin{array}{lll}X & \lambda\end{array}$ & \begin{tabular}{c|c}
$\mathbf{X}$ \\
\end{tabular} & \\
\hline & 150 & & $\mathbf{x}$ & \begin{tabular}{l|l}
$x$ & $\lambda$ \\
\end{tabular} & \begin{tabular}{l|l}
$x$ & $\lambda$ \\
\end{tabular} & \begin{tabular}{l|l}
$x$ & $x$ \\
\end{tabular} & $x$ & $x$ & $X$ & & $X$ & $\mathbf{X}$ & & & & & & & & & & $\mathrm{X}$ & & & & & & & & $x$ & $x$ & \\
\hline \multirow{3}{*}{300} & 50 & & $x$ & \begin{tabular}{l|l}
$x$ & $\lambda$ \\
\end{tabular} & $X$ & $X$ & \begin{tabular}{l|l}
$x$ \\
\end{tabular} & $x$ & & & $x$ & & & & & & & $\mathrm{X}$ & & & & $x$ & & & & & & & & & \begin{tabular}{l|l}
$X$ & $X$ \\
\end{tabular} & \\
\hline & 100 & & $\mathbf{x}$ & & $X$ & $X$ & $\begin{array}{lll}x & \\
\end{array}$ & $x$ & $X$ & & $x$ & $\mathrm{X}$ & & & & & & & & & & $X$ & & & & & & & & & $X$ & \\
\hline & 150 & & $\mathbf{X}$ & & $X$ & $x$ & $\bar{X}$ & & $X$ & & $\mathbf{x}$ & $\mathbf{X}$ & & & & & & & & & & $X$ & & & & & & & & & $\mathrm{X}$ & \\
\hline
\end{tabular}

Scenario

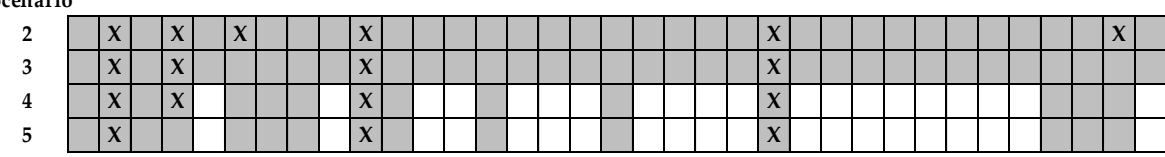

Figure 17. Sensitivity analysis results for pre-located STs with different $N_{\text {pop }}$ and $N_{G e n}$.
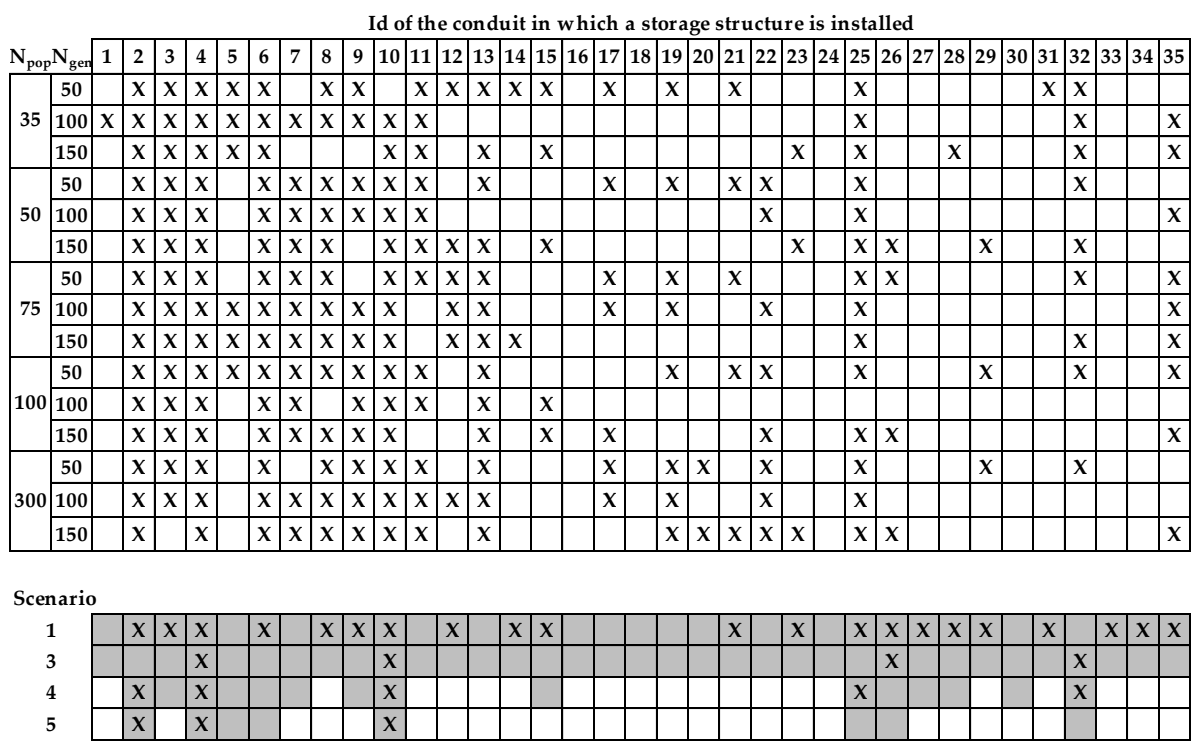

Figure 18. Sensitivity analysis results for pre-selecting conduits with different $N_{\text {pop }}$ and $N_{\text {Gen. }}$. 
Scenario 1 cannot exist in Figure 17. In the same way, scenario 2 cannot exist in Figure 18 because Figure 17 concerns STs pre-location and Figure 18 concerns pipes pre-selection.

The sensitivity analysis of Figures 17 and 18 validates the SSR methodology for single-objective optimization based on the pre-location of STs and the pre-selection of conduits. In the lower part of Figure 17, the DVs used in each scenario are indicated by a shaded cell, and $\mathrm{X}$ indicates the nodes that finally provide a solution for the installation of a ST. The nodes that finally appear as solutions in the scenarios are those that had been selected mostly in the process of pre-selection of STs. In short, regardless the value of $N_{p o p}$ and $N_{g e n}$ the preselected nodes would have been almost the same, and in any case those that appear in the final solutions of scenarios 3, 4 and 5 would have always been selected.

Something similar happens in the case of pre-selection of conduits. Figure 18 shows the results of the sensitivity analysis and the results of scenarios 1, 3, 4 and 5. As in Figure 17, the DVs used are indicated as shaded cells, and the lines that are finally replaced are indicated with an X. The results show that the lines selected for different values of $N_{p o p}$ and $N_{g e n}$ are almost the same. That is, selected lines are those that are finally found in the final solutions of scenarios 3, 4 and 5. Moreover, $N_{p o p}$ and $N_{g e n}$ parameters have no influence on the pre-location of STs or on the pre-selection of pipes. Therefore, the SSR methodology can be considered as reliable.

\subsection{Application of MO optimization to E-Chicó.}

The MO optimization presented in Section 4.4 is applied to E-Chicó.

Three different rehabilitation scenarios were performed depending on the selection of the DVs:

- Scenario 1: 35 conduits.

- Scenario 2: 35 STs.

- Scenario 3: 35 STs and 35 conduits.

These simulations were performed with a population size of 200 individuals and number of generations 10000 for all the three scenarios.

The results obtained after the application of modified NSGA-II optimization methodology to E-Chicó drainage network are presented on Figure 19. The Pareto fronts of the three considered rehabilitation scenarios are presented. It also shows that the scenario 3 presents better results than scenarios 1 and 2. Even though this combined scenario represents a bigger problem (70 decision variables versus 35 of scenarios 1 and 2 ), the combination of two different strategies leads to better results. 


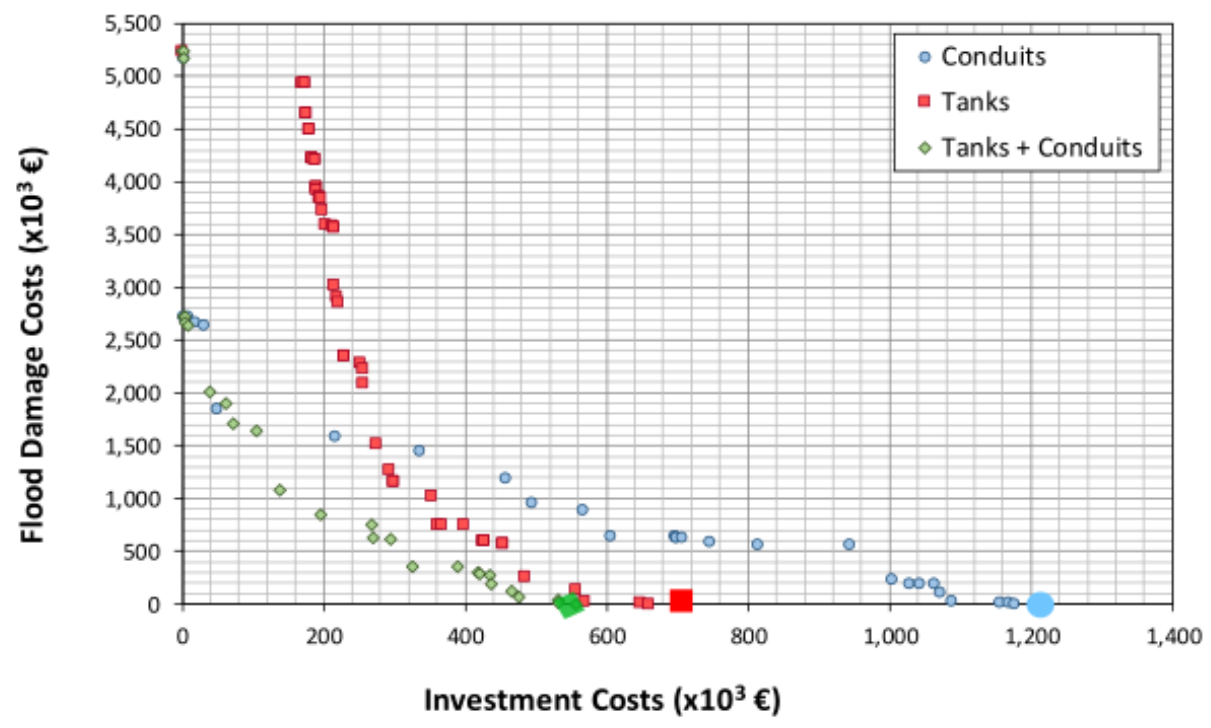

Figure 19. Pareto front representation of 3 different scenarios.

The aim of this part of the work was to show that the combined use of pipes substitution and STs installation for MO optimization allows the obtention of better results than the optimization of each of them separately.

The NSGA-II presents a set of feasible solutions instead of a single one. The decision about the best solution depends on several factors: budget availability, risk level, administrative regulations, etc. As an example, the solution for the case of unlimited budget availability is presented. If there are no investment limitations, the solution will look for a scenario with no flooding. This scenario corresponds to the horizontal axis of Figure 19. The solution for zero flooding needs an investment of $1,213,453 €$ in pipes renewal or $719,366 €$ in storage units. According with the MO methodology, the problem can be solved with an investment for conduits and STs. In this case, it is only necessary to invest $517,559 €$.

Another indicator used to evaluate the solution was the standard deviation of the crowding distance in the first Pareto front. The dependence of this parameter with the population size was also studied. Figure 20 shows that there is a strong dependency between both parameters. 


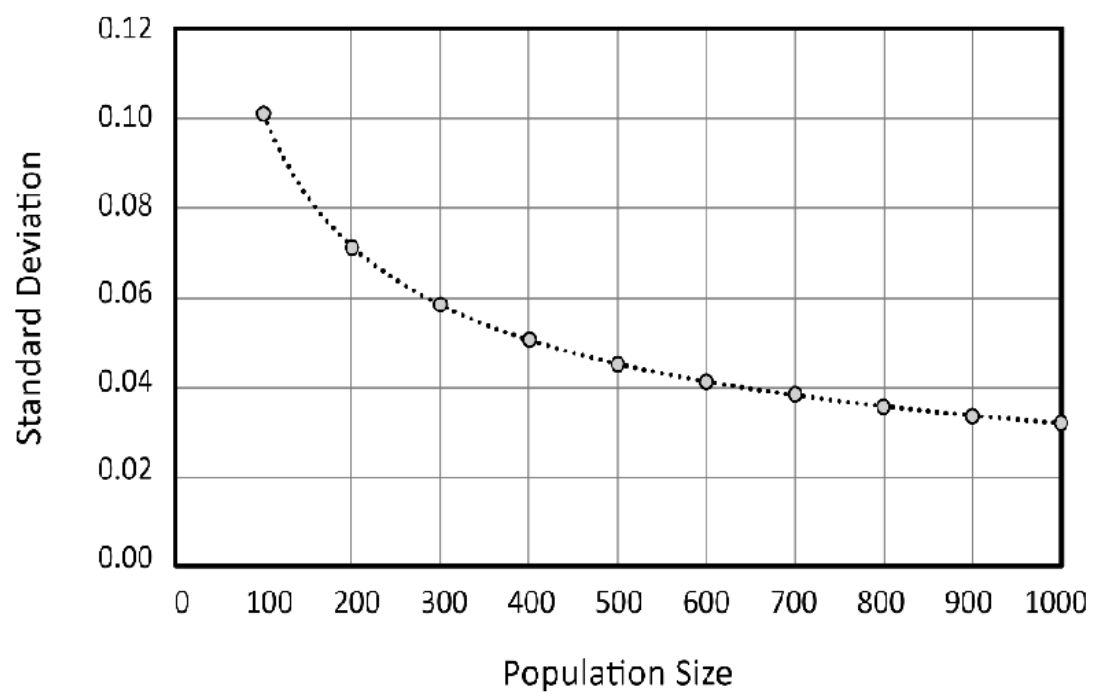

Figure 20. Standard deviation of first Pareto front as a function of population size in the final solution for scenario $3(35 T+35 C)$.

This relation might be represented by a power function with an extremely high correlation. This relation allows deciding the minimum population for a desired distribution of individuals in the Pareto front. In fact, there is a value to whom it would tend asymptotically if the distribution were perfect and it can be calculated.

The result obtained for MO optimization confirms the conclusion of SO optimization. That is, the rehabilitation considering STs installation and pipes substitution provides better results than any of the two strategies used separately.

The use of damage functions to evaluate the effect of flooding allows comparing the investment and the damage even though the first are expenses that depend on the probability of occurrence of the rainfall. Additionally, investment costs are paid at the beginning and damage costs are paid during the lifetime of the system.

\subsection{Application of the proposed methodology for MO optimization}

In order to apply the proposed methodology presented in Section 4.6, a part of the drainage network of Medellin city (Colombia) was used. The part of the drainage network studied is generically known as Ayurá (Figure 21) district. The network discharge in the Medellín River which cross the city from South to North. The network is extended over 22.5 ha and is divided into 83 hydrological sub-catchments for 73 nodes and 86 circulars conduits with diameters from 200 to $1050 \mathrm{~mm}$. The difference level between the highest and the lowest point is $15.61 \mathrm{~m}$. The network works completely by 
gravity. Even though the methodology has been applied to various networks, Ayurá has been selected for this part of the thesis due to the elevated number of conduits and nodes and to the fact that Ayurá is a looped network.

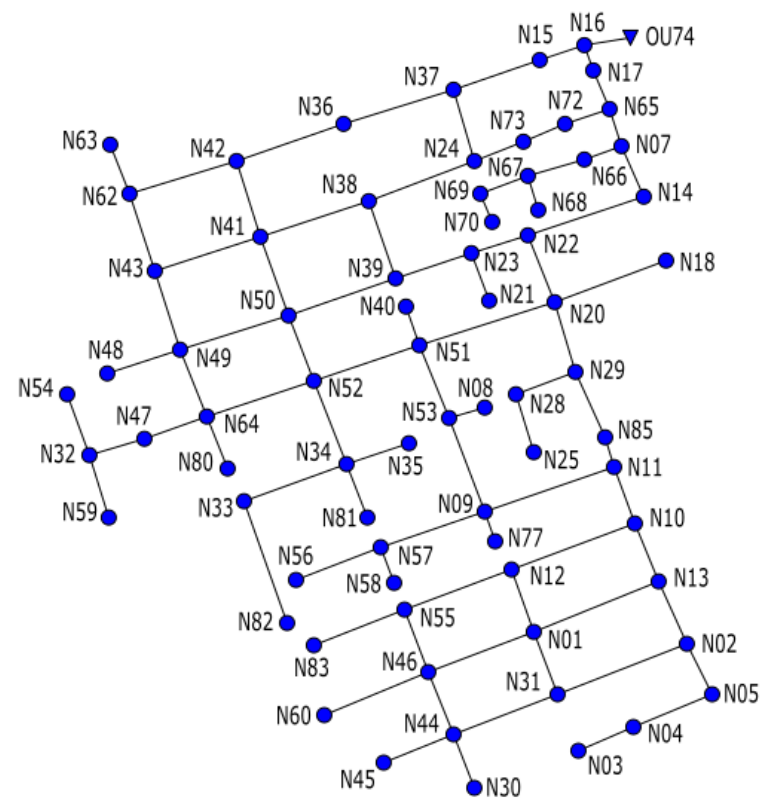

Figure 21. Representation of Ayurá drainage network.

From the first hydraulic analysis performed in SWMM, the total flooding volume of the network is about $4,271 \mathrm{~m}^{3}$ which represents $27.14 \%$ of the total generated runoff $\left(15,735 \mathrm{~m}^{3}\right)$ for the selected rainfall.

To sum up, the preliminary analysis of the network shows that it is unable to drain the selected project rain.

Three different rehabilitation scenarios were performed depending on the selection of DVs. Scenarios 4 and 5 were obtained after application of SSR to the complete network.

- Scenario 3: 73 STs and 86 conduits

- Scenario 4: 29 STs and 47 conduits

- Scenario 5: 29 STs and 39 conduits

To validate that the SSR methodology improves the results in SO optimization, a SO optimization was applied to the complete network. The results are presented in Table 9 although this is not the objective of the methodology. 
Table 9: Results of SSR methodology to Ayurá for SO optimization process

\begin{tabular}{ccccccccccc}
\hline & $\begin{array}{c}\text { No. Decisions } \\
\text { Variabless }\end{array}$ & $\begin{array}{c}\text { Objective } \\
\text { Scenario }\end{array}$ & \multicolumn{2}{c}{ Costs of the objective function } & \multicolumn{2}{c}{$\begin{array}{c}\text { No. elements in } \\
\text { the solution }\end{array}$} & $\begin{array}{c}\text { Problem } \\
\text { size }\end{array}$ \\
& Nodes & Lines & Function & Floods & STs & Pipes & ST & Pipes & \\
\hline 3 & 73 & 86 & 381,950 & 6,335 & 215,828 & 159,787 & 5 & 33 & $1.49 \cdot 10^{237}$ \\
4 & 29 & 47 & 351,879 & 3,983 & 215,769 & 132,127 & 5 & 33 & $1.45 \cdot 10^{112}$ \\
5 & 29 & 39 & 347,982 & 3,541 & 244,288 & 100,153 & 6 & 27 & $9.53 \cdot 10^{100}$ \\
\hline
\end{tabular}

Table 9 presents the results obtained for SO optimization of scenario 3 and scenarios 4 and 5. It also shows how decreases the SS of the problem while reducing DVs number. It can be observed that for SO optimization, scenarios 4 and 5 provide better results than scenario 3 .

Table 9 shows that floods are reduced in scenario 5 where there are more installed STs than scenario 3. The SSR provides a better exploration capacity to the optimization algorithm and increase to possibility to find the optimal solution.

For the second part of the methodology, the three scenarios undergo a MO optimization through the algorithm NSGA-II. For the MO optimization, the simulations were performed with a population size of 200 individuals. The results obtained after the application of modified NSGA-II optimization methodology to Ayurá drainage network are presented on Figure 22. 


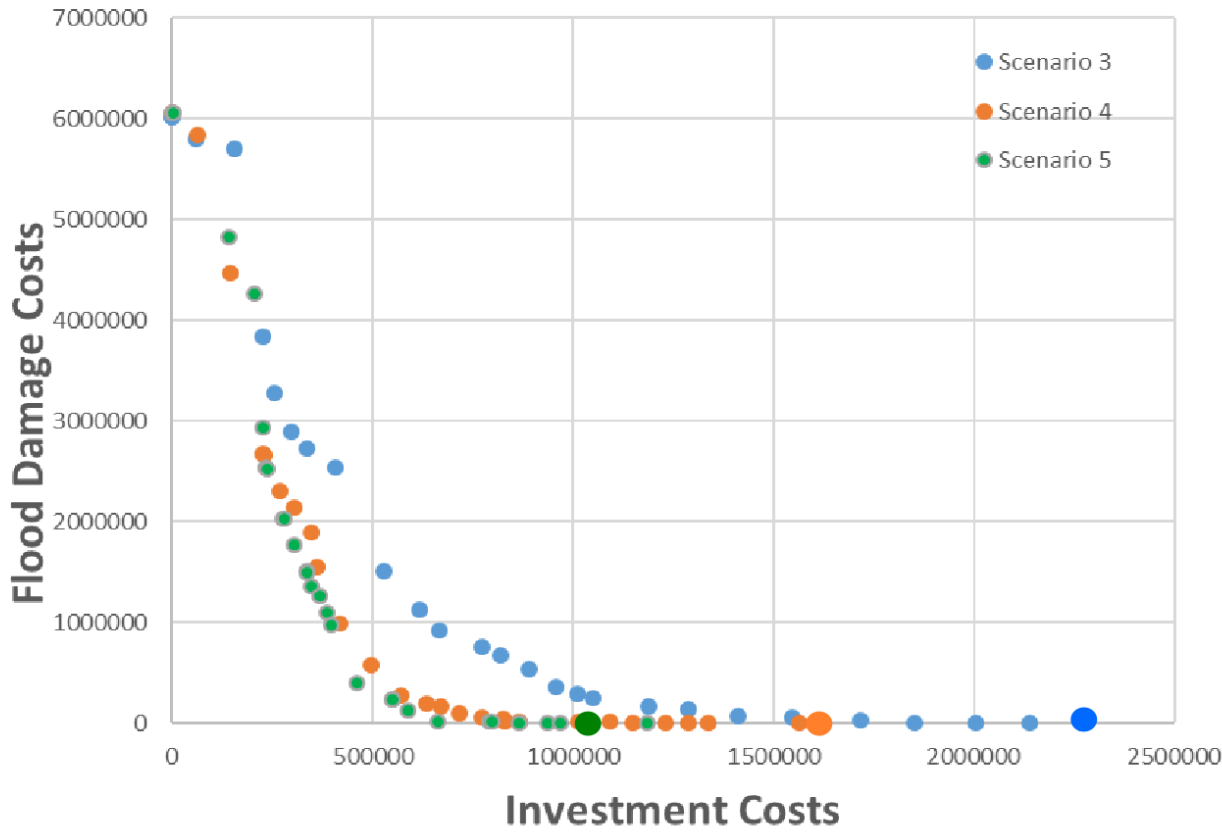

Figure 22. Pareto front representation of 3 different scenarios.

Figure 22 shows Pareto fronts of three different scenarios considering STs installation and pipes substitution.

The solution for zero flooding needs an investment of 2,269,492 € for scenario 3. or $1,607,890.49 €$ for scenario 4 . According with the methodology presented in this part of the thesis, the problem can be solved with an investment for conduits and STs of $1,183,543.31 €$ for the scenario 5 .

Actions that should be taken for the zero-flooding solution of scenario 5 are presented on Figure 23. Locations of STs to install and pipes to be substituted are presented. 


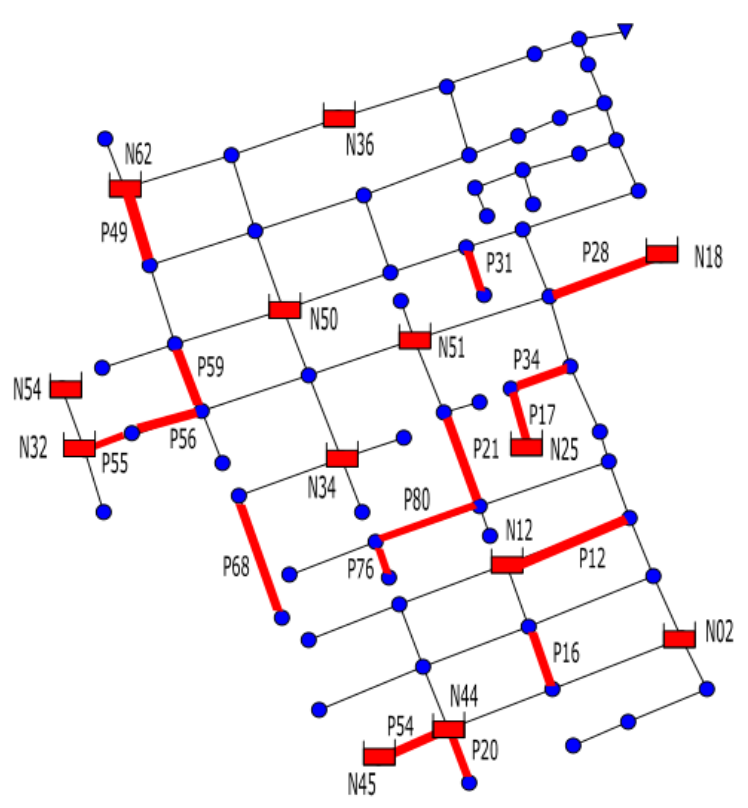

Figure 23. Representation of storm tanks installed and pipes to substitute according to scenario 5 zero-flooding solution.

Table 10 presents the list of pipes to be substituted for scenario 5 zero-flooding solution and their corresponding diameters.

Table 10: New pipe diameters according to scenario 5 zero-flooding solution.

\begin{tabular}{ccccccccc}
\hline Pipes & P12 & P16 & P17 & P20 & P21 & P28 & P31 & P34 \\
& & & & & & & & \\
D(mm $)$ & 300 & 350 & 600 & 600 & 300 & 3000 & 300 & 300 \\
\hline Pipes & P49 & P54 & P55 & P56 & P59 & P68 & P76 & P80 \\
D(mm $)$ & 350 & 3000 & 300 & 3000 & 300 & 350 & 400 & 350 \\
\hline
\end{tabular}

Table 11 presents the list of nodes where STs should be installed and their corresponding base areas for scenario 5 zero-flooding solution. 
Table 11: New storm tanks areas according to the scenario 5 zero-flooding solution.

\begin{tabular}{lccccccccccccc}
\hline Nodes & $\mathrm{N} 02$ & $\mathrm{~N} 12$ & $\mathrm{~N} 18$ & $\mathrm{~N} 25$ & $\mathrm{~N} 32$ & $\mathrm{~N} 34$ & $\mathrm{~N} 36$ & $\mathrm{~N} 44$ & $\mathrm{~N} 45$ & $\mathrm{~N} 50$ & $\mathrm{~N} 51$ & $\mathrm{~N} 54$ & $\mathrm{~N} 62$ \\
$\mathrm{~A}\left(\mathrm{~m}^{2}\right)$ & 1400 & 1450 & 450 & 1850 & 1250 & 150 & 1100 & 800 & 800 & 1450 & 650 & 100 & 250 \\
\hline
\end{tabular}

Here, the results obtained for scenario 5 zero-flooding solution of MO optimization are analyzed. From the 16 pipes to replace, 13 pipes have an increase of diameters, while pipes P12, P55 and P80 diameters are smaller than the original ones. In these parts of the network, it is reasonable to install a dissipation element (an orifice or a gate) to introduce a head loss equivalent to the one that involves the installation of the new smaller diameter. This result shows the necessity to include the hydraulic control in drainage networks rehabilitation process.

Address the rehabilitation in monetary units permits to assess the flood damages and select the corresponding investments to mitigate them. Pareto fronts provided set of optimal solutions that can help drainage managers to select the ones corresponding to their budget, the risk assessment or the network design criteria.

In a context where time optimization is a new challenge in water resources management, this thesis shows that problem size reduction or SSR is important to save time and investments in presence of an optimization problem. 


\section{Chapter 6}

\section{Conclusions and future developments}

\subsection{Introduction}

The main objective of this $\mathrm{PhD}$ thesis is to propose a drainage networks rehabilitation methodology. The methodology is based on STs installation and pipes substitution. The methodology considers an SSR technique. This objective was divided in specific objectives that have been satisfactorily achieved. Therefore, five papers were published in conferences proceeding and peer review journals.

\subsection{Main contributions and conclusions}

This thesis presents an interesting state of art on the optimal rehabilitation of drainage networks. In Appendices (I, II, III, IV and V) there is a discussion on the evolution of rehabilitation methodologies. The strengths and limits of most discussed methodologies are presented. The base of this thesis are the limits observed in the rehabilitation of drainage networks. 
Extreme rainfall events combined to urbanization is one of the major cause of floods. Their negative effects could be reduced by improving the network using an adequate adaptation methodology.

Generally, floods are characterized by their volume. In this thesis, they are characterized by the highest level reached by water. For this purpose, a flood damage costs function that converts hydraulic values into monetary units was formulated and proposed. To adequately present the rehabilitation problem, the investment costs function is also addressed in monetary units.

There were two rehabilitation scenarios for drainage networks rehabilitation: pipes substitution and STs installation. A third scenario has been formulated and proposed: STs installation combined with pipes substitution. Results obtained for SO optimization shown that STs installation combined with pipes substitution provides better results than any strategy implemented separately.

Due to the difficulties to sum investment costs and flood damage costs, A MOEA algorithm was proposed to solve the issue. A NSGA-II including an additional elitism was used to perform drainage networks rehabilitation. Two individuals were introduced in each generation: the zero-investment solution and the maximum investment solution.

Results obtained from MO optimization showed that the combined use of pipes substitution and STs installation provide better results than any strategy implemented separately. It confirms therefore the result obtained for SO optimization.

The use of damage functions to evaluate the effect of flooding allows comparing the investment and the damage even though the first are expenses that depend on the probability of occurrence of the rainfall.

Pareto front provides a set of feasible solutions that will help decision makers select the best option. The rehabilitation problem is addressed in monetary units. So, the tool proposed in this thesis can be used by network managers in municipalities and industry.

One of the most important contributions in this thesis is the proposition of an SSR methodology. As drainage network rehabilitation is computationally time consumer based on the size of the SS and the presence of many local minima where the solution in various cases is caught up, an SSR methodology has been proposed to solve the problem encountered. SSR methodology is based on the reduction of the number of DVs (nodes where STs can potentially be installed and the lines in which there could potentially be a change in diameter) and the reduction of the variation range of DVs (discretization in storm tanks dimensioning and reduction of the candidate diameters that can be selected). The methodology is composed of two parts:

- The pre-location of STs that allows to select nodes where can potentially be installed STs at the end of the optimization process.

- The pre-selection of possible pipes substitution that allows to select the lines where pipes could probably be substituted at the end of the optimization process. 
The implementation of SSR methodology to drainage networks rehabilitation allows to do the following observations:

- The number of local minima was reduced due to the reduction of the SS.

- The optimization algorithm showed a better exploration capacity of the SS.

- Better values of objective function were obtained.

For SO optimization, the rehabilitation of drainage networks considering SSR provides better results than the rehabilitation of the whole problem.

In this thesis thousands of simulations were performed for the whole network and for the scenarios obtained after the application of SSR methodology. It was observed that results of the whole network rehabilitation were dispersed. On the contrary, results of scenarios obtained after application of SSR were more concentrated. SSR methodology allows to concentrate results of drainage networks rehabilitation.

A sensitivity analysis was carried out to validate the SSR methodology. The aim was to show that reduction of DVs does not affect the final solution of the optimization process. The sensitivity analysis validated SSR methodology based on several simulations that were run for different population sizes and number of generations without change in the value of the objective function. Results showed that the nodes and the lines selected for different values of $N_{p o p}$ and $N_{g e n}$ were almost the same. Meaning that they have no influence on the pre-location of STs or on the pre-selection of pipes. Therefore, the SSR is a reliable and effective methodology.

A new methodology for drainage networks rehabilitation finally was proposed. The methodology combines SSR methodology and MO optimization. The results obtained from the application of this methodology showed that MO optimization considering SSR provides better results than the resolution of the whole problem through MO optimization.

Results obtained for various optimization strategies suggested that hydraulic assets such as gate or orifice should be installed to introduce the same head lost that a reduced diameter would have produced. This is known as hydraulic control. Therefore, hydraulic control should be included in drainage network rehabilitation.

\subsection{Future developments}

The present thesis has addressed important problematics and there are some future developments that can be considered as investigation subjects:

- Some results showed that the hydraulic control should be include in drainage network rehabilitation. This opens the possibility to consider hydraulic control during drainage networks rehabilitation. Therefore, it will be necessary to include a gate or an orifice on the output of STs to control the flow and improve STs efficiency.

- It will be interesting to use other algorithms and compare the obtained results. There are many optimization algorithms that can be used to implement the SSR 
and MO optimization. The results provided by the other selected algorithms will be compared to the ones obtained using PGA and NSGA-II.

- Only circular pipes were used in this thesis. A new perspective will be the introduction of other pipe forms in the optimization process. In practice, a drainage network is composed of conduits of different forms. An optimization process considering other forms of conduits will suppose a new equation to calculate investment costs of conduits.

- During the optimization process, the slope remained the same, a necessary development would be the modification of the slope. Changes in slopes of conduits of the network will suppose a reduction of diameters for some conduits.

- STs used in the thesis are in-line, in the future, it is planned the used of off-line STs. The use of off-line STs will help to introduce the real time control (RTC).

- It will be proceeded to the analysis of algorithm optimization parameters.

- Pumps will be included in the optimization process. So, new cost functions will be introduced in the objective functions.

- Finally, the SSR should be improved. It would be made iterative to reduce even more the problem size.

The obtained results in each part of this thesis were satisfactory. So, it is expected that the proposed methodology will be implemented by engineers and network managers to improve their results and reduce their operation time in drainage network rehabilitation process. 


\section{Chapter 7}

\section{Bibliography}

1. Kirshen, P.; Caputo, L., Vogel, R. M.; Mathisen, P.; Rosner A. and Renaud, T. Adapting Urban Infrastructure to Climate Change: A Drainage Case Study. J. Water Resour. Plan. Manag 2015, vol. 141, no. 4, pp. 04014064.

2. Jeong, H.; Ha, S. and Kim, H. Flood Protection Cost Allocation Using Cooperative Game Theory for Adapting Infrastructure to Climate Change. $J$ Water Resour Plan Manag 2018, vol. 144 no. 4, pp. 04018010.

3. Alves, A.; Gersonius, B.; Sanchez, A.; Vojinovic, Z. and Kapelan, Z. Multicriteria Approach for Selection of Green and Grey Infrastructure to Reduce Flood Risk and Increase CO-benefits. Water Resour Manag 2018, vol. 32 no. 7, pp. 2505-2522.

4. De Paola, F.; Giugni M.; Pugliese, F. and Romano, P. Optimal Design of LIDs in Urban Stormwater Systems Using a Harmony-Search Decision Support System. Water Resour Manag 2018, vol. 32 no. 15, pp. 4933-4951.

5. Szewrański, S.; Chrusćinśki, J.; Kazak, J.; Swíader, M.; Tokarczyk-Dorociak, K. and Zmuda, R. Pluvial Flood Risk Assessment Tool (PFRA) for rainwater management and adaptation to climate change in newly urbanised areas. Water 2018, vol. 10 no. 4, pp. 386. 
6. Vermuyten, E.; Meert, P.; Wolfs, V. and Willems, P. Combining Model Predictive Control with a Reduced Genetic Algorithm for Real-Time Flood Control. J Water Resour Plan Manag 2018, vol. 144 no. 2, pp. 04017083.

7. Salinas-Rodriguez, C.; Gersonius, B.; Zevenbergen, C.; Serrano, D. and Ashley, R. A semi risk-based approach for managing urban drainage systems under extreme rainfall. Water 2018, vol. 10 no. 4, pp. 384.

8. Song, Y. H.; Yun, R.; Lee, E. H. and Lee, J. H. Predicting sedimentation in urban sewer conduits. Water 2018, vol. 10 no. 4, pp. 462.

9. Zhang, D.; Martinez, N.; Lindholm, G. and Ratnaweera, H. Manage Sewer InLine Storage Control Using Hydraulic Model and Recurrent Neural Network. Water Resour Manag 2018, vol. 32 no. 6, pp. 2079-2098.

10. Ugarelli, R. and di Federico, V. Optimal Scheduling of Replacement and Rehabilitation in Wastewater Pipeline Networks. J. Water Resour. Plan. Manag. 2010, vol 136, pp.348-356.

11. Sebti, A.; Fuamba, M. and Bennis, S. Optimization Model for BMP Selection and Placement in a Combined Sewer. J. Water Resour. Plan. Manag 2015, pp. 04015068 .

12. Martinez-Solano, F.J.; Iglesias-Rey, P.L; Saldarriaga, J. G. and Vallejo, D. Creation of an SWMM Toolkit for Its Application in Urban Drainage Networks Optimization. Water 2016, vol. 8, no. 6, pp. 1-16.

13. Mora-Melia, D.; Iglesias-Rey, P.L. and Martinez-Solano, F.J.; BallesterosPérez, P. Efficiency of Evolutionary Algorithms in Water Network Pipe Sizing. Water Resour. Manag. 2015, vol. 29, pp. 4817-4831.

14. Deb, K.; Pratap, A.; Agarwal, S.; and T. Meyarivan. A fast and elitist multiobjective genetic algorithm: NSGA-II. IEEE Trans. Evol. Comput. 2002, vol. 6, no. 2, pp. 182-197.

15. Mailhot, A. and Duchesne, S. Design Criteria of Urban Drainage Infrastructures under Climate Change. J. Water Resour. Plan. Manag 2010, vol. 136, no. 2, pp. 201-208.

16. Gulizia, C. and Camilloni, I. Comparative analysis of the ability of a set of CMIP3 and CMIP5 global climate models to represent precipitation in South America. Int. J. Climatol 2015, vol. 35, no. 4, pp. 583-595.

17. Quinn, A. D.; Ferranti, E. J. S.; Hodgkinson, S. P.; Jack, A. C. R.; Beckford, J. and Dora, J. M. Adaptation Becoming Business as Usual: A Framework for Climate-Change-Ready Transport. Infrastructures 2018, vol. 3 no. 2, pp.10.

18. Ma, M.; He, B.; Wan, J.; Jia, P.; Guo, X.; Gao, L.; Maguire, L. and Hong, L. Characterizing the Flash Flooding Risks from 2011 to 2016 over China. Water 2018, vol. 10, no. 6, pp. 704.

19. Driessen, P.; Hegger, D.; Kundzewicz, Z.; van Rijswick, H.; Crabbé, A.; Larrue, C.; Matczak, P.; Pettersson, M.; Priest, S.; Suykens, C. and Raadgever, G. Governance strategies for improving flood resilience in the face of climate change. Water 2018, 10, 1595. 
20. Abraham, D. M.; Wirahadikusumah, R.; Short, T. J. and Shahbahrami, S. Optimization Modeling for Sewer Network Management. J. Constr. Eng. Manag 1998, vol. 124, no. 5, pp. 402-410.

21. Rossman, L.A. StormWater Management Model User's Manual; National Risk Management Research Laboratory: Cincinnati, OH, USA, 2015.

22. Martínez, C.; Sanchez, A.; Galindo, R.; Mulugeta, A.; Vojinovic, Z. and Galvis, A. Configuring Green Infrastructure for Urban Runoff and Pollutant Reduction Using an Optimal Number of Units. Water 2018, vol. 10 no. 11, pp.1528.

23. Gong, Y.; Yin, D.; Fang, X. and Li, J. Factors affecting runoff retention performance of extensive green roofs. Water 2018, vol. 10 no. 9, pp. 1217.

24. Mora-Melià, D.; López-Aburto, C. S.; Ballesteros-Pérez, P. and MuñozVelasco, P. Viability of green roofs as a flood mitigation element in the central region of Chile. Sustainability 2018, vol. 10 no. 4, pp. 1130.

25. Howard, C.D.D. Theory of Storage and Treatment-Plant Overflows. J. Environ. Eng. Div. 1976, vol. 102, pp. 709-722.

26. Di Toro, D.M. and Small, M.J. Stormwater Interception and Storage. J. Environ. Eng. Div. 1979, no. 105, pp. 43-54.

27. Loganathan, V.G.; Deniur, J.W.; Segarra, R.I. Planning Detention Storage for Stormwater Management. J. Water Resour. Plan. Manag. 1985, vol. 111, pp. 382-398.

28. Meredith, D.D.; Middleton, A.C. and Smith, J.R. Design of Detention Basins for Industrial Sites. J. Water Resour. Plan. Manag. 1990, vol. 116, pp. 586591.

29. Takamatsu, M. Hydraulic model for sedimentation in storm-water detention basins. J. Environ. 2009, vol. 136, pp. 527-534.

30. De Martino, G.; de Paola, F.; Fontana, N.; Marini, G. and Ranucci, A. Pollution Reduction in Receivers: Storm-Water Tanks. J. Urban Plan. Dev. 2011, vol. 137, pp. 29-38.

31. Butler, D. and Schütze, M. Integrating simulation models with a view to optimal control of urban wastewater systems. Environ. Model. Softw. 2005, vol. 20, pp. 415-426.

32. Fu, G.; Butler, D. and Khu, S.T. Multiple objective optimal control of integrated urban wastewater systems. Environ. Model. Softw. 2008, vol. 23, pp. 225-234.

33. Andrés-Doménech, I.; Montanari, A. and Marco, J.B. Efficiency of Storm Detention Tanks for Urban Drainage Systems under Climate Variability. $J$. Water Resour. Plan. Manag. 2012, vol. 138, pp. 36-46.

34. Wang, M.; Sun, Y. and Sweetapple, C. Optimization of storage tank locations in an urban stormwater drainage system using a two-stage approach. $J$. Environ. Manag. 2017, vol. 204, pp. 31-38. 
35. Cunha, M.C.; Zeferino, J.A.; Simões, N.E. and Saldarriaga, J.G. Optimal location and sizing of storage units in a drainage system. Environ. Model. Softw. 2016, no. 83, pp. 155-166.

36. Tao, T.; Wang, J.; Xin, K. and Li, S. Multi-objective optimal layout of distributed storm-water detention. Int. J. of Environ. Sci. and Tech. 2014, vol. 11 no. 5, pp. 1473-1480.

37. Li, F.; Duan, H. F.; Yan, H. and Tao, T. Multi-objective optimal design of detention tanks in the urban stormwater drainage system: framework development and case study. Water Resour. Manag. 2015, vol. 29, no. 7, pp. 2125-2137.

38. Reyna, S. M.; Vanegas, J. A. and Khan, A. H. Construction Technologies for Sewer Rehabilitation. J. Constr. Eng. Manag 1994, vol. 120, no. 3, pp. 467487.

39. Gaudio, R.; Penna, N. and Viteritti, V. A combined methodology for the hydraulic rehabilitation of urban drainage networks. Urban Water J. 2016, vol. 13, pp. 644-656.

40. Sebti, A.; Bennis, S. and Fuamba, M. Optimization of the restructuring cost of an urban drainage network. Urban Water J. 2016, vol. 13 no. 2, pp. 119-132.

41. Karamouz, M.; Hosseinpour, A. and Nazif, S. Improvement of urban drainage system performance under climate change impact: Case study. J. of Hydro Eng. 2010, vol. 16, no. 5, pp. 395-412.

42. Xu, K.; Bin, L.; Lian, J. and Liu, R. Staged optimization design for updating urban drainage systems in a City of China. Water 2018, vol. 10 no. 1, pp. 66.

43. Ouellet, M. and Duchesne, S. A method to consider replaced pipes in modeling of sewer pipe deterioration. Urban Water J. 2018, vol. 15, no. 4, pp. 392-397.

44. Barreto, W.; Vojinovic, Z.; Price, R. and Solomatine, D. Multiobjective evolutionary approach to rehabilitation of urban drainage systems. J. of water resour. plan. and manag. 2009, vol. 136 no. 5, pp. 547-554.

45. Vojinovic, Z.; Sahlu, S.; Torres, A. S.; Seyoum, S. D.; Anvarifar, F.; Matungulu, H. and Kapelan, Z. Multi-objective rehabilitation of urban drainage systems under uncertainties. J. Hydroinfo 2014, vol. 16 no. 5, pp. 1044-1061.

46. Lim, S.; Ho, V. H.; Lee, S. Y.; Yoo, D. G. and Kim, J. H. Determination of optimal location and capacity of detention facilities. Procedia Eng 2014, Vol. 70, pp. 1037-1045.

47. Beraud, B.; Mourad, M.; Soyeux, E.; Lemoine, C. and Lovera, M. Optimisation of sewer networks hydraulic behaviour during wet weather: coupling genetic algorithms with two sewer networks modelling tools. NOVATECH 2010.

48. Yazdi, J. Rehabilitation of Urban Drainage Systems Using a Resilience-Based Approach. Water Resour Manag 2018, vol. 32 no. 2, pp. 721-734.

49. Paredes Méndez, D. F.; Sanchez-Torres, A.; Vojinović, Z. and Seyoum, S. D. Multi-Objective-Rehabilitation Of Urban Drainage Systems Within The Flood Risk Framework. International Conference on Hydroinformatics 2014. CUNY Academic Works. 
50. Yazdi, J.; Lee, E. H. and Kim, J. H. Stochastic multiobjective optimization model for urban drainage network rehabilitation. J. of Water Resour. Plan. and Manag. 2014, vol. 141, no. 8, pp. 04014091.

51. Maier, H. R.; Kapelan, Z.; Kasprzyk, J.; Kollat, J.; Matott, L. S.; Cunha, M. C. and Ostfeld, A. Evolutionary algorithms and other metaheuristics in water resources: Current status, research challenges and future directions. Environ Model Softw 2014, vol. 62, pp. 271-299.

52. Sophocleous, S.; Savić, D. and Kapelan, Z. Leak Localization in a Real Water Distribution Network Based on Search-Space Reduction. J Water Resour Plan Manag 2019, vol. 145 no. 7, pp. 04019024.

53. Leitão, J.P.; Carbajal, J.P.; Rieckermann, J.; Simões, N.E.; Marques, A.S. and de Sousa, L.M. Identifying the best locations to install flow control devices in sewer networks to enable in-sewer storage. J. Hydrol. 2018, vol. 556, pp. 371383.

54. Wang Q.; Zhou, Q.; Lei, X. and Savić, D. A. Comparison of Multiobjective Optimization Methods Applied to Urban Drainage Adaptation Problems. $J$. Water Resour. Plan. Manag. 2018, vol. 144, no. 11, pp. 04018070.

55. Lee, E. and Kim, J. Development of Resilience Index Based on Flooding Damage in Urban Areas. Water 2017, vol. 9, pp. 428.

56. Iglesias-Rey, P.L.; Martínez-Solano, F.J.; Saldarriaga, J.G. and NavarroPlanas, V.R. Pseudo-genetic Model Optimization for Rehabilitation of Urban Storm-water Drainage Networks. Procedia Eng. 2017, vol. 186, pp. 617-625.

57. Mora-Melia, D.; Iglesias-Rey, P.L.; Martinez-Solano, F.J.; Fuertes-Miquel, V.S. Design of Water Distribution Networks using a Pseudo-Genetic Algorithm and Sensitivity of Genetic Operators. Water Resour. Manag. 2013, vol. 27, pp. 4149-4162

58. Raquel C. R. and Naval, P. C. An effective use of crowding distance in multiobjective particle swarm optimization. In Proceedings of the conference on Genetic and evolutionary computation - GECCO '05, 2005, pp. 257.

59. Mora Meliá, D.; Iglesias Rey, P.L.; Montalvo Arango, I.; Martínez Solano, F.J. Diseño de redes de saneamiento con algoritmos evolutivos. Comparación entre algoritmos genéticos y optimización PSO. VII SEREA - Seminario hispanobrasileño: Planificación, proyecto y operación de redes de abastecimiento de agua. Morelia, Mich. (México). 18 to 21 of June 2007. (In Spanish). 


\section{Appendices}




\section{Appendix I}

\section{Rehabilitación de redes de drenaje mediante la combinación de tanques de retención y sustitución de conducciones}

\section{Reference:}

Ngamalieu, U., Iglesias-Rey, P. L., Martinez-Solano, F. J., \& Saldarriaga, J. Rehabilitation of Drainage Networks through the Combination of Retention Tanks and Replacement of Pipelines. SSRN Electronic Journal 2017. http://doi.org/10.2139/ssrn.3113706 


\section{Resumen}

Las redes de drenaje de nuestras ciudades experimentan en la actualidad un creciente aumento de los caudales de escorrentía, originados principalmente por la impermeabilización del suelo y los efectos del cambio climático [1]. Esto origina que redes originalmente diseñadas de forma correcta presenten inundaciones con periodos de retorno muy inferiores a los considerados en la fase de diseño.

En este trabajo se presenta una metodología de rehabilitación de estas redes de drenaje basada en uso combinado de la instalación de tanques de retención y la sustitución de ciertas conducciones del sistema. Para ello se emplea un método de optimización basado en costes y en un algoritmo heurístico pseudo genético [2] cuya eficiencia [3] ha sido validada ya en otros campos. Asimismo, se emplea como el modelo SWMM de análisis hidráulico de redes de drenaje y saneamiento [4].

Este método de optimización se utiliza de forma recursiva para realizar una determinación de la pre-localización de los tanques de retención y de las tuberías potencialmente sustituibles. Posteriormente el método realiza un dimensionado detallado de los tanques y conductos a sustituir. La metodología ha sido aplicada sobre un sector de la red de drenaje de la ciudad de Bogotá, mostrando como la utilización conjunta de tanques y conductos conlleva a soluciones de rehabilitación de menor coste.

Palabras clave: Redes de drenaje, cambio climático, rehabilitación, optimización, SWMM

\section{I.1. Introducción}

Con el transcurso del tiempo las redes de alcantarillado presentan deficiencias respecto de los objetivos de funcionamiento con los que fueron diseñados en el momento de su construcción. Al igual que la mayoría de las construcciones de interés público, las redes de alcantarillado y drenaje de las ciudades tienen su propósito fundamental limitado. En el caso de las redes saneamiento este límite está en la capacidad de drenaje, que está limitada a ciertos eventos de lluvia obtenidos a partir del análisis histórico de precipitaciones. Las inundaciones en las áreas urbanas se han vuelto cada vez más comunes en las últimas décadas. Este aumento de las inundaciones es consecuencia del aumento de la urbanización, la disminución de las tasas de infiltración del terreno y el aumento de las precipitaciones originado por el cambio climático [5].

El cambio climático está claramente identificado como el causante del cambio del régimen de precipitaciones tanto en intensidad como en frecuencia. Las proyecciones reales proporcionadas por los modelos climáticos sugieren que la probabilidad de ocurrencia de lluvias intensas aumentará en un futuro debido al aumento de las 
condiciones de los gases de efecto invernadero [6]. Estas nuevas condiciones de lluvia derivadas del cambio climático hacen prever que las redes urbanas diseñadas para ciertas condiciones de lluvia no puedan funcionar de forma eficaz en el futuro [7].

La disminución del rendimiento de las redes de drenaje y alcantarillado no está provocada únicamente por el cambio climático y la impermeabilización del suelo. Otros efectos [5] como el envejecimiento de las infraestructuras, el colapso estructura de algunos conductos y la aparición de fugas genera una disminución de las prestaciones de este tipo de sistemas. En última instancia, los responsables de la gestión municipal de estas infraestructuras de drenaje son los que deben garantizar la eficacia de las redes a fin de aportar un servicio acorde a las demandas de sus usuarios y clientes.

Por ello, los servicios de drenaje y alcantarillado y los encargados de su gestión y operación deben contar con planes de rehabilitación que permitan garantizar el funcionamiento de las infraestructuras. Estos planes deben contemplar la respuesta del sistema ante procesos en los que las precipitaciones continúen siendo crecientes. Para ello, los gestores de estos sistemas disponen de diferentes alternativas: control en tiempo real (RTC) de la red, reparación de la red, renovación completa de partes del sistema o un sistema de rehabilitación integral de la red.

En la literatura existen diferentes trabajos sobre la rehabilitación de redes de alcantarillado y drenaje. Reyna et al. [8] presentan una síntesis sobre el estado del arte acerca de las tecnologías de construcción para la rehabilitación de redes de alcantarillado. Asimismo, presenta una planificación óptima de la rehabilitación de redes de drenaje que incluye en un programa marco de rehabilitación de infraestructuras. Abraham et al. [9] plantean por su parte una gestión integrada de los sistemas de drenaje, en la que incluyen aspectos tales como: la identificación y clasificación de los elementos de la red, los mecanismos de control del estado de la red, el desarrollo de un modelo predictivo de lluvias y el uso de técnicas de optimización que permitan maximizar el ratio beneficio coste en un cierto periodo horizonte definido. En la línea de la identificación del estado de la red Moselhi y Shehab-Eldeen [10] presentan un sistema automatizado para detectar fugas y defectos en las tuberías de las redes de saneamiento, centrándose fundamentalmente en la aplicación de las redes neuronales para la clasificación de estos defectos. Así, los defectos existentes en las redes se engloban en cuatro categorías principales: grietas, desplazamiento de las uniones, reducción de la sección transversal de paso y hundimiento parcial de los conductos.

El análisis hidráulico de redes de alcantarillado en situaciones de precipitaciones extremas es un proceso que requiere gran cantidad de cálculos al realizarse normalmente utilizando algoritmos que contemplen tanto la entrada en carga como la posibilidad de 
inundación. El objetivo de este trabajo consiste en proponer una metodología para la rehabilitación de redes de alcantarillado considerando tanto los costes de instalación como los costes asociados a los daños provocados por las inundaciones. Con el objetivo de reducir los tiempos de cálculo, se ha optado por una metodología que permite reducir el número de variables de decisión sin comprometer por ello la calidad de las soluciones. Para ello se combina un algoritmo pseudo-genético [11] conectado con el simulador hidráulico SWMM5 [12] mediante una librería de conexión (Toolkit, [13]). Esto permite un análisis rápido y eficaz del comportamiento de la red objeto de estudio. Esta metodología se ha contrastado aplicándola a la red de alcantarillado del distrito de Chicó en Bogotá (Colombia).

\section{I.2. Descripción del problema}

El problema que se pretende resolver pasa por ampliar las capacidades de la red para hacer frente a posibles incrementos en la intensidad de las precipitaciones como consecuencia de un eventual cambio climático. Por una parte, se plantea la utilización de soluciones tradicionales basadas en la rehabilitación de conductos y el aumento de su capacidad de trasporte. Por otra, se incluye la posibilidad de gestionar una cierta capacidad de almacenamiento en red a través de la instalación de tanques de tormenta de capacidad limitada a lo largo de la red, en aquellos puntos donde su presencia pueda contribuir a laminar los caudales máximos asociados a una precipitación importante. En este punto surgen diversas configuraciones del problema:

1. Sustitución de conductos sin modificación de su pendiente:

\subsection{Sin modificación de la zanja.}

Esta opción es posible si el nuevo conducto debe tener un diámetro inferior al original. Al trabajar con pendiente constante, solo el diámetro y eventualmente el coeficiente de fricción (p.ej. $\mathrm{n}$ de Manning) cambiarían. El coste sólo afecta a 1 nuevo conducto.

\subsection{Con modificación de la zanja.}

En el supuesto que el tubo a instalar fuese de mayor diámetro, o si se considera que para la sustitución es necesario abrir nuevamente la zanja, al coste del conducto habría que añadirle los costes asociados a la excavación y posterior reposición de la zanja.

2. Sustitución de conductos con modificación de su pendiente:

Para soluciones basadas en esta configuración, para cada conducto reemplazado cambian sus dimensiones, coeficiente de fricción, pendiente y cotas de los extremos. Así 
mismo, para esta configuración los costes asociados deben incluir tantos los costes de la tubería como los costes de excavación.

3. Instalación de tanques de retención sin control hidráulico:

Los nudos suelen representar pozos de registro y estos tienen una capacidad de almacenamiento muy limitada. Así, para eventos de lluvia importantes si el conducto situado aguas abajo no tiene capacidad de transporte, los nudos se llenan fácilmente y provocan inundaciones. Por ello, una de las soluciones que se plantean es la posibilidad de incrementar su capacidad de almacenamiento mediante tanques de retención. En estos casos, la superficie que ocupan pasar a ser la variable del problema. Los costes asociados a esta solución son la suma de los costes de excavación y los costes de los propios tanques.

4. Instalación de tanques de retención con control hidráulico:

El objetivo de utilizar tanques de retención es el de retener el exceso de agua de lluvia para posteriormente devolverlo a la propia red. La utilización del control hidráulico permite controlar la cantidad de agua retenida y la derivada, así como elegir el mejor momento para desaguar el agua almacenada. Esto permite determinar el diámetro del conducto situado aguas abajo del tanque cuya función consiste precisamente en actuar como elemento resistente regulador del caudal. En ocasiones, el elemento regulador puede ser una válvula, una compuerta, un vertedero, etc. Los costes asociados a esta solución incluyen, además de la excavación y el propio tanque, los asociados al elemento encargado de la regulación.

En el presente trabajo, la metodología utilizada consiste en combinar soluciones basadas en las configuraciones 1 y 3 , esto es, cambios de conductos sin alterar su pendiente (modificando solo diámetro y coeficiente de fricción) e instalación de tanques de retención sin control hidráulico. Dada la complejidad del problema y la multitud de soluciones posibles, se ha optado por un método heurístico. En este caso, se utilizará un algoritmo pseudo-genético [11] que permite optimizar una función objetivo en este caso expresada como costes que hay que minimizar.

Esta función objetivo se ha formulado de forma que se tengan en cuenta todos los costes asociados a la rehabilitación de una red de alcantarillado. Como la función objetivo presenta resultados monetarios, ha sido necesario definir una función de costes de penalización para los eventos de inundación. La función objetivo se expresa como:

$$
F . O=\lambda_{1} \sum_{i=1}^{N} C_{I}(i)+\lambda_{2} \sum_{i=1}^{N} C_{T}(i)+\lambda_{3} \sum_{i=1}^{N_{C}} C_{C}(i)+\lambda_{1} \sum_{i=1}^{N_{C}} C_{V}(i)
$$

En esta ecuación: 
(i) coste total de inundación generado en cada uno de los $N$ nudos,

(i) coste de instalación de cada uno de los NT tanques,

(i) coste de instalación de cada uno de los $N C$ conductos,

(i) coste de penalización por el exceso de volumen de agua en cada uno de los $N C$ conductos, si se opta por limitar la capacidad de estos.

Cada uno de estos términos lleva asociado un coeficiente de peso $\left(\lambda_{1}, \ldots, \lambda_{4}\right)$ cuya función es la de priorizar unos costes u otros.

\section{I.3. Metodología}

La metodología propuesta para el desarrollo de la rehabilitación de las redes de pluviales mediante el uso conjunto de tanques de retención y renovación de conducciones se basa en las siguientes fases o etapas:

a) Elaboración de un modelo matemático fiable de la red de alcantarillado para poder analizar el comportamiento de la misma. En dicho modelo se debe incluir la lluvia de proyecto seleccionada, así como un estudio hidrológico que permita transformar la lluvia en caudales de escorrentía.

b) Definir las potenciales variables de decisión del problema. Esto es, definir los potenciales puntos en los que podría instalarse un tanque de retención y definir los posibles conductos a ser rehabilitados y sustituidos por un conducto nuevo de dimensiones diferentes a las iniciales.

c) Definir las funciones de coste de cada uno de los elementos que forman parte de la función objetivo del proyecto (costes de inversión en conductos y tanques, costes de inundación, etc.).

d) Realizar una localización inicial de posibles ubicaciones de las estructuras de almacenamiento y de los conductos a rehabilitar. Esta operación tiene un carácter más cualitativo que cuantitativo y se busca ante todo la velocidad para alcanzar soluciones fiables.

e) Por último, tras fijar las posibles ubicaciones de los puntos donde se producirán las actuaciones sobre la red, se realiza una segunda optimización cuyo objetivo es dimensionar estas actuaciones. Dicha optimización ofrece como resultado final la solución de diseño de la red.

\section{I.4. Caso de estudio}

La metodología presentada se ha aplicado a un distrito de la red de alcantarillado de la ciudad de Bogotá (Colombia). Esta red, denominada genéricamente E-Chicó, se extiende sobre una superficie total de 51 ha y se ha dividido en 35 subcuencas hidrológicas. La longitud total de los conductos suma casi $5 \mathrm{~km}$ de tuberías circulares con diámetros en el rango entre 300 y $1400 \mathrm{~mm}$. El desnivel entre el punto más elevado y el más bajo es de 39,38 m. Toda la red drena exclusivamente por gravedad debido a que el terreno presenta pendientes naturales que favorecen el drenaje del agua de lluvia. 
Para el diagnóstico y posterior evaluación de las posibles soluciones se ha utilizado una lluvia de proyecto obtenida por bloques alternos a partir de las curvas IDF obtenidas por un equipo de la Universidad de Los Andes (Bogotá, Colombia) teniendo en cuenta diversos escenarios de cambio climático [4]. Los resultados obtenidos en esta primera simulación muestran un volumen total de inundación de $3835 \mathrm{~m} 3$, lo cual supone un $16 \%$ del total del volumen de escorrentía generado $(23690 \mathrm{~m} 3)$. Además, más del $70 \%$ de los nudos muestran niveles de inundación en mayor o menor medida ( 25 de los 35 nudos). La Figura 1 muestra un esquema de la red, así como los resultados de inundación en nudos y capacidad de los conductos.

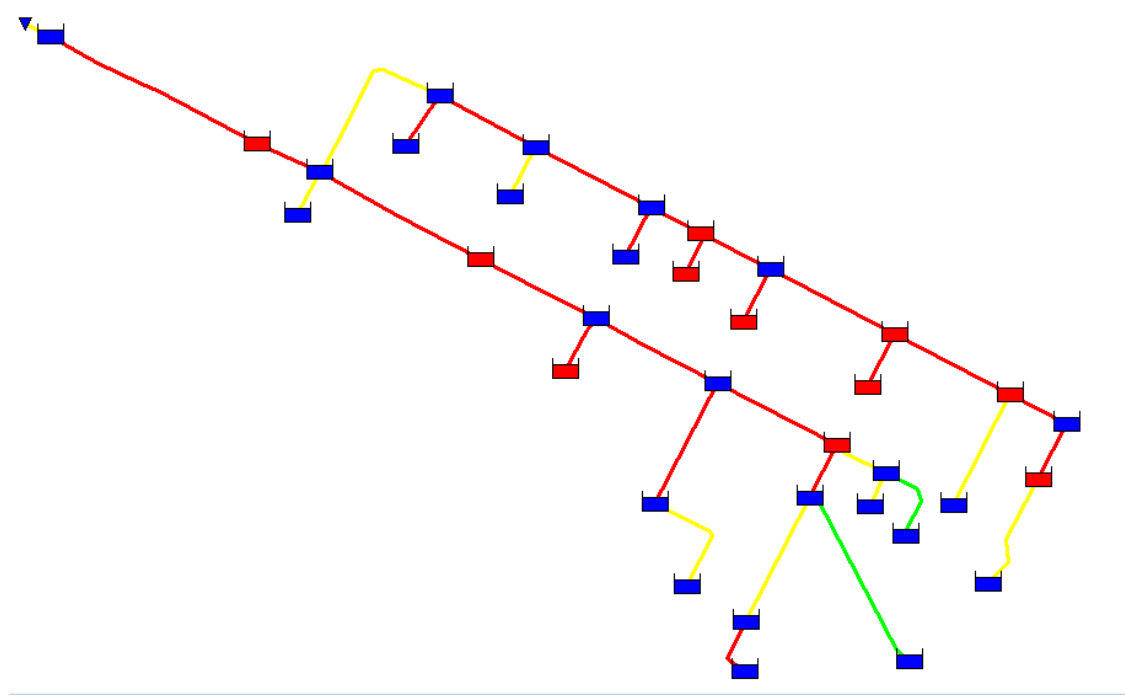

Figura 1. Esquema de la red de E-Chicó y resultados obtenidos antes de acometer ninguna acción.

En definitiva, el análisis preliminar de la red muestra que la misma es insuficiente para drenar la lluvia de proyecto seleccionada. Por ello, la red E-Chicó se consideró adecuada para aplicar los algoritmos de optimización desarrollados. En primer lugar, se optó por buscar las ubicaciones de los tanques de almacenamiento y conductos a modificar directamente utilizando un algoritmo genético modificado para permitir el trabajo con variables continuas [11]. Para ello, se utilizaron 3 escenarios:

- Escenario 1. Rehabilitación de la red en base únicamente a modificar los conductos de la red y sustituirlos por unos de diámetro diferente. Este escenario tiene 35 variables de decisión: las 35 conducciones cuyos diámetros se dejan como incógnitas. 
- Escenario 2. Rehabilitación de la red instalando únicamente tanques de retención. Este escenario también tiene 35 variables de decisión, correspondiente a los 35 potenciales nudos en los que se puede instalar tanques de retención.

- Escenario 3. Rehabilitación de la red combinando la instalación de conducciones y tanques de retención. El número de variables de decisión es 70 .

Una de las principales conclusiones obtenidas de este primer análisis es el tiempo necesario para completar las simulaciones debido al elevado número de variables de decisión y a lo amplio del espacio de soluciones. Además, después de realizar numerosas simulaciones, se observó igualmente una gran dispersión en los resultados. Adicionalmente, se pudo concluir que la combinación de cambio de diámetros e instalación de tanques daba mejores resultados que la optimización de cualquiera de ellos por separado.

La metodología que se presenta se ha sometido a un proceso de mejora con el fin de obtener resultados óptimos sin necesidad de modificar significativamente los parámetros propios del algoritmo genético utilizado para realizar las simulaciones. Puesto que estos parámetros se estiman en base al número de variables de decisión y la complejidad del problema, el objetivo se centra ahora en reducir el número de nudos y líneas susceptibles de ser modificados. Para conseguirlo, se ha evaluado y calibrado el modelo de la red de forma que la expresión empleada para evaluar los costes asociados a la inundación sea conforme a la expresión utilizada por el optimizador. A partir de ahí se ha desarrollado una metodología para reducir el número de variables de decisión.

\section{I.4.1. Pre-localización de los tanques de retención}

Para la pre-localización de los tanques de retención se han realizado 100 simulaciones con el algoritmo genético manteniendo todos los nudos como posibles ubicaciones de dichos tanques. El dimensionamiento de los tanques se basa en la superficie destinada a almacenamiento, viniendo el volumen dado por ésta y la profundidad máxima del nudo. En estas simulaciones, se parte de una superficie máxima destinada a almacenamiento y se trabaja con 10 divisiones. Como resultado de estas 100 simulaciones se realiza un análisis de resultados de forma que se han seleccionado las 10 mejores soluciones y, de éstas, se han seleccionado los puntos donde aparecen tanques de tormenta con mayor frecuencia.

De forma similar, se han realizado otras 100 simulaciones manteniendo todos los nudos como posibles ubicaciones, pero esta vez con 40 divisiones en lugar de 10 . De nuevo se han seleccionado las 10 mejores soluciones y, de éstas, se han seleccionado los puntos donde aparecen tanques de tormenta con mayor frecuencia.

Se ha realizado un conjunto de posibles ubicaciones de los tanques de la unión de estas dos evaluaciones (con 10 y con 40 simulaciones). De esta forma, el número de nudos susceptibles de albergar tanques de retención se ha reducido de 35 a 15. 


\section{I.4.2. Selección de conductos a modificar}

Para la selección de los conductos a modificar se ha procedido de manera similar. En primer lugar, se han realizado 100 simulaciones en las que todos los conductos son susceptibles de ser reemplazados. De estas simulaciones, de nuevo se han seleccionado las 100 mejores y se han seleccionado los conductos que han precisado de alguna modificación.

En determinadas circunstancias en las que bien la red dispone de conductos de pequeño tamaño, bien la lluvia de proyecto elegida es mayor o corresponde a periodos de retorno mayores, se ha observado que la gran mayoría de los conductos precisan de alguna modificación. Obviamente, en estas situaciones es difícil reducir el tamaño del problema. Por ello, en estos casos estas simulaciones se realizan con la combinación de cambios de sección en los conductos y almacenamiento en los nudos. Dado que cuando se procesa la combinación de ambas alternativas los resultados obtenidos son mejores, se utilizan estas simulaciones para preseleccionar los conductos candidatos a su rehabilitación. En este trabajo se han realizado ambas alternativas obteniendo dos escenarios adicionales a los tres presentados anteriormente:

- Escenario 4. Rehabilitación de la red combinando la posibilidad de instalar tanques de retención en los 15 puntos antes señalados y los conductos que aparecen modificados en las 10 mejores soluciones de las simulaciones realizadas sólo con conductos. Esto supone seleccionar 15 posibles conductos a reemplazar.

- Escenario 5. Rehabilitación de la red combinando la posibilidad de instalar tanques de retención en los 15 puntos antes señalados y los conductos que aparecen modificados en las 5 mejores soluciones de las simulaciones realizadas sólo con conductos. En este caso, solo 8 conductos son candidatos a ser sustituidos.

\section{I.4.3. Análisis de resultados}

Los resultados obtenidos para los 5 escenarios procesados se pueden observar en la Tabla 1. En dicha tabla se puede observar claramente que cuando la rehabilitación de conductos se combina con la instalación de tanques de retención el valor de la función objetivo obtenida es mejor. Esto se deduce de la comparación de los escenarios 1 (sólo conductos), 2 (sólo tanques) y 3 (combinación de ambas alternativas). Adicionalmente, la aplicación de la metodología propuesta basada en la reducción del número de variables de decisión consigue mejorar aún más dichos resultados. Así, a pesar de disponer de menos variables de decisión, los escenarios 4 y 5 dan mejores resultados que los 3 escenarios precedentes, validando la metodología. Finalmente, la Figura 2 recoge los resultados obtenidos para la solución obtenida en el escenario 5. 
Tabla 1. Resumen de resultados.

\begin{tabular}{|c|c|c|c|c|c|c|c|}
\hline Scenario & $\begin{array}{c}\text { Decision variables } \\
\text { Number }\end{array}$ & $\begin{array}{l}\text { Objective } \\
\text { Function }\end{array}$ & $\begin{array}{c}\text { Floods } \\
\text { costs }\end{array}$ & $\begin{array}{c}\text { Storage tanks } \\
\text { Costs }\end{array}$ & $\begin{array}{c}\text { Conductuits } \\
\text { Costs }\end{array}$ & $\begin{array}{c}\text { Number of installed } \\
\text { storage tanks }\end{array}$ & $\begin{array}{c}\text { Number of } \\
\text { substituted conduits }\end{array}$ \\
\hline 1 & 35 & 763164 & 7622 & 0 & 755542 & 0 & 6 \\
\hline 2 & 35 & 273459 & 5392 & 268067 & 0 & 16 & 0 \\
\hline 3 & 70 & 254046 & 8363 & 237457 & 8226 & 4 & 3 \\
\hline 4 & 30 & 245547 & 8352 & 213133 & 24061 & 4 & 5 \\
\hline 5 & 23 & 218501 & 12701 & 186353 & 19448 & 3 & 3 \\
\hline
\end{tabular}

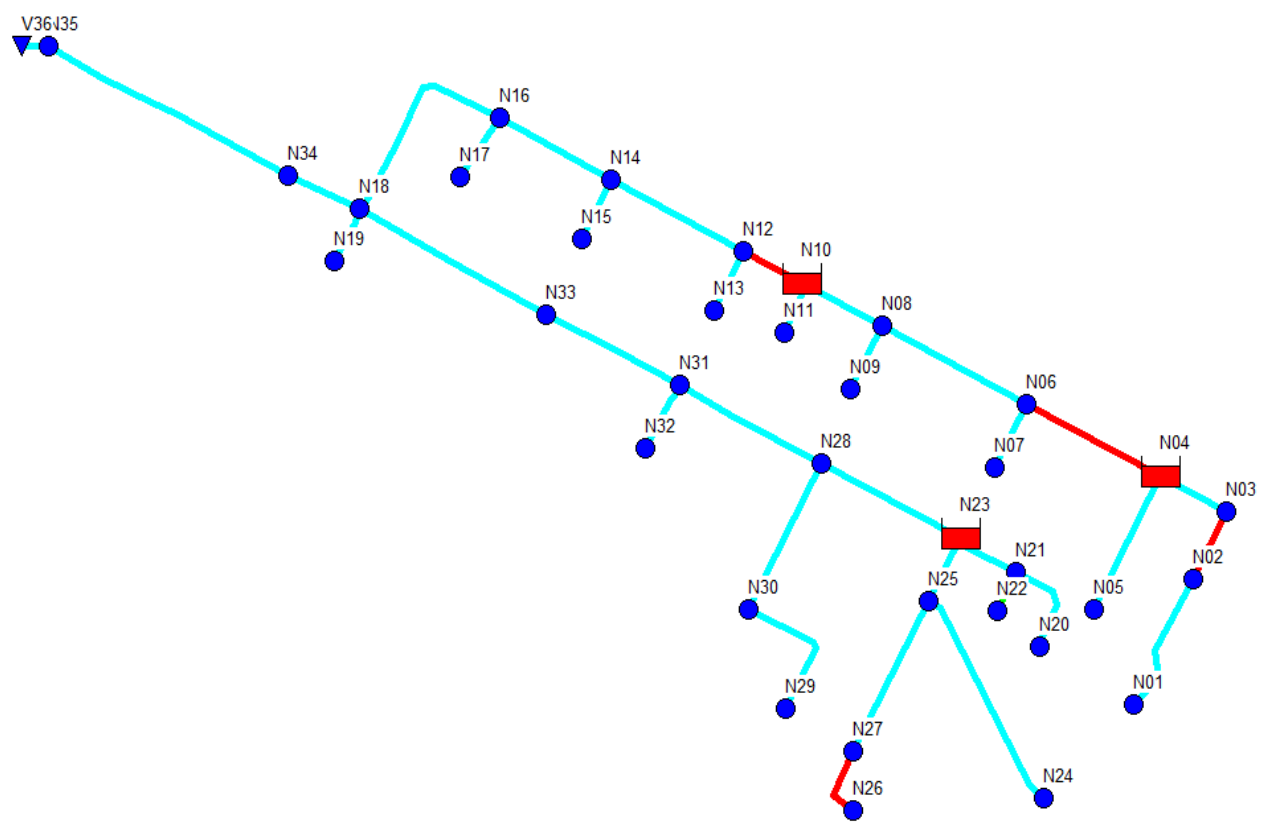

Figura 2. Representación de los nudos de inundación y de la capacidad de los conductos durante el evento de lluvia. Escenario 5.

\section{I.5. Conclusiones}

De los resultados obtenidos en el estudio presentado es posible extraer las siguientes conclusiones:

- Se ha presentado un método para reducir el tamaño del problema de rehabilitación de redes de alcantarillado mediante la pre-localización de las ubicaciones donde se han de acometer actuaciones. En este caso las actuaciones consistían en la instalación de tanques de retención y rehabilitación de conductos. 
- El número de variables de decisión se ha reducido considerablemente con respecto al número de variables de decisión iniciales.

- De igual forma, los tiempos de simulación también se han reducido con respecto a los medidos para los escenarios en los que no ha habido pre-localización de las actuaciones.

- A pesar de la limitación en el espacio de soluciones, los resultados obtenidos en los escenarios con reducción del tamaño del problema son mejores que los obtenidos al resolver el problema completo.

- Los resultados obtenidos para la función objetivos son mínimos que no eliminan la posibilidad de inundación. Esto se debe al uso de una función de costes para los daños provocados por ésta, lo que la convierte en un parámetro más del problema y no en una restricción. Las inundaciones recogidas en las soluciones obtenidas son en la mayoría de los casos muy pequeñas en comparación con la situación inicial.

Como conclusión final podemos afirmar que los resultados obtenidos con esta metodología son aceptables a pesar del hecho de que los algoritmos heurísticos no garantizan que se alcance el mínimo absoluto de la función objetivo. A esta limitación hay que añadir que se ha trabajado con un número reducido de variables de decisión. La parte más difícil del método propuesto es la que se deriva de la selección de las variables de decisión realmente importantes.

\section{I.6. Agradecimientos}

Los autores desean agradecer a la empresa PAVCO-MEXICHEM de Colombia y al Departamento Administrativo de Ciencia, Tecnología e Innovación COLCIENCIAS, de la República de Colombia, por la financiación de la investigación "Drenaje Urbano y Cambio Climático: Hacia los Sistemas de Drenaje Urbano del Futuro" dentro de la cual se desarrolló el trabajo objeto de este artículo.

\section{I.7. Referencias}

1. L. A. Rossman, Storm Water Management Model User's Manual Version 5.1, no. September. Cincinnati, OH 45268: Environmental Protection Agency, 2015.

2. D. Mora-Melia, P. L. Iglesias-Rey, F. J. Martinez-Solano, and V. S. Fuertes-Miquel, "Design of Water Distribution Networks using a Pseudo-Genetic Algorithm and Sensitivity of Genetic Operators," Water Resour. Manag., vol. 27, no. 12, pp. 41494162, Jul. 2013.

3. D. Mora-Melia, P. L. Iglesias-Rey, F. J. Martinez-Solano, and P. Ballesteros-Pérez, "Efficiency of Evolutionary Algorithms in Water Network Pipe Sizing," Water Resour. Manag., vol. 29, no. 13, 2015.

4. J. Saldarriaga, I. Camilloni, M. Cunha, P. Iglesias, F. J. Martínez, and D. Páez, 
“DRENAJE URBANO Y CAMBIO CLIMÁTICO: HACÍA LOS SISTEMAS DE ALCANTARILLADO DEL FUTURO," in XIII Simposio Iberoamericano de Redes de Agua, Esgoto e Drenagem (SEREA 2014), 2014.

5. J. Yazdi, A. Sadollah, E. H. Lee, D. G. Yoo, and J. H. Kim, "Application of multiobjective evolutionary algorithms for the rehabilitation of storm sewer pipe networks," J. Flood Risk Manag., 2015.

6. A. Mailhot and S. Duchesne, "Design Criteria of Urban Drainage Infrastructures under Climate Change," J. Water Resour. Plan. Manag., vol. 136, no. 2, pp. 201208, Mar. 2010.

7. P. Kirshen, L. Caputo, R. M. Vogel, P. Mathisen, A. Rosner, and T. Renaud, "Adapting Urban Infrastructure to Climate Change: A Drainage Case Study," J. Water Resour. Plan. Manag., vol. 141, no. 4, p. 4014064, Apr. 2015.

8. S. M. Reyna, J. A. Vanegas, and A. H. Khan, "Construction Technologies for Sewer Rehabilitation,” J. Constr. Eng. Manag., vol. 120, no. 3, pp. 467-487, Sep. 1994.

9. D. Gilbert, E. Abraham, I. Montalvo, and O. Piller, "Iterative Multistage Method for a Large Water Network Sectorization into DMAs under Multiple Design Objectives," J. Water Resour. Plan. Manag., vol. 143, no. 11, p. 4017067, Nov. 2017.

10. O. Moselhi and T. Shehab-Eldeen, "Classification of Defects in Sewer Pipes Using Neural Networks,” J. Infrastruct. Syst., vol. 6, no. 3, pp. 97-104, Sep. 2000.

11. D. Mora-Melia, P. L. Iglesias-Rey, F. J. Martinez-Solano, and V. S. Fuertes-Miquel, "Design of Water Distribution Networks using a Pseudo-Genetic Algorithm and Sensitivity of Genetic Operators," Water Resour. Manag., vol. 27, no. 12, pp. 41494162, 2013.

12. L. A. Rossman, "Storm Water Management Model User's Manual," Cincinnaty, $\mathrm{OH}, 2015$.

13. F. J. Martínez-Solano, P. L. Iglesias-Rey, J. G. Saldarriaga, and D. Vallejo, "Creation of an SWMM Toolkit for Its Application in Urban Drainage Networks Optimization," Water, vol. 8, no. 6, pp. 1-16, 2016. 


\section{Appendix II}

\section{Desarrollo de una metodología para proyectos de rehabilitación de redes de drenaje pluvial bajo escenarios de cambio climático}

\section{Reference:}

Ngamalieu-Nengoue, Ulrich Aurèle; Iglesias-Rey, Pedro L.; Martinez-Solano, F. Javier; Saldarriaga-Valderrama, Juan G.; Mora-Melia, Daniel. Development of a Methodology for Drainage Networks Rehabilitation Projects under Climate Change Scenarios. 22nd International Congress on Project Management and Engineering Madrid, 11th - 13th July 2018. PP. 659 - 671. ISBN: 978-84-09-05132-8. 


\section{Resumen}

Las redes de drenaje experimentan en la actualidad un creciente aumento de los caudales de escorrentía, originados principalmente por la impermeabilización del suelo y los efectos del cambio climático. Esto origina que redes originalmente diseñadas correctamente presenten inundaciones con periodos de retorno muy inferiores a los considerados en la fase de diseño.

En este trabajo se presenta una metodología de rehabilitación de estas redes de drenaje basada en tres etapas: un estudio de la lluvia de diseño obtenida a partir de modelos de cambio climático; un modelo de análisis hidráulico de la red y un modelo heurístico de optimización.

El modelo de optimización utilizado recursivamente permite la pre-localización de los tanques de retención y de las tuberías que potencialmente deberían ser rehabilitadas. Posteriormente el mismo método de optimización se emplea para el diseño de detalle de tanques y conductos.

La metodología desarrollada ha sido aplicada a un sector de la red de drenaje de Bogotá (Colombia). Los resultados muestran la fase de pre-localización reduce el espacio de búsqueda y aumenta la convergencia hacia la solución final. Asimismo, el método muestra como utilización conjunta de tanques y conductos supone proyectos de menor coste de inversión.

Palabras clave: Cambio climático; Optimización; rehabilitación; drenaje urbano

\section{II.1. Introduction}

Desde siempre, la humanidad ha tenido presente la importancia de evacuar las aguas tanto pluviales como residuales de sus asentamientos. Para ello, se construían redes de evacuación cuya misión principal era llevar las aguas precipitadas o servidas hasta puntos de vertido donde no constituyeran riesgos ni contra las personas ni contra las construcciones. Sin embargo, debido a las condiciones cambiantes tanto de la población como del clima, estas estas redes de alcantarillado presentan deficiencias respecto de los objetivos de funcionamiento con los que fueron diseñados en el momento de su construcción.

Como sucede con cualquier otra infraestructura, las redes de alcantarillado urbano se diseñan con un propósito y unos criterios definidos en un determinado momento. En el caso de las redes saneamiento, los criterios empleados se derivan de la capacidad de transporte de las conducciones y su relación con una serie de eventos de lluvia obtenidos a partir del análisis histórico de precipitaciones [1].

El efecto combinado del aumento de la urbanización, la impermeabilización del terreno y el aumento de las precipitaciones por causas antropogénicas (cambio climático y efecto de isla de calor) han hecho que las inundaciones en las áreas urbanas sean cada vez más frecuentes en los últimos tiempos [2]. 
La preocupación por el cambio climático está plenamente justificada. De la misma forma, es evidente la relación existente entre el cambio climático y el cambio del régimen de precipitaciones tanto en intensidad como en frecuencia en algunas zonas del planeta. Según algunos modelos climático, la probabilidad de ocurrencia de lluvias intensas aumentará en un futuro debido al aumento de las condiciones de los gases de efecto invernadero [3]. Resulta evidente que si cambian las condiciones de lluvia con respecto a las utilizadas en su día para el diseño de las redes de evacuación, éstas no podrán funcionar de manera eficaz en el futuro [4].

En cualquier caso, culpar de la falta de capacidad de las redes de alcantarillado exclusivamente al cambio climático o a la impermeabilización del suelo no sería del todo correcto. Existen otros aspectos como el envejecimiento de las infraestructuras, la falta de mantenimiento y el consecuente deterioro de algunos conductos que también generan una disminución en la capacidad de transporte los sistemas de drenaje. Es aquí donde surge la necesidad de un adecuado programa de rehabilitación y adaptación de las redes de alcantarillado a las condiciones cambiantes tanto climatológicas como hidrológicas. El enfoque tradicional por el cual la rehabilitación pasa necesariamente por el incremento en la capacidad de transporte de las conducciones puede resultar poco acertado e incluso antieconómico. Este enfoque se debe combinar con enfoques más novedosos como la utilización del control en tiempo real (RTC), la utilización de sistemas de drenaje urbano sostenible (SUDS) o el empleo de depósitos de retención.

Entre los diferentes trabajos que se han publicado en referencia con la rehabilitación de redes de alcantarillado destacan los presentados por Reyna et al. [5] sobre las tecnologías de construcción para la rehabilitación de redes de alcantarillado. Por su parte, Abraham et al. [6] plantean como estrategia de rehabilitación la gestión integrada de los sistemas de drenaje. Estos autores incluyen en su concepto de gestión integrada aspectos tales como la identificación y clasificación de los elementos de la red, los mecanismos de control del estado de la red, el desarrollo de un modelo predictivo de lluvias y el uso de técnicas de optimización que permiten priorizar unas estrategias de rehabilitación frente a otras, buscando la maximización del beneficio y la minimización del coste.

En este sentido, se presenta una metodología para optimizar las inversiones destinadas a la rehabilitación de redes de alcantarillado, pensando en escenarios derivados de las predicciones asociadas al cambio climático. El objetivo de este trabajo consiste en proponer una metodología para la rehabilitación de redes de alcantarillado considerando tanto los costes de instalación como los costes asociados a los daños provocados por las inundaciones. El análisis hidráulico de las redes de alcantarillado deberá incluir condiciones de lluvias extremas. Por ello, se han de utilizar modelos de cálculo hidráulico que incluyan situaciones derivadas de tales precipitaciones, como pueden ser la entrada en carga o la posibilidad de inundación. Estos modelos requieren en muchas ocasiones un análisis en periodo extendido con intervalos de cálculo muy pequeños, lo cual alarga las simulaciones. Por ello, con el objetivo de reducir los tiempos 
de cálculo, se ha optado por una metodología que permite reducir el número de variables de decisión sin comprometer por ello la calidad de las soluciones. Para ello se combina un algoritmo genético basado en una codificación entera Mora-Melia et al. [7] conectado con el simulador hidráulico SWMM5 (Rossman [8]) mediante una librería de conexión desarrollada para agilizar el acceso a los distintos elementos de la red (Martínez-Solano et al. [9]). Esto permite un análisis rápido y eficaz del comportamiento de la red objeto de estudio.

Finalmente, esta metodología se ha contrastado aplicándola a la red de alcantarillado del distrito de Chicó en Bogotá (Colombia).

\section{II.2. Objetivos}

\section{II.2.1. Formulación del problema}

Cuando una red de alcantarillado presenta problemas de inundación, las causas pueden ser diversas. Por una parte, la propia precipitación tiene un carácter casi aleatorio debido al elevado número de parámetros de los que depende. Esto se traduce en diseños que no pueden garantizar al $100 \%$ su funcionamiento sin riesgos. Así, las causas de la inundación pueden ser:

- La lluvia resulta objetivamente excesiva. Para compensar este problema, los protocolos de diseño deben incluir el concepto de riesgo en el diseño. Normalmente, en el campo de las redes de alcantarillado esto se trata a través de la selección del periodo de retorno. A mayor periodo de retorno menor riesgo de inundación y viceversa. Por ello, una de las fases del proyecto de rehabilitación ha de ser la selección de un periodo de retorno o, en su defecto, un nivel de riesgo asumible.

- La propia red de alcantarillado tiene una cierta capacidad de transporte. Sin ánimo de entrar en detalles hidráulicos, en régimen permanente hay una relación entre las condiciones internas de los conductos, su tamaño y el caudal que son capaces de transportar. Esta relación viene dada por la ecuación de Manning.

- Por último, se puede valorar la posibilidad de almacenar temporalmente el exceso de agua procedente de la lluvia con el fin de facilitar su posterior tratamiento y no trasladar el problema hacia aguas abajo, a puntos donde la cota pueda ser inferior y, por lo tanto, los problemas asociados a una posible inundación resulten más graves. Para ello, (Sánchez-Beltrán et al. [10]).

Con estos antecedentes, el problema se puede plantear como un problema de optimización en el que se busca minimizar los problemas asociados a las inundaciones con el mínimo coste de inversión, tanto en conducciones como en depósitos de retención. Esto conduce a una función objetivo compuesta a su vez de tres términos o funciones de coste y sujeta a una serie de restricciones. 
Las restricciones son principalmente las asociadas a las relaciones hidráulicas dentro de la propia red. Para ello, se hace necesario disponer de un modelo matemático de la misma que debe cumplir varios requisitos:

- Al tratarse de una rehabilitación para un horizonte futuro, deben incluirse escenarios que tengan en cuenta la posible variación de las condiciones de lluvia en eventos de cambio climático. Así, Gulizia y Camilloni [11] proponen el empleo de Modelos Globales de Cambio Climático para la obtención de tormentas de proyecto que tengan en cuenta estos escenarios.

- Dentro del ciclo hidrológico, el agua de lluvia sufre una serie de transformaciones desde que cae hasta que ingresa en la red de alcantarillado. Esto obliga a incorporar modelos de transformación de la lluvia en escorrentía. En este caso se empleará el modelo de depósitos no lineales incluido en el programa SWMM (Rossman y Huber [12]).

- A diferencia de otros planteamientos similares [13,14,15], que emplean aportes constantes y directos a la red de alcantarillado, en este proyecto se ha buscado estudiar la variación de la precipitación a lo largo del tiempo. Por ello, se ha resuelto el problema completo utilizando el modelo de resolución de la Onda Dinámica incluido en el mencionado SWMM.

\section{II.2.2. Funciones de coste}

El objetivo de la rehabilitación debe ser el de minimizar los problemas asociados a las inundaciones con el mínimo coste de inversión. Por lo tanto, además de las restricciones anteriores, de carácter principalmente hidráulico, es necesario definir una serie de funciones de coste. Para ello se utilizarán las presentadas por Navarro-Planas et al. [16] y que se reproducen brevemente a continuación:

1. Coste asociado a los daños provocados por las inundaciones en función del nivel alcanzado por las mismas (y). Este coste se ha determinado a partir de estudios realizados en la ciudad de Bogotá (Colombia) y relaciona el nivel alcanzado por el agua durante la inundación y el daño asociado a la misma $\left(C_{I}\right)$. A partir de un cierto nivel $\left(y_{\max }\right)$ el daño se considera irreparable y por tanto, la función deja de crecer y el coste alcanzará su máximo valor $\left(C_{\max }\right)$ :

$$
F_{1}=\sum_{i=1}^{N_{N}} C_{I}\left(y_{i}\right)=\sum_{i=1}^{N_{N}} C_{\max } \cdot\left(1-e^{-k \frac{y_{i}}{y_{\max }}}\right)
$$

2. Coste de inversión asociado al volumen de almacenamiento de los tanques $\left(C_{T}\right)$ que eventualmente fuese necesario instalar para absorber el exceso de agua que no es posible evacuar a través de la red de alcantarillado. Esta función tiene un término 
fijo $\left(C_{\min }\right)$ que recoge los costes fijos mínimos asociados a la obra y un término variable que depende del volumen total construido $(\mathrm{V})$ :

$$
F_{2}=\sum_{j=1}^{N_{T}} C_{T}\left(V_{D R, j}\right)=\sum_{j=1}^{N_{T}}\left(C_{\text {min }}+C_{v a r} \cdot V_{j}^{n}\right)
$$

3. Coste de rehabilitación de aquellas conducciones que bien por estar en malas condiciones interiores, bien por tener una capacidad de transporte insuficiente, fuese necesario reemplazar. En este caso, a partir de datos reales procedentes de fabricantes se ha ajustado la función que relaciona el coste unitario de las conducciones con su diámetro:

$$
F_{3}=\sum_{k=1}^{N_{C}} C_{C}\left(D_{N, k}\right) \cdot L_{k}=\sum_{k=1}^{N_{C}} L_{k} \cdot\left(A \cdot D_{k}+B \cdot D_{k}^{2}\right)
$$

\section{II.2.3. Función objetivo}

El objetivo de la rehabilitación debe ser el de minimizar los problemas asociados a las inundaciones con el mínimo coste de inversión. Por lo tanto, esta función objetivo estará compuesta a su vez de tres términos o funciones de coste:

La función objetivo debe minimizar los tres términos y para ello Navarro-Planas et al. [16] proponen plantear dicha función objetivo mediante multiplicadores de Lagrange:

$$
F . O=\lambda_{1} \sum_{i=1}^{N_{N}} C_{I}\left(y_{i}\right)+\lambda_{2} \sum_{j=1}^{N_{T}} C_{T}\left(V_{D R, j}\right)+\lambda_{3} \sum_{k=1}^{N_{C}} C_{C}\left(D_{N, k}\right) \cdot L_{k}
$$

En la función objetivo, cada uno de los términos definidos va precedido de un multiplicador de Lagrange $\left(\lambda_{1}, \lambda_{2}\right.$ y $\left.\lambda_{3}\right)$. Estos multiplicadores permiten decidir qué sumandos de la función objetivo se considerarán en cada proyecto de rehabilitación. Además, permite asignar importancias relativas a cada término. Ha de tenerse en cuenta que se están sumando términos que se han de ejecutar (los costes de inversión asociados a la rehabilitación de conducciones e instalación de depósitos de retención, CC y CT) con otros que incluyen el concepto de riesgo y probabilidad de ocurrencia, como es el caso de las inundaciones.

\section{II.2.4. Análisis del espacio de soluciones}

Los objetivos antes descritos se aplicarán a una versión simplificada del modelo de la red de alcantarillado del distrito de Chicó en Bogotá (Colombia). Este modelo 
simplificado, mostrado en la Figura 1, se compone de 35 conducciones y otros tantos nudos de conexión.

El problema de rehabilitación planteado inicialmente incluye la opción de rehabilitar cualquiera de las 35 conducciones y de instalar depósitos de retención en cualquiera de los 35 nudos. Disponemos por tanto de un total de 70 variables de decisión. A esto hay que añadirle la variabilidad de las mismas. En el caso de las conducciones, se dispone de 24 diámetros comerciales distintos, variando desde un mínimo desde 300 hasta $3000 \mathrm{~mm}$. Además, se ha incluido la posibilidad de no modificar el diámetro, lógico por otra parte si se trata de un problema de rehabilitación. Esto nos deja un total de 25 alternativas para cada uno de las 35 conducciones. Por su parte, la instalación de los depósitos de retención pasa por definir su volumen. El planteamiento realizado se ha basado en la definición que hace el programa SWMM del almacenamiento en estos elementos.

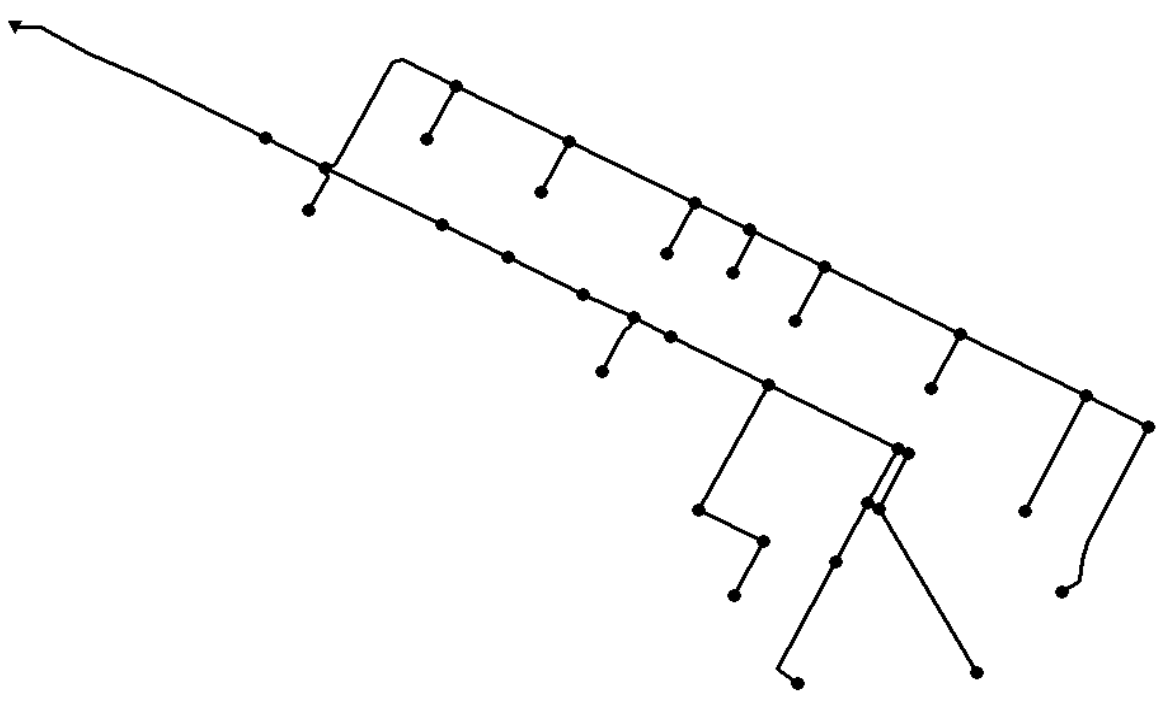

Figura 1: Esquema de la red de Chicó (Bogotá, Colombia) utilizada como caso de estudio.

Para SWMM, el volumen de almacenamiento se calcula a través del nivel alcanzado por el agua (z) y la sección del propio depósito. Esta sección (S) se puede hacer variar en función del nivel:

$$
S=A * Z^{B}+C
$$

Los coeficientes A, B y C son parámetros de ajuste de la curva de almacenamiento. De cara a la obtención de alternativas, se decidió trabajar solo con el coeficiente A. Además, los algoritmos utilizados en distintas fases del proyecto fueron 
de tipo heurístico (algoritmos genéticos, evolución diferencial y algoritmo genético multiobjetivo). Esto obliga a discretizar las soluciones. Por ello, se utilizó un área máxima, función de la superficie disponible con mínima afectación urbana y se dividió en particiones. Como primera aproximación se tomaron 40 particiones. Esta división, junto con las alternativas previstas para el caso de las conducciones nos deja un problema cuyo espacio de soluciones (esto es, el número de posibles soluciones que se pueden alcanzar) es de:

$$
E S=N_{C}^{N D} \cdot N_{T}^{N p}=35^{25} \cdot 35^{40}=2,3 \cdot 10^{100}
$$

Con tal cantidad de soluciones posibles, la probabilidad de alcanzar soluciones viables es escasa. Además, se desea que estas soluciones, además de viables, presenten costes bajos o, lo que es lo mismo, valores mínimos de la función objetivo. Todas estas circunstancias obligan a reducir de alguna forma el tamaño del problema. Dentro de la metodología que se expone a continuación se proponen algunas modificaciones al planteamiento del mismo que reducen el tamaño y consiguen mejoras en los resultados obtenidos.

\section{II.3. Metodología}

Para resolver el problema asociado a minimizar la función objetivo presentada en la ecuación (4) se ha optado por un algoritmo pseudo-genético (PGA), el cual cambia la codificación binaria tradicional por una codificación entera (Mora-Melia et al.[7]). La familia de los algoritmos evolutivos entre los cuales se incluyen los genéticos se basan en la evaluación de una cierta población de individuos los cuales representan distintas soluciones al problema. Al igual que sucede con las leyes de la selección natural descritas por Charles Darwin, de entre todos los individuos, aquellos mejor preparados (los que tienen mejores valores de la función objetivo) tendrán mayores probabilidades de supervivencia y de reproducción. Son por tanto algoritmos basados en el concepto de población y de generaciones. Esto hace que requieren de una intensidad de cálculo importante $\mathrm{y}$, consecuentemente, precisan de grandes tiempos de simulación. Obviamente, cuanto mayor es la población, mayores será las probabilidades de encontrar buenas soluciones [17].

La metodología propuesta para la resolución del problema de rehabilitación de redes de alcantarillado se basa en las siguientes fases o etapas:

1. Elaboración de un modelo matemático fiable de la red de alcantarillado. Este modelo ha de servir para comprobar el efecto de las acciones realizadas sobre el funcionamiento de la red y para ello se partirá de un modelo realizado sobre la base del programa SWMM en el cual se modificarán distintos parámetros de la red (diámetros de conducciones y volumen de los depósitos) mediante la librería previamente desarrollada. Dicho modelo incluye las tormentas de diseño previamente obtenida teniendo en cuenta los efectos del cambio climático. 
2. Definición de las variables de decisión. En este punto se han de fijar los potenciales puntos de la red en los que podría instalarse un depósito de retención, así como sus dimensiones máximas. Igualmente, se han de definir y definir los posibles conductos a ser rehabilitados y sustituidos por otros nuevos con mayor capacidad de transporte.

3. Definición de los parámetros de las distintas funciones de coste mostradas en las ecuaciones (1), (2) y (3). Estos parámetros deben ajustarse a la realidad de la red objeto de estudio.

4. Como se ha comentado, incluso una red pequeña como la empleada como caso de estudio puede representar un problema de grandes dimensiones. Por ello, una de las partes más importantes (y novedosas) de la metodología propuesta consiste en la realización de una localización inicial de los posibles elementos a incluir en la rehabilitación. Esta pre-localización afecta tanto a posibles ubicaciones de las estructuras de almacenamiento como a los conductos a rehabilitar. Durante esta fase, los resultados son más cualitativos que cuantitativos ya que se busca ante todo la velocidad para alcanzar soluciones fiables.

5. Por último, con las posibles ubicaciones ya fijadas, se llega a un problema con unas dimensiones notablemente inferiores lo que conduce bien a tamaños de población menores, bien a mayores probabilidades de obtener soluciones mejores. En esta última fase de la optimización el objetivo es dimensionar con la máxima precisión los elementos seleccionados. El resultado de dicha optimización se presenta como resultado final de diseño de la red.

Las tres primeras fases de la metodología ya fueron presentadas por los autores en ediciones previas de este congreso (Navarro-Planas et al., [16]) y se remite a dicha publicación para más detalles. A continuación, se presentan los detalles del proceso de reducción del tamaño del problema, ya particularizado para el caso de estudio.

\section{II.4. Caso de estudio}

La metodología descrita en el apartado anterior se aplicará a la red simplificada de Chicó (Bogotá, Colombia), la cual se puede ver en la Figura 1. Esta red está dividida en 35 subcuencas (una por cada nudo de la red) y recoge las aguas pluviales de una cuenca de 51 ha. Todas las conducciones de la red son de geometría circular con diámetros que varía desde 300 a $1400 \mathrm{~mm}$. La longitud total de la red está en torno a los $5000 \mathrm{~m}$. Toda la red trabaja por gravedad debido principalmente a hallarse en las faldas de los cerros de los Andes. La diferencia de cotas entre el punto más elevado y el más bajo es de unos $40 \mathrm{~m}$.

Por su parte, la tormenta de proyecto se calculó sobre la base de los Modelos Globales de Cambio Climático propuestos por Gulizia y Camilloni [11]. Estos prevén un incremento de las precipitaciones para el horizonte 2050 en torno al $35 \%$ sobre el valor 
actual. El periodo de retorno empleado fue de 10 años y lña tormenta se determinó mediante el método de los bloques alternos.

Tras un análisis inicial de comportamiento de la red, los resultados obtenidos vaticinan un volumen de inundación total para dicha tormenta de $3835 \mathrm{~m} 3$ (un 16\% de la escorrentía total generada, $23690 \mathrm{~m} 3$ ). Esto implica que el $70 \%$ de los nudos presentan inundación en mayor o menor medida. Estos resultados son parcialmente compatibles con las observaciones realizadas en dicho distrito recientemente y se muestran en la Figura 2. En definitiva, la red se mostró insuficiente para hacer frente a posibles incrementos en el régimen de precipitaciones y se consideró adecuada para poner a prueba el método propuesto.

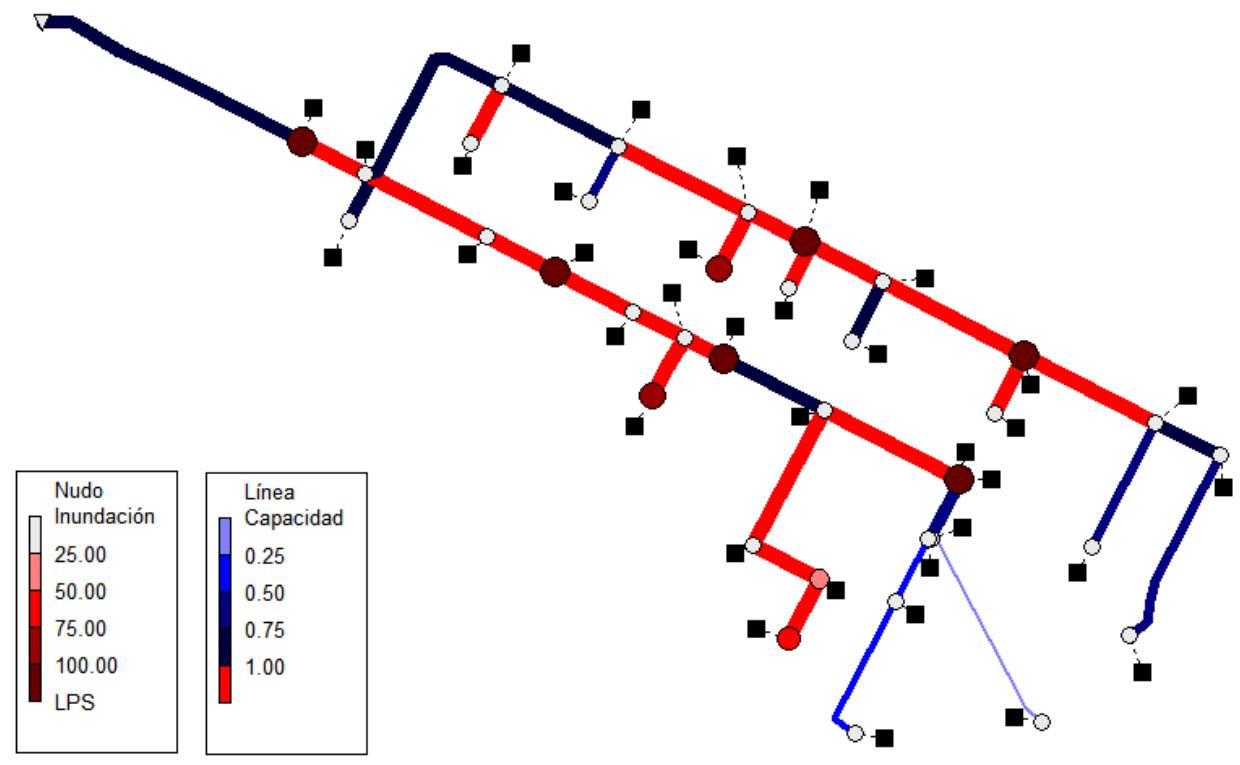

Figura 2: Resultados iniciales obtenidos antes del proceso de rehabilitación.

\section{II.5. Resultados}

Una vez detectados los posibles problemas, se procedió a buscar soluciones de rehabilitación empleando tres escenarios distintos:

1. Modificación de los diámetros de los conductos. Este escenario tiene 35 variables de decisión (las 35 conducciones de la red) cuyos diámetros se dejan como incógnitas.

2. Inclusión exclusivamente de tanques de retención, considerando 40 particiones sobre el área máxima previamente definida. Este escenario también tiene 35 
variables de decisión, correspondiente a los 35 nudos de la red en los que se puede instalar tanques de retención.

3. Estudio de rehabilitación completo, incluyendo tanto los 35 conductos como los 35 nudos. Este escenario representa un problema con $70 \mathrm{~m}$ variables de decisión y un tamaño del espacio de soluciones de $2,3 \cdot 10^{100}$, tal y como se ha comentado anteriormente.

Tras estos escenarios iniciales, se planteó la estrategia de reducción del problema. Para ello, se realizaron las siguientes operaciones:

- Se realizaron simulaciones por separado de optimización de depósitos y de conductos.

- Por una parte, partiendo del escenario 1 , se realizaron simulaciones exclusivamente modificando diámetro. En el caso de los conductos se redujo la cantidad de diámetros con el fin de reducir el tamaño del problema y así obtener soluciones en un tiempo razonable y con tamaños de población reducidos. Se realizaron 100 simulaciones distintas con el algoritmo genético. Debido al tamaño del espacio de soluciones, manejar los 100 resultados se tradujo en que prácticamente todos los conductos cambiaban en alguna ocasión. Por ello, las 100 simulaciones se clasificaron en función del valor de sus respectivas funciones objetivo. Tras esta clasificación, se seleccionaron las 10 mejores soluciones y de ellas se seleccionaron como conductos candidatos aquellos que habían cambiado en alguna ocasión. De esta forma, se pasó de 35 a 15 conductos. Para comprobar el funcionamiento del método, se realizó un proceso similar sólo con las 5 mejores soluciones, quedando en esta ocasión 8 conductos.

- Por otra parte, se realizó un proceso análogo con los depósitos de retención siguiendo las premisas del escenario 2, esto es, sin modificar ningún diámetro. En este caso y también para permitir la obtención de resultados en tiempo razonable se realizaron 10 particiones sobre la superficie total disponible para la construcción de los depósitos. Se realizaron 100 simulaciones sin modificar el diámetro de los conductos, se clasificaron en función del valor de la función objetivo y se seleccionaron las 10 mejores soluciones. De estas 10 soluciones, se seleccionaron exclusivamente aquellos nudos en cuya ubicación se proponía la instalación de tanques. Esto arrojó un total de 12 nudos. Para complementar esta selección se seleccionaron aquellos nudos donde el problema de inundación era significativo, quedando una selección final de 15 posibles ubicaciones.

- Por último, como alternativa al escenario 3 se definieron dos nuevos escenarios resultantes de combinar los depósitos y los conductos obtenidos anteriormente. En estos dos nuevos escenarios se recuperó de nuevo el problema original, con 25 posibilidades para los diámetros y 40 particiones de la superficie para los depósitos. También para estos nuevos escenarios se realizaron 100 simulaciones de cada uno para observar la repetitividad de los resultados. Los escenarios 4 y 5 se describen a continuación: 
4. Combinación de los 15 nudos seleccionados para la instalación de depósitos junto con los 15 conductos obtenidos de seleccionar las 10 mejores soluciones derivadas de sustituir solo diámetros. Esto supuso trabajar con 30 variables de decisión (15 nudos y 15 conductos).

5. Combinación de los 15 nudos seleccionados para la instalación de depósitos junto con los 8 conductos obtenidos de seleccionar las 5 mejores soluciones derivadas de sustituir solo diámetros. Esto supuso trabajar con 23 variables de decisión (15 nudos y 8 conductos).

Los resultados obtenidos en los 5 escenarios se muestran en la tabla 1:

Tabla 1: Resultados obtenidos para cada uno de los 5 escenarios realizados

\begin{tabular}{cccccc}
\hline Escenario & Función & Coste & Coste & Coste & Tamaño del \\
& Objetivo & Inundación & Depósitos & Conductos & problema \\
\hline $1(35 \mathrm{C})$ & 763,164 & 7,622 & 0 & 755,542 & $4.0 \cdot 10^{38}$ \\
$2(35 \mathrm{D})$ & 273,459 & 5,392 & 268,067 & 0 & $5.8 \cdot 10^{61}$ \\
$3(35 \mathrm{C}+35 \mathrm{D})$ & 254,046 & 8,363 & 237,457 & 8,226 & $2.3 \cdot 10^{100}$ \\
$4(15 \mathrm{D}+15 \mathrm{C})$ & 245,547 & 8,353 & 213,133 & 24,061 & $2,8 \cdot 10^{76}$ \\
$5(15 \mathrm{D}+8 \mathrm{C})$ & 218,502 & 12,701 & 186,353 & 19,448 & $4.1 \cdot 10^{69}$ \\
\hline
\end{tabular}

Tanto los resultados del escenario 4 como los del escenario 5 mejoran aquellos obtenidos sin simplificar el problema, a pesar de tener menos variables de decisión y por tanto menos opciones de mejora. Siguiendo esta misma observación, el escenario 5 (con 23 variables de decisión) obtuvo mejores resultados (tanto en mínimos absolutos como en valores medios de las soluciones) que los del resultado 4. En el escenario 4, de las 15 ubicaciones posibles sólo 4 se convierten finalmente en depósitos. De igual manera, de los 15 conductos a rehabilitar finalmente sólo 5 han de cambiar su diámetro. Resultados similares se obtienen para el escenario 5, con 3 depósitos y 4 conductos, si bien los costes asociados a la inundación resultan mayores. Aun así, a partir de la definición hecha para la función objetivo este último escenario arroja mejores resultados. La Figura 3 muestra los depósitos y conductos objeto de rehabilitación de acuerdo con los resultados del escenario 5 . 


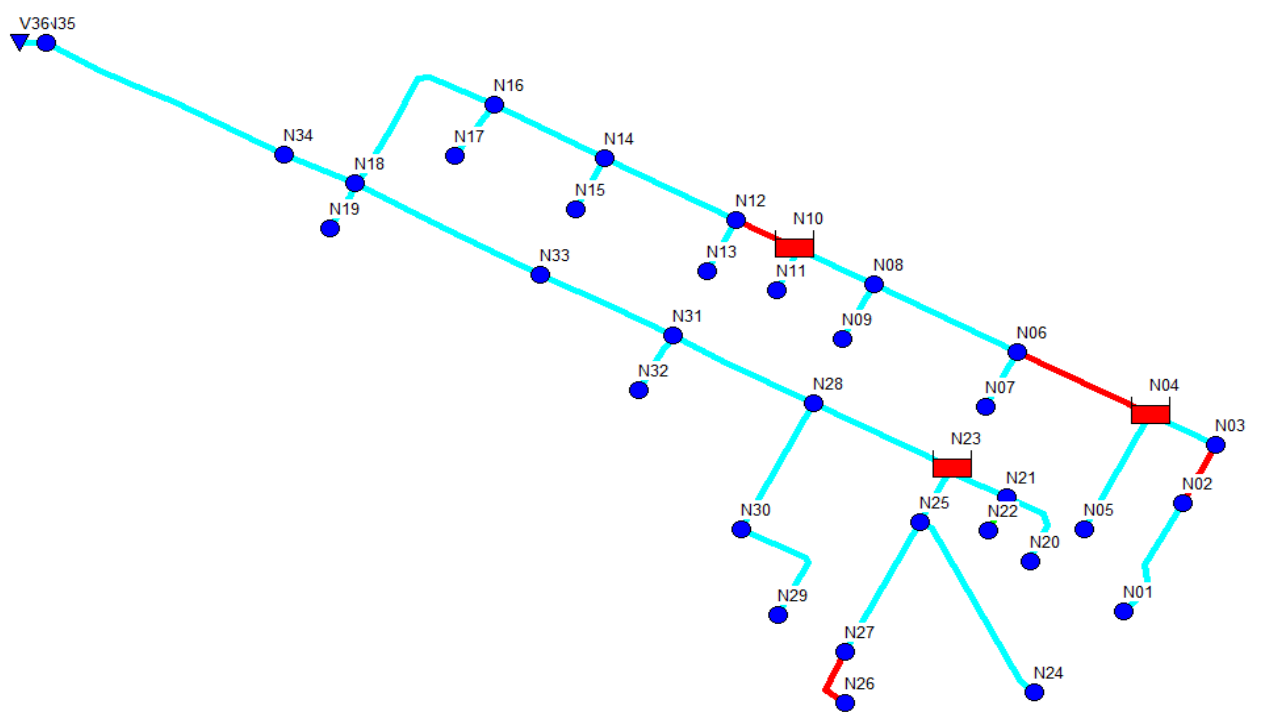

Figura 3: Resultados iniciales obtenidos antes del proceso de rehabilitación.

\section{II.6. Conclusiones}

Se ha presentado una metodología para la rehabilitación de redes de alcantarillado enfocada a compensar los efectos del cambio climático. Para ello, se ha partido de resultados previos y se han mejorado los resultados obtenidos mediante la reducción del tamaño del problema. Así se ha partido de un problema de orden $10^{100} \mathrm{y}$ finalmente se ha resuelto un problema de orden $10^{69}$ con mejores resultados (ver tabla 1). De estos resultados obtenidos en el estudio presentado es posible extraer las siguientes conclusiones:

- Se ha presentado un método eficaz para reducir el tamaño del problema de rehabilitación de redes de alcantarillado mediante la pre-localización de las ubicaciones donde se han de acometer actuaciones. En este caso las actuaciones consistían en la instalación de tanques de retención y rehabilitación de conductos.

- El número de variables de decisión se ha reducido considerablemente con respecto al número de variables de decisión iniciales, pasando de 70 a 30 y 23 en los escenarios 4 y 5, respectivamente. Esta reducción en el número de variables de decisión no ha perjudicado al objetivo del problema. Es más, al reducir el espacio de soluciones ha resultado más sencillo encontrar buenas soluciones. 
- De igual forma, los tiempos de simulación también se han reducido con respecto a los medidos para los escenarios en los que no ha habido prelocalización de las actuaciones. Esto se ha debido no sólo a la reducción del tamaño del problema, sino también al efecto que la reducción del número de variables de decisión tiene sobre parámetros del algoritmo tales como el tamaño de población o los criterios de terminación del mismo.

- A pesar de la limitación en el espacio de soluciones, los resultados obtenidos en los escenarios con reducción del tamaño del problema son mejores que los obtenidos al resolver el problema completo. Se constata que, si el problema se reduce con criterios objetivos basados en resultados previos, las soluciones mejoran. Por el contrario, si el problema se reduce de forma indiscriminada (como sucede con los escenarios 1 y 2 frente al escenario 3 ) los resultados no mejoran al dejar fuera variables de decisión que a la postre pueden resultar determinantes.

- Los resultados obtenidos no eliminan la inundación, simplemente reducen su impacto económico. Esto se debe al uso de una función de costes para los daños provocados por ésta. El uso de las funciones de coste permite convertir la inundación en un parámetro del problema y no en una restricción. Esto da la posibilidad de dejar en manos del gestor la decisión final y abre nuevas vías de desarrollo, como puede ser el uso de algoritmos multi-objetivo cuya solución no sea un valor, sino un conjunto de valores que relacionen por ejemplo costes de inversión (de ejecución efectiva) con daños asociados (sujetos a funciones estadísticas de probabilidad de precipitación).

Como conclusión final podemos afirmar que los resultados obtenidos con esta metodología son esperanzadores. Futuros desarrollos han de permitir mejorar aspectos como la eficiencia del algoritmo, esto es, la repetitividad de los resultados ante un número elevado de simulaciones. Por otra parte, en la función objetivo empleada se han mezclado costes reales con costes futuribles asociados a un evento de inundación. De ahí que otro campo de desarrollo futuro debe ser el empleo de algoritmos multi-objetivo que separen y a su vez relacionen ambos tipos de costes.

\section{II.7. Referencias}

1. Ngamalieu, U., Iglesias-Rey, P. L., Martínez-Solano, F. J., \& Saldarriaga, J. (2017). Rehabilitaciin de redes de drenaje mediante la combinación de tanques de retenciin y sustitución de conducciones (Rehabilitation of Drainage Networks Through the Combination of Retention Tanks and Replacement of Pipelines). SSRN Electronic Journal, (86111). http://doi.org/10.2139/ssrn.3113706

2. Yazdi, J., Sadollah, A., Lee, E. H., Yoo, D. G., \& Kim, J. H. (2015). Application of multi-objective evolutionary algorithms for the rehabilitation of storm sewer pipe networks. Journal of Flood Risk Management.

3. Mailhot, A., \& Duchesne, S. (2010). Design Criteria of Urban Drainage 
Infrastructures under Climate Change. Journal of Water Resources Planning and Management, 136(2), 201-208. http://doi.org/10.1061/(ASCE)WR.19435452.0000023

4. Kirshen, P., Caputo, L., Vogel, R. M., Mathisen, P., Rosner, A., \& Renaud, T. (2015). Adapting Urban Infrastructure to Climate Change: A Drainage Case Study. Journal of Water Resources Planning and Management, 141(4), 4014064. http://doi.org/10.1061/(ASCE)WR.1943-5452.0000443

5. Reyna, S. M., Vanegas, J. A., \& Khan, A. H. (1994). Construction Technologies for Sewer Rehabilitation. Journal of Construction Engineering and Management, 120(3), 467-487. http://doi.org/10.1061/(ASCE)0733-9364(1994)120:3(467)

6. Abraham, D. M., Wirahadikusumah, R., Short, T. J., \& Shahbahrami, S. (1998). Optimization Modeling for Sewer Network Management. Journal of Construction Engineering and Management, 124(5), 402-410. http://doi.org/10.1061/(ASCE)0733-9364(1998)124:5(402)

7. Mora-Melia, D., Iglesias-Rey, P. L., Martinez-Solano, F. J., \& Fuertes-Miquel, V. S. (2013). Design of Water Distribution Networks using a Pseudo-Genetic Algorithm and Sensitivity of Genetic Operators. Water Resources Management, 27(12), 4149-4162. http://doi.org/10.1007/s11269-013-0400-6

8. Rossman, L. A. (2015). Storm Water Management Model User's Manual. Cincinnaty, OH. Retrieved from http://www.epa.gov/water-research/storm-watermanagement-model-swmm

9. Martínez-Solano, F. J., Iglesias-Rey, P. L., Saldarriaga, J. G., \& Vallejo, D. (2016). Creation of an SWMM Toolkit for Its Application in Urban Drainage Networks Optimization. Water, 8(6), 1-16. http://doi.org/10.3390/w8060259

10. Sánchez-Beltrán, H., Rodríguez, C. D. M., Triviño, J. C. B., Iglesias-Rey, P. L., Valderrama, J. S., \& Martínez-Solano, F. J. (2017). Characterization of Modular Deposits for Urban Drainage Networks Using CFD Techniques. In Procedia Engineering (Vol. 186). http://doi.org/10.1016/j.proeng.2017.03.212

11. Gulizia, C., \& Camilloni, I. (2015). Comparative analysis of the ability of a set of CMIP3 and CMIP5 global climate models to represent precipitation in South America. International Journal of Climatology, 35(4), 583-595. http://doi.org/10.1002/joc.4005

12. Rossman, L. A., \& Huber, W. C. (2015). Storm Water Management Model Reference Manual Volume I - Hydrology (Vol. I). Cincinnaty, OH. Retrieved from http://www.epa.gov/water-research/storm-water-management-model-swmm

13. Mays, L. W., \& Yen, B. C. (1975). Optimal Cost Design of Branched Sewer Systems. Water Resources Research, 11(February), 37-47.

14. Meredith, D. D. (1971). Ch9. Dynamic programming concepts and applications. In Treatise on urban water systems (pp. 599-652). Fort Collins, CO: Colorado State University.

15. Moeini, R., \& Afshar, M. H. (2012). Constrained Ant Colony Optimisation 
Algorithm for the layout and size optimisation of sanitary sewer networks. Urban
Water
Journal,
(January
2015),
$1-20$.

http://doi.org/10.1080/1573062X.2012.716445

16. Navarro-Planas, V. R., Iglesias-Rey, P. L., Martínez-Solano, F. J., \& Saldarriaga Valderrama, J. G. (2016). Pseudo-genetic optimization model applied to urban storm water rehabilitation projects. In AEIPRO, 20th International Congress on Project Management and Engineering (pp. 495-507). Cartagena (España).

17. Mora-Melià, D., Gutiérrez-Bahamondes, J. H., Iglesias-Rey, P. L., \& MartínezSolano, F. J. (2016). Efficiency criteria as a solution to the uncertainty in the choice of population size in population-based algorithms applied to water Network optimization. Water, 8(12). http://doi.org/10.3390/w8120583 


\section{Appendix III}

\section{Urban drainage network rehabilitation considering storm tank installation and pipe substitution}

\section{Reference:}

Ngamalieu-Nengoue, U.A.; Iglesias-Rey, P.L.; Martínez-Solano, F.J.; Mora-Meliá, D.; Saldarriaga Valderrama, J.G. Urban Drainage Network Rehabilitation Considering Storm Tank Installation and Pipe Substitution. Water 2019, vol. 11, no. 3, pp. 515. https://doi.org/10.3390/w11030515 


\begin{abstract}
The drainage networks of our cities are currently experiencing a growing increase in runoff flows, caused mainly by the waterproofing of the soil and the effects of climate change. Consequently, networks originally designed correctly must endure floods with frequencies much higher than those considered in the design phase. The solution of such a problem is to improve the network. There are several ways to rehabilitate a network: conduit substitution as a former method or current methods such as storm tank installation or combined use of conduit substitution and storm tank installation. To find an optimal solution, deterministic or heuristic optimization methods are used. In this paper, a methodology for the rehabilitation of these drainage networks based on the combined use of the installation of storm tanks and the substitution of some conduits of the system is presented. For this, a cost-optimization method and a pseudogenetic heuristic algorithm, whose efficiency has been validated in other fields, are applied. The Storm Water Management Model (SWMM) model for hydraulic analysis of drainage and sanitation networks is used. The methodology has been applied to a sector of the drainage network of the city of Bogota in Colombia, showing how the combined use of storm tanks and conduits leads to lower cost rehabilitation solutions.
\end{abstract}

Keywords: Drainage network; climate change; rehabilitation; optimization; SWMM.

\title{
III.1. Introduction
}

One of the main problems related to urban drainage systems are the frequent flooding events in urban areas. Various factors can cause these events, such as pipe size, structural failures in the system, objects causing obstructions or an increase in rainfall intensity due to climate change inducing increased runoff flow. Climate change undoubtedly affects the intensity and frequency of meteorological phenomena of present days, including a gradual increase in rainfall intensities in many cities throughout the world, making systems initially well designed begin to fail.

In order to have a better control over the systems and prevent the occurrence of urban flooding events, many mechanisms have been implemented to reduce runoff and increase the capacity of the system. Certainly, one of the most used methods in the last years has been the implementation of storm water detention tanks (STs). These methods refer to the installation of devices in the urban area that can hold back the flow that cannot be evacuated by the system. Later, when the system has regained its transport capacity, the devices return the water to the sewerage system for correct evacuation. 
Howard [1] published one of the first works related to STs where it is established that the effectiveness of the STs combined with Wastewater Treatment Plants (WTP) to control runoff depends on STs and WTP's capacity as well as the duration and volume of the precipitation events they must control. Howard's paper also lays out the possibility of using computational tools for the analysis of these devices. His work focused on the usage of probabilistic methods based on precipitation data.

These water storage structures are built to retain a portion of the just-fallen rainwater, a portion that varies according to every storm. Di Toro and Small [2] posited a statistical method based on a probabilistic characterization of both rainwater and runoff that predicts the behavior of the storm water control devices. The long-term behavior of a ST is determined based on its size, operation method and both runoff and precipitation statistical characteristics. Based on these, Di Toro and Small studied the filling, storage and emptying of the retaining structures; flow variations caused by storm water; and first flush's implications regarding water quality.

Early ST sizing methods were based on roughly simplified methods since simulation techniques require a high computational effort in terms of time and memory. Loganathan et al. [3] presented a simplified method that could estimate ST's capacity accounting for previous storms. This method is based on exponential probability density functions for the main hydrological variables involved (runoff volumes, runoff duration, time between events). These functions are used to generate a new statistical distribution that can estimate WTP's capacity and retention volume for a given risk level. One of the main advantages of this method is that it permits us to determine the preliminary volume for an ST. With the same focus, Meredith et al. [4] developed a procedure based on all available historical data for the dimension of a runoff storage structure. The dimensioning process uses the water quality concept because all runoff must pass through the cleaning water process in the WTP. The method was tested in several industrial areas, but it is limited to small areas where rational methods can be applied.

Most of these studies were focused on the treatment of rainwater runoff before the water enters the network. Due to urban area space restrictions, alternative systems for the treatment of runoff water are needed. For this, Takamatsu et al. [5] presented the design of a rainwater storage system as part of the complementary structure of road drainage. They developed a mathematical model based on the hydraulic principals to estimate the efficiency of the pollutant elimination. The main idea was to evaluate the efficiency of a rectangular runoff ST removing suspended solids. In order to validate the mathematical model, a scaled (1/5) network model was built, on which several tests were run to study the influence of different inflows, functioning frequency and pollutant concentrations. The temporal concentration of suspended solids at the exit and the efficiency of the conceptual model were compared. They concluded that there is a correlation between the detention time and the removal efficiency.

Similar studies to Takamatsu et al. have been done to study the behavior of several draining areas under different rainfall scenarios. De Martino et al. [6] proposed 
the usage of STs as structures that enable controlling the impact of the first-rain contamination, which has the highest pollutant load. As the design of this system depends on a large number of parameters, they consider that the design is not completely defined. In order to study the influence that the rainwater might have, De Martino et al. made several simulations with different rainfall-time series in Campania (Italy). This study made an analysis of the hydrographs and pollutographs generated for several network and tank configurations. The results showed that the rainfall does not have a direct influence in the reduction of pollutant concentration. Based on this, a new methodology for the preliminary design of STs was presented.

In line with analyzing different rainfall amounts, Li et al. [7] analyzed 16 different rain events in three drainage areas. The objective of this study was to analyze the effect of a detention tank's location on the polluted load reduction, mainly particles and metals. Thus, Fu et al. [8] presented a model for optimum distribution of the STs in order to minimize the effect of new residential zones on the discharge water quality. The developed model considered three working scenarios; optimum flow control, minimization of deposit's distribution and a combination of both. A step beyond was made by Vanrolleghem et al. [9], who proposed a real time control system to manage the quality of water poured in the collectors in order to comply with the European Water Framework.

Most of the previous works about the usage of STs are focused on the issue of maximizing the quality of poured water, not to control the potential overflows that may occur due to excessive rainwater, but some studies have been carried out in order to show that STs can also reduce floods. One of the first studies that relate the usage of STs with the rainwater variation due to climate change was done by Andrés-Domenech et al. [10]. The study focused on the effects originating from changes in the rainfall regimes on the efficiency of the actual drainage systems. The proposed analytical statistical model permits us to evaluate the overflow reduction efficiency and the retention tank's volumetric efficiency as a function of the expected climate behavior and urban basins. The tank's efficiency sensitivity is evaluated under the analysis of certain changes in the precipitation. The results show the ability of STs to partially mitigate the resulting effects of climate change. Andrés-Domenech et al. based their work in the same approach as Butler and Schütze [11]: integrate simulation models to obtain an optimum control of the sanitary draining systems. For this purpose, Butler and Schütze developed a model (SYNOPSIS) consisting of a series of sub-models of the sewage network, the treatment plant and the behavior of the natural stream over which the system's evacuation will be made. These sub-models, together with a developed control module, allow the development of water control strategies in order to minimize the impact on the water evacuation. The use of simulation techniques is simple for urban wastewaters. Moreover, the simulation techniques enable water control solutions that were not possible by the classic simplified methods. This work was extended by Fu et al. [8] taking into account the optimization of urban wastewaters as a multi-objective problem. For this, they used a powerful multi-objective genetic model called NSGA II [12] that allows obtaining the Pareto's front for several optimum solutions. For the same topic, Wang et al. [13] 
proposed a two-stage optimization framework to find an optimal scheme for STs using the storm water management model (SWMM) [14]. As a result, the authors conclude that the use of STs not only reduces flooding, but also the total suspended solids.

Drainage network rehabilitation is a necessary operation to adapt an insufficient network to the new climatologic and environmental conditions. There are several ways to rehabilitate a drainage network with difficulties in the compliance of its design specifications. Traditional ones consist of pipes replaced with larger pipes. A newly developed option is the introduction of STs in the network to store water during the storm, draining it after the extreme events have passed. In this regard, Gaudio et al. [15] proposed a methodology for the hydraulic rehabilitation of urban drainage networks combining a hydraulic analysis model, a data base of rainfall events and a series of synthetic hyetographs. The results statistically analyze the possible places where the flood occurs and the influence that the roughness of the pipes can have on it.

Considering the rehabilitation using pipe replacement and other actions, Sebti et al. [16] proposed an algorithm to analyze the benefits of combining pipe substitution with other solutions installed to reduce the runoff. However, Sebti et al. did not consider hydraulic models to analyze the consequences of rehabilitation works in the network. Instead, they used the simplex algorithm for the optimization. Then, Ugarelli and Di Federico [17] calculated the economic balance between replacing damaged infrastructures or maintaining them for a certain period of time.

The rehabilitation of drainage networks based on the mere substitution of pipes is an approach that has been traditionally carried out. However, this solution is not very applicable in consolidated cities in which the replacement of large parts of the network interferes with other services already installed and generates social problems for the population such as noise, inconvenience or traffic jams. That is why this work proposes a combined use of the installation of STs and the replacement of pipes. This is intended not only to reduce investment costs, but also to minimize the impact that changes may have on citizens.

In short, the objective of this paper is to propose a methodology for the rehabilitation of drainage networks that combines the installation of STs with the replacement of pipes. To do this, the mathematical model of the network is the starting point, using SWWM to conduct the hydraulic analysis and a pseudo-genetic optimization algorithm (PGA) [18] to find the best solutions. The connection between the hydraulic calculation model and the optimization algorithm will be carried out through an adaptation of the SWMM calculation toolkit done by Martínez-Solano et al. [19] in order to reduce the calculation time.

The solution of the optimization problem requires an elevated number of decision variables (DVs) generating a large space of feasible and unfeasible solutions. This search space entails not only a big computational effort, but also may cause the method to fall at local minima, limiting the ability to find the best solution. A reduction in the size of the problem and, subsequently, in the size of the search space might help 
the convergence of the method. In this paper, a methodology for the reduction of number of DVs based on pre-selection of potential locations of STs and the selection of conduits potentially substitutable is proposed. This is a worthwhile contribution because reducing the size of the search space and improving searching mechanisms are listed as current research challenges in the application of optimization algorithms to real world problems $[20,21]$.

The methodology has been validated in several networks. Although this paper presents the results of application to the E-Chicó sector of the drainage network of Bogotá (Colombia), some model files and additional case studies can be found in the supplementary material.

\section{III.2. Problem Formulation}

In order to formulate the problem of optimizing the rehabilitation of drainage networks based on the combined use of STs and the replacement of pipes, some hypothesis had to be established:

- The computational models for the drainage networks are going to be tested with several rain scenarios, scenarios based on different climate change predictions [22].

- Potentially dangerous scenarios are the ones to be considered during the optimization process. The first selected rainfall is a synthetic design rainfall obtained from the IDF curves of 10-year return periods using the alternate block method. The second rainfall is obtained after processing the first through a climate change adaptive scenario. The rehabilitation will be carried out considering only the worst-case scenario.

- The rainfall-runoff transformation model used is the one included in the SWMM model. Specifically, the Curve Number model is used. For this, according to the characteristics of the terrain, the curve number has been specified for each of the sub catchments defined in the model.

- The drainage system models must go through a calibration process, since the analysis must be as accurate as possible. That is, the starting point of the process is a calibrated hydraulic model of the drainage network. The hydraulic model used would be SWMM. Traditionally, this type of simulation is performed considering uniform flow. However, in this case, each configuration is analyzed using the dynamic wave model, because it provides a better representation of floods than the kinetic wave model or uniform model.

- A simplification process is necessary for every model, yet the accuracy of the result must not be compromised. This simplification will highly reduce computational times for every hydraulic simulation.

- The optimization problem will be addressed in monetary units. Thus, the first step would be to find the cost functions that characterize the value of hydraulic variables in monetary units. So, the functions that together form the optimization 
total cost problem are: pipe replacement cost, ST installation cost and total flood damage cost as introduced by Cunha et al. [23].

- From all described mathematical approaches, it seems heuristics approaches can give the best advantages for the process. Therefore, based on previous experience [24], a PGA method was used.

The main objective of drainage network rehabilitation is to allow the adaptation of the network to new climatologic and environmental condition while fulfilling assigned missions. Due to that importance, it is necessary to define an adequate optimization scenario in order to optimize the process. The formulation of the problem of rehabilitation of a drainage network, combining the installation of ST and the replacement of pipes, is summarized in the flow chart of Figure 1. The first part consists of obtaining the calibrated model of the network, which is the starting point of the process. This network should represent, as faithfully as possible, the behavior of the network. Afterwards, a simple optimization process is used, with a hydraulic model based on the use of the SWMM Toolkit and a PGA that uses the levels in nodes and pipes and the flooding in nodes to determine the possible diameters of the rehabilitated conduits or the size of the installed STs. In order to define all the details of the optimization algorithm, the following sections describe the DVs, the objective function and the cost functions used.

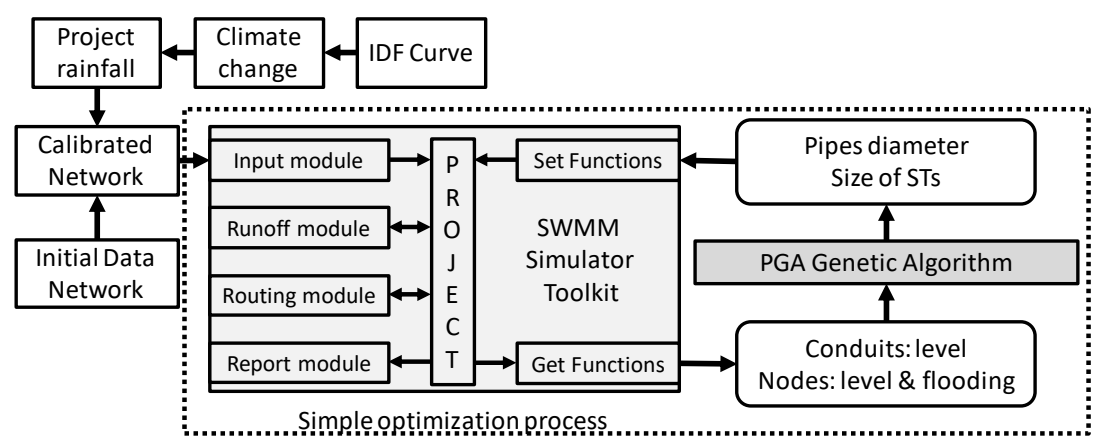

Figure 1. Flow chart of the optimization methodology based on the PGA algorithm and the toolkit of the SWMM model.

\section{III.2.1. Decision variables}

The process of rehabilitation of a drainage network (Figure 1) involves modifying two types of DVs. On the one hand, there are variables related to pipe diameters, which seek to locate the best combination of sizes to obtain the minimum flooding. The optimization model analyzes the replacement of the pipes based on their transport capacity. The diameter may increase if the original pipe is insufficient to 
transport the flowing water or decrease if a hydraulic control device [25] should be installed to introduce the same head loss as the calculated pipe's diameter. Consequently, the DV is the size of the pipes, and can vary from 0 (not replace) to a maximum value set before beginning the optimization process. Obviously, if the result associated with a pipe is 0 , it is because it is not necessary to replace it for the correct operation of the network. Then, for a better understanding of the optimization methodology, it is convenient to define some parameters related to the pipes. So, $N_{C}$ is the number of network conduits; $m$ is the number of feasible conduits selected to be replaced, varying between 1 and $N_{C}$; and $N D$ is the number of candidate diameters, between $N D_{0}$ and $N D_{\text {max }}$.

On the other hand, there are variables related to node storage capacity that seek the minimum volume of STs that reduce floods. The proposed methodology considers the possibility of installing an ST in each node of the network. This involves replacing an existing manhole with an underground ST. The land in which the rehabilitation of the drainage network is developed is mostly urban. Therefore, it is admitted that the depth of excavation is limited. Thus, the maximum depth of ST is what the manhole initially had, so the only parameter needed as DV is the ST cross section. Related to this, every node has a defined storage capacity related to its cross section and the model takes into account some nodes that could be modified into an ST. For this process, every node would have a DV representing the equivalent additional section corresponding to that of the STs in the case it would have been installed in the node location. The DV would vary between zero and a maximum value, predetermined before the optimization process and taking into account the restrictions of the urban geographical space of each node. If the nodes were not to be transformed into a tank, then the variable would have a value of 0 , meaning that, it is not adequate to install a ST on the specific node's location, maintaining thus the initial storage capacity of the node. In case the initial hydraulic model has any type of water deposit, the cross section of the deposit might be part of the optimization process.

For every node, whether it is regular or a storage node, its cross section $S$ would be expressed according to the following equation:

$$
S=A_{S} \cdot z^{B_{S}}+C_{S}
$$

Where $A_{S}, B_{S}$ and $C_{S}$ are characteristic coefficients that adjust the tank's section to different expressions, and $\mathrm{z}$ is the water level of the node. In the case of considering tanks of constant section, $A$ represents the cross section while the coefficients $B$ and $C$ are null. However, considering tanks with variable section does not imply a major difficulty in the problem implementation beyond choosing the right DVs.

Again, the definition of some parameters related to the nodes is important for the understanding of the methodology. $N_{N}$ is the number of network nodes and $n$ is the number of nodes selected to potentially install a ST, varying between 1 and $N_{N}$. Each node in which an ST can be installed has the cross section $(S)$ as DV. Since a heuristic optimization model is used, it is necessary to perform a discretization of $S$. For this 
reason, a maximum value of the tank cross section $\left(S_{\max }\right)$ is defined for each node. In this way, $N$ is the number of divisions in which $S_{\max }$ is divided. Therefore, $N$ determines the resolution of the section $S$, varying between $N_{0}$ and $N_{\max }$. A simulation performed with the ST cross section divided into $N_{0}$ parts is faster than a simulation performed $N_{\max }$ divisions. So, to obtain better calculation times, the number of divisions of the ST cross section could be reduced.

Additionally, to introduce tanks with a variable straight section does not imply major difficulty in the problem implementation beyond choosing the right DVs.

As stated before, the size of the problem is a key aspect when trying to optimize real problems. In this work, the optimization algorithm takes into consideration both pipes and nodes. The maximum size of each rehabilitation scenario can be expressed by the following equation:

$$
P S_{\max }=N_{C}{ }^{N D_{\max }} \cdot N_{N}^{N_{\max }}
$$

\section{III.2.2. Objective function}

The objective function of the optimization problem is addressed in monetary units and is represented as the sum of three cost functions:

- The investment cost related to the substitution of each selected pipe of the network.

- The investment cost linked to required volumes of STs to be installed in each solution.

- The damage cost caused by the flooding level in various nodes of the network. The mathematical expression of the objective function is given by Iglesias-Rey et al. [26]:

$$
F . O=\lambda_{1} \sum_{i=1}^{m} C\left(D_{N}(i)\right) \cdot L_{i}+\lambda_{2} \sum_{j=1}^{n} C\left(V_{D R}(j)\right)+\lambda_{3} \sum_{k=1}^{N_{F}} C\left(V_{I}(k)\right)
$$

In Equation (3), the first term represents the rehabilitation or replacement cost of the $m$ considered pipes in the network. The second term represents the construction or expansion cost of volume $V_{D R}(j)$ of the $\mathrm{n}$ STs installed in the drainage network. This cost concerns the existing STs whose volume will be expanded, and the network nodes where new STs will be installed. The third term represents the total flood damages costs [27] caused by the $N_{F}$ nodes in which a certain flooding volume $V_{I}(i)$ appears. All the terms of the objective function have a weight coefficient $\lambda_{i}$, in order to prioritize one term versus another. If $\lambda_{i}$ is minimum (eventually null) the term is not considered, but if $\lambda_{i}$ is greater, the term is considered in the objective function. 


\section{III.2.2.1. Pipe replacement Cost functions}

This function represents the cost of rehabilitation of those pipes that are replaced in the optimization process, either because they have poor internal conditions or because they have insufficient transport capacity. In this work, the proposed function is adjusted based on real data from manufacturers, relating the $\mathrm{u}_{\text {nit }}$ cost of the pipes with their diameter. Finally, the pipe substitution cost is in the form of a second-grade polynomial:

$$
C\left(D_{N}\right)=\alpha \cdot D_{N}+\beta \cdot D_{N}^{2}
$$

Where $\alpha$ and $\beta$ are coefficients that must be adjusted in each case considering the costs of the project.

\section{III.2.2.2. Storm tank installation cost functions}

This cost function links the associated investment to the installation of STs in the network. The tanks are installed on-line, simply said in series with the pipes existing in the network. The determination of this cost function is fundamental at the moment to establish the size of the adequate tanks to install. The function defines the tank installation cost based on its storage volume. Here, the idea is to build small and median tanks implying the increase of the storage capacity of the network and the water flow travelling time through the network. The mathematical expression of the cost function is:

$$
C\left(V_{D R}\right)=A+B \cdot V_{D R}^{C}
$$

In this expression, $C\left(V_{D R}\right)$ is the cost associated with the installation of an ST of volume $V_{D R}$ and $A, B$ and $C$ are coefficients that must be adjusted in each case according to the specifics of the project.

\section{III.2.2.3. Flood Damage Cost functions}

Representation of the flood cost function can be based on either total flooding volume or floods based on either total flooding volume or flood level. The first option allows us to eliminate totally the flood, but this option will need more investments. This total water volume can be obtained by summing the flooding volume of each flooding node. The second option allows reducing the flood and the cost of the flood depending on the flooding area. Lee and Kim [27] showed that flooding damage is different from flooding volume and that it was necessary to create a resilience index based on flooding damage because some subareas are immediately damaged by a certain amount of flooding while other subareas are not. They represented flood damage costs as a function of the level reached by water. 
Using the Lee and Kim approach, flood damage costs have been determined for a drainage network in Bogota (Colombia) analyzing the replacement costs of the damaged goods. A curve representing the flood cost by $\mathrm{m}^{2}$ of area as a function of the flood level was obtained for 6 different social stratums, a commercial area and an industrial area [23]. There is also a curve representing the average value of the study area. They can be observed in Figure 2.

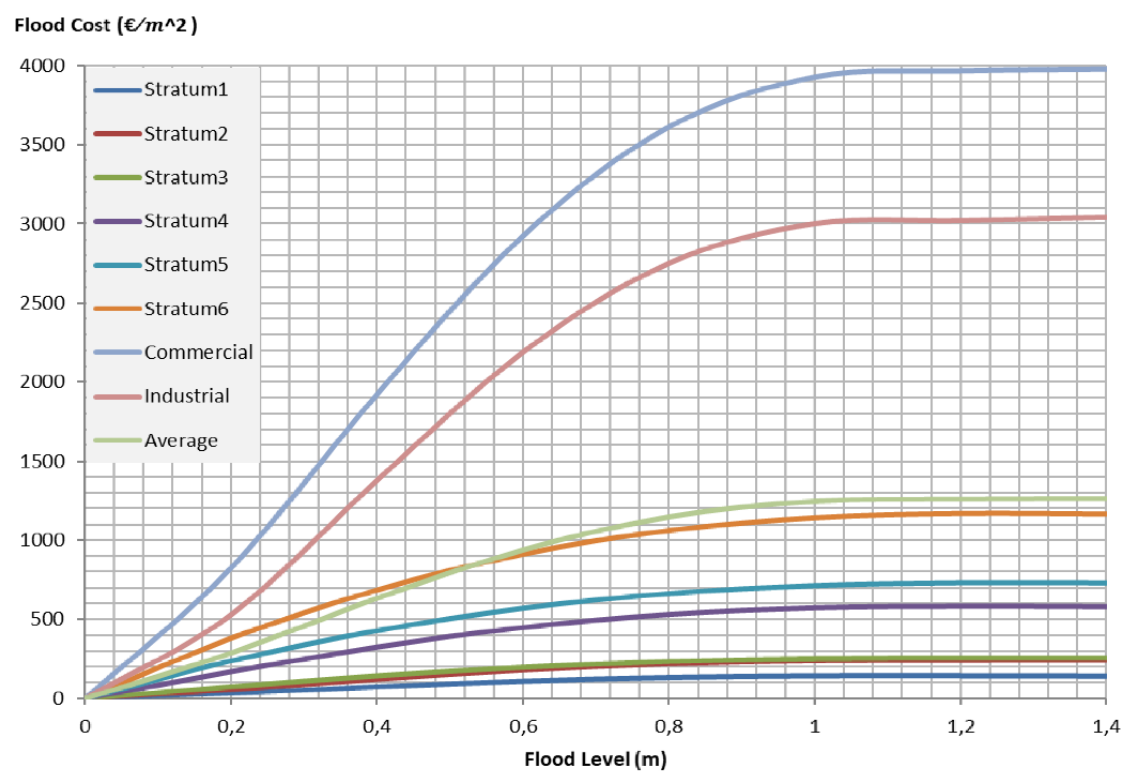

Figure 2. Flooding costs for different social Stratum linked to land uses.

The formulation of the proposed problem considers that the resulting flood cost is defined according to land use. Thus, the damage function is mathematically characterized by the expression:

$$
C(y)=C_{\max } \cdot\left(1-e^{-\lambda \frac{y}{y_{\max }}}\right)^{b}
$$

In this equation, $C_{\max }$ represents the maximum cost, when flood level $y_{\max }$ is reached. $y$ is the existing flood level in the specific node; $\lambda=4.89$ and $b=2$ are adjustment coefficients of the curve; and the parameter $y_{\max }=1.4$ is the level from which the maximal economic damage is produced. In all the cases, Equation (6) depends totally on the value of $C_{\max }$, which is presented in Table 1, for different land uses and represents the maximum per area unit. 
Table 1: $C_{\text {max }}$ values for different social Stratum (Str) linked to land uses

\begin{tabular}{lccccccccc}
\hline Land Use & Str. 1 & Str. 2 & Str. 3 & Str. 4 & Str. 5 & Str. 6 & Commercial & Industrial & Average \\
$C_{\max }\left(€ / \mathrm{m}^{2}\right)$ & 142 & 245 & 257 & 584 & 732 & 1168 & 3975 & 3041 & 1267 \\
\hline
\end{tabular}

The cost evaluation $\mathrm{C}(\mathrm{y})$ described in equation (6) required the determination of the flood level in each node. Therefore, the SWMM's ponded area model is used. This model assumes the definition of a ponded area $\left(A_{f}\right)$ in each node. In this way, the flood level is obtained as the relation between the flood volume $V_{f}$ and the area $A_{f}$.

\section{III.3. Methodology}

The optimal design or rehabilitation in drainage networks involves the search for solutions in very large spaces. Accordingly, the probability of finding minimum solutions is very small due to the immensity of SS and the existence of multiple local minima. Developments in the field of genetic algorithms (GAs) have proven to be useful in the optimization of drainage networks.

The GAs test the evolution of a random population via a parallelism that is similar to Darwin's law of natural selection. Some calibration parameters, including crossover probability, mutation probability and the population size control the optimization process. In this sense, the performance of population-based algorithms is directly related to the balance of exploration and exploitation of the SS. Traditionally, small population sizes have been related to premature convergence, since the population of the algorithm loses diversity too early, converging too early with poor solutions. Conversely, larger population sizes help ensure diversity of individuals, avoiding premature convergence, but the algorithm might waste considerable time exploring regions of the SS without any kind of interest. Consequently, parameter choice should be a trade-off between solution quality and search time. It should be noted that this work uses a modified version of classical GA, PGA, whose complete description can be found in [18].

In the same manner, the stopping criterion is important for population-based algorithms as GAs. Three genetic algorithm stopping conditions are usually found in the literature: the objective function value reaches a certain pre-defined value, a defined absolute number of generations are performed or there is no improvement in the population for $\mathrm{X}$ iterations. In this work, the third option was used, i.e., a maximal number of generations $G$ without a change in the objective function value. Considering the characteristics of the problem and based on previous experiences [25], a stopping criterion of 1000 generations without change was selected. As in the calibration of the population size, the choice of stopping criteria must prevent premature convergence, guaranteeing a good exploration and exploitation of the SS.

Additionally, it should be noted that the DVs had to be discretized. On one hand, for STs a maximum area is used, which is a function of the available surface with 
minimal urban impact and divided into partitions. Therefore, STs can be discretized in $N$ divisions $\left(N=N_{0}, \ldots, N_{\max }\right)$. On the other hand, the number of candidate pipe diameters was $N D\left(N D=N D_{0}, \ldots, N D_{\max }\right)$.

As a previous step, some algorithm tests were performed considering the full SS, i.e., all the nodes and lines of the network. According to protocol, several tests were carried out, in which it was appreciated that the space of solutions is so large that the algorithm barely finds good solutions. The enormous amount of local minimums causes the algorithm to be lost. A smaller solution space allows the optimization algorithm to find minimum values more easily.

So, this work presents a methodology for the rehabilitation of large drainage networks, reducing the SS of the problem. Additionally, this SS reduction will improve the solutions found by the PGA when the entire SS was used. The different options to reduce the SS are the following:

- Reduce the number of nodes $(n)$ in which STs could potentially be installed.

- Reduce the number of lines $(m)$ in which there could potentially be a change in diameter.

- $\quad$ Reduce the discretization $\mathrm{N}$ that is made of the section of each of the STs.

- Reduce the number of candidate diameters ND in the pipes.

The four ways to reduce the SS have been organized in a specific methodology. The complete process is summarized in Figure 3, and basically consists of three stages: the pre-location of STs, the pre-selection of conduits and the final optimization. In the following subsections, each of these stages is described in detail. 


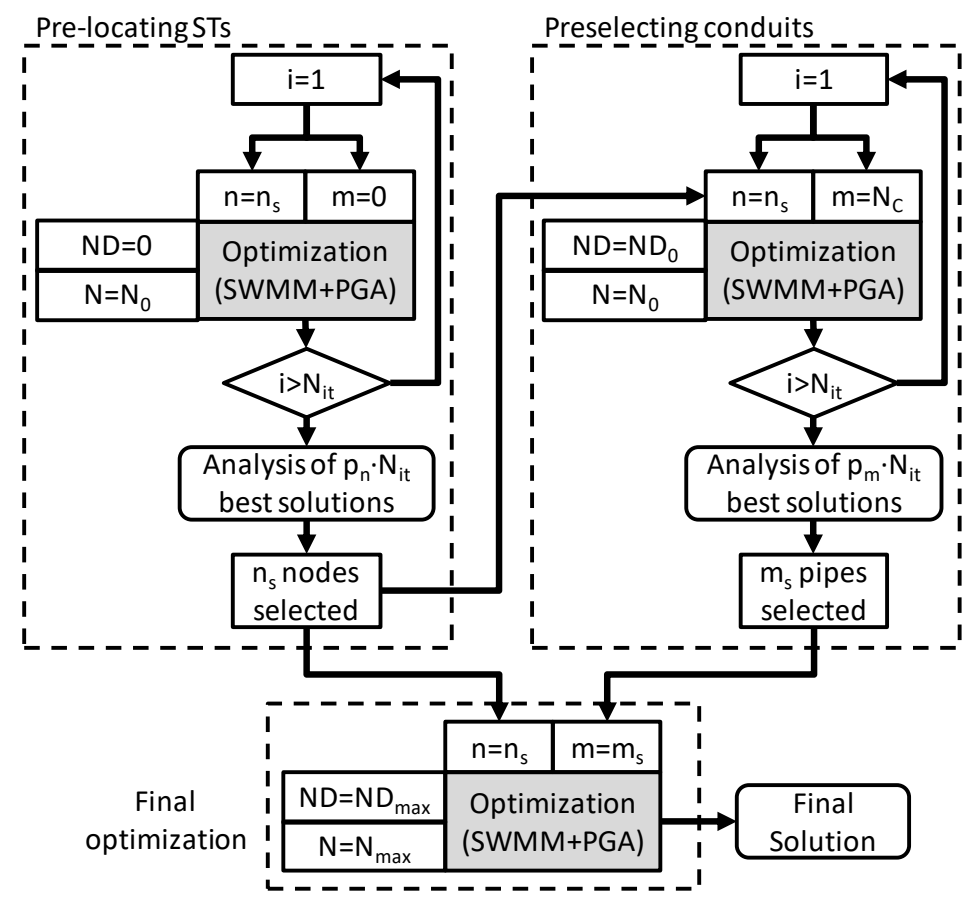

Figure 3. Block diagram of the proposed methodology.

\section{III.3.1. Pre-locating storm tanks}

There are some previous studies oriented to the pre-locating of STs [25]. However, in this case methodology described in Figure 1 is used as a basic tool to determine the possible locations of the STs. The first step of the methodology is summarized on the left hand side of Figure 3. Some runs $\left(N_{i t}\right)$ are performed with all the nodes of the network $\left(\mathrm{n}=N_{N}\right)$, but without including the diameters in the optimization process $(m=0)$. Thus, $N_{i t}$ optimizations are made, considering only the cross section (S) of the tanks as DVs and without modifying the diameters of the network. Since the objective is the reduction of the SS, the discretization of the cross sections of the tanks (S) is carried out with the smallest number of divisions $\left(N=N_{0}\right)$. This coarse discretization of each section is carried out since the objective is not to calculate its exact value, but to determine in which nodes the installation of an ST is adequate. That is, the objective of this step is selecting the nodes where STs could be installed in the rehabilitation of the network, i.e., a pre-location of STs.

In this step, the obtained solutions of initial trial runs are ranked according the value of the objective function. Each of these solutions contains a distribution of STs in the network and a dimensioning, even if approximate, of the ST size required in each node. However, the analysis is not focused on the size of the STs but on their location. 
Therefore, a percentage $p_{n}$ of the best simulations is selected. The analysis of these simulations allows identifying the nodes where an ST could be installed and a list of $n_{s}$ possible locations is created. These nodes are selected because they are repeated as the location of an ST in all the $p_{n}$ selected solutions.

\section{III.3.2. Locating lines of possible pipes substitutions}

The objective of this second step is to reduce the number of pipes in which the diameter can be modified. Another set of $N_{i t}$ optimizations is run. The DVs of each optimization are the cross section of the $n_{s}$ selected nodes in the previous process and the $N_{c}$ conduits of the network. For both types of variables the reduction of the SS is applied. Therefore, the discretization of the cross section of the tanks is the coarsest $(N$ $\left.=N_{0}\right)$ and the range of pipes available is the smallest $\left(N D=N D_{0}\right)$. In this step, the aim is to find a pre-location of pipes to be substituted.

Analogous to what happened in the previous step, an analysis of the solutions with the best value of the objective function is carried out. This analysis is not focused on the section of the tanks or on the diameter of the ducts. The analysis is centered on locating the conduits whose dimensions have been modified with respect to the initial situation.

Finally, a percentage $p_{m}$ of the best solutions are selected. The conduits selected are those that appear repeated in the solutions defined by the percentage $p_{m}$. Analyzing these solutions, the list of $m_{s}$ pipes whose replacement is repeated in the $p_{m}$ best solutions is selected.

\section{III.3.3. Final optimization, location and optimization of storm tanks and pipes diameters}

The last step considers the results of the two previous steps: the pre-location of the STs and the location of the pipes that could potentially be rehabilitated. A simulation is defined with the $n_{s}$ selected nodes and the $m_{s}$ selected lines. Although the number of DVs is smaller, the exploration of each of these variables must now be greater. Therefore, the STs are discretized to the maximum $\left(N=N_{\max }\right)$ and the list of candidate diameters for the conduits is also the largest $\left(N D=N D_{\max }\right)$. This final optimization determines the location and size of the STs to be installed and the diameters of the pipes to be rehabilitated.

In short, the reduction of SS in a problem with continuous and discrete variables has been based on two aspects: the reduction of the number of DVs and the level of detail of each of the variables. During the first two stages, the number of DVs is reduced by two with a lower level of exploration of each variable. In the final simulation, a smaller number of variables is used, but with a higher level of exploration. This reduction of the SS allows obtaining solutions to problems with large SS and multiple local minima. 


\section{III.4. Case Study}

The drainage network is called E-Chicó. It is divided into 35 hydrological subcatchments over an area of 51 hectares. All the conduits are circular with diameters between 300 and $1400 \mathrm{~mm}$, with a total length around 5000 meters. The network works completely by gravity with a maximum difference of 39.28 meters.

The diagnosis of the network and the evaluation of the possible solutions have been carried out using projected rain obtained by means of the alternative blocks method and the IDF curve. This process has been done with the original IDF curve (actual rain), the one with which the network was designed, and the one obtained after applying several climate change models [22]. As can be seen (Figure 4), the consideration of the climate change effects on the study area implies an increase in the intensity of rainfall above $45 \%$.

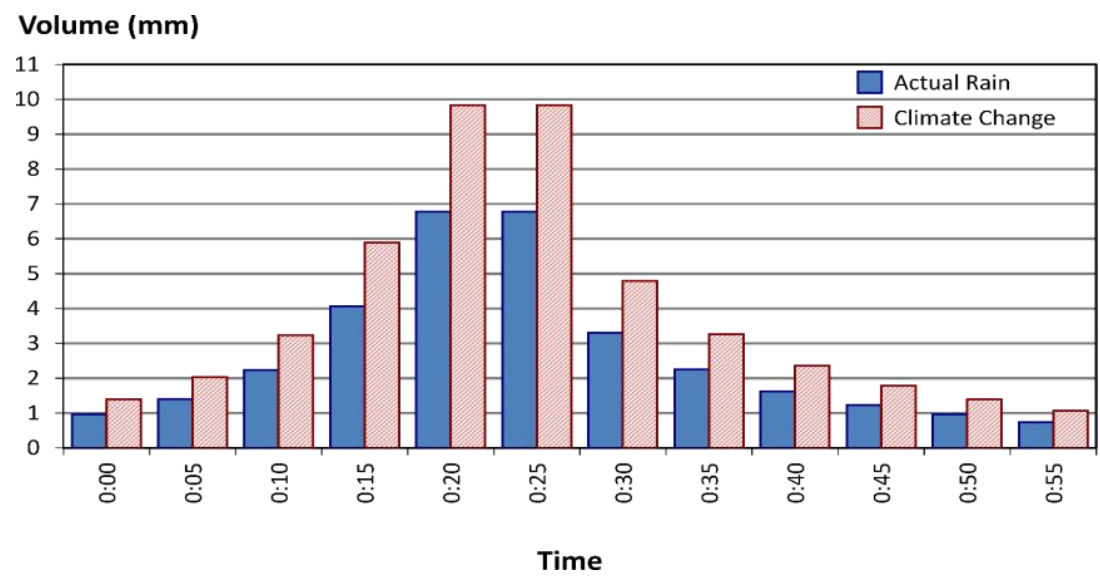

Figure 4. Alternates blocks rains: Actual and Climate Change.

The results of the first simulation considering the current IDF curve barely cause flooding in any node of the network. On the other hand, if the network is analyzed with the IDF curve obtained from climate change analysis, flooding occurs in 11 nodes of the network with a volume of $3833 \mathrm{~m}^{3}$, representing $18 \%$ of the total runoff of the network $\left(21,233 \mathrm{~m}^{3}\right)$. Figure 5 shows the nodes in which the main floods occur (flood level over $10 \mathrm{~cm}$ ), indicating the flood volume $\mathrm{V}$; the maximum level $y$ reached by the water in the node and the cost associated with flood damage. Table 2 shows the detail of the flooded nodes: the flood volume, area and level, and the damage cost obtained from Equation (6). The nodes shown in Figure 5 are highlighted in bold in Table 2. 


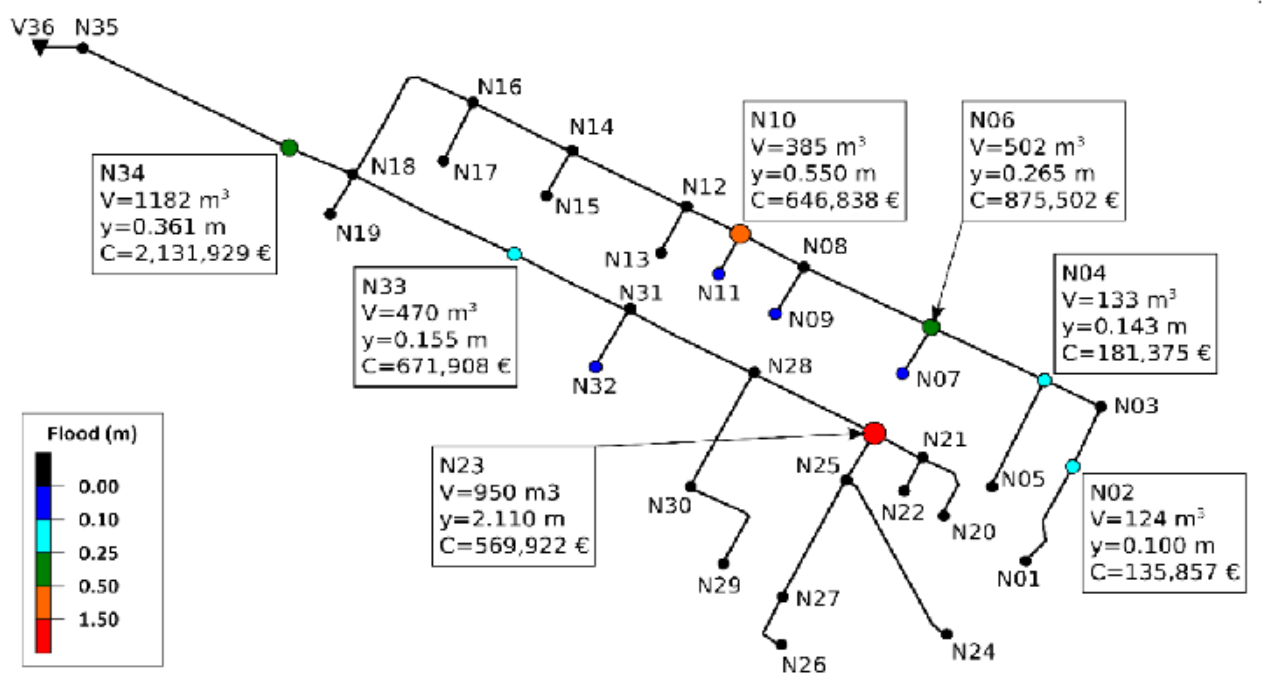

Figure 5. Representation of E-Chicó Flooding Nodes during the rainfall event.

Table 2. Data of the flooded nodes.

\begin{tabular}{ccccr}
\hline Node. & Flood volume $\left(\mathbf{m}^{3}\right)$ & Flood area $\left(\mathbf{m}^{2}\right)$ & $\mathbf{y}_{\max }(\mathbf{m})$ & \multicolumn{1}{c}{$\mathbf{C}(\boldsymbol{\epsilon})$} \\
\hline N02 & 123.56 & 1240 & 0.100 & 135,857 \\
N04 & 132.56 & 930 & 0.143 & 181,375 \\
N06 & 501.79 & 1890 & 0.265 & 875,502 \\
N07 & 23.95 & 1250 & 0.019 & 6644 \\
N09 & 1.82 & 1130 & 0.002 & 45 \\
N10 & 385.12 & 700 & 0.550 & 646,838 \\
N11 & 25.83 & 820 & 0.032 & 11,288 \\
N23 & 949.54 & 450 & 2.110 & 569,922 \\
N32 & 36.65 & 1500 & 0.024 & 12,727 \\
N33 & 469.82 & 3030 & 0.155 & 671,908 \\
N34 & 1181.87 & 3270 & 0.361 & $2,131,929$ \\
\hline TOTAL & 3832.51 & & & $5,244,034$ \\
\hline
\end{tabular}

The total cost of flood damage in the study area amounts to 5.24 million euros, which suggests the importance of rehabilitating this sector of the network and applying the proposed methodology. 


\section{III.4.1. Application of the drainage networks rehabilitation Methodology to $E$ Chico.}

In the first place, the validity of the methodology described in Figure 1 will be tested. Taking as a starting point the simulation whose results are obtained in Figure 3, three different simulation scenarios are considered:

- Scenario 1: Rehabilitation of the network based only on the modification of conduits of the network and substituted them by another with different diameter. This scenario has 35 DVs, as all the conduits are potentially changed.

- Scenario 2: Rehabilitation of the network by installing only STs. This scenario also has 35 DVs, corresponding to the 35 potential nodes in which STs can be installed. The maximum section to be installed in the tank potentially installable is defined in each node. Subsequently, the optimization method selects the cross section according to the discretization $(N)$ of this variable. It should be noted that the section minimum value corresponds to a diameter of 1.2 meters, corresponding to the cross-sectional value of a manhole.

- Scenario 3: Rehabilitation of the network combining the installation of conduits and STs. The number of DVs is 70.

In order to be able to simulate the previous scenarios, all the data described in the formulation of the problem should be defined. That is, it is necessary to specify the values of the installation cost functions of the new conduits and the investment cost for the construction of the new STs to be installed at the nodes. This involves determining the values of the parameters $\alpha$ and $\beta$ of Equation (4) and parameters $\mathrm{A}, \mathrm{B}$ and $\mathrm{C}$ of Equation (5). In this case, price databases have been used for the area where the network is located (Colombia). In this way, the values of the characteristic parameters of Equations (4) and (5) are shown in Table 3.

Table 3. Coefficients for pipes and STs cost curves.

\begin{tabular}{ccccc}
\hline$\alpha$ & B & A & B & C \\
40.69 & 208.06 & 16923 & 318.4 & 0.65 \\
\hline
\end{tabular}

At the same time, simulation of scenarios 1 and 3 requires defining a full range of pipe diameters. The full range of diameters used in this case is shown in Table 4. This table assumes a value of the parameter $N D=N D_{\max }=25$, since it must be combined with an additional state corresponding to the event of leaving the drainage line as it is in the model; that is, without rehabilitation. Table 4 also shows the installation cost of each diameter. These costs are obtained from the application of Equation (4) with the coefficients defined in Table 3. 
Table 4. Full range $\left(N D=N D_{\max }\right)$ of commercial diameters used in the example.

\begin{tabular}{ccccccccc}
\hline$D(\mathrm{~mm})$ & 300 & 350 & 400 & 450 & 500 & 600 & 700 & 800 \\
$C(\epsilon / \mathrm{m})$ & 30.93 & 39.73 & 49.56 & 60.44 & 72.36 & 99.31 & 130.43 & 165.71 \\
\hline$D(\mathrm{~mm})$ & 900 & 1000 & 1100 & 1200 & 1300 & 1400 & 1500 & 1600 \\
$C(\epsilon / \mathrm{m})$ & 205.15 & 248.75 & 296.51 & 348.43 & 404.51 & 464.76 & 529.16 & 597.73 \\
\hline$D(\mathrm{~mm})$ & 1800 & 1900 & 2000 & 2200 & 2400 & 2600 & 2800 & 3000 \\
$C(\epsilon / \mathrm{m})$ & 747.35 & 828.4 & 913.61 & 1096.52 & 1296.07 & 1512.27 & 1745.11 & 1994.6 \\
\hline
\end{tabular}

The results of the optimization of the first three scenarios will allow comparing the effect of carrying out the rehabilitation of the drainage network by different methods. The results will show the benefits of rehabilitation through the combined use of STs and the replacement of pipes. One of the main conclusions obtained from this first analysis is the time necessary to complete the simulations due to the high number of DVs and the wide of solutions space. In addition, after performing numerous simulations, a large dispersion in the results was also observed. Additionally, it could be concluded that the combination of diameter changes and ST installation gave better results than the optimization of any of them separately.

For the Scenario 3 corresponding to the rehabilitation of the whole network, some previous simulations have been performed with the following characteristics: $n=$ $35, m=35, N=40$ and $N D=25$. The best objective function value obtained was 268,292 $€$, corresponding to the substitution of 21 pipes and the installation of 16 STs. Afterwards, a sensitivity analysis with different population sizes and different maximum number of generations was done, but no improvement was obtained.

So, the presented methodology has undergone an improvement process in order to obtain optimal results without the need to significantly modify the parameters of the genetic algorithm used to perform the simulations. Since these parameters are estimated based on the number of DVs and the complexity of the problem, the objective was now focused on reducing the number of nodes and lines that can be modified.

\section{III.4.2. Application of the solution space reduction Methodology to E-Chicó}

The application of the proposed methodology (Figure 3) to the E-Chicó network begins with the process of pre-locating STs. The parameters used in this process are:

- The number of simulations defined is one hundred $\left(N_{i t}=100\right)$.

- The discretization of the ST area is reduced to its minimum value $\left(N=N_{0}=10\right)$.

- Only the sections of the tanks potentially to be installed in the nodes of the network are considered as DVs $\left(n=N_{N}=35\right)$.

- No conduit can be modified during the process $(m=0)$. 
- The basic parameters of the PGA algorithm, population size $\left(N_{p o p}\right)$ and the end criterion based on a number of generations $\left(N_{g e n}\right)$ without change, are fixed at 100.

Once all the simulations have been carried out, the percentage $p_{n}$ of solutions with the best value in the objective function is selected. In short, the 10 best solutions are selected. In each one, it is analyzed in which nodes an ST is installed. This generates a list of pre-locations of STs in the network. In this case, this list contains a total of 15 possible locations of the STs. In Figure 6, the shaded cells represent the selected nodes.

\begin{tabular}{|l|l|l|l|l|l|l|}
\hline N01 & N02 & N03 & N04 & N05 & N06 & N07 \\
\hline N08 & N09 & N10 & N11 & N12 & N13 & N14 \\
\hline N15 & N16 & N17 & N18 & N19 & N20 & N21 \\
\hline N22 & N23 & N24 & N25 & N26 & N27 & N28 \\
\hline N29 & N30 & N31 & N32 & N33 & N34 & N35 \\
\hline
\end{tabular}

Figure 6. Selected nodes as STs' pre-location.

In order to validate the methodology of pre-localization of STs, the previous process has been repeated, but by expanding the discretization of the tank area to the maximum value $\left(N=N_{\max }=40\right)$. The results obtained lead to the same list of selected nodes as indicated in Figure 6.

The second stage of the SS reduction process is the pre-selection of conduits. For this, the pre-location of STs from the previous stage is used and a reduction in the number of potentially substitutable pipes is sought. The parameters used in this process are:

- The number of simulations is the same as in the previous stage $\left(N_{i t}=100\right)$.

- The DVs are the areas of the ns nodes selected in the first stage and the diameters of all the conduits $\left(n=N_{C}=35\right)$ of the network.

- The discretization of the area of the STs is kept at the minimum value, as it happened with the previous stage of the process.

- The basic parameters of the PGA algorithm are the same as in the previous phase $\left(N_{\text {pop }}=100, N_{\text {gen }}=100\right)$.

- Instead of using the full range of diameters (Table 4), a range of reduced diameters is used, the details of which can be seen in Table 5. This table shows the diameters $D$ of the reduced range and the unit costs $(C)$ obtained from the application of the cost function (4) with the parameters of the Table 3 . Note that although Table 5 only has 9 values, the number of options for the DV is $N D=10$. This additional value corresponds to the option of not taking any action on the pipe. 
Table 5. Reduced diameter range $\left(N D=N D_{0}=10\right)$

\begin{tabular}{cccccccccc}
\hline $\mathrm{D}(\mathrm{mm})$ & 300 & 400 & 600 & 800 & 1000 & 1200 & 1500 & 1800 & 2000 \\
$\mathrm{C}(€ / \mathrm{m})$ & 30.93 & 49.56 & 99.31 & 165.7 & 248.74 & 348.43 & 529.16 & 747.35 & 913.61 \\
\hline
\end{tabular}

Once the simulations have been carried out, it has been decided to define two different conduit pre-selections. One is considering a probability of $10 \%$ of the best solutions $\left(p_{m 1}=10 \%\right)$ and another one considering only $5 \%$ of solutions with a lower value of the objective function $\left(p_{m 2}=5 \%\right)$. The preselected lines in each case are shown in Figure 7. In the left part of the figure, the values corresponding to $10 \%$ are collected, highlighting the preselected lines by gray color. On the right hand side, the pipes selected for $5 \%$ of the best solutions obtained in this process are represented in an analogous way.

\begin{tabular}{|l|l|l|l|l|l|l|}
\hline P01 & P02 & P03 & P04 & P05 & P06 & P07 \\
\hline P08 & P09 & P10 & P11 & P12 & P13 & P14 \\
\hline P15 & P16 & P17 & P18 & P19 & P20 & P21 \\
\hline P22 & P23 & P24 & P25 & P26 & P27 & P28 \\
\hline P29 & P30 & P31 & P32 & P33 & P34 & P35 \\
\hline \multicolumn{6}{c|}{$p_{m 1}=10 \%$}
\end{tabular}

\begin{tabular}{|l|l|l|l|l|l|l|}
\hline P01 & P02 & P03 & P04 & P05 & P06 & P07 \\
\hline P08 & P09 & P10 & P11 & P12 & P13 & P14 \\
\hline P15 & P16 & P17 & P18 & P19 & P20 & P21 \\
\hline P22 & P23 & P24 & P25 & P26 & P27 & P28 \\
\hline P29 & P30 & P31 & P32 & P33 & P34 & P35 \\
\hline \multicolumn{5}{|c}{$p_{m 2}=5 \%$}
\end{tabular}

Figure 7. Selected lines to potentially be replaced for $p_{m l}=10 \%$ and $p_{m 2}=5 \%$.

The pre-selection of ducts has been tested to validate performing the same simulations but using the full range of diameters $\left(N D=N D_{\max }=25\right)$. The results obtained, in terms of the lines that would be pre-selected, are the same as those obtained in the case of using only the reduced range $\left(N D=N D_{0}=10\right)$.

In short, the process of conduits pre-selection leads to select 15 pipes in case of selecting $10 \%$ of the best solutions or only 8 lines when the $5 \%$ of best simulations is considered. At this moment, the final stage of the process is the final optimization. In this phase, the reduction of the SS is used: 15 possible locations of STs and 8 or 15 possible lines to be rehabilitated. Therefore, the analysis of the network requires the definition of two new scenarios:

- Scenario 4: Rehabilitation of the network combining the possible installation of STs in the 15 selected nodes and the 15 conduits that can be substituted.

- Scenario 5: It is the same scenario as the previous one (scenario 4), with the difference that the number of potentially replaceable conduits is only 8 . 


\section{III.4.3. Results analysis}

The results obtained from the optimization in the five scenarios considered are shown in Table 6. In each scenario, the following values appear: the number of DVs (nodes in which STs can potentially be installed and lines where their diameter could potentially be modified), the value of the objective function (divided into flood costs, investment costs in STs and investment costs in pipes), the number of elements to install of each type (STs and conduits) and the size of the SS of the problem. The scenario that offers the worst results (scenario 1) would be classic rehabilitation based solely on the replacement of pipes. The solution based on the use of STs has better results than the rehabilitation based on pipe substitution (scenario 2). However, the combined use of pipe substitution and installation of STs is shown as the best option of all (scenario 3).

Table 6. Results summary of E Chico Optimization Process.

\begin{tabular}{ccccccccc}
\hline \multirow{2}{*}{ Scenario } & \multicolumn{2}{c}{ No. DVs } & Objective & \multicolumn{2}{c}{ Terms in the objective function } & \multicolumn{2}{c}{$\begin{array}{c}\text { No. elements in the } \\
\text { solution }\end{array}$} \\
& Nodes & Lines & Function & Floods & STs & Pipes & STs & Pipes \\
\hline 1 & 0 & 35 & 791,214 & 24,753 & 0 & 766,461 & 0 & 21 \\
2 & 35 & 0 & 273,455 & 5,392 & 268,063 & 0 & 6 & 0 \\
3 & 35 & 35 & 268,292 & 20,238 & 230,087 & 17,968 & 4 & 4 \\
5 & 15 & 15 & 245,547 & 8,353 & 213,133 & 24,061 & 4 & 5 \\
\hline
\end{tabular}

Comparing the solutions that use joint rehabilitation pipes-STs, it is observed that the reduction of the SS significantly improves the solutions. That is, pre-location of STs and pre-selection of conductions reduce the SS in an amount that allows a better exploration. Therefore, according to Table 6 , the best solution is the one proposed by scenario 5, which considers the installation of $3 \mathrm{STs}$ and the replacement of 3 conduits. As it is observed, the reduction of the SS between scenario 3 and scenarios 4 and 5 is many orders of magnitude, which helps to explain the improvement in the solutions.

The methodology used assesses the flood economically. Therefore, the solutions of scenarios 4 and 5 present flood costs (8353 and 12,701 respectively). These flood costs correspond to nodes whose flood level does not exceed $1.5 \mathrm{~cm}$. However, from the point of view of the function defined in Equation (6), any level of flooding has an associated cost. Additionally, Tables 7 and 8 present the results of the flood nodes for scenarios 4 and 5 . As can be seen, the cost of flooding is not zero. However, both flood volumes $\left(52.77\right.$ and $75.78 \mathrm{~m}^{3}$ ) and flood levels are very low. Therefore, from a practical point of view it can be considered that the solutions are acceptable. 
Table 7. Flooding results in scenario 4.

\begin{tabular}{ccccc}
\hline Node & Flood volume $\left(\mathrm{m}^{3}\right)$ & Flood area $\left(\mathrm{m}^{2}\right)$ & $\mathrm{y}_{\max }(\mathrm{m})$ & $\mathrm{C}(€)$ \\
\hline N10 & 3.77 & 700 & 0.013 & 307.94 \\
N32 & 12.96 & 1500 & 0.010 & 1680.29 \\
N33 & 36.04 & 3030 & 0.009 & 6364.57 \\
TOTAL & 52.77 & & & $8,352.80$ \\
\hline
\end{tabular}

Table 8. Flooding results in scenario 5.

\begin{tabular}{ccccc}
\hline Node & Flood volume $\left(\mathbf{m}^{3}\right)$ & Flood area $\left(\mathbf{m}^{2}\right)$ & $\mathbf{y}_{\max }(\mathbf{m})$ & $\mathbf{C}(\boldsymbol{\epsilon})$ \\
\hline N02 & 12.82 & 1240 & 0.013 & 3024.66 \\
N03 & 10.82 & 1080 & 0.010 & 1619.42 \\
N32 & 12.96 & 1500 & 0.009 & 1681.56 \\
N33 & 36.08 & 3030 & 0.012 & 6775.01 \\
TOTAL & 75.78 & & & $12,700.64$ \\
\hline
\end{tabular}

Figure 8 represents the location of the STs obtained in scenario 5, as well as their size. Also, the flooded nodes are represented (blue nodes). Additionally, the figure represents the lines that have been necessary to modify and the size of the new conduits. It should be noted that in the case of conduits T04 and T10, the solution obtained involves the installation of a diameter smaller than the original one. This clearly indicates the need to install in these sections a resistant element (a gate or an orifice) that introduces a head loss equivalent to the one that involves the installation of the new smaller diameter.

The installation of control devices in drainage networks allows the accumulation of water in certain points of the network, decreasing the time of concentration downstream, and thereby reducing flooding. This is why this "hydraulic control" is one of the techniques that is often used to improve the efficiency of STs. In this case, the appearance of solutions, such as those of conduits T04 and T10, supposes the need to install a gate or an orifice at the outlet of the STs that introduces a certain head loss. This head loss must be such that the equivalent capacity of the original pipeline together with the control device used is equal to the transport capacity of the calculated pipeline.

In short, two of the three STs installed should have hydraulic control. Therefore, these tanks must have a control element at the exit that contains the avenue of water in 
the tanks and reduces the water travel time towards the downstream sections. If Figure 8 is compared with Figure 5, the installation of the STs together with the hydraulic control elements allows not only a reduction of flooding upstream, but also control of flooding that occurred in nodes downstream from these STs (i.e., nodes N31 and N34).

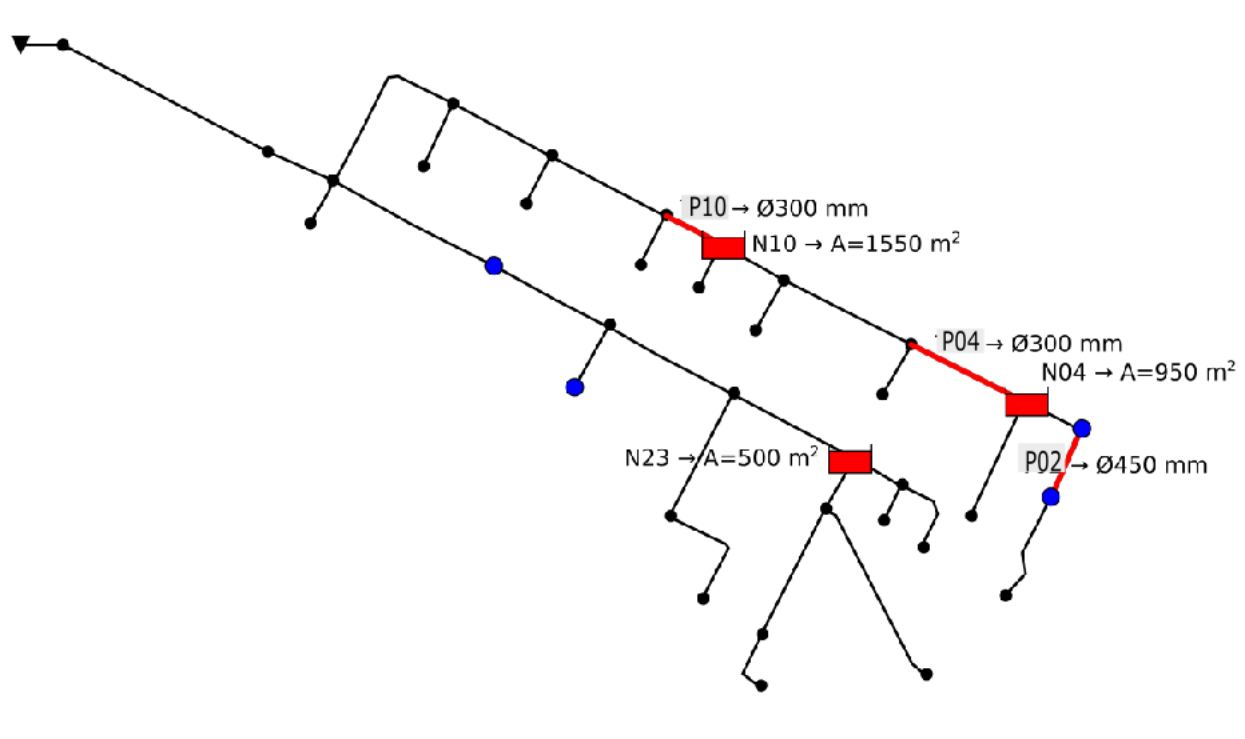

Figure 8. Representation of STs installed and pipes to replace according to scenario 5 results.

Simulations with a larger number of DVs are usually associated with a longer calculation time. However, the real difficulty of a problem is expressed by its size $\left(P S_{\max }\right)$ according to Equation (2). Therefore, in Table 9 the size of the problem of each scenario is presented. The table also includes a measurement of the calculation time, expressed as the number of times it is necessary to evaluate the objective function.

As can be seen, the larger the size of the problem, the greater the number of evaluations of the objective function required to find the solution. It is for this reason that the use of an SS reduction technique and reduction of the size of the problem has been effective. 
Table 9. Size problem and computation time of the different scenarios.

\begin{tabular}{cccc}
\hline Scenario & No. DVs & $\begin{array}{c}\text { Problem } \\
\text { Size }\end{array}$ & $\begin{array}{c}\text { No. Evaluations of the } \\
\text { Objective function }\end{array}$ \\
\hline 1 & 35 & $4.0 \cdot 10^{38}$ & 51,200 \\
2 & 35 & $5.8 \cdot 10^{61}$ & 65,485 \\
3 & 70 & $2.3 \cdot 10^{100}$ & 709,000 \\
4 & 30 & $2.8 \cdot 10^{76}$ & 205,300 \\
5 & 23 & $4.1 \cdot 10^{69}$ & 151,300 \\
\hline
\end{tabular}

The reduction in the number of DVs allows a better exploration of the SS, which means the smaller the number of decision variables, the better the solution found. However, reducing the number of DVs entails another effect. Simulations performed with large numbers of DVs cause a large dispersion of solutions, while solutions obtained with fewer DVs offer a much narrower range of solutions. Thus, Figure 9 represents a comparison of the solution variability range offered in scenarios 3, 4 and 5. It shows on the $\mathrm{X}$-axis the relation between the value of the objective function in a simulation and the minimum global value for this scenario. On the $\mathrm{Y}$-axis is represented the frequency of the different solutions obtained with respect to the minimum value obtained. That is, the more vertical the curve, the greater concentration of solutions. On the contrary, if the slope of the curve is smaller, it indicates that there is a greater dispersion of the solutions. Suppose that a value of 1.5 is set as a reference (the solution obtained has a maximum extra cost of $50 \%$ over the optimal solution). In that case, only $37 \%$ of the solutions obtained with scenario 3 are below that level. In the case of scenario 4, 66\% of solutions present a cost smaller than 1.5 times the minimum value of the objective function. For scenario 5 , this percentage is even greater $(81 \%)$. In short, the reduction of the SS not only allows obtaining better solutions but at the same time it makes the range of good solutions (solutions close to the minimum) greater. 


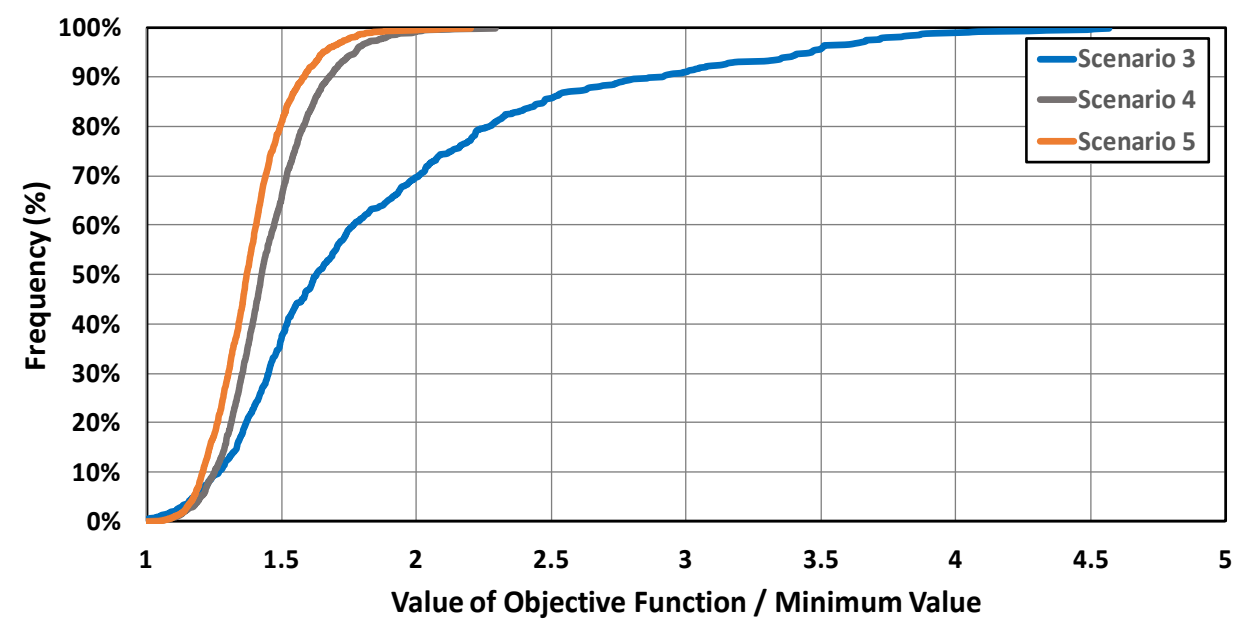

Figure 9. Comparison between the whole problem results and methodology application results.

\section{III.4.3. Sensitivity analysis of the SS reduction}

The main uncertainty is whether the SS reduction methodology could affect the final solution. It must be borne in mind that STs pre-localization and conduits preselection were performed using the PGA algorithm with a population size $N_{p o b}=100$ and a termination criterion $N_{g e n}=100$. In order to validate the selection, a sensitivity analysis of the selection process of STs and conduits has been carried out. The process of reducing the SS was repeated with different values of $N_{p o p}$ and $N_{\text {gen }}$. The different values of the population size were $35,50,75,100$ and 300 elements, while the values used as finalization criteria were 50,100 and 150 generations without a change in the value of the objective function. The results obtained are shown in the following figures.

In Figure 10, the nodes that could potentially be a ST location are collected for each combination of values of $N_{p o p}$ and $N_{g e n}$. On the other hand, Figure 11 shows the lines potentially replaceable. In both cases, the node or line selected has been indicated with an $\mathrm{X}$ in the corresponding cell. 
Id of the nodes in which a storage structure is installed

\begin{tabular}{|c|c|c|c|c|c|c|c|c|c|c|c|c|c|c|c|c|c|c|c|c|c|c|c|c|c|c|c|c|c|c|}
\hline \multicolumn{2}{|c|}{$\mathrm{N}_{\text {pop }} \mathrm{N}_{\text {gen }}$} & 1 & 2 & 3 & 4 & 5 & 6 & 7 & 8 & 9 & 10 & 11 & \begin{tabular}{|l|}
12 \\
\end{tabular} & 13 & \begin{tabular}{l|l}
14 & 15
\end{tabular} & 16 & 17 & 18 & \begin{tabular}{l|l}
19 & 20
\end{tabular} & \begin{tabular}{|l|l|}
21 & \\
\end{tabular} & \begin{tabular}{l|l}
22 & 23
\end{tabular} & \begin{tabular}{|l|l} 
& 24 \\
\end{tabular} & \begin{tabular}{|l|l|}
5 & 26 \\
\end{tabular} & \begin{tabular}{|l|l|}
27 & \\
\end{tabular} & \begin{tabular}{l|l}
28 & 2 \\
\end{tabular} & \begin{tabular}{l|l}
9 & 30
\end{tabular} & 31 & \begin{tabular}{l|l}
32 & 3 \\
\end{tabular} & 33 & \begin{tabular}{l|l}
34 & 35 \\
\end{tabular} \\
\hline \multirow{3}{*}{35} & 50 & & $\mathbf{x}$ & $\mathbf{X}$ & $\mathbf{X}$ & $x$ & $\mathrm{X}$ & $x$ & & $x$ & $\mathbf{X}$ & $x$ & $\mathrm{X}$ & & $X$ & & & $X$ & & & $x$ & & & & & $x$ & $\mathbf{X}$ & $\mathrm{X}$ & & \\
\hline & 100 & $x$ & $\mathrm{X}$ & $x$ & $x$ & & $\bar{x}$ & $x$ & & $x$ & $\mathbf{x}$ & $x$ & $x$ & & $x$ & & & $\bar{x}$ & & & $x$ & & & & & & $\mathbf{X}$ & $\bar{x}$ & & $\bar{x}$ \\
\hline & 150 & $x$ & $\mathbf{X}$ & $\mathbf{X}$ & $\mathbf{X}$ & $x$ & $x$ & $x$ & & & $\mathbf{X}$ & $\mathbf{X}$ & $x$ & & & & & $x$ & & & $x$ & & & & & & & $\mathbf{X}$ & $\mathbf{X}$ & $\bar{x}$ \\
\hline \multirow{3}{*}{50} & 50 & $x$ & $x$ & $x$ & $\mathbf{x}$ & $x$ & $x$ & $x$ & $x$ & & $\mathrm{x}$ & $\mathbf{x}$ & $\mathbf{x}$ & $\mathrm{X}$ & & $x$ & & $\mathrm{X}$ & & & $\mathrm{X}$ & & & & & & & & $\mathbf{x}$ & $x$ \\
\hline & \begin{tabular}{|l|}
100 \\
\end{tabular} & $x$ & $\mathbf{x}$ & $x$ & $x$ & & $x$ & $x$ & $x$ & $x$ & $\mathbf{X}$ & $\mathbf{X}$ & $x$ & & & $\mathbf{x}$ & & $x$ & & & $x$ & & & & & & & 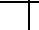 & & \\
\hline & 150 & & $\mathbf{x}$ & $x$ & $\mathrm{X}$ & & $x$ & $x$ & $x$ & $\mathrm{x}$ & $\mathbf{x}$ & $x$ & $x$ & & & & & & & & $\mathrm{X}$ & & & & & & & $x$ & & $\bar{x}$ \\
\hline \multirow{3}{*}{75} & 50 & $\mathrm{x}$ & $\mathrm{x}$ & & $\mathbf{x}$ & $\mathrm{X}$ & $\mathrm{x}$ & $\mathrm{x}$ & $\mathrm{x}$ & $\mathrm{x}$ & $\mathbf{x}$ & $\mathrm{X}$ & & $X$ & & & & $\mathrm{X}$ & & & $\mathrm{X}$ & & & & & & & $\begin{array}{ll}x \\
\end{array}$ & $\mathbf{x}$ & $\bar{x}$ \\
\hline & 100 & & $x$ & & $\mathbf{x}$ & $x$ & $x$ & $x$ & $x$ & $x$ & $\mathbf{x}$ & $x$ & & $x$ & & & & $x$ & & & $x$ & & & & & & & $x$ & $\mathrm{x}$ & $x$ \\
\hline & 150 & $\mathbf{x}$ & $x$ & & $\mathbf{x}$ & $x$ & $\mathrm{x}$ & $x$ & $\mathrm{x}$ & $x$ & $\mathbf{x}$ & & & & & & & $x$ & & & $x$ & & & & & & & $\mathrm{X}$ & & $x$ \\
\hline \multirow{3}{*}{100} & 50 & $\mathbf{x}$ & $\mathrm{x}$ & $x$ & $x$ & & $x$ & $x$ & $\mathrm{x}$ & $\mathrm{x}$ & $\mathbf{x}$ & $\mathrm{X}$ & & & $x$ & & & $\mathrm{X}$ & & & $\mathrm{X}$ & & & & & & & $\mathbf{x}$ & $\mathbf{x}$ & 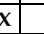 \\
\hline & 100 & $\mathbf{X}$ & $\mathbf{X}$ & $\mathbf{X}$ & $\mathrm{X}$ & & \begin{tabular}{|l|}
$x$ \\
\end{tabular} & $\mathrm{x}$ & $\mathbf{x}$ & & $\mathbf{X}$ & $x$ & & & $\bar{x}$ & & & $x$ & & & $x$ & & & & & & & \begin{tabular}{l|l|}
$\mathbf{X}$ \\
\end{tabular} & \begin{tabular}{l|l}
$\mathbf{x}$ \\
\end{tabular} & $\bar{x}$ \\
\hline & \begin{tabular}{|l|}
150 \\
\end{tabular} & & $x$ & $\mathbf{X}$ & $\mathbf{X}$ & $x$ & $\mathbf{x}$ & $\mathrm{X}$ & $x$ & & $\mathbf{X}$ & $x$ & & & & & & & & & $x$ & & & & & & & $x$ & & $\bar{x}$ \\
\hline \multirow{3}{*}{300} & 50 & & $x$ & $\mathbf{x}$ & $x$ & & $\mathrm{x}$ & $\mathrm{x}$ & & & $\mathbf{X}$ & & & & & & & $x$ & & & $x$ & & & & & & & & $\mathrm{x}$ & $x$ \\
\hline & 100 & & $x$ & & $x$ & & $\mathrm{x}$ & $x$ & $x$ & & $\mathbf{x}$ & $x$ & & & & & & & & & $x$ & & & & & & & & & $x$ \\
\hline & 150 & & $x$ & & $x$ & & $x$ & & $x$ & & $\mathbf{X}$ & $x$ & & & & & & & & & $x$ & & & & & & & & & $\bar{x}$ \\
\hline
\end{tabular}

Scenario

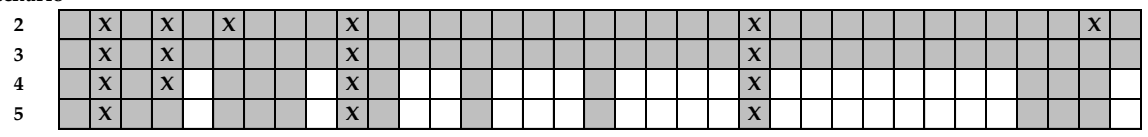

Figure 10. Sensitivity analysis results for pre-located STs with different $N_{p o p}$ and NGen.

Id of the conduit in which a storage structure is installed

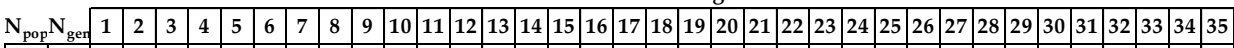

\begin{tabular}{|c|c|c|c|c|c|c|c|c|c|c|c|c|c|c|c|c|c|c|c|c|c|c|c|c|c|c|c|c|c|}
\hline \multirow{3}{*}{35} & \begin{tabular}{|l|}
50 \\
\end{tabular} & & $x$ & $x$ & $x$ & $\mathbf{X}$ & $\mathbf{x}$ & & $\mathbf{X}$ & $\mathbf{x}$ & & $\mathbf{X}$ & $\mathrm{x}$ & $\mathbf{x}$ & $\mathbf{X}$ & $x$ & $\mathbf{X}$ & $x$ & & $\mathbf{x}$ & & & $x$ & & & & $x$ & $x$ & \\
\hline & 100 & $x$ & $X$ & $x$ & $X$ & $\mathbf{X}$ & $\mathbf{X}$ & $x$ & $X$ & 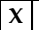 & $\mathbf{X}$ & $X$ & & & & & & & & & & & $X$ & & & & & $X$ & $x$ \\
\hline & 150 & & $\mathrm{X}$ & $\mathrm{X}$ & $X$ & $\mathbf{X}$ & $\mathrm{X}$ & & & & $\mathbf{X}$ & $X$ & & $\mathbf{X}$ & & $\mathrm{x}$ & & & & & & $\mathbf{x}$ & $\mathbf{X}$ & & $x$ & & & $\mathbf{X}$ & $X$ \\
\hline \multirow{3}{*}{50} & 50 & & $x$ & $x$ & $x$ & & $\mathbf{x}$ & $x$ & $\mathbf{x}$ & $x$ & $\mathbf{x}$ & $x$ & & $\mathbf{X}$ & & & $\mathbf{x}$ & $x$ & & $x$ & $\mathbf{x}$ & & $x$ & & & & & $x$ & \\
\hline & 100 & & $x$ & $x$ & $x$ & & $\mathbf{x}$ & $x$ & $\mathbf{X}$ & $\mathbf{x}$ & $\mathbf{x}$ & $X$ & & & & & & & & & $\mathbf{X}$ & & $\mathrm{X}$ & & & & & & $X$ \\
\hline & 150 & & $X$ & $\mathrm{X}$ & $x$ & & $\mathbf{X}$ & $X$ & $\mathbf{X}$ & & $\mathbf{x}$ & $X$ & $\mathbf{x}$ & $X$ & & $\mathbf{X}$ & & & & & & $\mathbf{X}$ & 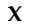 & $X$ & & $\mathbf{X}$ & & $\mathrm{X}$ & \\
\hline \multirow{3}{*}{75} & 50 & & $X$ & $x$ & $x$ & & $\mathbf{x}$ & $X$ & $\mathbf{X}$ & & $\mathbf{X}$ & $\mathbf{X}$ & $\mathbf{x}$ & $\mathbf{X}$ & & & $\mathbf{X}$ & $x$ & & $\mathbf{x}$ & & & $\mathbf{X}$ & $X$ & & & & $\mathbf{X}$ & $X$ \\
\hline & 100 & & $x$ & $x$ & $x$ & $\mathbf{X}$ & $\mathbf{x}$ & $x$ & $\mathbf{X}$ & $\mathbf{x}$ & $X$ & & $\mathbf{x}$ & $X$ & & & $\mathbf{x}$ & $x$ & & & $\mathbf{x}$ & & $\mathrm{X}$ & & & & & & $X$ \\
\hline & 150 & & $X$ & $\mathrm{X}$ & $x$ & $\mathbf{X}$ & $\mathbf{x}$ & $x$ & $\mathbf{X}$ & $\mathbf{X}$ & $\mathbf{X}$ & & $\mathbf{x}$ & $\mathbf{X}$ & $\mathbf{X}$ & & & & & & & & $\mathbf{X}$ & & & & & $x$ & $X$ \\
\hline \multirow{3}{*}{100} & 50 & & $X$ & $\mathrm{X}$ & $X$ & $\mathbf{X}$ & $\mathbf{x}$ & $X$ & $\mathbf{X}$ & $\mathbf{X}$ & $\mathbf{X}$ & $\mathbf{X}$ & & $X$ & & & & $X$ & & $\mathbf{x}$ & $\mathbf{X}$ & & $X$ & & & $X$ & & $X$ & $X$ \\
\hline & 100 & & $X$ & $x$ & $X$ & & $\mathbf{x}$ & $X$ & & $\mathbf{x}$ & $\mathbf{X}$ & $X$ & & $X$ & & $\mathbf{x}$ & & & & & & & & & & & & & \\
\hline & 150 & & $X$ & $x$ & $x$ & & $\mathrm{X}$ & $X$ & $\mathbf{X}$ & $\mathbf{x}$ & $\mathbf{X}$ & & & $\mathbf{X}$ & & $\mathrm{X}$ & $\mathbf{X}$ & & & & $\mathbf{X}$ & & $\mathbf{X}$ & $X$ & & & & & $X$ \\
\hline \multirow{3}{*}{300} & 50 & & $x$ & $x$ & $\mathbf{x}$ & & $\mathbf{x}$ & & $\mathbf{X}$ & $x$ & $\mathbf{x}$ & $x$ & & $\mathbf{X}$ & & & $\mathbf{X}$ & $x$ & $x$ & & $\mathbf{x}$ & & $x$ & & & $X$ & & $\mathbf{X}$ & \\
\hline & 100 & & $x$ & $\mathbf{x}$ & $x$ & & $\mathbf{x}$ & $x$ & $\mathbf{X}$ & $x$ & $\mathbf{x}$ & 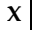 & $\mathbf{x}$ & $X$ & & & $\mathbf{x}$ & $x$ & & & $\mathbf{X}$ & & $x$ & & & & & & \\
\hline & 150 & & $X$ & & $x$ & & $\mathbf{x}$ & $x$ & $x$ & $\mathbf{X}$ & $\mathbf{X}$ & $X$ & & $\mathbf{X}$ & & & & $X$ & $X$ & $\mathbf{x}$ & $\mathbf{X}$ & $\mathbf{X}$ & $\mathbf{X}$ & $X$ & & & & & $X$ \\
\hline
\end{tabular}

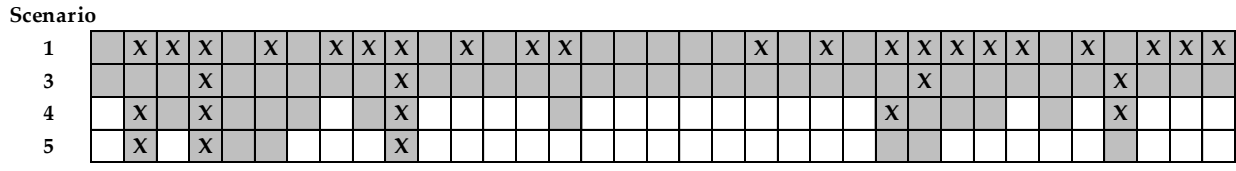

Figure 11. Sensitivity analysis results for pre-selecting conduits with different $N_{\text {pop }}$ and

$N_{\text {Gen. }}$ 
The sensitivity analysis of Figures 10 and 11 validates the SS reduction methodology based on the pre-location of STs and the pre-selection of conduits. In the lower part of Figure 10, the DVs used in each scenario are indicated by a shaded cell, and X indicates the nodes that finally provide a solution for the installation of a ST. The nodes that finally appear as solutions in the scenarios are those that had been selected mostly in the process of pre-selection of STs. In short, regardless the value of $N_{p o p}$ and $N_{\text {gen }}$ the preselected nodes would have been almost the same, and in any case those that appear in the final solutions of scenarios 3, 4 and 5 would have always been selected.

Something similar happens in the case of pre-selection of conduits. Figure 11 shows the results of the sensitivity analysis and the results of scenarios 1, 3, 4 and 5. As in Figure 10, the DVs used are indicated as shaded cells, and the lines that are finally replaced are indicated with an X. The results show that the lines selected for different values of $N_{p o p}$ and $N_{g e n}$ are almost the same. That is, selected lines are those that are finally found in the final solutions of scenarios 3, 4 and 5. Moreover, $N_{p o p}$ and $N_{g e n}$ parameters have no influence on the pre-location of STs or on the pre-selection of pipes. Therefore, the SS reduction methodology can be considered reliable.

\section{III.5. Conclusions}

The proposed methodology for the rehabilitation of drainage networks, based on the combined use of STs and the replacement of conduits, has been shown to be effective in solving the problems of insufficient drainage networks. Despite the effectiveness of the presented methodology, a certain disparity is detected in the obtained solutions due to the enormous size of the SS. Therefore, a complementary strategy that allows the reduction of SS is presented. Once the methodologies area applied to the case study, it is possible to extract the following conclusions:

- The increase in rainfall intensities caused by climate change causes originally well-designed networks to present flooding problems. The use of STs has been shown as an effective technique to solve this problem. However, the effectiveness of this method is even greater when it is combined with the rehabilitation of some pipes of the drainage network. The results shown by scenarios 1, 2 and 3 presented above show how the combined action of STs and pipe renewal (scenario 3 ) is much more effective than the isolated action of any of the other two actions (scenarios 1 and 2).

- The number of DVs required for the rehabilitation of a drainage network can be very high. This may cause (Figure 9) the optimization model to give solutions that are quite dispersed and sometimes far from the optimal values required. It is well known that the importance of meta-heuristic algorithms does not lie in the optimality of their solutions, but in the ability to obtain large sets of good solutions. That is why the disparity of solutions observed with large numbers of DVs can become a problem. 
- An alternative methodology has been proposed for the reduction of the SS that permit us to locate solutions that are better and less dispersed than those obtained with the initial model. This methodology is based on the pre-location of STs and the pre-selection of possible conduits. The methodology uses the PGA developed, reducing the SS by using a smaller discretization of the size of the STs, a smaller range of diameters of pipes, and a smaller number of elements (tanks and pipes). The final result has proven to be effective for the cases analyzed, not only because it reduces SS and computing times, but also because it obtains better solutions (scenario 4 and 5). Likewise, the solutions obtained with the scenarios that use a reduced SS (scenarios 4 and 5) are much more concentrated and less dispersed (Figure 9) than those obtained initially.

- The SS reduction methodology in the case study has been shown to be reliable and stable since variations in the $N_{\text {pop }}$ and $N_{\text {gen }}$ parameters of the PGA model hardly modify the preselected lines and nodes.

The best solutions suggest the suitability of installing control devices as a strategy to improve the operation of drainage networks. These control elements are static: either orifices or gates in a fixed position. In the solutions of scenarios 4 and 5, the installation of STs is complemented with the presence of this devices at the exit of the ST. This additional hydraulic resistance has been represented by a conduit with a diameter lower than the original one. As indicated previously, this type of operation helps to increase the concentration times in the critical nodes of the network.

The methodology based on the use of STs is adequate for the rehabilitation of drainage networks. The optimization model and the SS reduction methodology allow obtaining good solutions to a really complex problem. The resolution methodology used in the E-Chicó network can be extended to any type of drainage network, since the approach of the method has been so general to be easily extrapolated to other cases.

The extrapolation of the method to other networks generates some interesting uncertainties, such as the possible behavior of drainage networks with pumping stations. In this case, where the network has already installed pumping systems, the start and stop levels of the pumps and the size of the suction tank can be defined as DV. In the case of installing new pumping systems, the DVs would be the flows to be evacuated by each pump. In this case, it would be necessary to include in the objective function the investment cost associated with the construction of the new pumping equipment. In any case, it seems that the exposed methodology would be applicable to this situation.

It should be noted that the best solutions do not always eliminate the presence of floods in the network. In the case that solutions without flood are desirable, there are two possibilities. The first one is to allocate higher costs to the presence of floods that shift the optimum to solutions where the installation of STs or new conduits is profitable. The second option would be to run the problem statement from a multi-criteria point of view. With this type of approach, one could determine the level of investment required for each level of expected flood damage. 


\section{III.6. References}

1. Howard, C.D.D. Theory of Storage and Treatment-Plant Overflows. J. Environ. Eng. Div. 1976, 102, 709-722.

2. di Toro, D.M.; Small, M.J. Stormwater Interception and Storage. J. Environ. Eng. Div. 1979, 105, 43-54.

3. Loganathan, V.G.; Deniur, J.W.; Segarra, R.I. Planning Detention Storage for Stormwater Management. J. Water Resour. Plan. Manag. 1985, 111, 382-398.

4. Meredith, D.D.; Middleton, A.C.; Smith, J.R. Design of Detention Basins for Industrial Sites. J. Water Resour. Plan. Manag. 1990, 116, 586-591.

5. Takamatsu, M. Hydraulic model for sedimentation in storm-water detention basins. J. Environ. 2009, 136, 527-534.

6. de Martino, G.; de Paola, F.; Fontana, N.; Marini, G.; Ranucci, A. Pollution Reduction in Receivers: Storm-Water Tanks. J. Urban Plan. Dev. 2011, 137, 29 38.

7. Li, Y.; Kang, J.-H.; Lau, S.-L.; Kayhanian, M.; Stenstrom, M.K. Optimization of Settling Tank Design to Remove Particles and Metals. J. Environ. Eng. 2008, 134, 885-894.

8. Fu, G.; Butler, D.; Khu, S.T. Multiple objective optimal control of integrated urban wastewater systems. Environ. Model. Softw. 2008, 23, 225-234.

9. Vanrolleghem, P.; Benedetti, L.; Meirlaen, J. Modelling and real-time control of the integrated urban wastewater system. Environ. Model. Softw. 2005, 20, 427-442.

10. Andrés-Doménech, I.; Montanari, A.; Marco, J.B. Efficiency of Storm Detention Tanks for Urban Drainage Systems under Climate Variability. J. Water Resour. Plan. Manag. 2012, 138, 36-46.

11. Butler, D.; Schütze, M. Integrating simulation models with a view to optimal control of urban wastewater systems. Environ. Model. Softw. 2005, 20, 415-426.

12. Deb, K.; Pratap, A.; Agarwal, S.; Meyarivan, T. A fast and elitist multiobjective genetic algorithm: NSGA-II. IEEE Trans. Evol. Comput. 2002, 6, 182-197.

13. Wang, M.; Sun, Y.; Sweetapple, C. Optimization of storage tank locations in an urban stormwater drainage system using a two-stage approach. J. Environ. Manag. 2017, 204, 31-38.

14. Rossman, L.A. Storm Water Management Model User's Manual; U.S. Environmental Protection Agency: Cincinnati, OH, USA, 2015.

15. Gaudio, R.; Penna, N.; Viteritti, V. A combined methodology for the hydraulic rehabilitation of urban drainage networks. Urban Water J. 2016, 13, 644-656.

16. Sebti, A.; Bennis, S.; Fuamba, M. Cost Optimization of Hydraulic and Structural Rehabilitation of Urban Drainage Network. J. Infrastruct. Syst. 2014, 20, 04014009. 
17. Ugarelli, R.; di Federico, V. Optimal Scheduling of Replacement and Rehabilitation in Wastewater Pipeline Networks. J. Water Resour. Plan. Manag. 2010, 136, 348356.

18. Mora-Melia, D.; Iglesias-Rey, P.L.; Martinez-Solano, F.J.; Fuertes-Miquel, V.S. Design of Water Distribution Networks using a Pseudo-Genetic Algorithm and Sensitivity of Genetic Operators. Water Resour. Manag. 2013, 27, 4149-4162.

19. Martínez-Solano, F.J.; Iglesias-Rey, P.L.; Saldarriaga, J.G.; Vallejo, D. Creation of an SWMM Toolkit for Its Application in Urban Drainage Networks Optimization. Water. 2016, 8, 1-16.

20. Maier, H.R.; Kapelan, Z.; Kasprzyk, J.; Kollat, J.; Matott, L.S.; Cunha, M.C.; Dandy, G.C.; Gibbs, M.S.; Keedwell, E.; Marchi, A.; et al. Evolutionary algorithms and other metaheuristics in water resources: Current status, research challenges and future directions. Environ. Model. Softw. 2014, 62, 271-299.

21. Mala-Jetmarova, H.; Sultanova, N.; Savic, D. Lost in optimisation of water distribution systems? A literature review of system operation. Environ. Model. Softw. 2017, 93, 209-254.

22. Gulizia, C.; Camilloni, I. Comparative analysis of the ability of a set of CMIP3 and CMIP5 global climate models to represent precipitation in South America. Int. J. Climatol. 2015, 35, 583-595.

23. Cunha, M.C.; Zeferino, J.A.; Simões, N.E.; Saldarriaga, J.G. Optimal location and sizing of storage units in a drainage system. Environ. Model. Softw. 2016, 83, 155166.

24. Mora-Melia, D.; Iglesias-Rey, P.L.; Martinez-Solano, F.J.; Ballesteros-Pérez, P. Efficiency of Evolutionary Algorithms in Water Network Pipe Sizing. Water Resour. Manag. 2015, 29, 4817-4831.

25. Leitão, J.P.; Carbajal, J.P.; Rieckermann, J.; Simões, N.E.; Marques, A.S.; de Sousa, L.M. Identifying the best locations to install flow control devices in sewer networks to enable in-sewer storage. J. Hydrol. 2018, 556, 371-383.

26. Iglesias-Rey, P.L.; Martínez-Solano, F.J.; Saldarriaga, J.G.; Navarro-Planas, V.R. Pseudo-genetic Model Optimization for Rehabilitation of Urban Storm-water Drainage Networks. Procedia Eng. 2017, 186, 617-625.

27. Lee, E.; Kim, J. Development of Resilience Index Based on Flooding Damage in Urban Areas. Water 2017, 9, 428. doi:10.3390/w9060428.

\section{III.7. Supplementary Material}

A) Additional study cases that reinforce the conclusions of the work. 
One of the main challenges of meta-heuristic algorithms is that they are able to include all the features of real-world problems. However, the formulation problem of the complete system is complex, both because of the large number of decision variables that can be considered and because of the numerous constraints to satisfy. Obviously, as an increasing number of decision variables and choices, so does the size of the search space and find (near) global optimum solutions becomes exceptionally difficult. Offering a methodology to reduce the space of solutions is one of the contributions of this paper.

Obviously, a single case study may not be enough to prove the efficiency of the methodology. In this regard, most researchers demonstrate the goodness of their proposal on benchmarking networks widely studied in the literature, and finally apply their conclusions about a real case. However, the benchmarking networks available in the rehabilitation of drainage systems are scarce and not excessively complex. Consequently, it does not make sense to reduce the search space for a type of network that does not really need it.

As indicated in the main text (lines 164-167) the methodology with several networks has been validated. In order to be able to show the validity of the methodology in this document, the results of two networks are presented as supplementary material: a Basic network and the Ayurá network.

\section{Case 1: Basic Network: 7 nodes and 6 conduits}

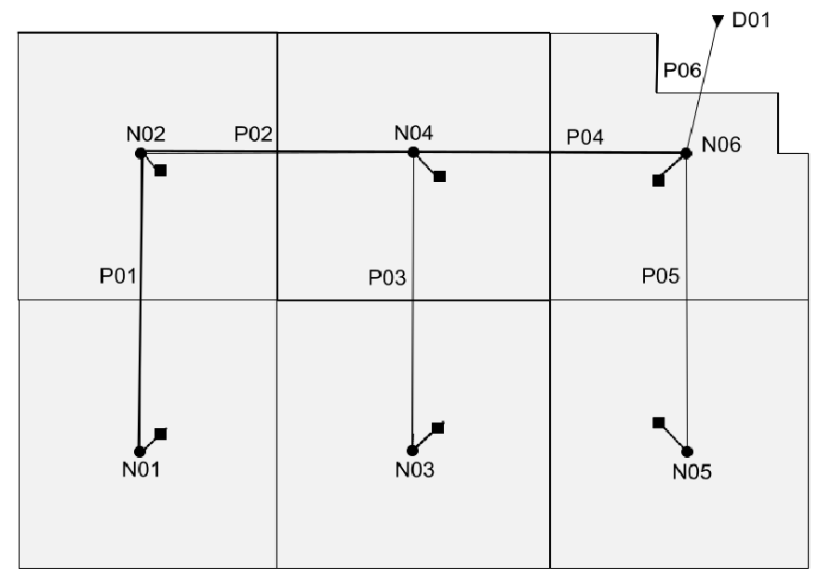

The application of the rehabilitation methodology generates 3 scenarios:

- Scenario 1: replacing ducts only

- Scenario 2: only installation of STs

- Scenario 3: installation of STs and rehabilitation of pipelines 


\begin{tabular}{ccccccccc}
\hline Scenario & \multicolumn{2}{c}{ No. DVs } & $\begin{array}{c}\text { Objective } \\
\text { Function } \\
\text { Costs }\end{array}$ & Floods & STs & Posts of the objective function & \multicolumn{2}{c}{$\begin{array}{c}\text { No. elements in the } \\
\text { Solution }\end{array}$} \\
\hline 1 & 0 & 6 & 446,854 & 15,982 & 0 & 430,872 & 0 & 6 \\
2 & 6 & 0 & 263,601 & 3,719 & 259,881 & 0 & 6 & 0 \\
3 & 6 & 6 & 247,239 & 6,484 & 184,651 & 56,104 & 4 & 2 \\
\hline
\end{tabular}

The main results are those indicated in the following table. As the size of the network is low, it is not necessary to apply the SS reduction technique. However, it can be seen how the results are consistent with the conclusions of the paper.

\section{Case 2: Ayurá Network: 73 nodes and 86 conduits}

In this case, the size of the network suggests the convenience of applying the SS reduction described in main text. That is why 5 scenarios have been generated:

- Scenario 1: replacing ducts only

- Scenario 2: only installation of STs

- Scenario 3: installation of STs and rehabilitation of pipelines

- Scenario 4: reduction of the SS of scenario 3 considering a percentage of solutions of $10 \%$.

- Scenario 5: reduction of the SS of scenario 3 considering a percentage of solutions of $5 \%$. 


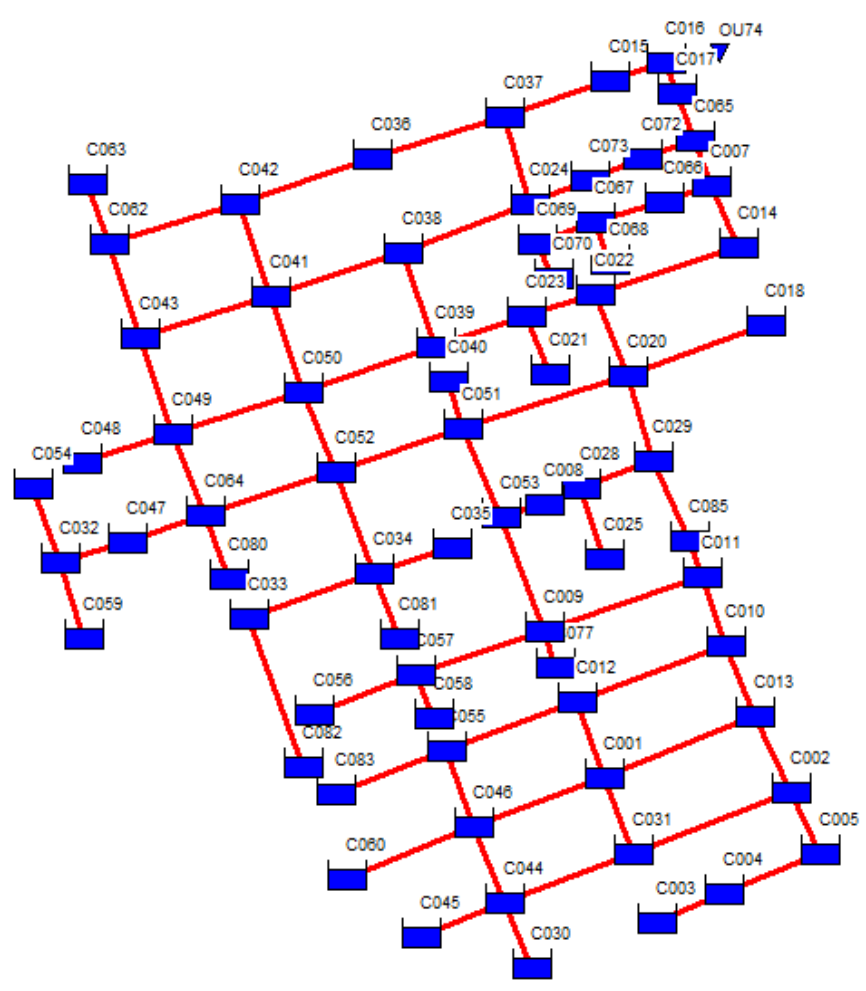

\begin{tabular}{ccccccccc}
\hline \multirow{2}{*}{ Scenario } & \multicolumn{2}{c}{ No. DVs } & Objective & \multicolumn{2}{c}{ Terms in the objective function } & \multicolumn{2}{c}{$\begin{array}{c}\text { No. elements in } \\
\text { the solution }\end{array}$} \\
& Nodes & Lines & Function & Floods & STs & Pipes & STs & Pipes \\
\hline 1 & 0 & 86 & 392,599 & 11,278 & 0 & 381,321 & 0 & 56 \\
2 & 73 & 0 & 518,916 & 46,934 & 471,982 & 0 & 15 & 0 \\
3 & 73 & 86 & 387,864 & 10,831 & 316,464 & 60,569 & 8 & 22 \\
4 & 29 & 47 & 384,521 & 11,725 & 276,287 & 96,509 & 7 & 28 \\
5 & 29 & 39 & 356,462 & 4,270 & 286,176 & 66,016 & 7 & 22 \\
\hline
\end{tabular}

The main results are those indicated in the following table. As in the previous case, the results are consistent with the conclusions presented. Moreover, the reduction of SS is again effective in improving the solutions. 
B) Data of the case study presented in the work.

The data can be pasted directly into a text file and saved as * inp. This allows to have the complete network in epanet format.

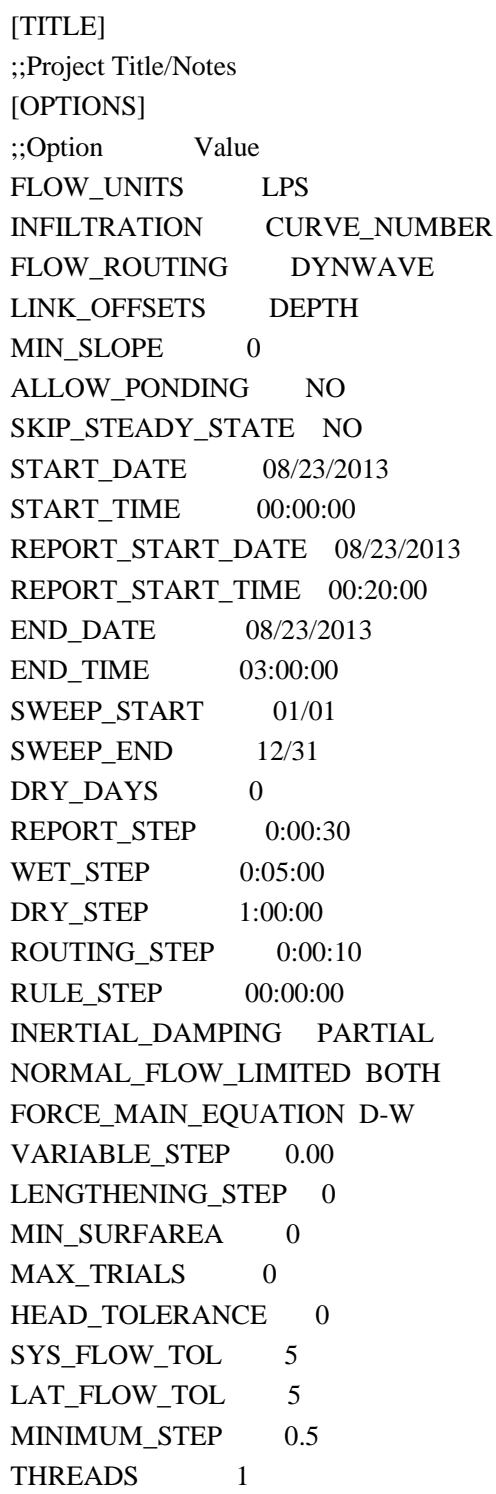


[EVAPORATION]

;;Data Source Parameters

\begin{tabular}{|c|c|}
\hline CONSTANT & 0 \\
\hline DRY_ONLY & NO \\
\hline
\end{tabular}

[RAINGAGES]

\begin{tabular}{|c|c|c|c|}
\hline ;NName & Format & Interval SCF & Source \\
\hline 5 & INTENSI & Y 0:05 & TIMESERIES 5 \\
\hline 4 & INTENSIT & Y 0:05 & TIMESERIES 4 \\
\hline
\end{tabular}

\section{[SUBCATCHMENTS]}

\begin{tabular}{|c|c|c|c|c|c|c|c|}
\hline ;;Name & Rain Gage & Outlet & Area & \%Imperv & Width & \%Slope & CurbLen SnowPack \\
\hline $\mathrm{C} 01$ & 5 & N01 & 1.38 & 73.6 & 44 & 16.9 & 0 \\
\hline $\mathrm{C} 02$ & 5 & N02 & 1.24 & 80.9 & 25 & 12.3 & 0 \\
\hline $\mathrm{C} 03$ & 5 & N03 & 1.08 & 29.2 & 84 & 27.7 & 0 \\
\hline $\mathrm{C} 04$ & 5 & N04 & 0.93 & 100 & 46 & 4.8 & 0 \\
\hline $\mathrm{C} 05$ & 5 & N05 & 1.53 & 82.8 & 38 & 7 & 0 \\
\hline $\mathrm{C} 06$ & 5 & N06 & 1.89 & 100 & 43 & 3.1 & 0 \\
\hline C07 & 5 & N07 & 1.25 & 100 & 43 & 3.9 & 0 \\
\hline $\mathrm{C} 08$ & 5 & N08 & 1.93 & 100 & 45 & 3.1 & 0 \\
\hline C09 & 5 & N09 & 1.13 & 100 & 43 & 3.8 & 0 \\
\hline $\mathrm{C} 10$ & 5 & N10 & 0.7 & 100 & 16 & 2 & 0 \\
\hline $\mathrm{C} 11$ & 5 & N11 & 0.82 & 100 & 42 & 2.6 & 0 \\
\hline C12 & 5 & $\mathrm{~N} 12$ & 1.73 & 100 & 42 & 1.1 & 0 \\
\hline $\mathrm{C} 13$ & 5 & N13 & 1 & 100 & 45 & 1.1 & 0 \\
\hline C14 & 5 & N14 & 1.53 & 100 & 40 & 0.9 & 0 \\
\hline $\mathrm{C} 15$ & 5 & N15 & 1.16 & 100 & 42 & 0.8 & 0 \\
\hline $\mathrm{C} 16$ & 5 & N16 & 1.48 & 100 & 28 & 0.7 & 0 \\
\hline C17 & 5 & N17 & 1 & 100 & 45 & 0.9 & 0 \\
\hline $\mathrm{C} 18$ & 5 & N18 & 2.52 & 100 & 27 & 0.9 & 0 \\
\hline C19 & 5 & N19 & 0.47 & 100 & 22 & 0.8 & 0 \\
\hline $\mathrm{C} 20$ & 5 & $\mathrm{~N} 20$ & 1.45 & 52.6 & 26 & 7.5 & 0 \\
\hline $\mathrm{C} 21$ & 5 & $\mathrm{~N} 21$ & 0.99 & 86.2 & 25 & 4.7 & 0 \\
\hline $\mathrm{C} 22$ & 5 & $\mathrm{~N} 22$ & 0.62 & 64.7 & 29 & 4.7 & 0 \\
\hline $\mathrm{C} 23$ & 5 & $\mathrm{~N} 23$ & 0.45 & 100 & 22 & 3.4 & 0 \\
\hline C24 & 5 & $\mathrm{~N} 24$ & 1.28 & 61.5 & 110 & 24.4 & 0 \\
\hline $\mathrm{C} 25$ & 5 & $\mathrm{~N} 25$ & 2.19 & 90.3 & 44 & 4.8 & 0 \\
\hline $\mathrm{C} 26$ & 5 & $\mathrm{~N} 26$ & 1.25 & 94.8 & 29 & 3.3 & 0 \\
\hline $\mathrm{C} 27$ & 5 & $\mathrm{~N} 27$ & 1.12 & 85.3 & 42 & 4.3 & 0 \\
\hline $\mathrm{C} 28$ & 5 & $\mathrm{~N} 28$ & 2.42 & 100 & 48 & 3.6 & 0 \\
\hline C29 & 5 & $\mathrm{~N} 29$ & 1.53 & 100 & 55 & 3.6 & 0 \\
\hline
\end{tabular}




$\begin{array}{llllllll}\mathrm{C} 30 & 5 & \mathrm{~N} 30 & 1.95 & 100 & 49 & 3.8 & 0 \\ \mathrm{C} 31 & 5 & \mathrm{~N} 31 & 2.71 & 100 & 21 & 2.2 & 0 \\ \mathrm{C} 32 & 5 & \mathrm{~N} 32 & 1.5 & 90.6 & 25 & 1.9 & 0 \\ \mathrm{C} 33 & 5 & \mathrm{~N} 33 & 3.03 & 100 & 24 & 1.1 & 0 \\ \mathrm{C} 34 & 5 & \mathrm{~N} 34 & 3.27 & 100 & 44 & 0.5 & 0 \\ \mathrm{C} 35 & 5 & \mathrm{~N} 35 & 1.21 & 90.6 & 20 & 0.7 & 0\end{array}$

[SUBAREAS]

;;Subcatchment N-Imperv N-Perv S-Imperv S-Perv PctZero RouteTo PctRouted

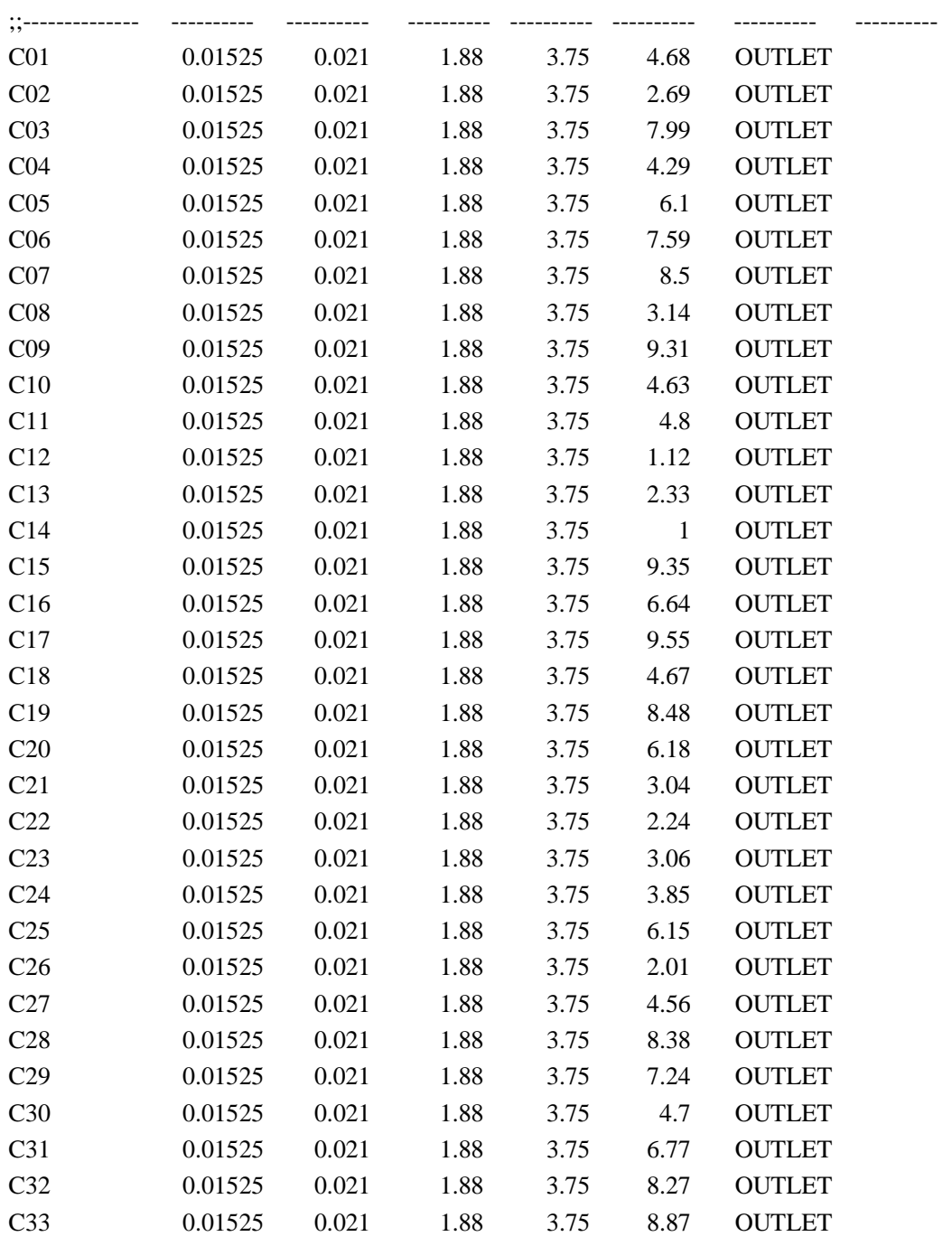




$\begin{array}{lllllll}\text { C34 } & 0.01525 & 0.021 & 1.88 & 3.75 & 1.13 & \text { OUTLET } \\ \text { C35 } & 0.01525 & 0.021 & 1.88 & 3.75 & 9.53 & \text { OUTLET }\end{array}$

[INFILTRATION]

;;Subcatchment CurveNum DryTime

;01 $\quad 80 \quad 10 \quad 7$

$\begin{array}{llll}\mathrm{C} 02 & 80 & 10 & 7\end{array}$

$\begin{array}{llll}\mathrm{C} 03 & 80 & 10 & 7\end{array}$

$\begin{array}{llll}\mathrm{C} 04 & 80 & 10 & 7\end{array}$

$\begin{array}{llll}\mathrm{C} 05 & 80 & 10 & 7\end{array}$

$\begin{array}{llll}\mathrm{C} 06 \quad 80 & 10 & 7\end{array}$

$\begin{array}{llll}\mathrm{C} 07 & 80 & 10 & 7\end{array}$

$\begin{array}{llll}\mathrm{C} 08 & 80 & 10 & 7\end{array}$

$\begin{array}{llll}\mathrm{C} 09 & 80 & 10 & 7\end{array}$

$\begin{array}{llll}\mathrm{C} 10 & 80 & 10 & 7\end{array}$

$\begin{array}{llll}\mathrm{C} 11 & 80 & 10 & 7\end{array}$

$\begin{array}{llll}\mathrm{C} 12 & 80 & 10 & 7\end{array}$

$\begin{array}{llll}\mathrm{C} 13 & 80 & 10 & 7\end{array}$

$\begin{array}{llll}\mathrm{C} 14 & 80 & 10 & 7\end{array}$

$\begin{array}{llll}\mathrm{C} 15 & 80 & 10 & 7\end{array}$

$\begin{array}{llll}\mathrm{C} 16 & 80 & 10 & 7\end{array}$

$\begin{array}{llll}\mathrm{C} 17 & 80 & 10 & 7\end{array}$

$\begin{array}{llll}\mathrm{C} 18 & 80 & 10 & 7\end{array}$

$\begin{array}{llll}\mathrm{C} 19 & 80 & 10 & 7\end{array}$

$\begin{array}{llll}\mathrm{C} 20 & 80 & 10 & 7\end{array}$

$\begin{array}{llll}\mathrm{C} 21 & 80 & 10 & 7\end{array}$

$\begin{array}{llll}\mathrm{C} 22 & 80 & 10 & 7\end{array}$

$\begin{array}{llll}\mathrm{C} 23 & 80 & 10 & 7\end{array}$

$\begin{array}{llll}\mathrm{C} 24 & 80 & 10 & 7\end{array}$

$\begin{array}{llll}\mathrm{C} 25 & 80 & 10 & 7\end{array}$

$\begin{array}{llll}\mathrm{C} 26 & 80 & 10 & 7\end{array}$

$\begin{array}{llll}\mathrm{C} 27 & 80 & 10 & 7\end{array}$

$\begin{array}{llll}\mathrm{C} 28 & 80 & 10 & 7\end{array}$

$\begin{array}{llll}\mathrm{C} 29 & 80 & 10 & 7\end{array}$

$\begin{array}{llll}\mathrm{C} 30 & 80 & 10 & 7\end{array}$

$\begin{array}{llll}\mathrm{C} 31 & 80 & 10 & 7\end{array}$

$\begin{array}{llll}\mathrm{C} 32 & 80 & 10 & 7\end{array}$

$\begin{array}{llll}\mathrm{C} 33 & 80 & 10 & 7\end{array}$

$\begin{array}{llll}\mathrm{C} 34 & 80 & 10 & 7\end{array}$

$\begin{array}{llll}\mathrm{C} 35 & 80 & 10 & 7\end{array}$


[JUNCTIONS]

;;Name Elevation MaxDepth InitDepth SurDepth Aponded

\begin{tabular}{|c|c|c|c|c|c|}
\hline N35 & 2548.43 & 3.07 & 0 & 0 & 0 \\
\hline N19 & 2552.88 & 1.38 & 0 & 0 & 0 \\
\hline N18 & 2551.24 & 2.81 & 0 & 0 & 0 \\
\hline N16 & 2553.02 & 2.29 & 0 & 0 & 0 \\
\hline N17 & 2553.31 & 2.1 & 0 & 0 & 0 \\
\hline N14 & 2553.85 & 1.97 & 0 & 0 & 0 \\
\hline N15 & 2555.04 & 1.38 & 0 & 0 & 0 \\
\hline N31 & 2556.5 & 3.49 & 0 & 0 & 0 \\
\hline N12 & 2555.55 & 2.43 & 0 & 0 & 0 \\
\hline N13 & 2555.97 & 2.74 & 0 & 0 & 0 \\
\hline N08 & 2558.57 & 2.49 & 0 & 0 & 0 \\
\hline N28 & 2561.86 & 2.63 & 0 & 0 & 0 \\
\hline N30 & 2565.41 & 1.28 & 0 & 0 & 0 \\
\hline N29 & 2569.21 & 1.53 & 0 & 0 & 0 \\
\hline N27 & 2571.38 & 2.42 & 0 & 0 & 0 \\
\hline N26 & 2571.98 & 1.48 & 0 & 0 & 0 \\
\hline N24 & 2587.65 & 2.6 & 0 & 0 & 0 \\
\hline N25 & 2568.14 & 2.26 & 0 & 0 & 0 \\
\hline N22 & 2572.07 & 1.9 & 0 & 0 & 0 \\
\hline N21 & 2570.06 & 1.57 & 0 & 0 & 0 \\
\hline N20 & 2575.59 & 1.25 & 0 & 0 & 0 \\
\hline N01 & 2585.94 & 1.4 & 0 & 0 & 0 \\
\hline N05 & 2575.26 & 2.06 & 0 & 0 & 0 \\
\hline N03 & 2573.25 & 2.25 & 0 & 0 & 0 \\
\hline N34 & 2548.97 & 3.07 & 0 & 0 & 0 \\
\hline N11 & 2556.62 & 3.35 & 0 & 0 & 0 \\
\hline N09 & 2560.66 & 1.32 & 0 & 0 & 0 \\
\hline N32 & 2559 & 0.91 & 0 & 0 & 0 \\
\hline N33 & 2553.39 & 1.94 & 0 & 0 & 0 \\
\hline N06 & 2563.08 & 1.83 & 0 & 0 & 0 \\
\hline N07 & 2563.67 & 2.45 & 0 & 0 & 0 \\
\hline N02 & 2574.53 & 2.25 & 0 & 0 & 0 \\
\hline N10 & 2556.14 & 2.19 & 0 & 0 & 0 \\
\hline N04 & 2567.97 & 1.72 & 0 & 0 & 0 \\
\hline N23 & 2564.59 & 2.61 & 0 & 0 & 0 \\
\hline
\end{tabular}




\begin{tabular}{|c|c|c|c|c|c|}
\hline \multicolumn{6}{|c|}{ [OUTFALLS] } \\
\hline ;;Name & Elevation & Type & Stage Data & Gated & Route To \\
\hline V36 & 2548.36669 & FREE & & $\mathrm{NO}$ & \\
\hline
\end{tabular}

\section{[CONDUITS]}

;Name From Node To Node Length Roughness InOffset OutOffset InitFlow MaxFlow

\begin{tabular}{|c|c|c|c|c|c|c|c|c|}
\hline P01 & N01 & N02 & 172.65 & 0.011 & 0 & 0 & 0 & 0 \\
\hline P02 & N02 & N03 & 90.99 & 0.011 & 0 & 0 & 0 & 0 \\
\hline P03 & N03 & N04 & 93.17 & 0.011 & 0 & 0 & 0 & 0 \\
\hline P04 & N04 & N06 & 187.94 & 0.011 & 0 & 0 & 0 & 0 \\
\hline P05 & N05 & N04 & 180.27 & 0.011 & 0 & 0 & 0 & 0 \\
\hline P06 & N06 & N08 & 203.82 & 0.011 & 0 & 0 & 0 & 0 \\
\hline P07 & N07 & N06 & 85.55 & 0.011 & 0 & 0 & 0 & 0 \\
\hline P08 & N08 & N10 & 113.02 & 0.011 & 0 & 0 & 0 & 0 \\
\hline P09 & N09 & N08 & 85.62 & 0.011 & 0 & 0 & 0 & 0 \\
\hline P10 & N10 & N12 & 81.8 & 0.011 & 0 & 0 & 0 & 0 \\
\hline P11 & N11 & N10 & 68.24 & 0.011 & 0 & 0 & 0 & 0 \\
\hline $\mathrm{P} 12$ & $\mathrm{~N} 12$ & N14 & 187.31 & 0.011 & 0 & 0 & 0 & 0 \\
\hline P13 & N13 & N12 & 80.08 & 0.011 & 0 & 0 & 0 & 0 \\
\hline $\mathrm{P} 14$ & N14 & N16 & 169.06 & 0.011 & 0 & 0 & 0 & 0 \\
\hline P15 & N15 & N14 & 79.98 & 0.011 & 0 & 0 & 0 & 0 \\
\hline P16 & N16 & N18 & 270.92 & 0.011 & 0 & 0 & 0 & 0 \\
\hline P17 & N17 & N16 & 84.81 & 0.011 & 0 & 0 & 0 & 0 \\
\hline P18 & N18 & N34 & 90.38 & 0.011 & 0 & 0 & 0 & 0 \\
\hline P19 & N19 & N18 & 66.74 & 0.011 & 0 & 0 & 0 & 0 \\
\hline P20 & N20 & N21 & 124.22 & 0.011 & 0 & 0 & 0 & 0 \\
\hline $\mathrm{P} 21$ & N21 & $\mathrm{N} 23$ & 79.16 & 0.011 & 0 & 0 & 0 & 0 \\
\hline $\mathrm{P} 22$ & N22 & $\mathrm{N} 21$ & 52.91 & 0.011 & 0 & 0 & 0 & 0 \\
\hline $\mathrm{P} 23$ & $\mathrm{~N} 23$ & $\mathrm{~N} 28$ & 194.54 & 0.011 & 0 & 0 & 0 & 0 \\
\hline $\mathrm{P} 24$ & N24 & $\mathrm{N} 25$ & 270.94 & 0.011 & 0 & 0 & 0 & 0 \\
\hline $\mathrm{P} 25$ & $\mathrm{~N} 25$ & $\mathrm{~N} 23$ & 85.78 & 0.011 & 0 & 0 & 0 & 0 \\
\hline P26 & N26 & $\mathrm{N} 27$ & 91.21 & 0.011 & 0 & 0 & 0 & 0 \\
\hline P27 & N27 & $\mathrm{N} 25$ & 203.14 & 0.011 & 0 & 0 & 0 & 0 \\
\hline P28 & N28 & N31 & 201.07 & 0.011 & 0 & 0 & 0 & 0 \\
\hline P29 & N29 & N30 & 180.09 & 0.011 & 0 & 0 & 0 & 0 \\
\hline P30 & N30 & N28 & 197.82 & 0.011 & 0 & 0 & 0 & 0 \\
\hline P31 & N31 & N33 & 187.12 & 0.011 & 0 & 0 & 0 & 0 \\
\hline P32 & N32 & N31 & 88.46 & 0.011 & 0 & 0 & 0 & 0 \\
\hline P33 & N33 & N18 & 273.72 & 0.011 & 0 & 0 & 0 & 0 \\
\hline P34 & N34 & N35 & 337.56 & 0.011 & 0 & 0 & 0 & 0 \\
\hline P35 & N35 & V36 & 33.19 & 0.011 & 0 & 0 & 0 & 0 \\
\hline
\end{tabular}


[XSECTIONS]

\begin{tabular}{|c|c|c|c|c|c|c|c|}
\hline ;Link & Shape & om1 & Geom2 & Geom3 & Geom4 & Barrels & Culvert \\
\hline P01 & CIRCULAR & 0.4 & 0 & 0 & 0 & 1 & \\
\hline P02 & CIRCULAR & 0.4 & 0 & 0 & 0 & 1 & \\
\hline P03 & CIRCULAR & 0.4 & 0 & 0 & 0 & 1 & \\
\hline P04 & CIRCULAR & 0.55 & 0 & 0 & 0 & 1 & \\
\hline P05 & CIRCULAR & 0.4 & 0 & 0 & 0 & 1 & \\
\hline P06 & CIRCULAR & 0.6 & 0 & 0 & 0 & 1 & \\
\hline P07 & CIRCULAR & 0.4 & 0 & 0 & 0 & 1 & \\
\hline P08 & CIRCULAR & 0.75 & 0 & 0 & 0 & 1 & \\
\hline P09 & CIRCULAR & 0.4 & 0 & 0 & 0 & 1 & \\
\hline P10 & CIRCULAR & 0.75 & 0 & 0 & 0 & 1 & \\
\hline P11 & CIRCULAR & 0.3 & 0 & 0 & 0 & 1 & \\
\hline P12 & CIRCULAR & 0.9 & 0 & 0 & 0 & 1 & \\
\hline P13 & CIRCULAR & 0.4 & 0 & 0 & 0 & 1 & \\
\hline P14 & CIRCULAR & 1.1 & 0 & 0 & 0 & 1 & \\
\hline P15 & CIRCULAR & 0.5 & 0 & 0 & 0 & 1 & \\
\hline P16 & CIRCULAR & 1.2 & 0 & 0 & 0 & 1 & \\
\hline P17 & CIRCULAR & 0.4 & 0 & 0 & 0 & 1 & \\
\hline P18 & CIRCULAR & 1.3 & 0 & 0 & 0 & 1 & \\
\hline P19 & CIRCULAR & 0.4 & 0 & 0 & 0 & 1 & \\
\hline P20 & CIRCULAR & 0.45 & 0 & 0 & 0 & 1 & \\
\hline $\mathrm{P} 21$ & CIRCULAR & 0.45 & 0 & 0 & 0 & 1 & \\
\hline $\mathrm{P} 22$ & CIRCULAR & 0.3 & 0 & 0 & 0 & 1 & \\
\hline $\mathrm{P} 23$ & CIRCULAR & 0.6 & 0 & 0 & 0 & 1 & \\
\hline P24 & CIRCULAR & 0.56 & 0 & 0 & 0 & 1 & \\
\hline $\mathrm{P} 25$ & CIRCULAR & 0.6 & 0 & 0 & 0 & 1 & \\
\hline P26 & CIRCULAR & 0.4 & 0 & 0 & 0 & 1 & \\
\hline P27 & CIRCULAR & 0.55 & 0 & 0 & 0 & 1 & \\
\hline P28 & CIRCULAR & 0.75 & 0 & 0 & 0 & 1 & \\
\hline P29 & CIRCULAR & 0.5 & 0 & 0 & 0 & 1 & \\
\hline P30 & CIRCULAR & 0.6 & 0 & 0 & 0 & 1 & \\
\hline P31 & CIRCULAR & 0.85 & 0 & 0 & 0 & 1 & \\
\hline P32 & CIRCULAR & 0.4 & 0 & 0 & 0 & 1 & \\
\hline P33 & CIRCULAR & 1 & 0 & 0 & 0 & 1 & \\
\hline P34 & CIRCULAR & 1.4 & 0 & 0 & 0 & 1 & \\
\hline P35 & CIRCULAR & 1.4 & 0 & 0 & 0 & 1 & \\
\hline
\end{tabular}




\begin{tabular}{|c|c|c|c|}
\hline \multicolumn{4}{|c|}{ [TIMESERIES] } \\
\hline ;;Name & Date & Time & Value \\
\hline 5 & & 0:00 & 16.73 \\
\hline 5 & & 0:05 & 24.4 \\
\hline 5 & & $0: 10$ & 38.78 \\
\hline 5 & & $0: 15$ & 70.61 \\
\hline 5 & & $0: 20$ & 118 \\
\hline 5 & & $0: 25$ & 118 \\
\hline 5 & & $0: 30$ & 57.48 \\
\hline 5 & & $0: 35$ & 39.12 \\
\hline 5 & & $0: 40$ & 28.3 \\
\hline 5 & & $0: 45$ & 21.39 \\
\hline 5 & & $0: 50$ & 16.73 \\
\hline ; & & & \\
\hline 4 & & 0:00 & 16.56 \\
\hline 4 & & 0:05 & 24.23 \\
\hline 4 & & $0: 10$ & 38.6 \\
\hline 4 & & $0: 15$ & 70.44 \\
\hline 4 & & $0: 20$ & 117.75 \\
\hline 4 & & $0: 25$ & 117.75 \\
\hline 4 & & $0: 30$ & 57.3 \\
\hline 4 & & $0: 35$ & 38.94 \\
\hline 4 & & $0: 40$ & 28.12 \\
\hline 4 & & $0: 45$ & 21.22 \\
\hline 4 & & $0: 50$ & 16.56 \\
\hline
\end{tabular}

[REPORT]

;;Reporting Options

SUBCATCHMENTS ALL

NODES ALL

LINKS ALL

[TAGS]

[MAP]

DIMENSIONS 1335503.1761009133 .3761337159 .4241010178 .464

Units None 
[COORDINATES]

$\begin{array}{lll}\text {; Node } & \text { X-Coord } & \text { Y-Coord } \\ \text {;---------- } & ------------- & ----------- \\ \text { N35 } & 1335611.630 & 1010130.960 \\ \text { N19 } & 1335969.250 & 1009872.800 \\ \text { N18 } & 1336000.848 & 1009935.275 \\ \text { N16 } & 1336175.241 & 1010044.454 \\ \text { N17 } & 1336125.350 & 1009972.540 \\ \text { N14 } & 1336314.670 & 1009969.820 \\ \text { N15 } & 1336277.690 & 1009898.900 \\ \text { N31 } & 1336400.830 & 1009722.850 \\ \text { N12 } & 1336480.880 & 1009883.460 \\ \text { N13 } & 1336443.970 & 1009812.390 \\ \text { N08 } & 1336653.920 & 1009793.950 \\ \text { N28 } & 1336578.730 & 1009629.100 \\ \text { N30 } & 1336487.290 & 1009453.680 \\ \text { N29 } & 1336532.980 & 1009334.410 \\ \text { N27 } & 1336618.040 & 1009282.940 \\ \text { N26 } & 1336617.590 & 1009210.880 \\ \text { N24 } & 1336856.190 & 1009226.110 \\ \text { N25 } & 1336711.680 & 1009463.210 \\ \text { N22 } & 1336798.000 & 1009450.920 \\ \text { N21 } & 1336821.630 & 1009498.260 \\ \text { N20 } & 1336850.910 & 1009408.120 \\ \text { N01 } & 1336969.520 & 1009338.540 \\ \text { N05 } & 1336919.970 & 1009452.300 \\ \text { N03 } & 1337084.140 & 1009570.190 \\ \text { N34 } & 1335910.570 & 1009974.780 \\ \text { N11 } & 1336531.760 & 1009786.680 \\ \text { N09 } & 1336614.400 & 1009718.000 \\ \text { N32 } & 1336357.770 & 1009646.930 \\ \text { N33 } & 1336234.210 & 1009807.980 \\ \text { N06 } & 1336834.650 & 1009699.720 \\ \text { N07 } & 1336795.410 & 1009623.700 \\ \text { N02 } & 1337043.370 & 1009488.840 \\ \text { N10 } & 1336553.640 & 1009846.070 \\ \text { N04 } & 1337001.430 & 1009613.090 \\ \text { N23 } & 1336751.300 & 1009539.290 \\ \text { V36 } & 1335578.460 & 1010129.910\end{array}$




\begin{tabular}{lll}
\multicolumn{3}{l}{ [VERTICES] } \\
;:Link & X-Coord & Y-Coord \\
;;----------- -------------- & -------------- \\
P01 & 1337000.440 & 1009370.580 \\
P01 & 1336995.740 & 1009402.890 \\
P01 & 1337018.460 & 1009444.020 \\
P11 & 1336558.380 & 1009840.090 \\
P16 & 1336093.870 & 1010082.640 \\
P16 & 1336079.480 & 1010081.040 \\
P16 & 1336045.650 & 1010012.490 \\
P16 & 1336005.660 & 1009936.620 \\
P19 & 1335994.690 & 1009917.650 \\
P20 & 1336850.660 & 1009412.690 \\
P20 & 1336873.430 & 1009457.250 \\
P20 & 1336867.250 & 1009474.490 \\
P21 & 1336759.810 & 1009527.970 \\
P21 & 1336754.120 & 1009537.960 \\
P24 & 1336837.940 & 1009242.420 \\
P24 & 1336726.540 & 1009455.090 \\
P26 & 1336592.610 & 1009229.600 \\
P28 & 1336467.510 & 1009685.460 \\
P29 & 1336571.560 & 1009407.330 \\
P29 & 1336568.730 & 1009413.400 \\
P31 & 1336324.080 & 1009762.680 \\
P32 & 1336388.850 & 1009705.310 \\
P32 & 1336393.720 & 1009709.470 \\
P33 & 1336115.580 & 1009871.130 \\
P34 & 1335770.010 & 1010049.670 \\
P34 & 1335740.780 & 1010063.160 \\
P34 & 1335679.740 & 1010090.470
\end{tabular}

\begin{tabular}{|c|c|c|}
\hline $\begin{array}{l}\text { [Polygons] } \\
; ; \text { Subcatchmen }\end{array}$ & nt $\mathrm{X}$-Coord & Y-Coord \\
\hline $\mathrm{C} 01$ & 336939.520 & 1009308.540 \\
\hline $\mathrm{C} 02$ & 337013.370 & 1009458.840 \\
\hline $\mathrm{C} 03$ & 337054.140 & 1009540.190 \\
\hline $\mathrm{C} 04$ & 336971.430 & 1009583.090 \\
\hline $\mathrm{C} 05$ & 1336889.970 & 1009422.300 \\
\hline C06 & 336804.650 & 1009669.720 \\
\hline $\mathrm{C} 07$ & 336765.410 & 1009593.700 \\
\hline $\mathrm{C} 08$ & 336623.920 & 1009763.950 \\
\hline $\mathrm{C} 09$ & 336584.400 & 1009688.000 \\
\hline $\mathrm{C} 10$ & 336523.640 & 1009816.070 \\
\hline
\end{tabular}




$\begin{array}{lll}\text { C11 } & 1336501.760 & 1009756.680 \\ \text { C12 } & 1336450.880 & 1009853.460 \\ \text { C13 } & 1336413.970 & 1009782.390 \\ \text { C14 } & 1336284.670 & 1009939.820 \\ \text { C15 } & 1336247.690 & 1009868.900 \\ \text { C16 } & 1336134.620 & 1010017.710 \\ \text { C17 } & 1336095.350 & 1009942.540 \\ \text { C18 } & 1335960.840 & 1009903.240 \\ \text { C19 } & 1335939.250 & 1009842.800 \\ \text { C20 } & 1336820.910 & 1009378.120 \\ \text { C21 } & 1336791.630 & 1009468.260 \\ \text { C22 } & 1336768.000 & 1009420.920 \\ \text { C23 } & 1336721.300 & 1009509.290 \\ \text { C24 } & 1336826.190 & 1009196.110 \\ \text { C25 } & 1336681.680 & 1009433.210 \\ \text { C26 } & 1336587.590 & 1009180.880 \\ \text { C27 } & 1336588.040 & 1009252.940 \\ \text { C28 } & 1336548.730 & 1009599.100 \\ \text { C29 } & 1336502.980 & 1009304.410 \\ \text { C30 } & 1336457.290 & 1009423.680 \\ \text { C31 } & 1336370.830 & 1009692.850 \\ \text { C32 } & 1336327.770 & 1009616.930 \\ \text { C33 } & 1336204.210 & 1009777.980 \\ \text { C34 } & 1335880.570 & 1009944.780 \\ \text { C35 } & 1335581.630 & 1010100.960\end{array}$

\section{[SYMBOLS]}

;;Gage X-Coord Y-Coord




\title{
Appendix IV
}

\author{
Multi-objective optimization \\ for urban drainage or Sewer \\ networks rehabilitation \\ through pipes substitution and \\ storm tanks installation
}

\section{Reference:}

Ngamalieu-Nengoue, U.A.; Martínez-Solano, F.J.; Iglesias-Rey, P.L.; Mora-Meliá, D. Multi-Objective Optimization for Urban Drainage or Sewer Networks Rehabilitation through Pipes Substitution and Storage tanks installation. Water 2019, vol. 11, no. 5, pp. 935. https://doi.org/10.3390/w11050935 


\begin{abstract}
Drainage networks are civil constructions which do not generally attract the attention of decision-makers. However, they are of crucial importance for cities; this can be seen when a city faces floods resulting in extensive and expensive damage. The increase of rain intensity due to climate change may cause deficiencies in drainage networks built for certain defined flows which are incapable of coping with sudden increases, leading to floods. This problem can be solved using different strategies; one is the adaptation of the network through rehabilitation. A way to adapt the traditional network approach consists of substituting some pipes for others with greater diameters. More recently, the installation of storm tanks makes it possible to temporarily store excess water. Either of these solutions can be expensive, and an economic analysis must be done. Recent studies have related flooding with damage costs. In this work, a novel solution combining both approaches (pipes and tanks) is studied. A multi-objective optimization algorithm based on the NSGA-II is proposed for the rehabilitation of urban drainage networks through the substitution of pipes and the installation of storage tanks. Installation costs will be offset by damage costs associated with flooding. As a result, a set of optimal solutions that can be implemented based on the objectives to be achieved by municipalities or decisions makers. The methodology is finally applied to a real network located in the city of Bogotá, Colombia.
\end{abstract}

Keywords: drainage networks; flooding; rehabilitation; multi-objective optimization; SWMM.

\title{
IV.1. Introduction
}

Over time, sewer networks present limitations in terms of carrying out the purpose to which they were assigned at the time of their construction. Unfortunately, their drainage capacity is limited to a few historic rainfall events or storms. Rainfalls with greater intensities may produce floods. For example, the total damage associated with floods in Spain between the years 1971 and 2017 reached 6 billion euros. This amount is more than $60 \%$ of the total amount of damages paid by insurance companies [1]. Flooding in urban areas has become increasingly common for different reasons. Kordana [2] categorizes the factors affecting the capacities of sewer networks as political, economic, social, technological, legal or environmental. Anthropogenic factors, linked to excessive urbanization, are partly responsible; some other reasons are related to climate change [3]. Extreme rainfalls events are important parameters affecting various natural and socio-economic systems. The evolution of rainfall also affects the efficiency of drainage networks. Starzec et al. [4] suggest that omitting the evolution of 
storms can led to undersizing the network. Mailhot and Duchesne [5] suggest that the probability of the occurrence of intense rainfall will increase in the future due to the effects of greenhouse gases. Gulizia and Camilloni [6] made a comparison among different global climate models which had been applied to South America. These models showed that an increase of up to $36 \%$ in rainfall events is expected in some regions. Ma et al. [7] studied the effects and frequency of flash floods in China. They arrived at the conclusion that flash floods are still the main cause of deaths in flood disasters. This situation is becoming alarming, since it is to be expected that urban drainage networks designed for past conditions will not function effectively in the future [8]. It should be noted that climate change is suspected as the cause of floods due to its effects on rainfall intensity and frequency.

However, not only climate change affects drainage and sewer networks performance; aging, structural collapses and exfiltration (leaking) might affect them too [5]. Moselhi et al. [9] presented a methodology based on neural networks to automatically detect and classify defects in drainage networks pipes. The aim of their methodology was to implement appropriate actions to upgrade the network.

Managers and others responsible for the operation of drainage networks must implement effective measures to ensure that infrastructure will be ready for these changes [8]. Several options are available for these managers: Real Time Control (RTC), reparation or rehabilitation. Driessen et al. [10] define five different complementary approaches to improve the resilience of hydraulic infrastructure: prevention, defense, mitigation, preparation and recovery. Among these strategies, the most traditional is flood defense, based on the idea of "keep water away from people". However, these traditional methods have shown limitations, since they cannot guarantee the cost-benefit effectiveness of the proposed solution.

Over the years, several studies on pipe replacement have been carried out to achieve optimal rehabilitations of defective sewer networks in order to prevent floods and environmental threat while minimizing investments costs. Reyna et al. [11] have proposed some solutions to the challenges which are encountered in the process of finding new strategies for sewer network rehabilitation methodologies which seek to maintain the cost-effectiveness. Abraham et al. [12] proposed an integrated management methodology considering Markovian probability-based models combined with deterministic models to predict structural failures in sewer networks. Based on these models, they proposed a priority rehabilitation plan which would reduce investment costs. The methodology first discretizes the network in small systems which are identified based on their structural characteristics. However, all these approaches become ineffective when the effects of climate change are taken into account.

Traditionally, the design of urban drainage systems is based on statistical analyses of past events. Keeping in mind that an increase in the intensity and frequency of extreme rainfall events will most probably result in more frequent flooding, Mailhot and Duchesne [5] proposed a revision of the design criteria of urban drainage 
infrastructure which takes into account uncertainties related to climate change. Gaudio et al. [1] proposed a combined methodology for the hydraulic rehabilitation of urban drainage networks. In contrast to traditional methods, they concluded that not only intensity, but also rainfall volume, influence the hydraulic design. They combined the observed rainfall data and synthetic hyetographs to deduce critical hydraulic conditions in terms of overflow volumes rather than rainfall volumes. All these studies conclude that rainfall volumes might be even more important than rainfall intensities as a design criterion.

During the last decade, a new trend in drainage network rehabilitation has been developed and implemented: the Best Management Practices (BMP). BMPs consist of reducing flooding at low cost using source controls and other devices to increase infiltration and reduce runoff. Some interesting studies have been carried out to popularize the technique. Sebti et al. [13] developed an optimization model based on Linear Programming for the optimal selection and placement of structural measures. They considered four types of structural BMPs: retention pond, green roofs, infiltration tranches and vegetated depressions. They tried to minimize the total cost of BMPs, limiting the combined sewer overflow as a constraint. Zahmatkesh et al. [14] used a global climate model (CMIP5) to generate rainfall scenarios that were used as the input for hydraulic analyses. As a result, the impact of climate change on the Bronx River watershed (New York City) was analyzed. Considering the impact of climate change on watershed runoff, the potential for Low-Impact Development (LID) controls to mitigate the effects was investigated. Stormwater runoff and LID controls were modeled using the Storm Water Management Model (SWMM) [15]. The results obtained by Mora et al. [16] showed that green roofs are efficient for small to moderate rainfalls, but that their implementation could prevent the flooding due to extreme rainfall events.

As stated by Driessen et al. [10], any strategy which seeks to reduce floods has some costs. Ugarelli and Di Federico [17] presented a cost-based methodology for drainage networks service level upgrading. This approach unifies both upgrading actions and damage costs, that is, costs associated with the risk of failure. A comparison between maintenance costs, renovation costs and rehabilitation costs was first performed in order to select the optimal course of action taking into account economical and engineering factors. Ngamalieu-Nengoue et al. [18] performed an analysis of costs related to pipe renewal and the installation of detention storm tank. They presented an optimization methodology to obtain the best solutions for drainage network rehabilitation linking SWMM as the hydraulic solver and Genetic Algorithm as the optimization model. The methodology makes it possible to define the pipes that should be changed and the places in which detention tanks should be installed. In this process, floods were considered unacceptable, and solutions had to ensure that no such event could occur.

Floods produce damages, and these damages have costs. Exact flood damage costs cannot be known until the capacity of the drainage network is exceeded. However, several studies have shown that flood damage costs depend on the area where flooding occurs and on the depth of the water. Lee and Kim [19] demonstrated that flooding volume in urban areas was not linearly proportional to flooding damage. There are two 
ways to represent flood cost damages [20]: (i) proportional to the flood volume at nodes, and (ii) proportional to the level of flooding. In the latter case, the flooding area in each node must be defined. The study concluded that flooding costs are a function of the water level reached. Both approaches were confirmed by Lee and Kim [19], who pointed out that flooding damage is different from flooding volume, because each subarea has different components.

Facing this growing risk, urban drainage management is moving towards a flood risk management approach related to city resilience, that is, the capacity to continue functioning even under hazardous conditions. Fadel et al. [21] presented a risk-based method for introducing protection measures. The standard approach uses comparisons of damage costs with and without measures as a decision-making tool. These authors include the concept of risk with an associated probability. They applied this methodology to different rainfall scenarios ranging from 2 to 200 years of return period, and to three protection scenarios: no measure, land zoning and levee. The results showed that land zoning, i.e., an adaptation measure was a better solution than levees i.e., a structural measure. They concluded their study by recommending the use of flood costs for their risk assessment, as it proved its cost-effectivity.

Due to their unpredictable nature, flood damage costs cannot be harmonized with construction costs. Investments on sewer network adaptation are made, but damages associated with floods depend on the probability of their occurrence. These costs are different in nature, and a multi objective optimization algorithm is advisable to establish a relationship between both functions.

The incorporation of detention tanks in drainage networks might be considered as a form of implementation of BMP. This practice is becoming popular and is being implemented in the design of sewer networks to avoid floods and the contamination of receiving water bodies. The use of detention tanks has increased over the last decade [22]. Detention tank volumes are calculated depending of rainfall levels. Starzec [23] proposed a method to determine the required volume of these devices as a function of the time to the maximum flow, instead of using rainfall duration. Pochwat and Słys [24] proposed the use of artificial neural networks as a tool for the estimation of the duration of rainfall events. Other authors $[18,25]$ use heuristic methods to determine the optimal size of detention tanks.

At first, in-line detention tanks were used to control pollution in both storm and waste water networks. De Martino et al. [26] compared three different configurations of these tanks using efficiency in pollutant removal as ranking criteria. Andrés-Doménech et al. [27] studied the resilience of storm water detention tank efficiency levels with respect to changes in rainfall forcing. Wang et al. [28] proposed a rehabilitation methodology connecting SWMM to a multi-objective framework to find optimal locations for storage tank installation, thereby showing that storage tanks reduce not only TSS, but also flooding. Cunha et al. [29] showed that the location, dimensions and flow control capabilities of storage tanks strongly affect their efficiency. In the work of Cunha 
et al., only storage tanks were implemented as a strategy for flood reduction; Simulated Annealing was used as the optimization model. As an alternative solution, Dziopak [30] or Słyś [31] proposed the use of control devices, allowing storage in the channel themselves.

Hence, in previous works, some actions were taken and optimized to eliminate the effects of floods. Concretely, Cunha et al. [29] used orifices as a hydraulic control in storage tanks, while Iglesias-Rey [32] combined storage tanks with increasing sewer transport capacities. Both works were done using evolutionary algorithms with a single objective optimization model. In this paper, a novel multi-objective approach combining not only pipe renewal but also storm tank size and location is developed. Furthermore, the model takes into account the economic effects of floods. Consequently, this paper is a worthwhile contribution because, as discussed previously, no previously published works have combined these three items.

Since the damage associated with flooding depends on the probability of rainfall, a multi-objective approach is assumed. Two different cost functions will be defined: investment costs for pipes and tanks, and damage costs associated with the flood itself. A multi-objective optimization algorithm was built linking an adapted Nondominated Sorting Genetic Algorithm (NSGA-II) [33] with a SWMM programmer toolkit [34] to perform the rehabilitation of drainage networks by combining the use of pipe substitutions and the installation of storage tanks. Flooding damages are quantified in term of money based on the water level of the flood. As a result, a set of Pareto fronts were obtained relating both types of costs. These solutions can be used by network managers to make decisions concerning the rehabilitation plans and investments within the context of budget limitations.

Finally, as a case study, this methodology will be applied to the E-Chicó area of Bogotá, Colombia.

\section{IV.2. Methodology}

\section{IV.2.1. Problem Formulation}

Urban drainage systems are designed to cope with predicted storms. When these systems experience extreme rainfall, the excess of water accumulates out of the network and floods occur. Flooding may cause important damage in cities, and this damage can be converted into cost. Hence, floods may be represented as a damage function. Several corrective actions might be taken to avoid flooding. Among them, increasing the size of pipes or installing retention tanks stand out as obvious choices. These actions imply an investment and have associated costs. The problem consists of harmonizing the installation costs of these corrective actions with the damage costs which would arise as a consequence of flooding.

The relationship between both types of costs presents two aspects. On the one hand, there is a hydraulic connection. Investments imply increasing transport capacity of 
the network and, consequently, reducing floods. On the other hand, flood damage costs depend on extreme rainfall probability. In other words, investments are made based on the probability of a storm occurring, while damage may occur with some level of probability.

To relate both concepts, a mathematical model of the drainage system was combined with a multi-objective optimization algorithm. Let a solution be a set of corrective actions adopted for the network. For every proposed solution, the hydraulic solver calculates the behavior of the network, focusing on the presence of flood. Then, the level of fit is calculated with both installation costs and flood damage. Finally, the optimization algorithm ranks every feasible solution to produce the next generation of solutions until the termination criterion is reached. Coupling between the optimization algorithm and the hydraulic model was achieved using a connection library, as described in [34]. An outline of the process is shown in Figure 1.

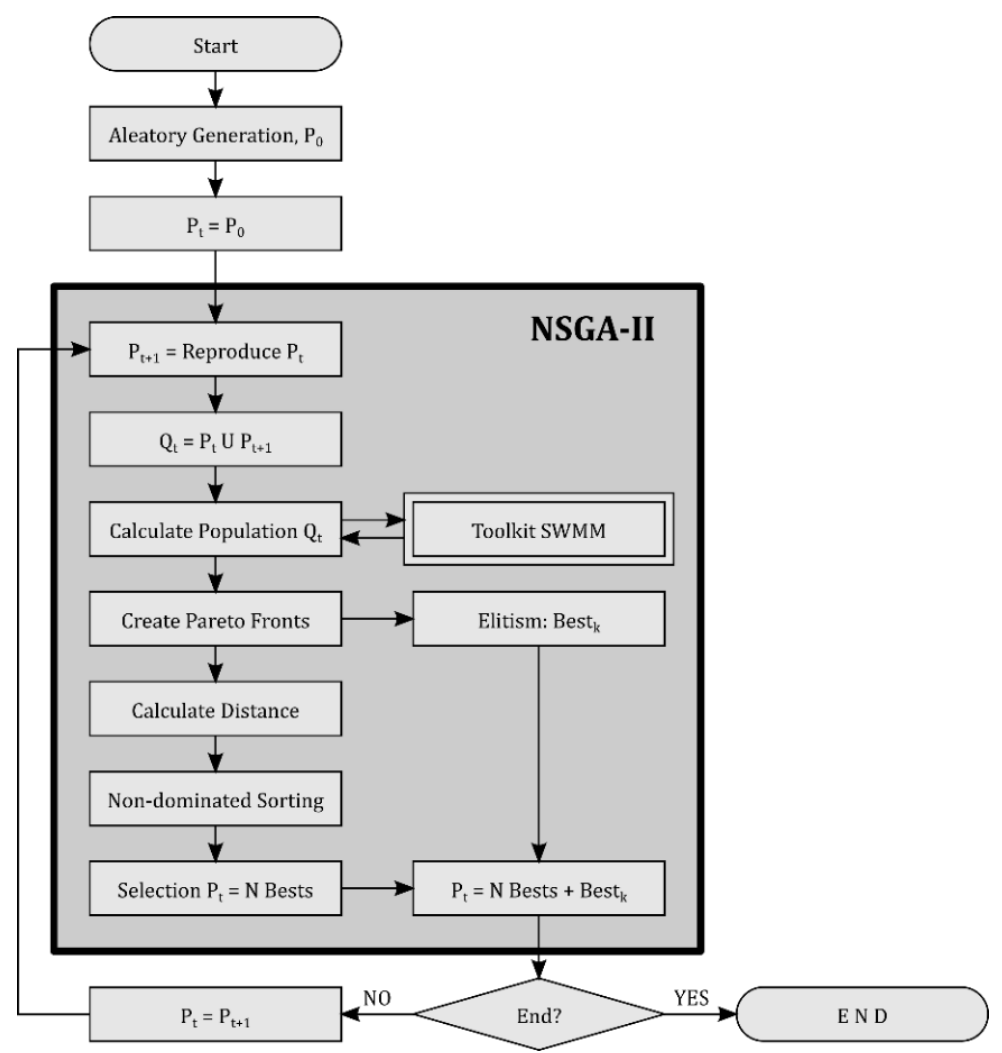

Figure 1. Flow chart of NSGA II performed in the methodology. 
The methodology assumes the following hypotheses:

- The design storm is supposed to be static and the same for the whole network. Some authors [4] state that static rainfall may produce undersized detention tanks. The design storm and its evolution are beyond the scope of this work.

- The hydraulic model will consider that the network receives water flow directly into the different nodes. Therefore, the rainfall-runoff transformation model is performed independently.

- SWMM [15] will be used as analysis tool. A calibrated mathematical model of the drainage network is used to provide a precise view of the operation scenario.

- The mathematical model of the network should be simplified to reduce the computational time.

- The corrective actions are the installation of storage tanks and the change in pipe diameter. The unknown variables are the volume of these tanks and the new diameter of the pipes.

- The detention tanks are considered to be single chamber, in-line tanks without control devices. The invert elevation of the tanks is assumed to be the same as that of the node in which they will be installed.

- The optimization problem will be addressed in term of costs. So, cost functions for both investment and damage must be defined. However, damage is associated with a probability and investment is not, i.e., both functions are treated separately.

- The decision variables are nodes potentially becoming storage tanks and conduits where dimensions may be changed.

\section{IV.2.2. Objective Functions}

The optimization process is based on the minimization of an objective function. In this case, two objectives are in conflict in the proposed objective function, i.e., on the one hand, the investment costs and, on the other, the flood damages costs. More investments reduce flood damage costs and vice versa.

The investments costs $\left(F_{1}\right)$ include the renewal of pipes and the installation of tanks. Damage function $\left(F_{2}\right)$ relates flooding with the costs associated with it. Both functions express hydraulic variables values in monetary units and were presented in detail in [20]. These functions are expressed by Equations (1) and (2):

$$
\begin{gathered}
F_{1}=\sum_{i=1}^{N_{C}} C_{C}\left(D_{i}\right) \times L_{i}+\sum_{j=1}^{N_{T}} C_{T}\left(V_{j}\right) \\
F_{2}=\sum_{k=1}^{N_{N}} C_{I}\left(y_{k}\right) \times A_{k}
\end{gathered}
$$


In Equations (1) and (2), $N_{C}$ represents the total number of conduits in the network, $N_{N}$ represents the total number of nodes in the network and $N_{T}$ represents the total number of storage tanks installed in the network.

The cost of pipe substitution, $C_{C}\left(D_{i}\right)$, was obtained from real data supplied by pipe manufacturers. With these data, a mathematical formulation was carried out to express economically the cost of pipe substitution in euros per meter, depending on the diameter of the pipe to be installed:

$$
C_{C}\left(D_{i}\right)=A \times D_{i}+B \times D_{i}^{2}
$$

The cost of storage tank installation, $C_{T}\left(V_{j}\right)$, is associated with the storage volume of a tank $\left(V_{j}\right)$ that may be necessary to install on one node location of the network to absorb the excess water that cannot be evacuated normally through the drainage network. This function is composed of a fix term which represents the minimum costs associated with the construction $\left(C_{\text {min }}\right)$ and a variable term which depends on the total volume through a constant $\left(C_{\text {var }}\right)$ and an exponent $(n)$ :

$$
C_{T}\left(V_{j}\right)=C_{\min }+C_{v a r} \times V_{j}^{n}
$$

The flood damage cost function represents damages caused by the flooding. Some authors consider flooding as a volume ([35]); however, others present flooding as the highest depth reached by the water (y) out of the network. Lee and Kim [19] showed that flood damage is different from flood volume. They proposed a resilience index based on flood damage because some subareas are immediately damaged by a certain amount of flooding, while others are not. They represented flood damage costs as a function of the depth reached by water. Following their example, the damage function was expressed as a function of the depth $y$ of the flooding:

$$
C_{I}\left(y_{k}\right)=C_{\max } \times\left(1-e^{-k \times \frac{y_{k}}{y_{\max }}}\right)^{2}
$$

In Equation (5), $C_{\max }$ represents the maximum cost per square meter that a flood might cause. For a certain depth $\left(\mathrm{y}_{\max }\right)$, the damage is considered as irreparable; therefore, the function stops growing and the cost will reach the maximum value. Coefficient $k$ is based on historical data of damages caused by flooding.

\section{IV.2.3. Optimization Algorithm}

In the problem presented above, the two objective functions are in conflict with each other, that is, improvement of one may worsen the other. A solution is dominated if another solution improves all its objective functions. A solution is non-dominated if no other solution dominates it. A set of all non-dominated solutions is called a Pareto front. The Pareto front might be formed by an infinite number of non-dominated solutions. In this case, the NSGA-II algorithm will be used. 
NSGA-II was first introduced by Deb et al. [33]. This method adopts a fast nondominated sorting approach to rank solutions through an implicit elitist selection method based on the concepts of Pareto dominance and crowding distance. If all solutions in a Pareto front are sorted according to the different objectives, the crowding distance of a solution for an objective is the average distance of its two neighboring solutions, as shown in Figure 2. Every objective has its own crowding distance which is a solution that may be computed by combining the entire individual crowding distance values in each objective function [36]. The crowding distance value of a solution is an estimate of the density of solutions surrounding that solution.

Additionally, an additional elitism aspect was added for this work. For every generation, the best individual in every objective was selected for the next generation. That is, according to Figure 2, individuals $P_{1}$ and $P_{N}$ were selected for the next generation. Usually, the stopping criterion for multi-objective algorithms is the number of simulations or generations. In this case, the evolution of the best values for every objective was also used as stopping criterion. If, after a certain number of generations, none of the values of the objectives $\left(F_{2}\left(P_{1}\right)\right.$ and $\left.F_{1}\left(P_{N}\right)\right)$ are improved, then the algorithm stops. Another measure for assessing the algorithm was the evolution of the crowding distance. It is desirable that solutions in a Pareto front be equally distributed. In this sense, the standard deviation of the crowded distance in the first Pareto front was also taken as a measure of the quality of the front. The smaller the standard deviation, the better the solution.

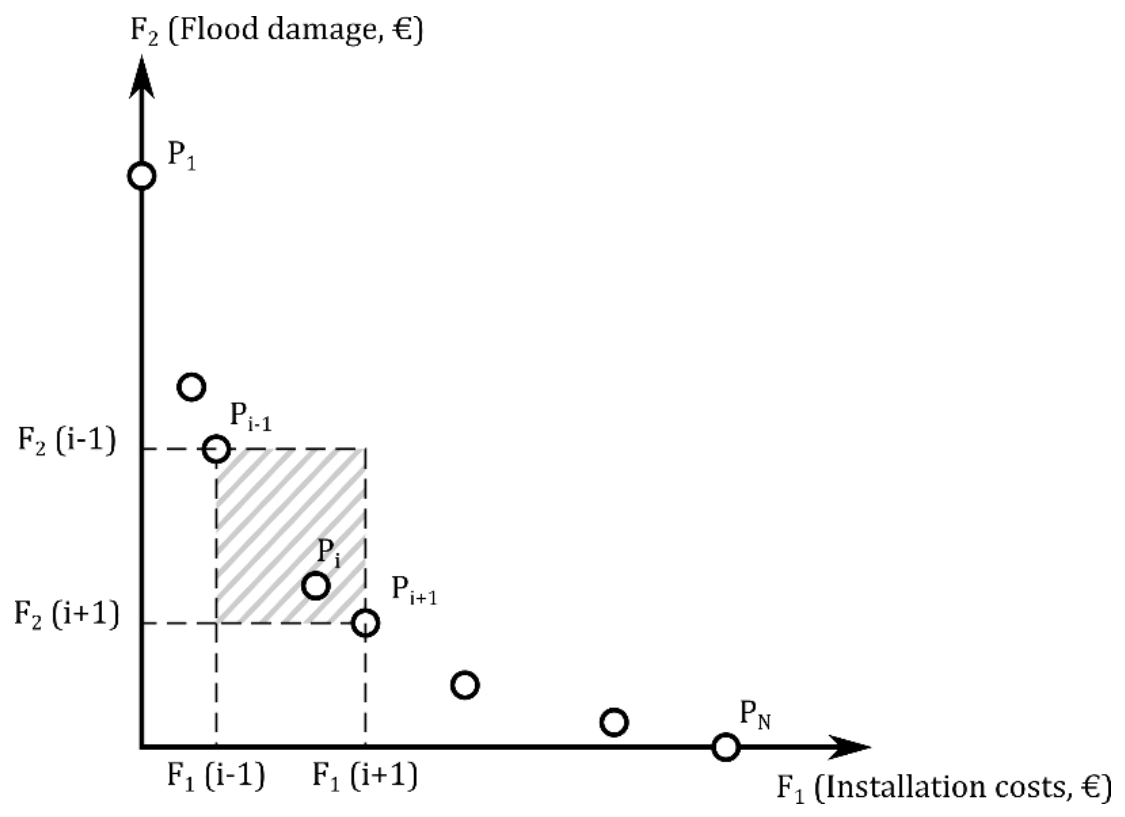

Figure 2. Main features of a Pareto front. 


\section{IV.3. Case Study}

In order to test the methodology mentioned above, a sub-catchment of the drainage network of Bogotá city, Colombia, was used. The proposed algorithm was applied to the rehabilitation of drainage or sewer networks through the substitution of pipes and the installation of storage tanks. The part of the drainage network studied is generically known as E-Chicó district. E-Chicó is divided into 35 hydrological subcatchments expanded over a surface of 51 ha. The network is composed of 35 circular conduits with diameters varying from 300 to $1400 \mathrm{~mm}$, and 35 connecting nodes. The total length of the network is around $5000 \mathrm{~m}$. The network works completely by gravity, since the terrain profile is favorable to the drainage of rainwater. The height difference between the highest and the lowest points is $39.28 \mathrm{~m}$. Figure 3 shows the E-Chicó drainage network.

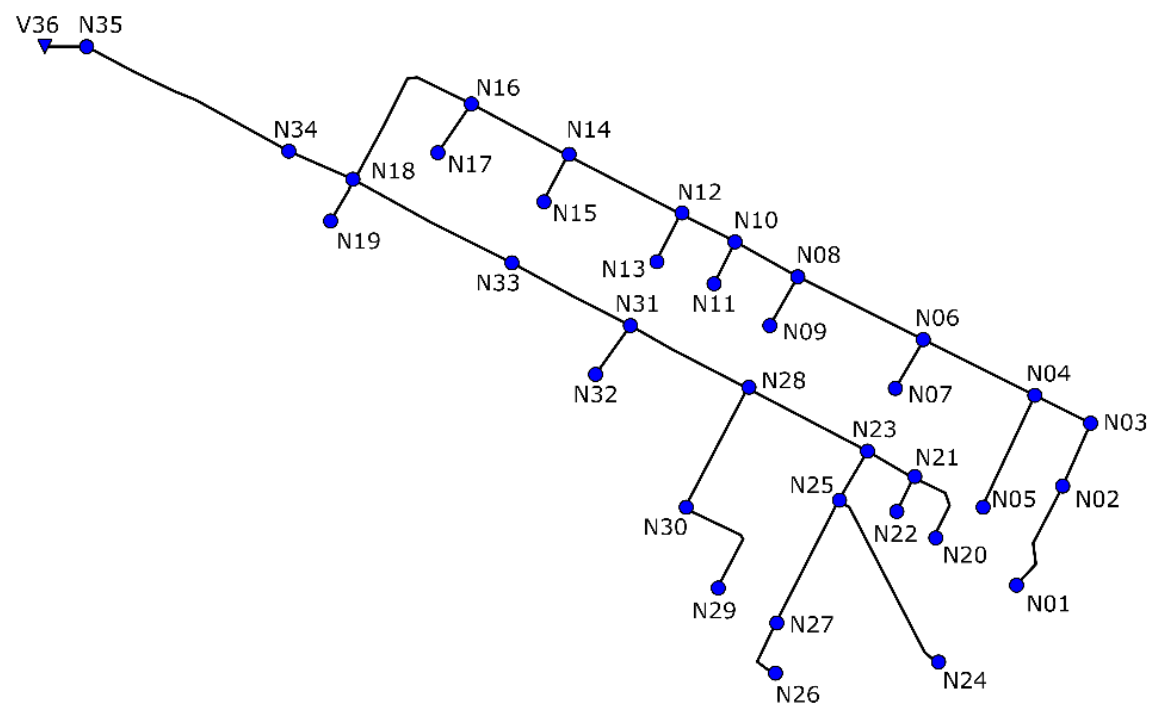

Figure 3. Representation of E-Chicó drainage network.

For diagnostic and further evaluation of possible solutions, a design storm was used based on the IDF curve for a return period of ten years. The IDF curve was obtained after the application of a climate change scenario [6]. Then, a design storm was 
calculated using the alternating block method with a time interval of 5 min and a minimum duration of $10 \mathrm{~min}$. Both, the IDF curve (left) and the design storm (right) are presented in Figure 4.
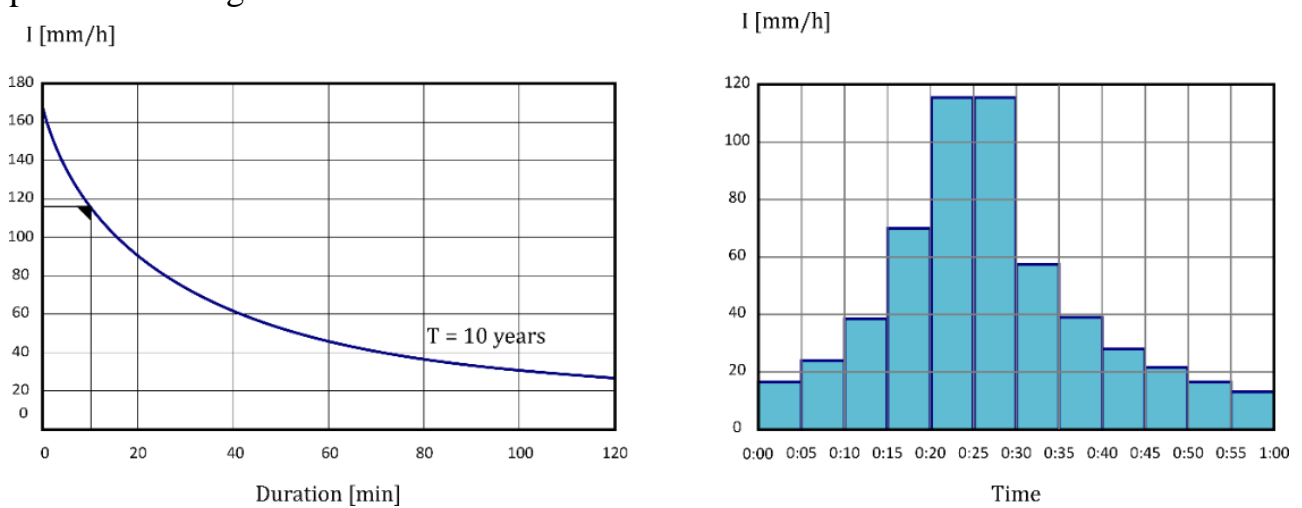

Figure 4. Rainfall used in the case study (Left: IDF curve for a return period of 10 years, Right: design storm).

The cost functions used for the case study were based on real data, according to Ngamalieu-Nengoue et al. [18]. Equations 3-5 will become, respectively:

$$
\begin{gathered}
C_{C}\left(D_{i}\right)=40.69 \times D_{i}+208.06 \times D_{i}^{2} \\
C_{T}\left(V_{j}\right)=16923+318.4 \times V_{j}^{0.65} \\
C_{I}\left(y_{k}\right)=1268 \times\left(1-e^{-4.89 \times \frac{y_{k}}{1.4}}\right)^{2}
\end{gathered}
$$

A first simulation provided the behavior of the network without any intervention. In this preliminary analysis, the network presented a flooding total volume of $3832 \mathrm{~m}^{3}$, which represents $17.6 \%$ of the generated runoff $\left(21766 \mathrm{~m}^{3}\right)$. Using the damage function described in Equation 5, it was calculated that this flood would cost 5.24 million euros. Furthermore, more than $30 \%$ of the nodes showed flooding (11 out of 35 nodes). In summary, the preliminary analysis of the network shows that it is unable to drain the selected project rain. Therefore, the E-Chicó drainage network was considered adequate as a model to which the multi-objective optimization NSGA-II rehabilitation drainage networks could be applied.

Three different rehabilitation scenarios were performed depending on the selection of the decision variables:

- Scenario 1 (35C). All the conduits were selected as suitable for rehabilitation.

- Scenario $2(35 \mathrm{~T})$. All the nodes were selected as possible locations for the installation of storage tanks. 
- Scenario $3(35 \mathrm{C}+35 \mathrm{~T})$. A combination of Scenarios 1 and 2. All the conduits and all the nodes were selected as decision variables.

For all 3 scenarios, the crossover probability was fixed at $80 \%$, while the mutation coefficients were calculated as the inverse of the number of decision variables, as suggested by [37].

\section{IV.4. Results}

For every scenario, 10 different population sizes and six different values for the number of iterations were used. Apart from the results of the solutions in the Pareto fronts, some other indexes were gathered to assess the algorithm. The simulation time varied from 1-15 days, depending on the scenario and the selection of the parameters. For example, the rehabilitation of the whole network, corresponding to the Scenario 3 $(35 \mathrm{~T}+35 \mathrm{C})$ with a population size of 1000 individuals and a maximum number of generations 15,000 , provided results after 15 days. Next, the results of these simulations are presented.

Figure 5 represents the results obtained for the 3 different scenarios presented above, that is, the substitution of pipes $(35 \mathrm{C})$, the installation of storage tanks in some locations (35T), and the combination of both alternatives (pipes substitution and storage tanks installation, $35 \mathrm{~T}+35 \mathrm{C}$ ). These simulations were performed with a population size of 200 individuals and number of generations of 10,000 for all scenarios. Figure 5 also shows that Scenario 3 presents better results than Scenarios 1 and 2; even though this combined scenario represents a bigger problem (70 decision variables versus 35 of Scenarios 1 and 2), the combination of the two different strategies led to better results.

The NSGA-II presents a set of feasible solutions instead of a single one. This way, the decision about the best solution depends on several factors, i.e., budget availability, risk level, administrative regulations, etc. This is the reason why the multiobjective algorithm was selected. As an example, the solution for the case of unlimited budget availability is presented. If there are no investment limitations, the solution will look for a scenario with no flooding. This scenario corresponds to the horizontal axis of Figure 5. The solution for zero flooding needs an investment of either 1,213,453€ in pipe renewal or $719,366 €$ in storage units. In accordance with the methodology presented in this paper, the problem can be solved with a joint investment of $517,559 €$. Solutions in terms of the volume of detention tanks and the diameters of pipes are shown in Figure 6. Pipes marked with dashed lines represent changed pipes with respect to the original network.

The solution to Scenario 3 shows that pipes connected to downwards tanks have a reduced diameter, meaning that those pipes act as a hydraulic control device. This confirms what was stated by Starzec et al. [4], and opens up the possibility of including hydraulic controls in the optimization process. 


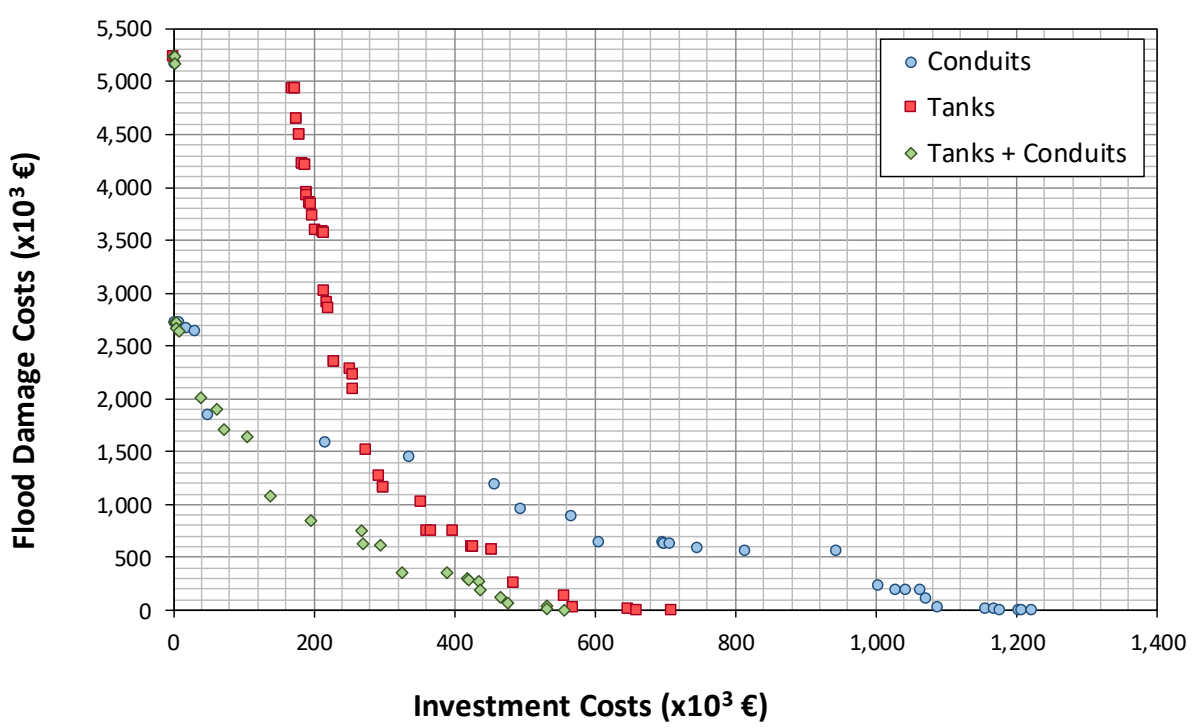

Figure 5. Pareto front representation of 3 different scenarios.
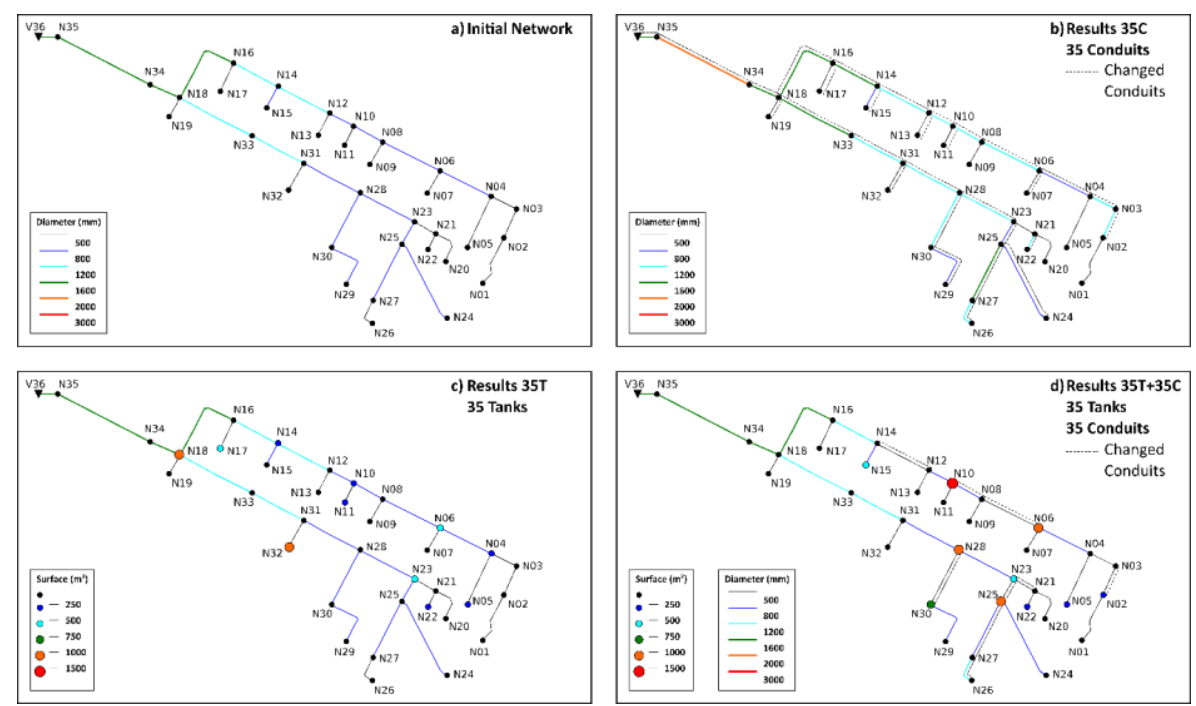

Figure 6. Original network (a) and solutions for no flooding for Scenarios 1 (b), 2 (c) and $3(\boldsymbol{d})$. Changed pipes are represented as dashed lines. 
In this figure, all scenarios provide the same damage costs for no investment. This is due to a slight modification in the algorithm. The initial population was not entirely random, since two additional individuals were added: the zero-investment and the maximum investment (which causes zero flood damage cost) solutions. The zeroinvestment solution cannot be improved, and hence, is present in every solution. In contrast, the maximum investment cost was simulated assuming that all the pipes were renewed using the maximum available diameter (2000 $\mathrm{mm}$ for this case) and that the tanks would have the maximum area. This solution might be improved during the simulation. As an example, Figure 7 shows the evolution of this zero-damage solution as the simulation progresses under two different simulations. It can be observed that the solution for zero flooding quickly become unchanged (after 20 to 50 generations). A stopping criterion based on the evolution of this parameter was tested, but the results suggested that this stopping criterion could be discarded.

Investment Costs $(€)$

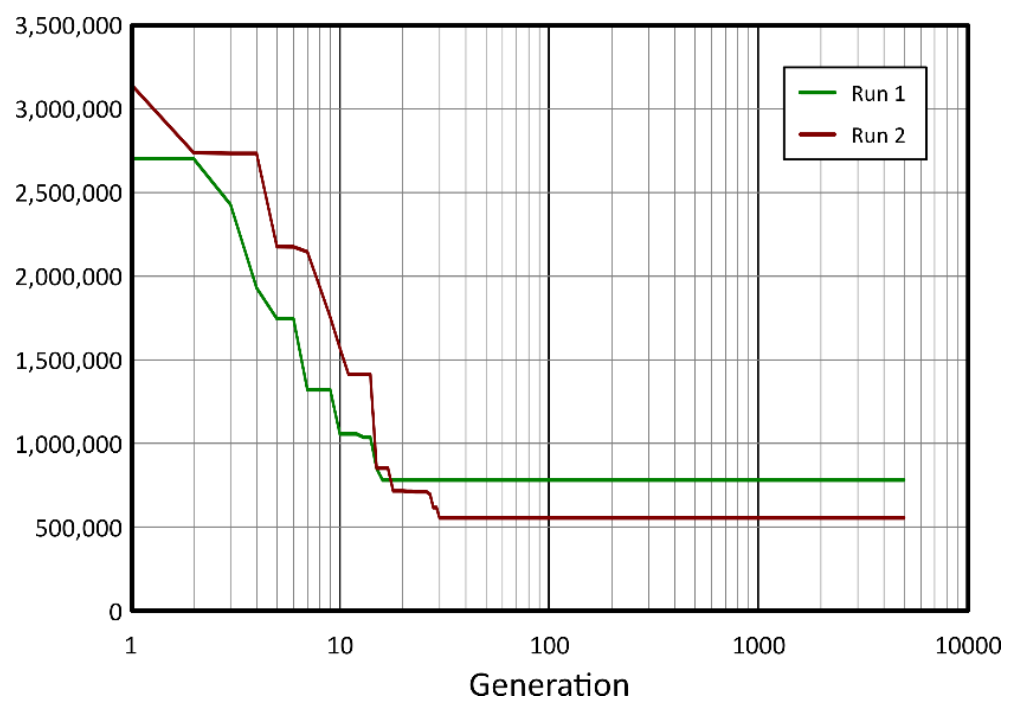

Figure 7. Evolution of the minimal investment costs for a no-flooding situation as a function of the generation. The scenario used corresponds to combining tanks and pipes $(35 T+35 C)$ under two different simulations.

Another indicator used to evaluate the solution was the standard deviation of the crowding distance in the first Pareto front. The dependence of this parameter with the population size was also studied. Figure 8 shows that there is a strong dependency between both parameters. In fact, this figure shows that this relation might be represented by a power function with an extremely high correlation. This relation makes it possible 
to determine the minimum population for a desired distribution of individuals in the Pareto front.

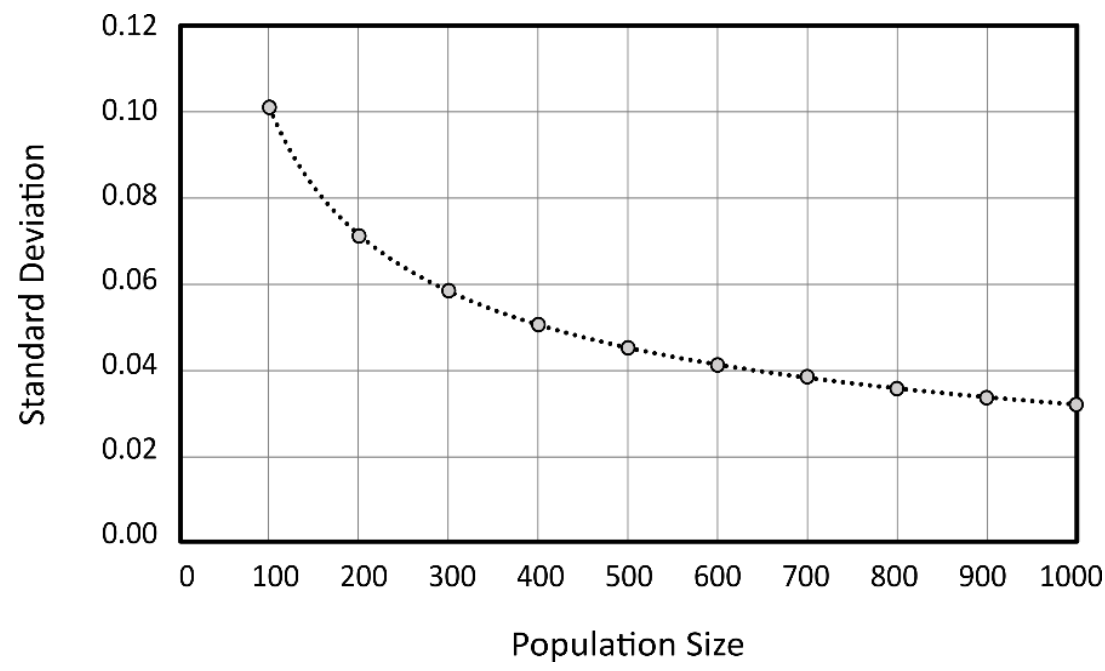

Figure 8. Standard deviation of first Pareto front as a function of population size in the final solution for Scenario $3(35 T+35 C)$.

Finally, some other relationships were studied. As expected, the evolution of the minimal investment costs to eliminate floods with a given population size concludes that the results are better when the number of generations increases. This conclusion was also reached by other researchers [38].

\section{IV.5. Conclusions}

A multi-objective optimization algorithm based on NSGA-II for drainage network rehabilitation has been presented as a tool to help managers of drainage networks, or any other decision makers, to establish rehabilitation plans of their networks. Budget limitations are considered, and a set of solutions is provided, as opposed to just one, allowing decisions to be made based upon the objectives to be achieved and the available budget. The tool was tested on the network of E-Chico (Colombia) and the results obtained are in accordance with those of some previous studies. An EPA-SWMM hydraulic engine was used as the solver for the hydraulic conditions of the network.

The first conclusion obtained after this work was that the combined use of pipe rehabilitation and detention tanks improved the performance of the network in comparison to any strategy used separately. 
The use of damage functions to evaluate the effect of flooding makes it possible to compare investment and damages, even though the first comprises expenses that depend on the probability of the occurrence of rainfall.

The capacity of the optimization tool to provide better results was also tested, and it stands out that, depending on the rehabilitation configuration, the population size must be large (greater than 500 individuals). Even though this conclusion was expected, the use of a medium population size was enough to achieve acceptable solutions in some cases. The computational effort needed to solve the case study indicates that some additional studies must be done which seek to reduce the size of the problem.

Different stopping criteria were used. The total number of generations or an objective value in the standard deviation of the crowding distance in the first Pareto front showed better performance than the evolution of the investment cost needed to avoid flooding.

The main conclusion of this paper is that the combination of the renewal of pipes and the installation of storage units can reduce the risk for sewer network utilities vis-àvis eventual rainfall increases due to climate change. The results for the combined solution show that some of the conduits are substituted for smaller ones. This fact implies some type of flow control based on hydraulic principles.

The results obtained in the Pareto front consist of a set of feasible solutions that will help decision makers select the best option. However, there is no optimal solution; any model must be chosen in accordance with some criteria or rules, i.e., budget availability, risk evaluation, design criteria, etc.

The results of this paper open up a wide field for future investigation, including working with three different scenarios (separating investment costs on tanks from investments on pipe rehabilitation). On the one hand, the combination of tanks and pipes which conform with a hydraulic control device for flooding is a topic that should be studied. On the other, flood analysis requires great computational effort. In this sense, additional research must be done to reduce the size of the problem.

\section{IV.6. References}

1. Consorcio de Compensación de Seguros. Estadística Riesgos Extraordinarios; Serie 1971-2017; Ministerio de Economía y Empresa: Madrid, Spain, 2016. (In Spanish)

2. Kordana, S. The identification of key factors determining the sustainability of stormwater systems. E3S Web Conf. 2018, 45, 00033.

3. Yazdi, J.; Lee, E.H.; Kim, J.H. Stochastic multiobjective optimization model for urban drainage network rehabilitation. J. Water Resour. Plan. Manag. 2015, 141, 04014091.

4. Starzec, M.; Dziopak, J.; Sły's, D.; Pochwat, K.; Kordana, S. Dimensioning of required volumes of interconnected detention tanks taking into account the direction and speed of rain movement. Water 2018, 10, 1826. 
5. Mailhot, A.; Duchesne, S. Design criteria of urban drainage infrastructures under climate change. J. Water Resour. Plan. Manag. 2010, 136, 201-208.

6. Gulizia, C.; Camilloni, I. Comparative analysis of the ability of a set of CMIP3 and CMIP5 global climate models to represent precipitation in South America. Int. J. Climatol. 2015, 35, 583-595.

7. Ma, M.; He, B.; Wan, J.; Jia, P.; Guo, X.; Gao, L.; Maguire, L.; Hong, Y. Characterizing the flash flooding risks from 2011 to 2016 over China. Water 2018, 10,704 .

8. Kirshen, P.; Caputo, L.; Vogel, R.M.; Mathisen, P.; Rosner, A.; Renaud, T. Adapting urban infrastructure to climate change: A drainage case study. J. Water Resour. Plan. Manag. 2015, 141, 04014064.

9. Moselhi, O.; Shehab-Eldeen, T. Classification of defects in sewer pipes using neural networks. J. Infrastruct. Syst. 2000, 6, 97-104.

10. Driessen, P.; Hegger, D.; Kundzewicz, Z.; van Rijswick, H.; Crabbé, A.; Larrue, C.; Matczak, P.; Pettersson, M.; Priest, S.; Suykens, C.; et al. Governance strategies for improving flood resilience in the face of climate change. Water 2018, 10, 1595.

11. Reyna, S.M.; Vanegas, J.A.; Khan, A.H. Construction Technologies for Sewer Rehabilitation. J. Constr. Eng. Manag. 1994, 120, 467-487.

12. Abraham, D.M.;Wirahadikusumah, R.; Short, T.J.; Shahbahrami, S. Optimization modeling for sewer network management. J. Constr. Eng. Manag. 1998, 124, 402410.

13. Sebti, A.; Fuamba, M.; Bennis, S. Optimization model for BMP selection and placement in a combined sewer. J. Water Resour. Plan. Manag. 2015, 142, 04015068.

14. Zahmatkesh, Z.; Burian, S.J.; Karamouz, M.; Tavakol-Davani, H.; Goharian, E. Low-impact development practices to mitigate climate change effects on urban stormwater runoff: Case study of New York City. J. Irrig. Drain. Eng. 2015, 141, 04014043.

15. Rossman, L.A. StormWater Management Model User's Manual; National Risk Management Research Laboratory: Cincinnati, OH, USA, 2015.

16. Mora-Melià, D.; López-Aburto, C.; Ballesteros-Pérez, P.; Muñoz-Velasco, P. Viability of green roofs as a flood mitigation element in the central region of Chile. Sustainability 2018, 10, 1130.

17. Ugarelli, R.; Di Federico, V. Optimal scheduling of replacement and rehabilitation in wastewater pipeline networks. J. Water Resour. Plan. Manag. 2010, 136, 348356.

18. Ngamalieu-Nengoue, U.; Iglesias-Rey, P.; Martínez-Solano, F.; Mora-Meliá, D.; Saldarriaga Valderrama, J. Urban drainage network rehabilitation considering storm tank installation and pipe substitution. Water 2019, 11, 515.

19. Lee, E.; Kim, J. Development of resilience index based on flooding damage in urban areas. Water 2017, 9, 428. 
20. Iglesias-Rey, P.L.; Martínez-Solano, F.J.; Saldarriaga, J.G.; Navarro-Planas, V.R. Pseudo-genetic model optimization for rehabilitation of urban storm-water drainage networks. Procedia Eng. 2017, 186, 617-625.

21. Fadel, A.W.; Marques, G.F.; Goldenfum, J.A.; Medellín-Azuara, J.; Tilmant, A. Full flood cost: Insights from a risk analysis perspective. J. Environ. Eng. 2018, 144, 04018071.

22. Duan, H.-F.; Li, F.; Yan, H. multi-objective optimal design of detention tanks in the urban stormwater drainage system: LID implementation and analysis. Water Resour. Manag. 2016, 30, 4635-4648.

23. Starzec, M. A critical evaluation of the methods for the determination of required volumes for detention tank. E3S Web Conf. 2018, 45, 00088.

24. Pochwat, K.B.; Sły's, D. Application of artificial neural networks in the dimensioning of retention reservoirs. Ecol. Chem. Eng. S 2018, 25, 605-617.

25. Cunha, M.C.; Zeferino, J.A.; Simões, N.E.; Saldarriaga, J.G. Optimal location and sizing of storage units in a drainage system. Environ. Model. Softw. 2016, 83, 155166.

26. De Martino, G.; De Paola, F.; Fontana, N.; Marini, G.; Ranucci, A. Pollution reduction in receivers: Storm-water tanks. J. Urban Plan. Dev. 2011, 137, 29-38.

27. Andrés-Doménech, I.; Montanari, A.; Marco, J.B. E_ciency of storm detention tanks for urban drainage systems under climate variability. J. Water Resour. Plan. Manag. 2012, 138, 36-46.

28. Wang, M.; Sun, Y.; Sweetapple, C. Optimization of storage tank locations in an urban stormwater drainage system using a two-stage approach. J. Environ. Manage. 2017, 204, 31-38.

29. Cunha, M.C.; Zeferino, J.A.; Simões, N.E.; Santos, G.L.; Saldarriaga, J.G. A decision support model for the optimal siting and sizing of storage units in stormwater drainage systems. Int. J. Sustain. Dev. Plan. 2017, 12, 122-132.

30. Dziopak, J. A wastewater retention canal as a sewage network and accumulation reservoir. E3S Web Conf. 2018, 45, 00016.

31. Sły's, D. An innovative retention canal-A case study. E3S Web Conf. 2018, 45, 00084.

32. Deb, K.; Pratap, A.; Agarwal, S.; Meyarivan, T. A fast and elitist multiobjective genetic algorithm: NSGA-II. IEEE Trans. Evol. Comput. 2002, 6, 182-197.

33. Martínez-Solano, F.J.; Iglesias-Rey, P.L.; Saldarriaga, J.G.; Vallejo, D. Creation of an SWMM toolkit for its application in urban drainage networks optimization. Water 2016, 8, 259.

34. Wang, Q.; Zhou, Q.; Lei, X.; Savi'c, D.A. Comparison of multiobjective optimization methods applied to urban drainage adaptation problems. J. Water Resour. Plan. Manag. 2018, 144, 04018070.

35. Raquel, C.R.; Naval, P.C. An effective use of crowding distance in multiobjective particle swarm optimization. In Proceedings of the 2005 conference on Genetic and 
evolutionary computation-GECCO, Washignotn, DC, USA, 25-29 June 2005; p. 257.

36. Mora-Melia, D.; Iglesias-Rey, P.L.; Martinez-Solano, F.J.; Ballesteros-Pérez, P. E_ciency of evolutionary algorithms in water network pipe sizing. Water Resour. Manag. 2015, 29, 4817-4831.

37. Mora-Melià, D.; Javier Martínez-Solano, F.; Iglesias-Rey, P.L.; GutiérrezBahamondes, J.H. Population size influence on the efficiency of evolutionary algorithms to design water networks. Procedia Eng. 2016, 186, 341-348.

\section{IV.7. Supplementary Material}

In the manuscript referred above, a case study was used to present the validity of the method described. It is the aim of the authors to allow any researcher to be able to reproduce the results obtained. For this reason, the data and the results are included in this supplementary material.

The network of E-Chicó is presented in the Figure 1 below.

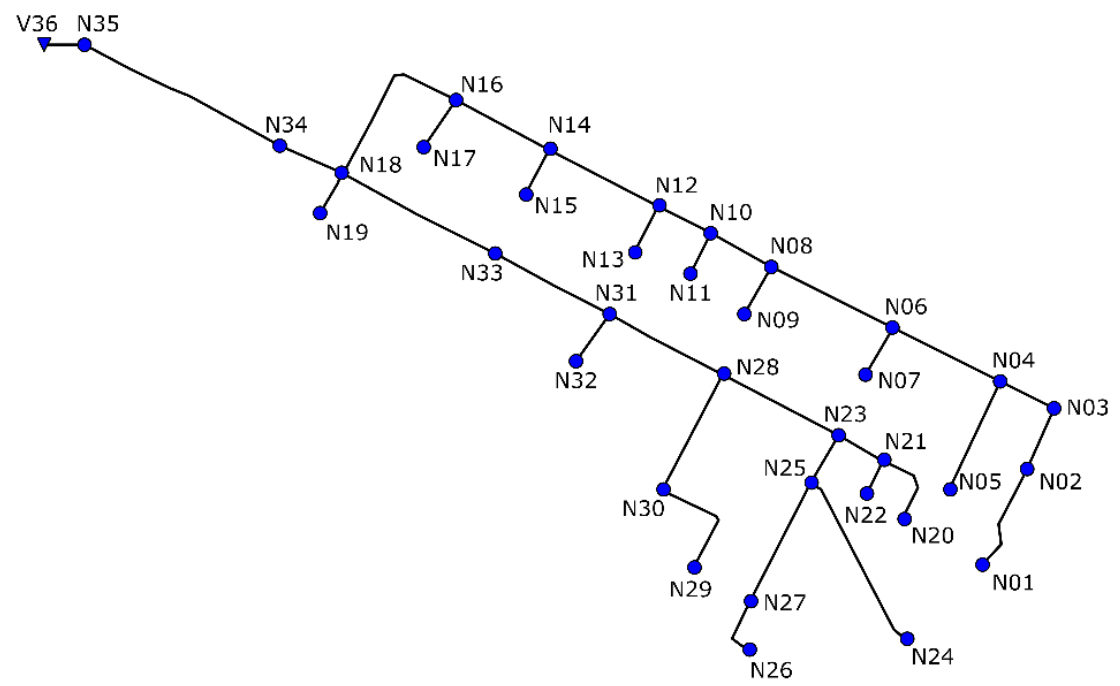

Figure 1. Representation of E-Chicó drainage network.

For the network described above, three different rehabilitation scenarios were performed depending on the selection of the decision variables. The results of these scenarios for the case of not having flooding are also presented. 


\section{Case Study Data}

Table 1. Data for nodes and subcatchments in the network used as a case study.

\begin{tabular}{cccccccc}
\hline Node & Invert & Max. & Flooding & Sub-catchment & Impervious & Width & Slop \\
ID & Elevation & Depth & Area [m2] & Area [ha] & Area [\%] & {$[\mathrm{m}]$} & {$[\%]$} \\
& {$[\mathrm{m}]$} & {$[\mathrm{m}]$} & & & & &
\end{tabular}

\begin{tabular}{lrrrrrrr}
\hline $\mathrm{N} 01$ & 2585.94 & 1.40 & 1380 & 1.38 & 73.6 & 44 & 16.9 \\
$\mathrm{~N} 02$ & 2574.53 & 2.25 & 1240 & 1.24 & 80.9 & 25 & 12.3 \\
$\mathrm{~N} 03$ & 2573.25 & 2.25 & 1080 & 1.08 & 29.2 & 84 & 27.7 \\
$\mathrm{~N} 04$ & 2567.97 & 1.72 & 930 & 0.93 & 100 & 46 & 4.8 \\
$\mathrm{~N} 05$ & 2575.26 & 2.06 & 1530 & 1.53 & 82.8 & 38 & 7.0 \\
$\mathrm{~N} 06$ & 2563.08 & 1.83 & 1890 & 1.89 & 100 & 43 & 3.1 \\
$\mathrm{~N} 07$ & 2563.67 & 2.45 & 1250 & 1.25 & 100 & 43 & 3.9 \\
$\mathrm{~N} 08$ & 2558.57 & 2.49 & 1930 & 1.93 & 100 & 45 & 3.1 \\
$\mathrm{~N} 09$ & 2560.66 & 1.32 & 1130 & 1.13 & 100 & 43 & 3.8 \\
$\mathrm{~N} 10$ & 2556.14 & 2.19 & 700 & 0.70 & 100 & 16 & 2.0 \\
$\mathrm{~N} 11$ & 2556.62 & 3.35 & 820 & 0.82 & 100 & 42 & 2.6 \\
$\mathrm{~N} 12$ & 2555.55 & 2.43 & 1730 & 1.73 & 100 & 42 & 1.1 \\
$\mathrm{~N} 13$ & 2555.97 & 2.74 & 1000 & 1.00 & 100 & 45 & 1.1 \\
$\mathrm{~N} 14$ & 2553.85 & 1.97 & 1530 & 1.53 & 100 & 40 & 0.9 \\
$\mathrm{~N} 15$ & 2555.04 & 1.38 & 1160 & 1.16 & 100 & 42 & 0.8 \\
$\mathrm{~N} 16$ & 2553.02 & 2.29 & 1480 & 1.48 & 100 & 28 & 0.7 \\
$\mathrm{~N} 17$ & 2553.31 & 2.10 & 1000 & 1.00 & 100 & 45 & 0.9 \\
$\mathrm{~N} 18$ & 2551.24 & 2.81 & 2520 & 2.52 & 100 & 27 & 0.9 \\
$\mathrm{~N} 19$ & 2552.88 & 1.38 & 470 & 0.47 & 100 & 22 & 0.8 \\
$\mathrm{~N} 20$ & 2575.59 & 1.25 & 1450 & 1.45 & 52.6 & 26 & 7.5 \\
$\mathrm{~N} 21$ & 2570.06 & 1.57 & 990 & 0.99 & 86.2 & 25 & 4.7 \\
$\mathrm{~N} 22$ & 2572.07 & 1.90 & 620 & 0.62 & 64.7 & 29 & 4.7 \\
$\mathrm{~N} 23$ & 2564.59 & 2.61 & 450 & 0.45 & 100 & 22 & 3.4 \\
$\mathrm{~N} 24$ & 2587.65 & 2.60 & 1280 & 1.28 & 61.5 & 110 & 24.4 \\
$\mathrm{~N} 25$ & 2568.14 & 2.26 & 2190 & 2.19 & 90.3 & 44 & 4.8 \\
$\mathrm{~N} 26$ & 2571.98 & 1.48 & 1250 & 1.25 & 94.8 & 29 & 3.3 \\
$\mathrm{~N} 27$ & 2571.38 & 2.42 & 1120 & 1.12 & 85.3 & 42 & 4.3 \\
$\mathrm{~N} 28$ & 2561.86 & 2.63 & 2420 & 2.42 & 100 & 48 & 3.6 \\
$\mathrm{~N} 29$ & 2569.21 & 1.53 & 1530 & 1.53 & 100 & 55 & 3.6
\end{tabular}




\begin{tabular}{lcrrrrrr}
\hline $\begin{array}{c}\text { Node } \\
\text { ID }\end{array}$ & $\begin{array}{c}\text { Invert } \\
\text { Elevation } \\
{[\mathrm{m}]}\end{array}$ & $\begin{array}{c}\text { Max. } \\
\text { Depth } \\
{[\mathrm{m}]}\end{array}$ & $\begin{array}{c}\text { Flooding } \\
\text { Area [m2] }\end{array}$ & $\begin{array}{c}\text { Sub-catchment } \\
\text { Area [ha] }\end{array}$ & $\begin{array}{c}\text { Impervious } \\
\text { Area [\%] }\end{array}$ & $\begin{array}{c}\text { Width } \\
{[\mathrm{m}]}\end{array}$ & $\begin{array}{c}\text { Slope } \\
{[\%]}\end{array}$ \\
\hline $\mathrm{N} 30$ & 2565.41 & 1.28 & 1950 & 1.95 & 100 & 49 & 3.8 \\
N31 & 2556.50 & 3.49 & 2710 & 2.71 & 100 & 21 & 2.2 \\
N32 & 2559.00 & 0.91 & 1500 & 1.50 & 90.6 & 25 & 1.9 \\
N33 & 2553.39 & 1.94 & 3030 & 3.03 & 100 & 24 & 1.1 \\
N34 & 2548.97 & 3.07 & 3270 & 3.27 & 100 & 44 & 0.5 \\
N35 & 2548.43 & 3.07 & 1210 & 1.21 & 90.6 & 20 & 0.7 \\
\hline
\end{tabular}

Table 2. Data for conduits in the network used as a case study.

\begin{tabular}{lllrrr}
\hline Link ID & Node 1 & Node 2 & Length $[\mathrm{m}]$ & $\begin{array}{c}\text { Manning } \\
\text { Roughness }\end{array}$ & Diameter [m] \\
\hline P01 & N01 & N02 & 172.65 & 0.011 & 0.40 \\
P02 & N02 & N03 & 90.99 & 0.011 & 0.40 \\
P03 & N03 & N04 & 93.17 & 0.011 & 0.40 \\
P04 & N04 & N06 & 187.94 & 0.011 & 0.55 \\
P05 & N05 & N04 & 180.27 & 0.011 & 0.40 \\
P06 & N06 & N08 & 203.82 & 0.011 & 0.60 \\
P07 & N07 & N06 & 85.55 & 0.011 & 0.40 \\
P08 & N08 & N10 & 113.02 & 0.011 & 0.75 \\
P09 & N09 & N08 & 85.62 & 0.011 & 0.40 \\
P10 & N10 & N12 & 81.80 & 0.011 & 0.75 \\
P11 & N11 & N10 & 68.24 & 0.011 & 0.30 \\
P12 & N12 & N14 & 187.31 & 0.011 & 0.90 \\
P13 & N13 & N12 & 80.08 & 0.011 & 0.40 \\
P14 & N14 & N16 & 169.06 & 0.011 & 1.10 \\
P15 & N15 & N14 & 79.98 & 0.011 & 0.50 \\
P16 & N16 & N18 & 270.92 & 0.011 & 1.20 \\
P17 & N17 & N16 & 84.81 & 0.011 & 0.40 \\
P18 & N18 & N34 & 90.38 & 0.011 & 1.30 \\
P19 & N19 & N18 & 66.74 & 0.011 & 0.40 \\
P20 & N20 & N21 & 124.22 & 0.011 & 0.45 \\
P21 & N21 & N23 & 79.16 & 0.011 & 0.45
\end{tabular}




\begin{tabular}{lllrll} 
P22 & $\mathrm{N} 22$ & $\mathrm{~N} 21$ & 52.91 & 0.011 & 0.30 \\
P23 & $\mathrm{N} 23$ & $\mathrm{~N} 28$ & 194.54 & 0.011 & 0.60 \\
P24 & $\mathrm{N} 24$ & $\mathrm{~N} 25$ & 270.94 & 0.011 & 0.56 \\
P25 & $\mathrm{N} 25$ & $\mathrm{~N} 23$ & 85.78 & 0.011 & 0.60 \\
P26 & $\mathrm{N} 26$ & $\mathrm{~N} 27$ & 91.21 & 0.011 & 0.40 \\
P27 & $\mathrm{N} 27$ & $\mathrm{~N} 25$ & 203.14 & 0.011 & 0.55 \\
P28 & $\mathrm{N} 28$ & $\mathrm{~N} 31$ & 201.07 & 0.011 & 0.75 \\
P29 & $\mathrm{N} 29$ & $\mathrm{~N} 30$ & 180.09 & 0.011 & 0.50 \\
P30 & $\mathrm{N} 30$ & $\mathrm{~N} 28$ & 197.82 & 0.011 & 0.60 \\
P31 & $\mathrm{N} 31$ & $\mathrm{~N} 33$ & 187.12 & 0.011 & 0.85 \\
P32 & $\mathrm{N} 32$ & $\mathrm{~N} 31$ & 88.46 & 0.011 & 0.40 \\
P33 & $\mathrm{N} 33$ & $\mathrm{~N} 18$ & 273.72 & 0.011 & 1.00 \\
P34 & $\mathrm{N} 34$ & $\mathrm{~N} 35$ & 337.56 & 0.011 & 1.40 \\
P35 & $\mathrm{N} 35$ & $\mathrm{~V} 36$ & 33.19 & 0.011 & 1.40 \\
\hline
\end{tabular}

I $[\mathrm{mm} / \mathrm{h}]$

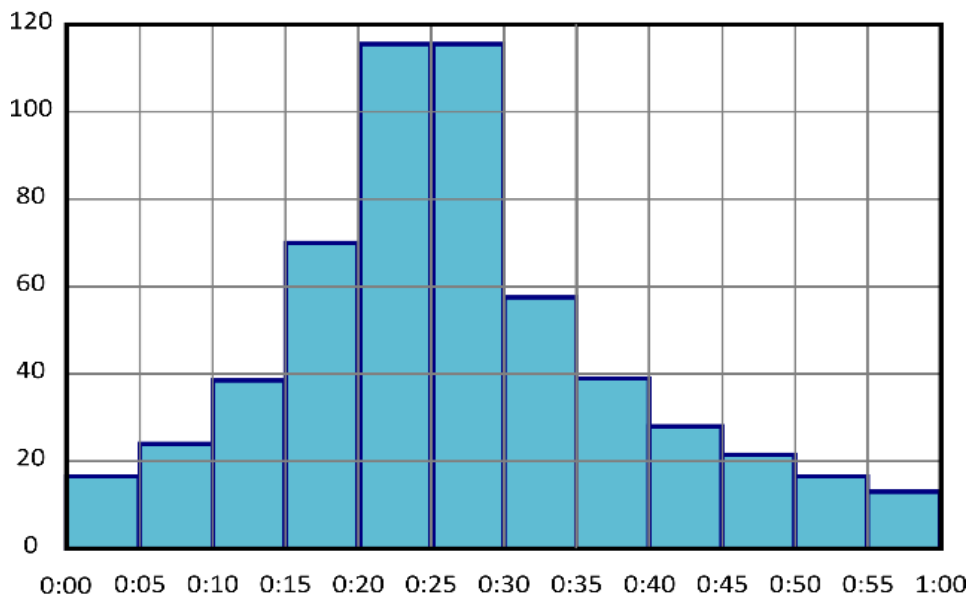

Time

Figure 2. Design storm based on the Alternating Blocks Method 
Table 3. Time series for the design storm used in the case study.

\begin{tabular}{cc}
\hline Time & Value \\
\hline $0: 00$ & 16.73 \\
$0: 05$ & 24.4 \\
$0: 10$ & 38.78 \\
$0: 15$ & 70.61 \\
$0: 20$ & 118 \\
$0: 25$ & 118 \\
$0: 30$ & 57.48 \\
$0: 35$ & 39.12 \\
$0: 40$ & 28.3 \\
$0: 45$ & 21.39 \\
$0: 50$ & 16.73 \\
\hline
\end{tabular}

Table 4. Series of suitable diameters and their associated for the case study.

\begin{tabular}{cc}
\hline Diameter $[\mathrm{m}]$ & Unit Cost $[€ / \mathrm{m}]$ \\
\hline 0.30 & 30.93 \\
0.35 & 39.73 \\
0.40 & 49.56 \\
0.45 & 60.44 \\
0.50 & 72.36 \\
0.60 & 99.31 \\
0.70 & 130.43 \\
0.80 & 165.71 \\
0.90 & 205.15 \\
1.00 & 248.75 \\
1.10 & 296.51 \\
1.20 & 348.43 \\
\hline
\end{tabular}

\begin{tabular}{cc}
\hline Diameter $[\mathrm{m}]$ & Unit Cost $[€ / \mathrm{m}]$ \\
\hline 1.30 & 404.51 \\
1.40 & 464.76 \\
1.50 & 529.16 \\
1.60 & 597.73 \\
1.80 & 747.35 \\
1.90 & 828.40 \\
2.00 & 913.61 \\
2.20 & 1096.52 \\
2.40 & 1296.07 \\
2.60 & 1512.27 \\
2.80 & 1745.11 \\
3.00 & 1994.60 \\
\hline
\end{tabular}

\section{Results of the Case Study}

Next, the results of these scenarios for the case of not having flooding are presented. 
Table 5. Results for scenario 1, all 35 conduits are suitable to change their diameters.

\begin{tabular}{|c|c|c|c|}
\hline Link ID & $\begin{array}{c}\text { Original } \\
\text { Diameter }[\mathrm{mm}]\end{array}$ & New Diameter [mm] & Cost $[€]$ \\
\hline P01 & 400 & 400 & $0.00 €$ \\
\hline $\mathrm{P} 02$ & 400 & 800 & $15,077.63 €$ \\
\hline $\mathrm{P} 03$ & 400 & 1000 & $23,175.57 €$ \\
\hline P04 & 550 & 700 & $24,512.81 €$ \\
\hline P05 & 400 & 400 & $0.00 €$ \\
\hline P06 & 600 & 800 & $33,774.28 €$ \\
\hline P07 & 400 & 500 & $6,190.18 €$ \\
\hline P08 & 750 & 1100 & $33,511.12 €$ \\
\hline P09 & 400 & 400 & $0.00 €$ \\
\hline P10 & 750 & 1200 & $28,501.44 €$ \\
\hline P11 & 300 & 400 & $3,382.22 €$ \\
\hline $\mathrm{P} 12$ & 900 & 1100 & $55,538.56 €$ \\
\hline P13 & 400 & 900 & $16,428.02 €$ \\
\hline P14 & 1100 & 1400 & $78,571.75 €$ \\
\hline P15 & 500 & 450 & $4,834.02 €$ \\
\hline P16 & 1200 & 1300 & $109,590.36 €$ \\
\hline P17 & 400 & 600 & $8,422.70 €$ \\
\hline P18 & 1300 & 1400 & $42,004.70 €$ \\
\hline P19 & 400 & 1000 & $16,601.24 €$ \\
\hline $\mathrm{P} 20$ & 450 & 450 & $0.00 €$ \\
\hline $\mathrm{P} 21$ & 450 & 450 & $0.00 €$ \\
\hline $\mathrm{P} 22$ & 300 & 800 & $8,767.53 €$ \\
\hline $\mathrm{P} 23$ & 600 & 800 & $32,236.52 €$ \\
\hline $\mathrm{P} 24$ & 560 & 500 & $19,604.54 €$ \\
\hline $\mathrm{P} 25$ & 600 & 1000 & $21,337.35 €$ \\
\hline P26 & 400 & 800 & $15,114.08 €$ \\
\hline P27 & 550 & 1300 & $82,172.55 €$ \\
\hline $\mathrm{P} 28$ & 750 & 900 & $41,248.53 €$ \\
\hline P29 & 500 & 450 & $10,884.71 €$ \\
\hline P30 & 600 & 900 & $40,581.80 €$ \\
\hline P31 & 850 & 1100 & $55,482.22 €$ \\
\hline P32 & 400 & 450 & $5,346.56 €$ \\
\hline P33 & 1000 & 1300 & $110,723.00 €$ \\
\hline
\end{tabular}




\begin{tabular}{cccr}
\hline Link ID & $\begin{array}{c}\text { Original } \\
\text { Diameter [mm] }\end{array}$ & New Diameter [mm] & \multicolumn{1}{l}{ Cost [€] } \\
\hline P34 & 1400 & 1800 & $252,274.59 €$ \\
P35 & 1400 & 1500 & $17,562.90 €$ \\
\hline Total & & & $1,213,453.48 €$ \\
\hline
\end{tabular}

Table 6. Results for scenario 2, all 35 nodes are suitable locations for detention tanks

\begin{tabular}{|c|c|c|c|}
\hline Node ID & Max. Depth [m] & Volume [m3] & Cost $[€]$ \\
\hline N01 & 1.40 & 100 & $24,828.79 €$ \\
\hline N02 & 2.25 & 200 & $33,809.91 €$ \\
\hline N03 & 2.25 & 0 & $0.00 €$ \\
\hline N04 & 1.72 & 300 & $35,380.99 €$ \\
\hline N05 & 2.06 & 250 & $35,357.73 €$ \\
\hline N06 & 1.83 & 600 & $47,077.61 €$ \\
\hline N07 & 2.45 & 100 & $28,297.18 €$ \\
\hline N08 & 2.49 & 0 & $0.00 €$ \\
\hline N09 & 1.32 & 150 & $26,826.63 €$ \\
\hline N10 & 2.19 & 400 & $42,959.93 €$ \\
\hline N11 & 3.35 & 400 & $51,245.61 €$ \\
\hline N12 & 2.43 & 0 & $0.00 €$ \\
\hline N13 & 2.74 & 100 & $29,155.07 €$ \\
\hline N14 & 1.97 & 250 & $34,830.14 €$ \\
\hline N15 & 1.38 & 0 & $0.00 €$ \\
\hline N16 & 2.29 & 0 & $0.00 €$ \\
\hline N17 & 2.10 & 550 & $48,086.08 €$ \\
\hline N18 & 2.81 & 1250 & $81,134.49 €$ \\
\hline N19 & 1.38 & 0 & $0.00 €$ \\
\hline $\mathrm{N} 20$ & 1.25 & 0 & $0.00 €$ \\
\hline $\mathrm{N} 21$ & 1.57 & 0 & $0.00 €$ \\
\hline $\mathrm{N} 22$ & 1.90 & 300 & $36,614.59 €$ \\
\hline $\mathrm{N} 23$ & 2.61 & 650 & $56,933.33 €$ \\
\hline $\mathrm{N} 24$ & 2.60 & 0 & $0.00 €$ \\
\hline
\end{tabular}




\begin{tabular}{rrrr}
\hline $\mathrm{N} 25$ & 2.26 & 0 & $0.00 €$ \\
$\mathrm{~N} 26$ & 1.48 & 0 & $0.00 €$ \\
$\mathrm{~N} 27$ & 2.42 & 0 & $0.00 €$ \\
$\mathrm{~N} 28$ & 2.63 & 0 & $0.00 €$ \\
$\mathrm{~N} 29$ & 1.53 & 150 & $27,824.11 €$ \\
$\mathrm{~N} 30$ & 1.28 & 0 & $0.00 €$ \\
$\mathrm{~N} 31$ & 3.49 & 0 & $0.00 €$ \\
$\mathrm{~N} 32$ & 0.91 & 1350 & $49,361.14 €$ \\
$\mathrm{~N} 33$ & 1.94 & 150 & $29,643.16 €$ \\
$\mathrm{~N} 34$ & 3.07 & 0 & $0.00 €$ \\
$\mathrm{~N} 35$ & 3.07 & 0 & $0.00 €$ \\
\hline Total & & & $719,366.52 €$ \\
\hline
\end{tabular}

Table 7. Results for scenario 3, all 35 conduits are suitable to change their diameters and all 35 nodes are suitable locations for detention tanks

\begin{tabular}{rrrrrrrr}
\hline $\begin{array}{c}\text { Link } \\
\text { ID }\end{array}$ & $\begin{array}{c}\text { Original } \\
\text { Diameter } \\
{[\mathrm{mm}]}\end{array}$ & $\begin{array}{c}\text { New } \\
\text { Diameter } \\
{[\mathrm{mm}]}\end{array}$ & \multicolumn{1}{c}{ Cost $[€]$} & $\begin{array}{c}\text { Node } \\
\text { ID }\end{array}$ & $\begin{array}{c}\text { Max. } \\
\text { Depth }[\mathrm{m}]\end{array}$ & Volume [m3] & Cost [€] \\
\hline P01 & 400 & 400 & $0.00 €$ & N01 & 1.40 & 0 & $0.00 €$ \\
P02 & 400 & 300 & $2,814.40 €$ & N02 & 2.25 & 250 & $36,445.79 €$ \\
P03 & 400 & 400 & $0.00 €$ & N03 & 2.25 & 0 & $0.00 €$ \\
P04 & 550 & 550 & $0.00 €$ & N04 & 1.72 & 0 & $0.00 €$ \\
P05 & 400 & 400 & $0.00 €$ & N05 & 2.06 & 300 & $37,677.14 €$ \\
P06 & 600 & 300 & $6,304.34 €$ & N06 & 1.83 & 1450 & $70,434.18 €$ \\
P07 & 400 & 400 & $0.00 €$ & N07 & 2.45 & 0 & $0.00 €$ \\
P08 & 750 & 600 & $11,224.31 €$ & N08 & 2.49 & 0 & $0.00 €$ \\
P09 & 400 & 400 & $0.00 €$ & N09 & 1.32 & 0 & $0.00 €$ \\
P10 & 750 & 750 & $0.00 €$ & N10 & 2.19 & 1550 & $79,723.98 €$ \\
P11 & 300 & 300 & $0.00 €$ & N11 & 3.35 & 0 & $0.00 €$ \\
P12 & 900 & 350 & $7,441.28 €$ & N12 & 2.43 & 0 & $0.00 €$ \\
P13 & 400 & 400 & $0.00 €$ & N13 & 2.74 & 0 & $0.00 €$ \\
P14 & 1100 & 1100 & $0.00 €$ & N14 & 1.97 & 0 & $0.00 €$ \\
P15 & 500 & 500 & $0.00 €$ & N15 & 1.38 & 500 & $39,218.34 €$
\end{tabular}




\begin{tabular}{rrrrrrrr} 
P16 & 1200 & 1200 & $0.00 €$ & $\mathrm{~N} 16$ & 2.29 & 0 & $0.00 €$ \\
P17 & 400 & 400 & $0.00 €$ & $\mathrm{~N} 17$ & 2.10 & 0 & $0.00 €$ \\
P18 & 1300 & 1300 & $0.00 €$ & $\mathrm{~N} 18$ & 2.81 & 0 & $0.00 €$ \\
P19 & 400 & 400 & $0.00 €$ & $\mathrm{~N} 19$ & 1.38 & 0 & $0.00 €$ \\
P20 & 450 & 450 & $0.00 €$ & $\mathrm{~N} 20$ & 1.25 & 0 & $0.00 €$ \\
P21 & 450 & 400 & $3,923.45 €$ & $\mathrm{~N} 21$ & 1.57 & 0 & $0.00 €$ \\
P22 & 300 & 300 & $0.00 €$ & $\mathrm{~N} 22$ & 1.90 & 0 & $0.00 €$ \\
P23 & 600 & 600 & $0.00 €$ & $\mathrm{~N} 23$ & 2.61 & 0 & $0.00 €$ \\
P24 & 560 & 560 & $0.00 €$ & $\mathrm{~N} 24$ & 2.60 & 0 & $0.00 €$ \\
P25 & 600 & 300 & $2,653.25 €$ & $\mathrm{~N} 25$ & 2.26 & 1300 & $74,096.64 €$ \\
P26 & 400 & 450 & $5,512.77 €$ & $\mathrm{~N} 26$ & 1.48 & 0 & $0.00 €$ \\
P27 & 550 & 500 & $14,698.70 €$ & $\mathrm{~N} 27$ & 2.42 & 0 & $0.00 €$ \\
P28 & 750 & 750 & $0.00 €$ & $\mathrm{~N} 28$ & 2.63 & 1000 & $70,125.66 €$ \\
P29 & 500 & 500 & $0.00 €$ & $\mathrm{~N} 29$ & 1.53 & 0 & $0.00 €$ \\
P30 & 600 & 300 & $6,118.75 €$ & $\mathrm{~N} 30$ & 1.28 & 950 & $49,146.22 €$ \\
P31 & 850 & 850 & $0.00 €$ & $\mathrm{~N} 31$ & 3.49 & 0 & $0.00 €$ \\
P32 & 400 & 400 & $0.00 €$ & $\mathrm{~N} 32$ & 0.91 & 0 & $0.00 €$ \\
P33 & 1000 & 1000 & $0.00 €$ & $\mathrm{~N} 33$ & 1.94 & 0 & $0.00 €$ \\
P34 & 1400 & 1400 & $0.00 €$ & $\mathrm{~N} 34$ & 3.07 & 0 & $0.00 €$ \\
P35 & 1400 & 1400 & $0.00 €$ & $\mathrm{~N} 35$ & 3.07 & 0 & $0.00 €$ \\
\hline Total & & & $60,691.26 €$ & & & & $456,867.95 €$ \\
\hline & & & & & & \\
\hline
\end{tabular}




\section{Appendix V}

\section{Urban drainage networks rehabilitation using multi- objective model and search space reduction methodology}

\section{Reference:}

Ngamalieu-Nengoue, U.A.; Iglesias-Rey, P.L.; Martínez-Solano, F.J. Urban Drainage Networks Rehabilitation using Multi-Objective Model and Search Space Reduction Methodology. Infrastructures 2019, vol. 4, no. 2, pp. 35. https://doi.org/10.3390/infrastructures4020035 


\begin{abstract}
Drainage network always needs to adapt to the environmental and climatic conditions to provide best quality services. Rehabilitation combining pipes substitution and storm tanks installation appears as a good solution to overcome this problem. Unfortunately, the calculation time of such rehabilitation scenario is too elevated for single-objective and multi-objective optimization. In this study, a methodology composed by search space reduction methodology whose purpose is to decrease the number of decision variables of the problem to solve and a multi-objective optimization whose purpose is to optimize the rehabilitation process and represent Pareto fronts as results of urban drainage networks optimization is proposed. A comparison between different model results for multi-objective optimization is made. To obtain these results, Storm Water Management Model (SWMM) is first connected to a Pseudo Genetic Algorithm (PGA) for the search space reduction, then to a NSGA-II for the multiobjective optimization. Pareto fronts are designed for investment costs versus flood damage costs. The methodology is applied to a real network in the city of Medellin in Colombia. The results show the search space reduction methodology provides models with a considerably reduced number of decision variables. The multi-objective optimization shows that results of the models used after the search space reduction obtain better results than complete model in terms of calculation time and optimality of the solutions.
\end{abstract}

Keywords: drainage networks; extreme rainfalls; search space reduction; rehabilitation; multi-objective optimization; SWMM.

\title{
V.1. Introduction
}

Urban drainage networks experience failures in their operation due to aging and other structural problems, but also due to urbanization and climate change, that is affecting the intensities and frequencies of extreme rainfall events. One of the objectives of rehabilitation is to avoid the consequences of extreme events, drainage networks should be adapted to the new climatologic and environmental conditions. Jeong et al. [1] said that if a rainfall event is higher than infrastructure facilities capacity, their neighboring assets will be spoiled, and this will provoke a flood. Climate change adaptation in the infrastructure sector mitigates these damages by expanding the capacity of existing facilities or by installing new ones. According to Quinn et al. [2], extreme events cause damages to public infrastructures, so they presented a methodology composed of an adaptation strategy and an implementation plan allowing transport infrastructures to mitigate the climate change effects with the aim of avoiding service disruption and the associated financial costs. Additionally, to be flexible to the 
incorporation of new knowledge, the implementation of their methodology aims to help users to assess their adaptation grade and try to strengthen it. Szewrański et al. [3] developed a pluvial flood risk assessment tool to support stakeholders in rainwater management and adapt existing networks to climate change. Their tool implements spatial identification of flooding vulnerable areas and can be used in areas with different sizes. This tool can be used for the identification of rainfall flood risk in new developed area and help in flood monitoring in disaster recovery centers. Jeong et al. [1] showed how adaptation costs could be managed through a framework based on game theory. The aim of their study was proposing a suitable framework to allocate adaptation costs among local governments. One of the conclusions of the work of Jeong et al. was that the allocation of costs of climate change adaptation among stakeholders allowed to solve some conflicts. Silva and Costa [4] enumerated the challenges faced by climate change adaptation and referred to public space as powerful way to help in climate change adaptation. In addition to the fact that public space promotes adaptation action and help to reduce risk of catastrophes, they improve awareness on climate change. Therefore, everybody should be a public space manager in the sense of help in climate change adaptation. The involvement of people and communities in the urban vulnerability management leads to adequate solutions in the adaptation to climate change. These studies clearly show that adaptation is an important process to overcome the problem such as floods caused by extreme rainfall events.

There are different approaches in the literature to reduce or eliminate floods. There are traditional solutions based on the replacement of existing conduits by others of greater capacity. Other more recent solutions are based on the control of runoff generated. It is what are called Low Impact Developments (LID). Additionally, there are solutions based on the operational control of the network. These are the so-called Real Time Control (RTC) solutions, based on operating the different elements of the network in order to reduce concentration times and minimize flooding. Finally, there are methodologies based on the application of several of the previous techniques. These generally use optimization algorithms that can be single or multi-objective.

Zhang et al. [5] proposed a traditional engineering method consisting on increasing pipes capacity and the use the free space as storage environment during extreme events. The main objective was to increase the response time and reduce the overflow at the wastewater treatment plant. The increase of pipe diameters alone was not adequate to eliminate overflow. Prasad et al. [6] developed a comprehensive list of parameters affecting stormwater pipe performance. They also developed a performance index using a fuzzy inference method to capture interdependencies among parameters. Sedimentation is a phenomenon that seldom occurs in conduits and has the following consequences: reduction of the cross section of the conduit, reduction of the transportation capacity and provoking floods. Pipe characteristics determine the structural condition. In that way, frequent maintenance is needed to solve sedimentation and blockage problems. Song et al. [7] carried out a study on the prevention of 
sedimentation in urban drainage conduits. They concluded that sedimentation should be taken into consideration when a drainage network is designed. Song et al. showed that low velocity of incoming sludge and big particles sizes promote sludge deposition and reduce pipes transportation capacities. During years, canalization was used to reduce floods. It has been substituted by other methods due to its ineffectiveness ahead of floods caused by environmental conditions and urbanization adverse effects [8].

The other method considered to solve problem posed is the RTC. According to Kroll et al. [9], sewer networks managers hesitate to implement RTC to manage their system, they proposed a strategy for RTC and they obtained satisfactory results in term of CSO reduction. They concluded that RTC strategy achieves better results when the control locations are well selected. Vermuyten et al. [10] presented a meta-heuristic approach based on genetic algorithm and model predictive control for flood RTC. Their algorithm did not find the optimal solution but rapidly converged to a solution near of the optimal one. For the same optimal control parameters, their approach provided better results in damage costs reduction than the programmable logic controller (PLC) did. Direct flood mitigation implies a risk of failure due to unexpected structural defections that can occur during rainfall events. Therefore, despite the effectiveness of RTC in flood damages reduction, networks managers hesitate to implement this option.

There are preventives methods implying that actions must be taken before to avoid the occurrence of floods. So, the notion of risk arose. The idea is to identify the flood risks and take necessary structural and non-structural actions to prevent its occurrence. Salinas-Rodriguez et al. [11] presented the difference between standardsbased approach, which has many limitations, and the risk-based approach, which include flood hazard and impact assessments. Their method involves stakeholders when defining risk level, prevents and gives variety of possible actions for the network adaptation against frequent extreme rainfall events. The method also allows drawing the flooding risk map of the study area. Implementing the approach will be useful in drainage networks management and help to deal with extreme rainfall events. Scionti et al. [8] proposed a quasi-2d model composed of the $1 \mathrm{D}$ model simplicity and the $2 \mathrm{D}$ model having the ability to better represent the surface flows and connected it to MODCEL, which can discretize the urban area in cells where rainfall-runoff transformation is operated. The flood risk index considered in the study links flood level to flood damage cost and the model provides important data in term of flood risk and level for critical areas and various scenarios of flood reduction. The methodology is a decision support tool that can allow the localization, assessment and comparison of flood risk's determining areas and grade. Caldas et al. [12] studied the flood vulnerability of Batatais municipality in Sao Polo, Brazil. All the parameters used to characterize the flood vulnerability have been evaluated through the analytic hierarchy process (AHP) method. Vulnerability maps were drawn based on geographical information system (GIS) assets and historic flood events. Effects of flood intensity have been presented for environmental land use conflicts and results showed that the vulnerability area in that municipality occupied $60 \%$ of the area. Such studies would be helpful in the adequate use of soil and water resources of region. Since decision makers prefer implementation 
of grey measures which are suitable for moderate rainfall events in one hand. And green measures are effective against runoff excess in the other hand Alves et al. [13] combined both measures in an approach to make it reliable and adaptable to climate change effects. The approach considers multicriteria decision analysis which provides results in form of information to help decision makers to well select the suitable solution for their specific problem. A tool implementing the methodology has been carried out and applied to cases studies and, the results showed that the tool is reliable, helpful and convenient. For flooding mitigation, Kolen and Van Gelder [14] proposed a risk-based decision model which is a tool providing a set of decisions to be implemented by decision makers to plan evacuation and reduce flood damage costs and lives losses. Elaboration and implementation of evacuation diagram would be useful in live losses reduction during floods. Risk-based approach seems to be effective method for flood prevention and in urban network adaptation, but they can face the problem of implementation by the managers or decision makers. All the precedents works are related by the fact that they are solutions of adaptation of drainage network to new climatic and environmental conditions. Even if those approaches are reliable in some situations such as those they solve, they unfortunately became inefficient with the time. The need of implementation of better solutions is then required.

A new trend in last decades consisted into installing some hydraulic assets to reduce the conductivity of the runoff or to store the excess of water during rainfall events and later re-introduce that water in the system and convey it to water treatment plant. These assets are designated by several names: Green Infrastructures, Best Management Practices, Sustainable urban drainage and Low impact development practices. There are many studies in the literature implementing those measures. Song et al. [15] proposed a water management analysis module (WMAM) framework based on LID practices integrated box in SWMM to establish a reliable design and plan parameters related to LID practices implementation. The methodology has been applied for an infiltration trench and the results showed that they considerably reduce runoff. The WMAM allows defining the adequate design of the LID and the corresponding parameters while reducing flooding. De Paola et al. [16] implemented a Decision Support System on two cases studies using SWMM as hydraulic analysis tool and Harmony search as optimization method. The aim of their study was the reduction of flooding volume while minimizing the objective function. The proposed strategy started with territorial analysis in Geographical Information System (GIS) then a setting of the network and finally an optimization. In the context of extreme rainfalls, the proposed model can select and implement adequate LID practices to reduce floods and ensure minimal investments. Xiao et al. [17] evaluated the effectiveness of bioswales on stormwater runoff quality and quantity. Their treatment bioswale eliminated more than $99 \%$ of surface runoff, but this ability of the bioswale gradually decreased due to the underlying soil layer saturation. It was also effective in pollutants removal and support trees growth in an urban landscape. Integrate Engineering Soil Mixed in Bioswales is an effective solution 
for stormwater runoff reduction. Martínez et al. [18] proposed a framework aiming to select and install a green infrastructure between Bio-retention cells, infiltration trenches, porous pavement and vegetation swales. The main objective of their study was urban runoff reduction, improvement of water quality while reducing investment costs. To achieve it, SWMM was connected to non-dominated sorting genetic algorithm II (NSGA-II) for simulations and optimization. Pareto fronts were presented for flooding volumes against investment costs and for pollution loads against investment costs. For the same investment amount, a smaller number of porous pavements needed to be installed to achieve good results for any type of rainfall events. Three types of pavements were used by Hu et al. [19] to investigate their capacity on flood reduction and the effects of clogging and first water quality on permeable pavement performance in a sponge city. 12 scenarios were generated, and the results showed that permeable pavements reduced urban runoff and that clogging affected the performance of permeable pavements. The limit of their study was the reduced number of calibration and validation information. Earliest water quality reduces pavements performance, but permeable asphalts implementation provides better results. Leimgruber et al. [20] studied the impact of the installation of 3 LIDs on the water balance using long term simulation. They wanted to provide the influential parameters list to practitioners. Results should be integrated in a complete water balance considering LID configured in SWMM. Unfortunately, results of Leimgruber et al. showed that by increasing the substrate thickness of green roofs, the retention rate increased. Green roof runoff retention capacity lays on various parameters, so Gong et al. [21] for several rainfall events and 10 extensive green roof modules studied the effects of various parameters on the green roof runoff retention capacity. Their results showed that green roofs were effectives for rainfall events of moderate intensity and were affected by extreme rainfall events. Mora et al. [22] also obtained results showing that green roofs as LID practices are efficient for moderate rainfall events, but their implementation cannot prevent the generation of flood for extreme rainfall events. So, green infrastructures are effectives for moderate rainfall events but cannot deal with extreme rainfall events. Therefore, there is a necessity to have a better asset to overcome this problem.

The last category of authors considered that drainage network simply must be rehabilitated based on the objectives to achieve. Rehabilitation strategies of singleobjective or multi-objective have been proposed. Vojinovic et al. [23] proposed a multiobjective approach for drainage network rehabilitation. Appropriate modifications were operated in SWMM. Latin Hypercube Sampling was used to sample statistical distribution and uncertainty while NSGA-II was applied to provide the set of optimal solutions. Two approaches were implemented: the first considering uncertainty in objective function which provided globally the best results and the second considering uncertainty in the optimization process. To achieve strong results, uncertainties impacts should be considered in drainage network optimal rehabilitation. Lim et al. [24] presented a drainage network multi-objective rehabilitation approach considering the installation of detention facilities and the optimization of their locations and capacity by a multi-objective genetic algorithm. The aim was the total overflow reduction while 
minimizing the investment. The methodology will be helpful for managers in the effective selection and installation of retention assets in drainage networks. What they did not considered in their study is the substitution of pipe and they did not consider search space reduction. In this work, we consider both pipes renewal and storm tanks installation. Also, a search space reduction model resolution is proposed and compared with the complete model rehabilitation. $\mathrm{Xu}$ et al. [25] proposed a rehabilitation methodology to improve the capacity of drainage networks in the city of Fuzhou, China. Their methodology considered climate change and adopted a periodic installation of storage facilities and pump to reduce floods damages while reducing the investment costs. It was suggested that the methodology be implemented throughout the city of Fuzhou. Yazdi [26] proposed an optimal methodology for drainage networks rehabilitation and flooding mitigation, considering effects of unexpected structural failures during rainfall events. To achieve this, he connected SWMM to non-dominated sorting differential evolution to track the set of optimal solutions. Martínez et al. [27] presented a multi-objective approach combining 1D/2D model to a NSGA-II to rehabilitate drainage networks in order to help them in the process of adaptation to climate change and reduction of flood damage costs. The major inconvenient of the methodology was that it needed elevated calculation time to find the set of optimal solutions. The combine use of pipes substitution and storage facilities installation provides better results than each measure implemented alone. Ngamalieu-Nengoue et al. [28] proposed a single-objective optimization methodology to reduce the search space of the problem and reduce the calculation time while obtaining better results. The NSGAII [29] which includes an elitism consisting on keep two individuals in each generation was proposed by Ngamalieu-Nengoue et al. [30] to solve multi-objective rehabilitation of drainage networks considering pipes substitution and storm tanks installation. Drainage networks rehabilitation considering pipe substitution combined to storm tanks installation presents good results, but the elevated calculation time needed to obtain them is a serious problem that can hinder the obtention of the global optimal solution.

A new challenge in the optimization of water resources management is the reduction of the computation time and the obtention of better results. To achieve this, some authors proposed the reduction of solution space to help the optimization algorithm to find the optimal solution by providing it a better exploration capacity. Maier et al. [31] presented the new challenges such as reduction of solution space and applied them to water resources management, while Sophocleous et al. [32] proposed the reduction of solution space to the leak localization in real water distribution. After the assessment of the robustness of their methodology, it could be applied in the industry.

The state of art discussion shows that to adapt networks to climatic conditions, authors concentrated more efforts to work on methodologies such as RTC that network manager hesitate to implement. They also dedicated many studies on LID implementation which is inefficient for extreme rainfall events. The reduction of search space as new challenge is a good approach to reduce computation time in water resource 
management. Therefore, the main objective of this study is to propose a multi-objective optimization for urban drainage networks rehabilitation strategy that first apply a search space reduction methodology to reduce the size of the addressed problem, then a multiobjective evolutionary algorithm is applied for the optimization of the search space reduction model obtained. The methodology considers pipes substitution and storm tanks installation in the network.

\section{V.2. Problem formulation}

Drainage networks are civil engineering infrastructures present in several countries around the world. Their main mission is to drain rainfall water of the cities where they are installed.

During last decades, rainfalls intensities and frequencies increased converting them into extreme rainfalls events which caused insufficiencies to drainage networks. The network capacity is reduced, and floods appear. In this work, a two parts methodology to solve this problem is presented.

The starting hypotheses considered are the following:

- Scenarios damaging considerably the networks are those that should be used during the optimization process. The rehabilitation will be operated considering only the worst scenario obtained.

- The rain-runoff transformation considered in this study is one within SWMM models, named Curve Number model. Basically, SWMM is composed of three different models for the rainfall-runoff transformation: Horton, Green-Ampt and SCS Curve Number models. The latter option was adopted due to the fact that it was the simplest one and there is only one parameter needed which is the Curve Number. Once the rainfall-runoff transformation has been calculated, the hydraulic model just takes into account inflows at nodes instead of precipitation scenarios.

- There are various calibration models and the calibration of the network is important as can be seen in these papers [33-35], but calibration is beyond the scope of this work. So, SWMM [36] will be used and the hydraulic model of the drainage network will be the starting point of the process. The model will be analyzed using a dynamic wave model to obtain a better representation of flood rather than the uniform flow which is generally used in this case.

- Every model must be simplified, so that the accuracy of the result must not be compromised. The aim of the simplification is to highly reduce calculation times of each hydraulic simulation.

- The corrective actions will be storm tanks installation and pipes diameters modification. Volume of tanks will be calculated and assigned to those to be installed and new diameters of pipes will also be calculated and assigned. A full range of commercial diameters and their installing costs is provided [28]. 
- Storm tanks to install will have the following characteristics: single chamber, in-line tank and no control device. The storm tanks will be installed on the corresponding node location and only the base area will be modified according to the calculated value.

- It is in monetary units that the optimization problem will be addressed. First, hydraulic variables will be defined as monetary units in some costs functions as presented by Cunha et al. [37] and Ngamalieu-Nengoue et al. [28].

- Heuristic approaches will be effective to optimize the mathematical formulation of the problem. Based on precedent studies a Pseudo-genetic Algorithm [38] method is used.

The approach consists into rehabilitate the drainage network by renewing pipes and installing storm tanks in some nodes. The problem encountered in this case is that the calculation time is elevated, and the objective function best value is caught up in a local minimum, the probability to obtain repetitive solution is elevated. Due to a wide solution space, the search of the best solution is difficult. The aim of this work is to propose a multi-objective optimization methodology of drainage networks. The methodology first applies a search space reduction methodology to reduce the size of the addressed problem. A multi-objective evolutionary algorithm is then applied to the optimization of the reduced problem size obtained.

\section{V.2.1. Cost functions}

To assess rehabilitation costs, there are three terms: Pipes substitution costs, storm tanks installation costs and flooding costs. These costs allow representing mathematical values in monetary units. In the following are presented the expressions of those cost functions.

\section{Pipe substitution cost function}

From real data supplied by pipe manufacturers, a mathematical formulation to express the cost of pipe installation in Euros per meter has been carried out. This cost depends on the diameter of the pipe to be installed. The cost grows with the diameter size.

$$
C_{C}\left(D_{i}\right)=A \cdot D_{i}+B \cdot D_{i}^{2}
$$

In equation (1), A and B represent adjusts coefficients.

\section{Storm tank installation cost function}

Depending on the calculated volume of a storm tank $\left(V_{j}\right)$ that can be installed on a node of the network to collect and store extra water during extreme events, this cost 
function can be defined using real data supplied by manufacturers. These tank's sizes can be small and medium with the aim to expand the storage capacity of the nodes or the original installed storm tanks existing in the network. The first term of the formulation represents the minimum cost relative to the construction $\left(C_{m i n}\right)$ and the second term depends on the total volume through a constant $\left(C_{v a r}\right)$ and an exponent $(n)$. The first term is fixed while the second is variable:

$$
C_{T}\left(V_{j}\right)=C_{\min }+C_{v a r} \cdot V_{j}^{n}
$$

\section{Flood damage cost function}

In the literature, flooding is considered as a volume for some authors [39] while other authors consider flooding as the highest depth reach by the water $(y)$ out of the network. According to Lee and Kim [40], flooding damage is different from flooding volume. They showed that some subareas can be immediately damaged by a certain amount of flooding while other subareas are not, confirming that flood damage depend on the land use. As flood damage costs represent the damages provoked by the flooding, Lee and Kim [40] represented flood damage costs in function of the depth reached by water. On the base of their model, flood damage cost function was expressed as a function of the depth $(y)$ of the flooding.

The ponded area model proposed by SWMM allows defining the ponded area $\left(\mathrm{A}_{\mathrm{p}}\right)$ related to each node. Then, by dividing the flooding volume $\left(\mathrm{V}_{\mathrm{fl}}\right)$ by the ponded area, the highest depth reached by the water or the flood level can be obtained. Flood damage cost is given by the following equation:

$$
C_{I}\left(y_{k}\right)=C_{\max } \cdot\left(1-e^{-k \frac{y_{k}}{y_{\max }}}\right)^{2}
$$

In Equation (3), $C_{\max }$ stand as the maximum cost per square meter that a flooding can cause. The constant $\left(y_{\max }\right)$ is the fixed depth where the damage is considered as irrecoverable so that, it stops the increase of the function, causing the attainment of the maximum cost value $\left(V_{\max }=1.4\right)$. The exponent $\mathrm{k}$ is an adjusting coefficient based on historical data of damages provoked by flooding $(k=4.89)$. In all the cases, equation (3) depends totally on the value of $C_{\max }$ whose values are presented in Table 1.

Table 1: $C_{\max }$ values for different social Stratum (Str) linked to land uses

\begin{tabular}{cccccccccc}
\hline Land Use & Str. 1 & Str. 2 & Str. 3 & Str. 4 & Str. 5 & Str. 6 & Commercial & Industrial & Average \\
$C_{\max }\left(€ / \mathrm{m}^{2}\right)$ & 142 & 245 & 257 & 584 & 732 & 1168 & 3975 & 3041 & 1267 \\
\hline
\end{tabular}




\section{V.2.2. Objective functions}

When an optimization problem is addressed, there is always an objective function to optimize. In this work, the problem size reduction is based on the optimization of a single objective function. The obtained values of the optimization are ranked in order to perform the selection of nodes and conduits allowing to form the reduced problem size. That is the reason why a single-objective function is presented. The multi-objective optimization which is the main optimization to be operated in this work is characterized by two conflicting objective functions. They are represented on a side by the investment costs and on the other side by the flood damage costs. More investments reduced flood damage costs and vice versa.

\section{Problem size reduction methodology: Single objective function}

The main objective of the optimization is the minimization of the objective function. In the case of the search space reduction methodology, the objective function $(F)$ is the sum of the three costs functions presented. The obtained results represent a monetary value of the total cost necessary to rehabilitate the network. The mathematical expression is represented by Equation (4):

$$
F=\sum_{i=1}^{N_{C}} C_{C}\left(D_{i}\right) \cdot L_{i}+\sum_{j=1}^{N_{T}} C_{T}\left(V_{j}\right)+\sum_{k=1}^{N_{N}} C_{I}\left(y_{k}\right) \cdot A_{k}
$$

Where, $N_{c}$ represents the total number of conduits in the network, $N_{N}$ represents the total number of nodes in the network and $N_{T}$ represents the total number of storm tanks installed in the network.

\section{Multi-objective optimization}

In this part of the methodology, the objective is to minimize two conflictive objective functions. The first represents the investment costs and the second represents the flood damage costs. These functions are linked such that if more investments are made, flood damage costs will be reduced and reciprocally.

The Equation (5) represents the investments costs $\left(F_{l}\right)$ composed of pipes substitution costs and storm tanks installation costs. While Equation (6) represents the flood damage costs. The two objective functions express hydraulic values in monetary units as presented in the hypothesis of the work. 


$$
\begin{gathered}
F_{1}=\sum_{i=1}^{N_{C}} C_{C}\left(D_{i}\right) \cdot L_{i}+\sum_{j=1}^{N_{T}} C_{T}\left(V_{j}\right) \\
F_{2}=\sum_{k=1}^{N_{N}} C_{I}\left(y_{k}\right) \cdot A_{k}
\end{gathered}
$$

In Equations (5) and (6) $N_{C}$ represents the total number of conduits in the network, $N_{N}$ represents the total number of nodes in the network and $N_{T}$ represents the total number of storm tanks installed in the network.

\section{V.3. Methodology}

The proposed methodology of this work is composed of two complementary parts that together form a complete drainage network optimal rehabilitation methodology. The first part called Search space reduction allows to reduce the number of decision variables of the addressed problem consequently; the problem size is reduced. Once the problem size is reduced, if an optimization is applied to this search space reduction model, the computation time will be reduced due to the reduction of local minima, this will result in the obtention of better results respectively to the optimization of the complete model. The second part is the application of a multiobjective evolutionary algorithm that can be applied to any drainage network. The aim of this part is the optimization of the new model obtained from the problem size reduction. The flow chart of the proposed methodology is presented on Figure 1. 


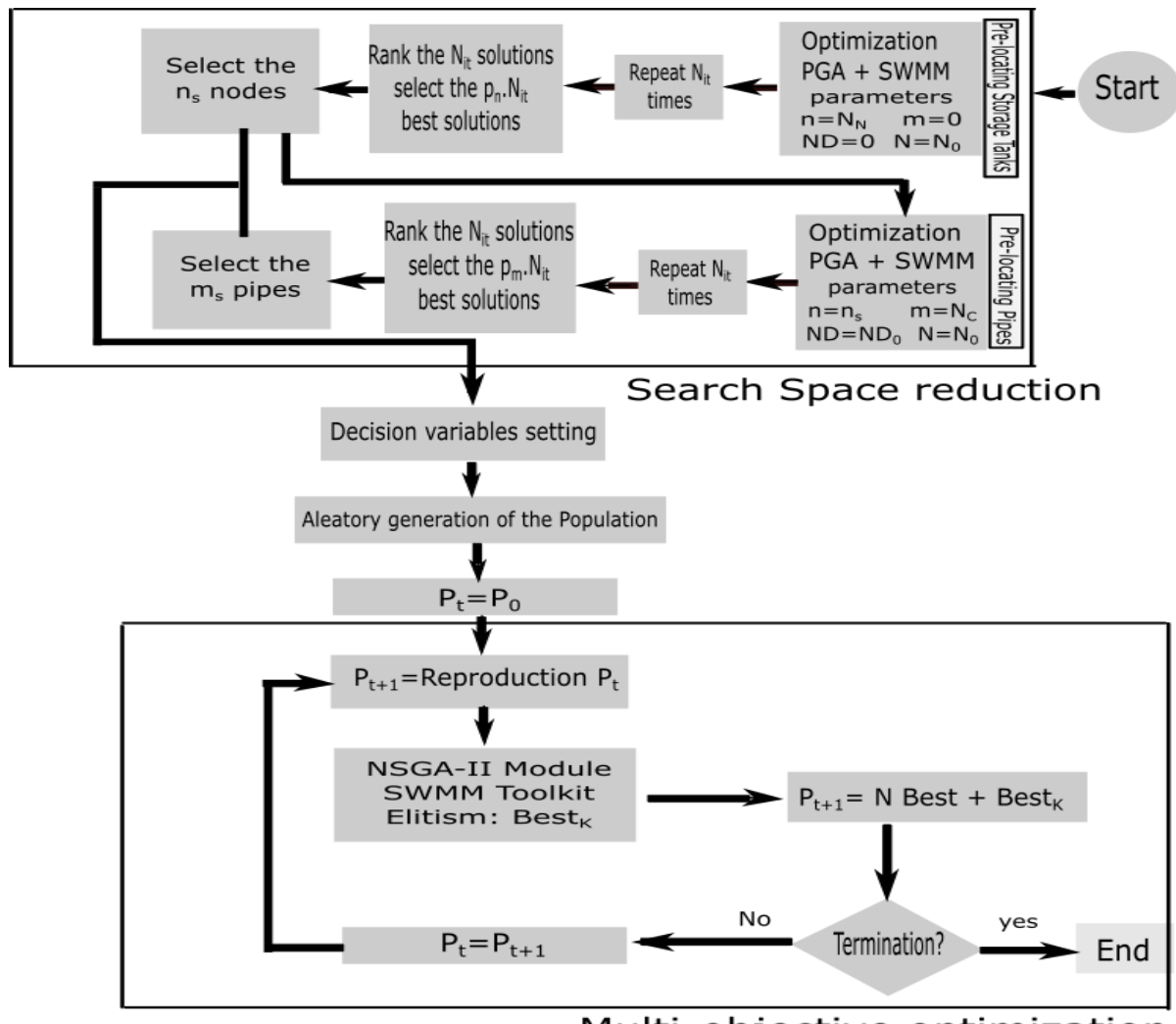

Multi-objective optimization

Figure 1. Flow Chart of the presented methodology.

The first part of the methodology proposed on Figure 1 presents two steps. The first one is the pre-location of nodes where storm tanks can be installed. The second step is the pre-selection of lines where pipes could probably be substituted. After the application of those two steps to a complete model of drainage network rehabilitation, a new model of reduced problem size is obtained. This new model goes through a multiobjective optimization described in the second part of the methodology.

Flood damages depend on the rainfall probability, so they cannot be well known in advance. In the first step of the methodology, two types of costs are used in the objective function: construction costs that are real costs and flood damage costs that are futuristic costs. These two types of costs are conflicting in this situation. On the one hand, construction costs are increasing while on the other hand, flood damage costs are decreasing and vice versa. One of the best ways to harmonize both types of costs is to introduce a multi-objective evolutionary algorithm connected to a mathematical model 
of the drainage network. The second part of the proposed methodology will consist of the application of a multi-objective optimization algorithm to the reduced problem size obtained in the part one and a comparison of the obtained results with those of the whole problem optimization will be performed.

\section{V.3.1. Search space reduction: Single objective function}

This part of the methodology is presented on the top of Figure 1. The aim of this part of the proposed methodology is to reduce the search space of the problem. Decision variables are gradually eliminated to finally form a new rehabilitation scenario. Additionally, the obtained results found by the PGA are better than those obtained when the entire search space was used. The different options implemented in this part of the methodology to reduce the problem size include the following:

- Reduce the number of decision variables (nodes where storm tanks can potentially be installed and lines in which there could potentially be a change in diameter).

- Reduce the variation range of decision variables (Discretization in the storm tanks dimensioning and reduction of the candidate diameters that can be selected).

\section{Pre-locating storm tanks}

The first step of this part of the proposed methodology is the pre-location of storm tank. To achieve it, some $N_{i t}$ simulations are performed with all the nodes of the network $\left(n=N_{N}\right)$ considering their cross section (S) as decision variable The storm tanks to be installed are discretized in $N=N_{0}$ divisions aiming to reduce solution space, for the optimization with PGA. For this optimization process, the diameters are not included $(m=0)$. This means that there is not pipe renewing in this step.

After these simulations, obtained solutions are ranked from the best to the worst objective function value of Equation (4). A percentage $p_{n}$ of the best solutions is selected. An analysis of these solutions allows creating a list of $n_{s}$ possible storm tanks locations. In fact, these nodes are locations where storm tanks can be installed during the rehabilitation of the network. These nodes are considered because they are repeated locations of a storm tank installation within all the $p_{n}$ selected solutions.

\section{Locating lines of possible pipes substitutions}

The second step of this part of the proposed methodology is the pre-selection of pipes to be substituted. To achieve it, some $N_{i t}$ simulations are performed considering the $n_{s}$ selected nodes cross sections combined with all the pipes $\left(\mathrm{m}=N_{C}\right)$ of the network as decision variables. To ensure solution space reduction, storm tanks to be installed are discretized in $N=N_{0}$ divisions while number of candidate pipes diameters is $N D=N D_{0}$. 
After the simulations, obtained solutions are also ranked from the best to the worst objective function value of Equation (4). A percentage $p_{m}$ of the best solution is selected. An analysis of these solutions allows also creating a list of $\mathrm{m}_{\mathrm{s}}$ possible pipes to be substituted locations. These pipes are located where substitution can occur if the network is rehabilitated. These nodes are selected because they are repeated locations of a pipe substitution within all the $p_{m}$ selected solutions.

\section{V.3.2. Multi-objective Optimization: Optimization Algorithm}

After the obtention of search space reduction model, a multi-objective evolutionary algorithm is applied to this model and the obtained results are analyzed. Two important key elements are considered: The best result in term of Pareto front and the smallest simulation time. This part of the methodology is presented on the bottom of Figure 1.

Deb et al. [29] introduced NSGA-II which is a one of the most popular multiobjective evolutionary algorithm. NSGA-II has been implemented in various domains to solve real world problems. In this work, an additional elitism aspect has been added consisting for each generation in the selection of the best individual and the zeroinvestment individual, to be part of the next generation. The stop condition adopted in the methodology is the best values of the objective function of Equations (5) and (6). If after a certain number of generations there is no improvement in their values, the optimization process stops. The standard deviation of crowding distance aims to ensure the equally distribution of the Pareto front solutions. If the standard deviation is smaller, better would be the solution.

\section{V.4. Case Study}

In order to test the methodology mentioned above, a sub-catchment of the drainage network of Medellin city (Colombia) was used. The part of the drainage network studied is generically known as Ayurá district. The drainage network finally flows into the Medellín River, which cross the city from South to North. The network is extended over 22.5 ha and is divided into 83 hydrological sub-catchments for 73 nodes and 86 circulars conduits from 200 to $1050 \mathrm{~mm}$ diameters. The difference between the highest point and the lowest point of the network is $15.61 \mathrm{~m}$. The network works completely by gravity, since the terrain profile is favorable to the drainage of rainwater. The methodology has been applied to various networks, but Ayurá has been selected for this paper due to the elevated number of conduits and nodes and to the fact that Ayurá is a mesh network. Figure 2 presents Ayurá network. 


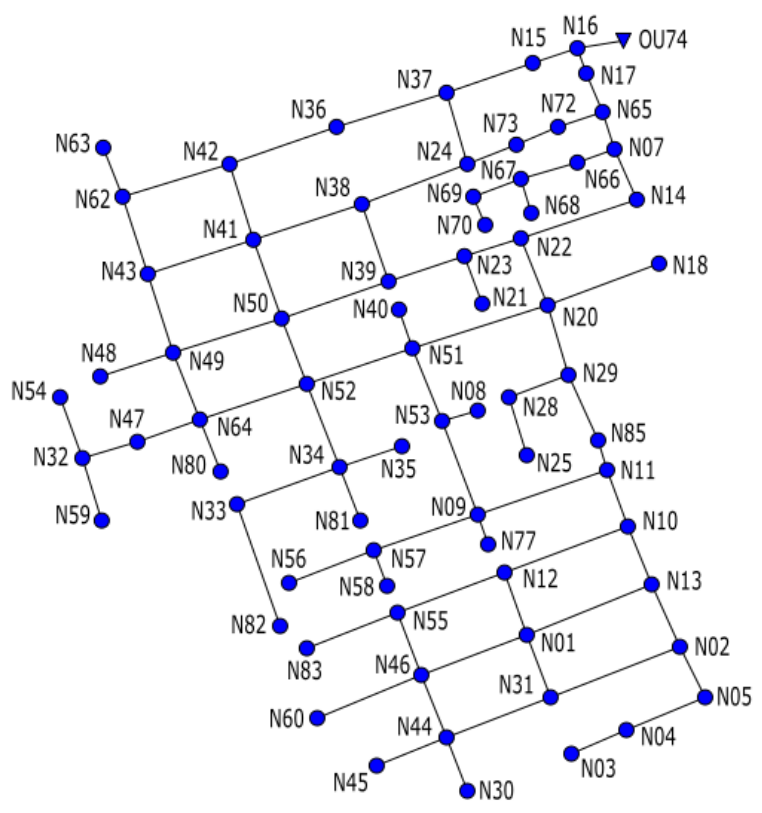

Figure 2. Representation of Ayurá drainage network.

From the first hydraulic analysis performed in SWMM, the total flooding volume of the network is about $4,271 \mathrm{~m}^{3}$ which represents $27.14 \%$ of the generated runoff $\left(15,735 \mathrm{~m}^{3}\right)$ from the selected rainfall. The IDF curve of the project rain is presented on Figure 3.

To sum up, the preliminary analysis of the network shows that it is unable to drain the selected project rain. Therefore, Ayurá drainage network was considered adequate to apply the proposed rehabilitation methodology of this work. 


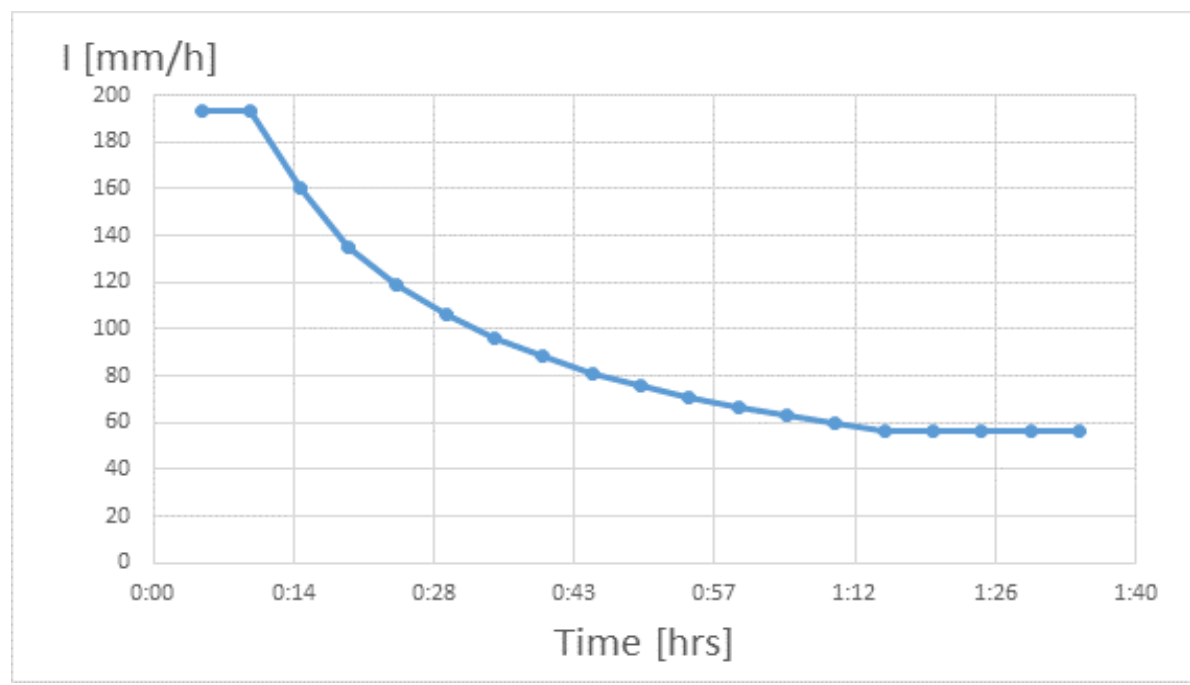

Figure 3. IDF Curve of the actual project rain.

Any simulation is only possible after the definition of all the data in the expression of the objective functions. Basically, this means define the following parameters; $\mathrm{A}$ and $\mathrm{B}$ of Equation (1) and $\mathrm{C}_{\min }, \mathrm{C}_{\mathrm{var}}$ and $n$ of Equation (2). The values considered are price databases established for the area where the network is located (Colombia). These values are shown in Table 2.

Table 2. Coefficients for pipes and storm tanks cost curves.

\begin{tabular}{ccccc}
\hline A & B & Cmin & Cvar & $n$ \\
40.69 & 208.06 & 16923 & 318.4 & 0.65 \\
\hline
\end{tabular}

Table 3 presents the full range of pipe diameters (D) and respective installation cost $(\mathrm{C})$ of each diameter. There are $N D=N D_{\max }=25$ parameters considering the 24 probable diameters than can be installed and the state corresponding to no taken action on the original pipe. Application of parameters of Table 2 to Equation (1) allows obtaining the different installation costs of commercial diameters. 
Table 3. Full range $\left(N D=N D_{\max }\right)$ of commercial diameters used in the example.

\begin{tabular}{ccccccccc}
\hline$D(\mathrm{~mm})$ & 300 & 350 & 400 & 450 & 500 & 600 & 700 & 800 \\
$C(€ / \mathrm{m})$ & 30.93 & 39.73 & 49.56 & 60.44 & 72.36 & 99.31 & 130.43 & 165.71 \\
\hline$D(\mathrm{~mm})$ & 900 & 1000 & 1100 & 1200 & 1300 & 1400 & 1500 & 1600 \\
$C(\epsilon / \mathrm{m})$ & 205.15 & 248.75 & 296.51 & 348.43 & 404.51 & 464.76 & 529.16 & 597.73 \\
\hline$D(\mathrm{~mm})$ & 1800 & 1900 & 2000 & 2200 & 2400 & 2600 & 2800 & 3000 \\
$C(\epsilon / \mathrm{m})$ & 747.35 & 828.4 & 913.61 & 1096.52 & 1296.07 & 1512.27 & 1745.11 & 1994.6 \\
\hline
\end{tabular}

The first rehabilitation process has been performed to the whole network, considering as decision variables all the 73 nodes and all the 86 lines, specifically define as:

Complete Model: Rehabilitation of the network combining the installation of conduits and storm tanks. The total number of decision variables is 159 .

The complete model is reduced after the application of the search space reduction (SSR) methodology and various search space reduction models can be obtained based on the selection probability.

Search space reduction model 1 for $10 \%$ selection probability: The number of conduit and node where action can be taken is reduced.

Search space reduction model 2 for $5 \%$ selection probability: The number of conduit and node where action can be taken is reduced.

Another selected probability will give another Search space reduction model.

\section{V.5. Results}

\section{V.5.1. Application of the search space reduction methodology to Ayurá: Single- objective}

The application of the first part (Search space reduction) of the proposed methodology (Figure 1) to the Ayurá network starts with the process of pre-locating Storm tanks. The parameters considered in this process are defined as:

- The number of simulations defined is hundred $\left(N_{i t}=100\right)$.

- The discretization of the storm tanks area is reduced to its minimum value $(N=$ $N_{0}=10$ ).

- Only the sections of the tanks potentially to be installed in the nodes of the network are considered as Decision Variables $\left(n=N_{N}=73\right)$.

- Conduits are not decision variables during the process $(m=0)$.

- The basic parameters of the PGA algorithm, population size $\left(N_{\text {pop }}=200\right)$ and the stopping criterion based on a number of generations $\left(N_{g e n}\right)$ without change, is fixed at 100 . 
After the obtention of all the simulations results, there are ranked and the percentage of $p_{n}$ best solutions in terms of objective function value is selected. This corresponds to the selection of 10 best solutions. It is analyzed for each solution in which nodes a storm tank has to be installed. At the end of this analysis, a list of storm tanks pre-location in the network is created. This analysis for Ayurá provides a list of 29 possible locations of storm tanks represented on Figure 4.

\begin{tabular}{|c|c|c|c|c|c|c|c|c|c|c|c|}
\hline N01 N02 N03 & N04 & N05 & N07 & N08 & N09 & N10 & N11 N12 & N13 & N14 & N15 & N16 \\
\hline N17 N18 N20 & N21 & N22 & N23 & N24 & N25 & N28 & $\mathrm{N} 29 \mathrm{~N}$ & - & N32 & N33 & N34 \\
\hline V35 N36 I & N38 & N39 & 0 & N41 & N42 & N43 & N44 & N46 & N47 & N48 & N49 \\
\hline J50 N51 & N53 & N54 & 55 & N56 & N57 & N58 & 60 & N62 & N63 & N64 & N65 \\
\hline J66 N67 N68 & V69 & J70 & N72 & N73 & N77 & N80 & N81 N8 & N83 & N85 & & \\
\hline
\end{tabular}

Figure 4. Selected nodes (Green Color) as storm tanks pre-location

The second step of the first part (search space reduction) of the proposed methodology (Figure 1) is the pre-selection of conduits. For this, the pre-locations of storm tanks are used and combined with all the conduits to perform simulations. A reduction in the number of potentially substitutable pipes is sought. The parameters considered in this process are defined as:

- The number of simulations is the same as in the previous stage $\left(N_{i t}=100\right)$.

- The decision variables are the areas of the $(\mathrm{ns}=29)$ selected nodes of the first step and the diameters of all the conduits $\left(n=N_{C}=86\right)$ of the network.

- The discretization of the area of the storm tanks is kept at the minimum value, as it happened with the previous step of the process.

- The basic parameters of the PGA algorithm are the same as in the previous phase $\left(N_{\text {pop }}=200, \mathrm{~N}_{\text {gen }}=100\right)$.

- A range of reduced diameters is used instead of the full range of diameters of Table 3. The new set of the used diameters (D) and their installation costs (C) in this case are presented in Table 4. There are $N D=N D_{0}=10$ parameters considering the 9 probable diameters that can be installed and the state corresponding to no taken action on the original pipe. Application of parameters of Table 2 to Equation (1) allows also obtaining the different installation costs of commercial diameters presented in Table 4.

Table 4. Reduced diameter range $\left(N D=N D_{0}=10\right)$

\begin{tabular}{rrrrrrrrrr}
\hline $\mathrm{D}(\mathrm{mm})$ & 300 & 400 & 600 & 800 & 1000 & 1200 & 1500 & 1800 & 2000 \\
$\mathrm{C}(€ / \mathrm{m})$ & 30.93 & 49.56 & 99.31 & 165.7 & 248.74 & 348.43 & 529.16 & 747.35 & 913.61 \\
\hline
\end{tabular}


After the obtention of all the simulations results, they are ranked and the percentage of $p_{m}$ best solutions in term of objective function value is selected. In this work, two different conduits pre-selections have been settled. The first considers a probability of $10 \%$ of the best solutions $\left(p_{m l}=10 \%\right)$ and the second considers only a probability of $5 \%$ of the best solutions $\left(p_{m 2}=5 \%\right)$. The preselected lines in each case are shown on Figure 5 and Figure 6.

\begin{tabular}{|c|c|c|c|c|c|c|c|c|c|c|c|c|c|c|}
\hline P01 & P02 & P03 & P04 & P07 & P08 & P09 & P10 & P11 & P12 & P13 & P14 & P15 & P16 & P17 \\
\hline P18 & P19 & P20 & P21 & P22 & P23 & P25 & P26 & P27 & P28 & P29 & P31 & P32 & P33 & P34 \\
\hline P35 & P37 & P38 & P39 & P40 & P41 & P42 & P43 & P44 & P45 & P46 & P47 & P48 & P49 & P50 \\
\hline P51 & P52 & P53 & P54 & P55 & P56 & P57 & P58 & P59 & P60 & P61 & P62 & P63 & P64 & P65 \\
\hline P66 & P67 & P68 & P69 & P70 & P71 & P72 & P74 & P75 & P76 & P77 & P78 & P79 & P80 & P81 \\
\hline P83 & P84 & P85 & P86 & P87 & P88 & P89 & P90 & P91 & P92 & P94 & & & & \\
\hline
\end{tabular}

Figure 5. Selected lines (Green Color) to potentially be replaced for $p_{m l}=10 \%$.

\begin{tabular}{|c|c|c|c|c|c|c|c|c|c|c|c|c|c|}
\hline $\mathrm{JI}$ & 2 & 34 & P07 & 8 & 09 & P10 & 11 & 12 & P13 & 14 & 15 & 16 & r \\
\hline 18 & 20 & P21 & P22 & 3 & 5 & $\mathrm{P}$ & 27 & 28 & 9 & P31 & 32 & 33 & 1 \\
\hline & 38 & P39 & $P$ & 1 & 2 & 3 & & 45 & 46 & P47 & 48 & $\theta$ & 50 \\
\hline & & P54 & & & 7 & 8 & 9 & 50 & 61 & 2 & 3 & 64 & 65 \\
\hline & 58 & P69 & P70 & & 2 & & 5 & 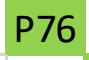 & P77 & I & 9 & 80 & P81 \\
\hline 32 & 35 & 86 & 7 & 38 & 89 & P90 & 91 & בר & P94 & & & & \\
\hline
\end{tabular}

Figure 6. Selected lines (Green Color) to potentially be replaced for $p_{m l}=5 \%$.

Finally, the conduits pre-selection process permits to select for $10 \%$ of the best solutions a total of 47 pipes and for $5 \%$ of the best solutions a total of 39 pipes. These data showing the reduction of the search space of the problem allow forming two new rehabilitation models that can go through a final optimization that is the final step of the first part (search space reduction) of the methodology or can go straight to the second part (Multi-objective) of the methodology. The two search space reduction models obtained are defined as follow:

- Search space reduction model 1: Rehabilitation of the network combining the possible installation of storm tanks on the 29 selected nodes and the 47 conduits that can be substituted. 
- Search space reduction model 2: Rehabilitation of the network combining the possible installation of storm tanks on the 29 selected nodes and the 39 conduits that can be substituted.

To validate that the search space reduction methodology improves the results in single-objective optimization, a single-objective optimization is applied to SSR model 1 and SSR model 2. The simple rehabilitation methodology is applied to complete model and the results are presented in Table 5 although this is not the objective of this work.

Table 5: Problem size reduction methodology: Ayurá single-objective optimization process

\begin{tabular}{ccccccccccc}
\hline \multirow{2}{*}{$\begin{array}{c}\text { Model } \\
\end{array}$} & \multicolumn{2}{c}{$\begin{array}{c}\text { No. Decisions } \\
\text { Variables }\end{array}$} & $\begin{array}{c}\text { Objective } \\
\text { Nodes }\end{array}$ & Lines & Function & Costs of the objective function & \multicolumn{2}{c}{$\begin{array}{c}\text { No. elements in } \\
\text { the solution }\end{array}$} & $\begin{array}{c}\text { Problem } \\
\text { size }\end{array}$ \\
\hline Complete & 73 & 86 & 381,950 & 6,335 & 215,828 & 159,787 & 5 & 33 & $7.8 \cdot 10^{122}$ \\
SSR1 & 29 & 47 & 351,879 & 3,983 & 215,769 & 132,127 & 5 & 33 & $1.9 \cdot 10^{100}$ \\
SSR2 & 29 & 39 & 347,982 & 3,541 & 244,288 & 100,153 & 6 & 27 & $1.8 \cdot 10^{98}$ \\
\hline
\end{tabular}

Table 5 presents the obtained results of single-objective optimization for complete model and search space reduction model 1 and search space reduction model 2. These results are used to validate that the search space reduction methodology helps to improve the single-objective optimization results although the main objective of this paper is a multi-objective optimization. It also shows how decreases the search space of the problem while reducing decision variables number. It can be observed that for singleobjective search space reduction models (SSR models 1 and 2) optimization provides better results than the complete model optimization.

\section{V.5.2. Application of Multi-objective evolutionary methodology to the reduced problem size of Ayurá: Multi-objective}

After the obtention of the new rehabilitation models, the problem size reduction part of the methodology is closed. The SSR 1 and SSR2 models undergo a multi-objective optimization through NSGA-II algorithm.

The obtained results of those SSR models are compared with the ones of the complete model. To achieve it, this complete model is also submitted to the same multi-objective optimization. The parameters considered in this process are defined as:

- Crossover probability is fixe at $80 \%$ for all the scenaries.

- Mutation coefficients are calculated as the inverse of the number of decision variables. 
- The discretization of the storm tanks area is fixed to its maximum value $(N=$ Nmax $=40$ ).

- The full range of diameters (Table 3$)$ is used. $\left(N D=N D_{\max }=25\right)$

- For all the scenarios, population size $\left(N_{p o p}=200\right)$ and $\left(\mathrm{N}_{\mathrm{gen}}=100\right)$.

- The number of simulations defined is hundred $\left(N_{i t}=100\right)$.

For this second part (Multi-objective) of the methodology, twenty simulations were run for each presented model. The simulation time varying between 2 and 14 days for the complete model (73T86C) depending on the configuration and between 1 and 7 days for SSR models 1 (29T47C) and 2 (29T39C) depending on the configuration. The complete model computation time is twice higher than the one of search space reduction models.

Figure 7 shows Pareto fronts of the 3 models with population 200 and number of generations 30000 for complete model and 15000 for SSR models 2 and 3. It can be observed that SSR models give better results than the complete model resolution.

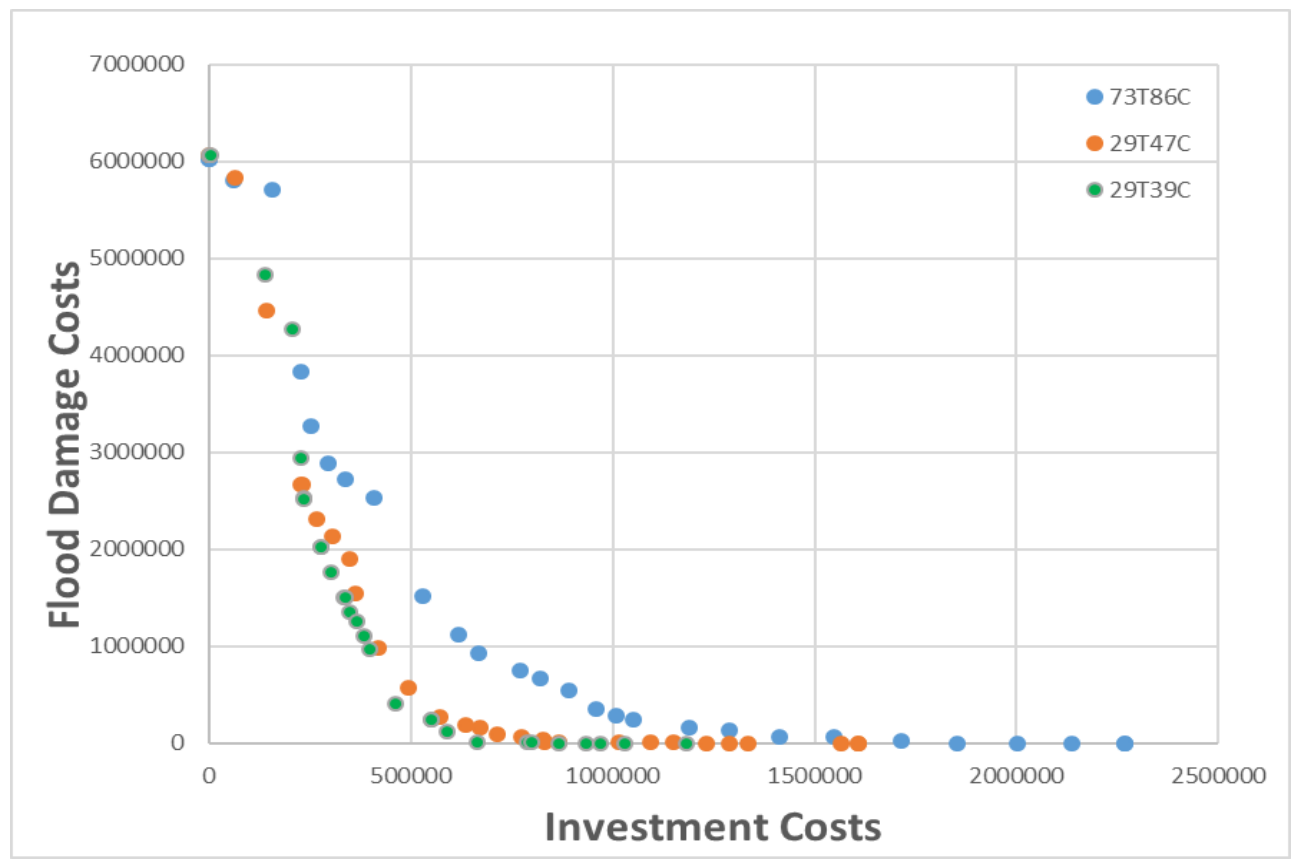

Figure 7. Pareto fronts representation of 3 different models.

The NSGA-II presents a set of feasible solutions instead of a single one. That is why the decision about the best solution depends on several factors such as budget availability, risk level, administrative regulations, etc. For this reason, a multi-objective algorithm was selected. As an example, the solution for the case of unlimited budget 
availability is presented. If there are no investment limitations, the solution will look for a model with no flooding. This scenario corresponds to the horizontal axis of Figure 7. The solution for zero-flooding needs an investment of $2,269,492 €$ for complete model or 1,607,890.49€ for reduced model 1 and 1,183,543.31€ for reduced model 2.

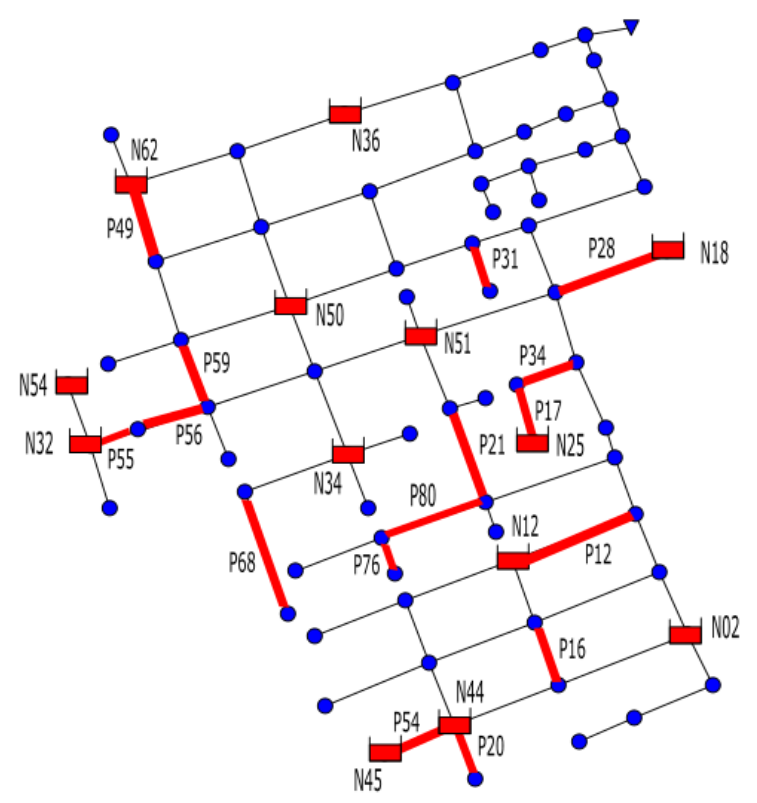

Figure 8. Representation of storm tanks installed and pipes to substitute according to model SSR 2 zero-flooding solution

Actions that should be taken for the zero-flooding solution of model SSR 2 are presented on Figure 8. Storm tanks to install locations and pipes to be substituted are presented.

Table 6 presents the list of pipes to be substituted for the zero-flooding solution of model SSR 2 and their corresponding diameters.

Table 6. New pipe diameters according to the zero-flooding solution of model SSR 2

\begin{tabular}{ccccccccc}
\hline Pipes & P12 & P16 & P17 & P20 & P21 & P28 & P31 & P34 \\
$\mathrm{D}(\mathrm{mm})$ & 300 & 350 & 600 & 600 & 300 & 3000 & 300 & 300 \\
\hline Pipes & P49 & P54 & P55 & P56 & P59 & P68 & P76 & P80 \\
D $(\mathrm{mm})$ & 350 & 3000 & 300 & 3000 & 300 & 350 & 400 & 350 \\
\hline
\end{tabular}


Table 7 presents the list of nodes where storm tanks should be installed and their corresponding base areas for the zero-flooding solution of model SSR 2.

Table 7. New storm tanks areas according to the zero-flooding solution of model SSR 2

\begin{tabular}{lccccccccccccc}
\hline Nodes & N02 & N12 & N18 & N25 & N32 & N34 & N36 & N44 & N45 & N50 & N51 & N54 & N62 \\
A(m2) & 1400 & 1450 & 450 & 1850 & 1250 & 150 & 1100 & 800 & 800 & 1450 & 650 & 100 & 250 \\
\hline
\end{tabular}

After the analysis of results obtained for the zero-flooding solution of model SSR 2 multi-objective optimization. The following observation was made: from the 16 pipes to replace, 13 pipes have an increase of diameters, while pipes P12, P55 and P80 diameters are smaller than the original ones. In these parts of the network, it is reasonable to install a dissipation element (an orifice or a gate) to introduce a head loss equivalent to the one that involves the installation of the new smaller diameter. This result shows the necessity to include the hydraulic control in drainage networks rehabilitation process.

To close this study, a last investigation has been made to see the effect of the number of generations on the result provided by the model SSR 2. Figure 9 shows Pareto fronts of SSR model 2 (29T39C) for 7 different maximum number of generations with a population of 200 individuals. It can clearly be observed that the 7 Pareto fronts overlap themselves each other. This means that with a low number of generations the reduced model can provide good results, allowing reducing the computation time.

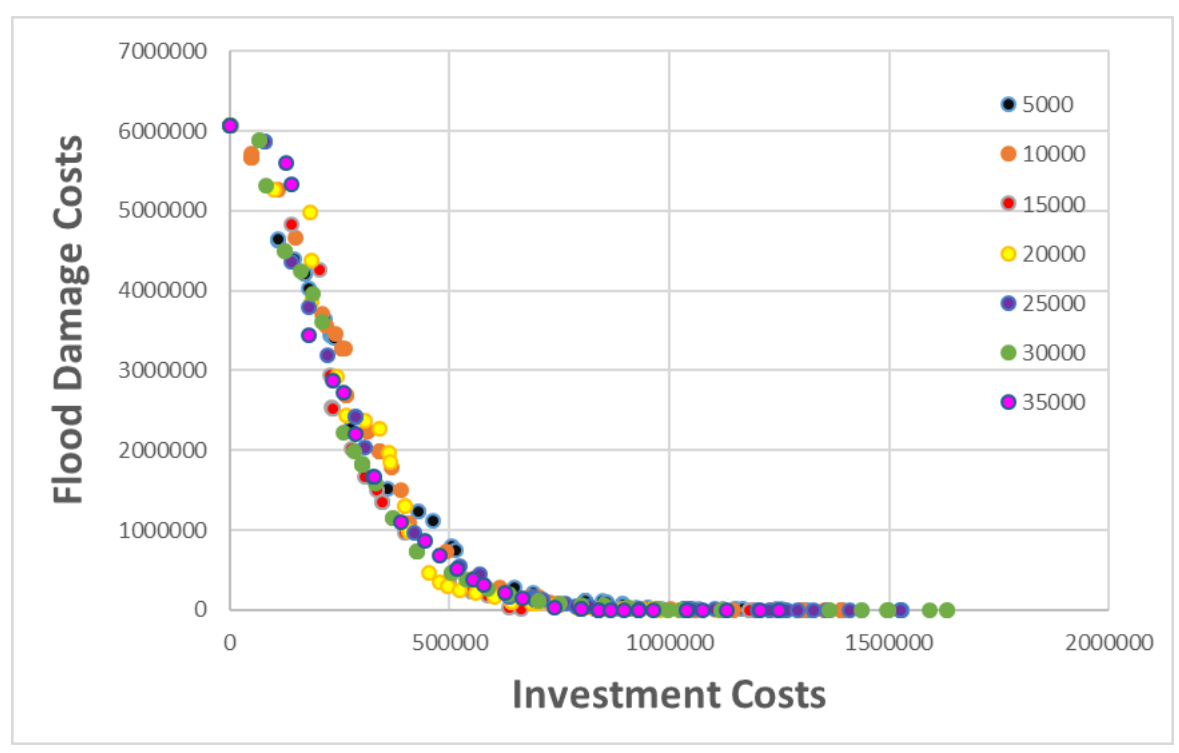

Figure 9. Pareto front representation of model SSR 2 (29T39C) and 7 different number of generations. 


\section{V.6. Discussion}

The application of the methodology to a real network permitted us to achieve the following results.

- The application of the search space reduction part of the methodology to the network called Ayurá allowed us to obtain two SSR models. SSR model 1 (29T47C) and SSR model 2 (29T39C).

- The application of the single-objective optimization given for the precedent SSR models better results than the application of the single-objective optimization to the complete model (73T86C). For these SSR models 1 and 2, the computation time is considerably reduced when compared to the complete model.

- The application of the second part of the methodology shows that Pareto fronts of SSR models 1 and 2 are better than the Pareto front of the complete model. This result is in accordance with the one provided by the single-objective optimization presented as a validation test of the SSR methodology.

- Computation time required to simulate a complete model is divided into two for SSR model 2, which passes from 14 days to 7 days. The number of generations for the two models is, respectively, 30,000 generations and 15,000 generations representing exactly the double. For the model SSR 2, 15,000 generations rather than 30,000 are used in this case because 10,000 generations objective function values do not improve.

- Representation of the SSR problem for different numbers of generations shows that it is not necessary for the use of an elevated number of generations to achieve good results.

Some results show that some conduits were substituted by smaller diameters. This shows the necessity to include hydraulic control in the rehabilitation process.

The efficiency of the methodology has been tested and it appears that, for scenarios considering search space reduction, a small population size can provide good results as a medium or large population size.

\section{V.7. Conclusions}

Extreme rainfall events and urbanization cause flooding problems to some originally well-designed drainage networks. One approach considers that these networks should be adapted to the new environmental and climatic conditions. Therefore, many strategies of adaptation have been planned and applied to solve the problem. Unfortunately, some of these strategies with time become ineffective due to climate change. Gong et al. [22] and Mora et al. [23] arrived at the conclusion that the green roof is inefficient for extreme rainfall events. It is important to always look for new and better strategies. Rehabilitation of drainage networks using pipes replacement and storm tank installations appears to be a better alternative to implement in order to effectively reduce 
or mitigate flooding. The problem encountered in this case is that the necessary time to implement such a solution is too elevated. In this work, an optimal rehabilitation methodology is presented. The methodology is composed by a search space reduction part, which reduces the problem size and a multi-objective part. This solves the search space reduction model based on the different defined objectives. The methodology implements key options to achieve the search space reduction. Reduction of search space reduces the number of local minima and calculation time. Reduction of search space achieves better results in both single-objective and multi-objective optimization.

The proposed methodology applied to the Ayurá network can be extended to any type of drainage network, since the methodology has been presented in a general form so that it can be easily extrapolated to other networks.

Drainage networks with pumping stations can be sources of uncertainties, but the presented methodology would be applicable. If the pumping station already exists in the network, the new decision variables can be the start and stop levels of the pump and the size of the suction tank. If the pumping station has to be installed in the drainage network, the flows to be evacuated by each pump would be defined as decision variables. The pumping investment costs should then be added in the objective function.

Search space reduction is an easy task to implement but, depending on the network size and the computer capacity, this operation may need more time. However, it is necessary to reduce the search space because it increases the exploration capacity of the optimization algorithm. The optimization of a search space reduction model provides better results (Figure 7) than the complete model and the computation time is considerably reduced.

The application of the proposed methodology to Ayurá, which is a mesh drainage network, shows the effectiveness and the robustness of the proposed methodology.

Address the rehabilitation in monetary units permits the assessment of the flood damages and selects the corresponding investments to mitigate them. Pareto fronts provided a set of optimal solutions that can help drainage managers to select the ones corresponding to their budget, the risk assessment, or the network design criteria.

In a context where time optimization is a new challenge in water resources management, this study shows that problem size reduction or search space reduction is important to save time and investments in the presence of an optimization problem. The SSR problem gives the smallest investments costs that reduce flood damage costs because the reduction of problem size allows a better exploration of the solution space for the optimization algorithm.

Results obtained for the zero-flooding solution of model SSR 2 show that it will be interesting to include some hydraulic dissipation elements such as orifices or gates during the rehabilitation process to operate the hydraulic control. 


\section{V.7. References}

1. Jeong, H., Ha, S., \& Kim, H. Flood Protection Cost Allocation Using Cooperative Game Theory for Adapting Infrastructure to Climate Change. J Water Resour Plan Manag 2018, vol. $144 \quad$ no. 4, pp. 04018010. https://doi.org/10.1061/(ASCE)WR.1943-5452.0000920

2. Quinn, A. D., Ferranti, E. J. S., Hodgkinson, S. P., Jack, A. C. R., Beckford, J., \& Dora, J. M. Adaptation Becoming Business as Usual: A Framework for ClimateChange-Ready Transport. Infrastructures 2018, vol. 3 no. 2, pp.10. https://doi.org/10.3390/infrastructures3020010

3. Szewrański, S., Chrusćinśki, J., Kazak, J., Swíader, M., Tokarczyk-Dorociak, K., \& Zmuda, R. Pluvial Flood Risk Assessment Tool (PFRA) for rainwater management and adaptation to climate change in newly urbanised areas. Water 2018, vol. 10 no. 4, pp. 386. https://doi.org/10.3390/w10040386

4. Silva, M. M., \& Costa, J. P. (2018). Urban floods and climate change adaptation: The potential of public space design when accommodating natural processes. Water 2018, vol. 10 no. 2, pp. 180. https://doi.org/10.3390/w10020180

5. Zhang, D., Martinez, N., Lindholm, G., \& Ratnaweera, H. Manage Sewer In-Line Storage Control Using Hydraulic Model and Recurrent Neural Network. Water Resour Manag 2018, vol. 32 no. 6, pp. 2079-2098. https://doi.org/10.1007/s11269-018-1919-3

6. Prasad, V., Kandasamy, V., Sinha, S. K., \& Asce, M. Stormwater Pipe Performance Index Using Fuzzy Inference Method. J Water Resour Plan Manag 2018, vol. 144 no. 10, pp. 04018062. https://doi.org/10.1061/(ASCE)WR.19435452.0000967

7. Song, Y. H., Yun, R., Lee, E. H., \& Lee, J. H. Predicting sedimentation in urban sewer conduits. Water 2018, vol. 10 no. 4, pp. 462. https://doi.org/10.3390/w10040462

8. Scionti, F., Miguez, M. G., Barbaro, G., De Sousa, M. M., Foti, G., \& Canale, C. Integrated Methodology for Urban Flood Risk Mitigation in Cittanova, Italy. $J$ Water Resour Plan Manag 2018, vol. 144 no. 10, pp. 05018013. https://doi.org/10.1061/(ASCE)WR.1943-5452.0000985

9. Kroll, S., Weemaes, M., Impe, J. Van, \& Willems, P. A Methodology for the Design of RTC Strategies for Combined Sewer Networks. Water 2018, vol. 10 no. 11, pp. 1675. https://doi.org/10.3390/w10111675

10. Vermuyten, E., Meert, P., Wolfs, V., \& Willems, P. Combining Model Predictive Control with a Reduced Genetic Algorithm for Real-Time Flood Control. J Water Resour Plan Manag 2018, vol. 144 no. 2, pp. 04017083. https://doi.org/10.1061/(ASCE)WR.1943-5452.0000859 
11. Salinas-Rodriguez, C., Gersonius, B., Zevenbergen, C., Serrano, D., \& Ashley, R. A semi risk-based approach for managing urban drainage systems under extreme rainfall. Water 2018, vol. 10 no. 4, pp. 384. https://doi.org/10.3390/w10040384

12. Caldas, A. M., Pissarra, T. C. T., Costa, R. C. A., Neto, F. C. R., Zanata, M., Parahyba, R. da B. V., Pacheco, F. A. L. Flood vulnerability, environmental land use conflicts, and conservation of soil and water: A study in the Batatais SP municipality, Brazil. Water 2018, vol. 10 no. 10, pp. 1357. https://doi.org/10.3390/w10101357

13. Alves, A., Gersonius, B., Sanchez, A., Vojinovic, Z., \& Kapelan, Z. Multi-criteria Approach for Selection of Green and Grey Infrastructure to Reduce Flood Risk and Increase CO-benefits. Water Resour Manag 2018, vol. 32 no. 7, pp. 25052522. https://doi.org/10.1007/s11269-018-1943-3

14. Kolen, B., \& van Gelder, P. H. A. J. M. Risk-based decision-making for evacuation in case of imminent threat of flooding. Water 2018, vol. 10 no. 10, pp. 1429. https://doi.org/10.3390/w10101429

15. Song, J. Y., Chung, E. S., \& Kim, S. H. Decision support system for the design and planning of low-impact development practices: The case of Seoul. Water 2018, vol. 10 no. 2, pp. 146. https://doi.org/10.3390/w10020146

16. De Paola, F., Giugni, \& M., Pugliese, \& F., Romano. Optimal Design of LIDs in Urban Stormwater Systems Using a Harmony-Search Decision Support System. Water Resour Manag 2018, vol. 32 no. 15, pp. 4933-4951. https://doi.org/10.1007/s11269-018-2064-8

17. Xiao, Q., McPherson, E., Zhang, Q., Ge, X., \& Dahlgren, R. Performance of Two Bioswales on Urban Runoff Management. Infrastructures 2017, vol. 2 no. 4, pp. 12. https://doi.org/10.3390/infrastructures 2040012

18. Martínez, C., Sanchez, A., Galindo, R., Mulugeta, A., Vojinovic, Z., \& Galvis, A. Configuring Green Infrastructure for Urban Runoff and Pollutant Reduction Using an Optimal Number of Units. Water 2018, vol. 10 no. 11, pp.1528. https://doi.org/10.3390/w10111528

19. Hu, M., Zhang, X., Siu, Y. L., Li, Y., Tanaka, K., Yang, H., \& Xu, Y. Flood mitigation by permeable pavements in Chinese sponge city construction. Water 2018, vol. 10 no. 2, pp. 172. https://doi.org/10.3390/w10020172

20. Leimgruber, J., Krebs, G., Camhy, D., \& Muschalla, D. Sensitivity of ModelBased Water Balance to Low Impact Development Parameters. Water 2018, vol. 10 no. 12, pp. 1838. https://doi.org/10.3390/w10121838

21. Gong, Y., Yin, D., Fang, X., \& Li, J. Factors affecting runoff retention performance of extensive green roofs. Water 2018, vol. 10 no. 9, pp. 1217. https://doi.org/10.3390/w10091217

22. Mora-Melià, D., López-Aburto, C. S., Ballesteros-Pérez, P., \& Muñoz-Velasco, P. Viability of green roofs as a flood mitigation element in the central region of Chile. Sustainability 2018, vol. 10 no. 4, pp. 1130. https://doi.org/10.3390/su10041130 
23. Vojinovic, Z., Sahlu, S., Torres, A. S., Seyoum, S. D., Anvarifar, F., Matungulu, H., Kapelan, Z. Multi-objective rehabilitation of urban drainage systems under uncertainties. $J$ Hydroinfo 2014, vol. 16 no. 5, pp. 1044-1061. https://doi.org/10.2166/hydro.2014.223

24. Lim, S., Ho, V. H., Lee, S. Y., Yoo, D. G., \& Kim, J. H. Determination of optimal location and capacity of detention facilities. Procedia Eng 2014, Vol. 70, pp. 1037-1045. https://doi.org/10.1016/j.proeng.2014.02.115

25. Xu, K., Bin, L., Lian, J., \& Liu, R. Staged optimization design for updating urban drainage systems in a City of China. Water 2018, vol. 10 no. 1, pp. 66. https://doi.org/10.3390/w10010066

26. Yazdi, J. Rehabilitation of Urban Drainage Systems Using a Resilience-Based Approach. Water Resour Manag 2018, vol. 32 no. 2, pp. 721-734. https://doi.org/10.1007/s11269-017-1835-y

27. Martínez, C., Sanchez, A., Toloh, B., \& Vojinovic, Z. Multi-objective Evaluation of Urban Drainage Networks Using a 1D/2D Flood Inundation Model. Water Resour Manag 2018, vol. 32 no. 13, pp. 4329-4343. https://doi.org/10.1007/s11269-018-2054-x

28. Ngamalieu-Nengoue, U. A., Iglesias-Rey, P. L., Martínez-Solano, F. J., MoraMeliá, D., \& Saldarriaga Valderrama, J. G. Urban Drainage Network Rehabilitation Considering Storm Tank Installation and Pipe Substitution. Water 2019, vol. 11 no. 3, pp. 515. https://doi.org/10.3390/w11030515

29. Deb, K., Pratap, A., Agarwal, S., \& Meyarivan, T. A fast and elitist multiobjective genetic algorithm: NSGA-II. IEEE Trans Evol Comput 2002. vol. 6, no. 2, pp. 182197.

30. Ngamalieu-Nengoue, U. A., Iglesias-Rey, P. L., Martínez-Solano, F. J. \& MoraMeliá, D. Multi-Objective Optimization for Urban Drainage or Sewer Networks Rehabilitation through Pipes Substitution and Storage Tanks Installation. Water 2019. vol. 11 , no. 5 , pp. 935

31. Maier, H. R., Kapelan, Z., Kasprzyk, J., Kollat, J., Matott, L. S., Cunha, M. C. \& Ostfeld, A. Evolutionary algorithms and other metaheuristics in water resources: Current status, research challenges and future directions. Environ Model Softw 2014, vol. 62, pp. 271-299.

32. Sophocleous, S., Savić, D., \& Kapelan, Z. Leak Localization in a Real Water Distribution Network Based on Search-Space Reduction. J Water Resour Plan Manag 2019, vol. 145 no. 7, pp. 04019024.

33. Wang, K. H., \& Altunkaynak, A. Comparative case study of rainfall-runoff modeling between SWMM and fuzzy logic approach. J Hydro Eng 2011, vol. 17 no. 2, pp. 283-291.

34. Rosa, D. J., Clausen, J. C., \& Dietz, M. E. Calibration and verification of SWMM for low impact development. J Amer Water Resour Asso 2015, vol. 51 no. 3, pp. 746-757. 
35. Granata, F., Gargano, R., \& de Marinis, G. Support vector regression for rainfallrunoff modeling in urban drainage: A comparison with the EPA's storm water management model. Water 2016, vol. 8 no. 3, pp. 69.

36. L., A., Rossman. Storm Water Management Model User's Manual. U.S. Environmental Protection Agency. Cincinnati, OH, 2015.

37. Cunha, M. C., Zeferino, J. A., Simões, N. E., \& Saldarriaga, J. G. Optimal location and sizing of storage units in a drainage system. Environ Model Softw 2016, vol. 83, pp. 155-166. https://doi.org/10.1016/j.envsoft.2016.05.015

38. Mora-Melia, D., Iglesias-Rey, P. L., Martinez-Solano, F. J., \& Ballesteros-Pérez, P. Efficiency of Evolutionary Algorithms in Water Network Pipe Sizing. Water Resour Manag 2015, vol. 29 no. 13, pp. 4817-4831. https://doi.org/10.1007/s11269-015-1092-x

39. Wang, Q., Zhou, Q., Lei, X., \& Savić, D. A. Comparison of Multiobjective Optimization Methods Applied to Urban Drainage Adaptation Problems. J Water Resour Plan Manag 2018, vol. 144 no. 11, pp. 04018070. https://doi.org/10.1061/(ASCE)WR.1943-5452.0000996

40. Lee, E. H., \& Kim, J. H. Development of resilience index based on flooding damage in urban areas. Water 2017, vol. 9 no. 6, pp. 428. https://doi.org/10.3390/w9060428 